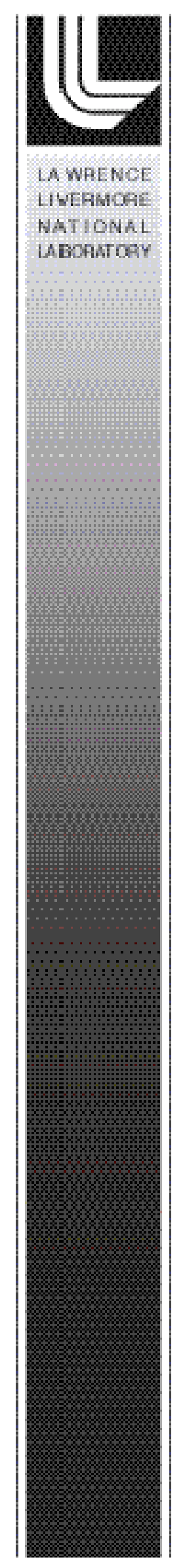

\title{
Modern Chemistry
}

Techniques Applied to Metal Behavior and Chelation in Medical and Environmental Systems - Final Report M. Sutton, B. Andresen, S. R. Burastero, M. L. Chiarappa-Zucca, S. Chinn, P. Coronado, A. E. Gash, J. Perkins, A. Sawvel, S. C. Szechenyi

February $14^{\text {th }}, 2005$ 
Disclaimer: This document was prepared as an account of work sponsored by an agency of the United States Government. Neither the United States Government nor the University of California nor any of their employees, makes any warranty, express or implied, or assumes any legal liability or responsibility for the accuracy, completeness, or usefulness of any information, apparatus, product, or process disclosed, or represents that its use would not infringe privately owned rights. Reference herein to any specific commercial product, process, or service by trade name, trademark, manufacturer, or otherwise, does not necessarily constitute or imply its endorsement, recommendation, or favoring by the United States Government or the University of California. The views and opinions of authors expressed herein do not necessarily state or reflect those of the United States Government or the University of California, and shall not be used for advertising or product endorsement purposes.

This work was performed under the auspices of the U. S. Department of Energy (DOE) by the University of California, Lawrence Livermore National Laboratory (LLNL) under Contract No. W-7405-Eng-48. The project (02-ERD-021) was funded by the Laboratory Directed Research and Development Program at LLNL. UCRL-TR-209476. 


\section{Modern Chemistry Techniques Applied to Metal Behavior and Chelation in Medical and Environmental Systems - Final Report}

M. Sutton, B. Andresen, S. R. Burastero, M. L. Chiarappa-Zucca, S. Chinn, P. Coronado, A. E. Gash, J. Perkins, A. Sawvel, S. C. Szechenyi

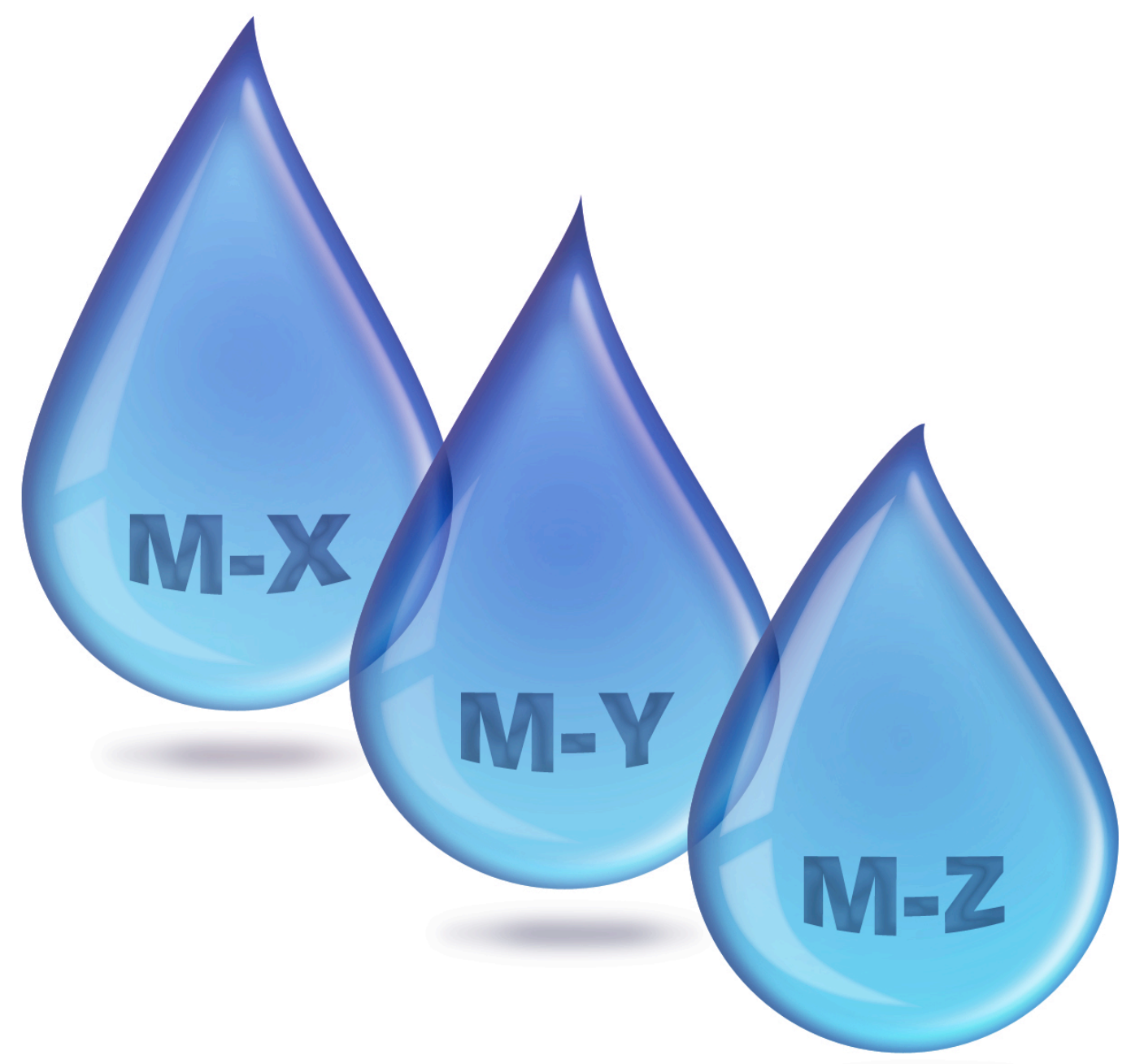

UCRL-TR-209476.

For more information, please contact Mark Sutton, L-231, Lawrence Livermore National Laboratory, 7000 East Avenue, Livermore, CA 94550.

Phone (925) 424-2137. Fax (925) 424-422-3160. Email sutton18@llnl.gov. 
M. Sutton, B. Andresen, S. R. Burastero, M. L. Chiarappa-Zucca, S. Chinn, P. Coronado, J. Perkins, A. Sawvel, S. C. Szechenyi

\section{Executive Summary:}

This report details the research and findings generated over the course of a 3-year research project funded by Lawrence Livermore National Laboratory (LLNL) Laboratory Directed Research and Development (LDRD). Originally tasked with studying beryllium chemistry and chelation for the treatment of Chronic Beryllium Disease and environmental remediation of beryllium-contaminated environments, this work has yielded results in beryllium and uranium solubility and speciation associated with toxicology; specific and effective chelation agents for beryllium, capable of lowering beryllium tissue burden and increasing urinary excretion in mice, and dissolution of beryllium contamination at LLNL Site $300 ;{ }^{9}$ Be NMR studies previously unstudied at LLNL; secondary ionization mass spec (SIMS) imaging of beryllium in spleen and lung tissue; beryllium interactions with aerogel/GAC material for environmental cleanup. The results show that chelator development using modern chemical techniques such as chemical thermodynamic modeling, was successful in identifying and utilizing tried and tested beryllium chelators for use in medical and environmental scenarios. Additionally, a study of uranium speciation in simulated biological fluids identified uranium species present in urine, gastric juice, pancreatic fluid, airway surface fluid, simulated lung fluid, bile, saliva, plasma, interstitial fluid and intracellular fluid. 
Executive Summary__ iv

Contents__ v

Tables \& Figures__vii

1. Introduction

1.1 Chemical Thermodynamic Modeling___ 2

1.2 Chronic Beryllium Disease___ 2

1.3 References__ 4

2. Beryllium Chemical Speciation in Elemental Human Biological Fluids__ 5

2.1 Method 6

2.2 Results and Discussion__ 11

2.3 Conclusions_ 25

2.4 References_ 26

3. Beryllium Chelation_ 28

3.1 Chemical Thermodynamic Modeling_ 29

3.1.1 Initial Screening_ 29

3.1.2 Structure and Functional Group Variation __

3.2 Toxicology_ 45

3.3 Synthesis_

3.4 Laboratory Experiments__ 50

$3.5{ }^{9}$ Be NMR

3.6 Animal Experiments _

3.7 SIMS Analysis__

3.8 Site-300 Beryllium Particle Dissolution Studies__

3.9 Structural Modeling_ $\quad 58$

4. Beryllium Interaction with Aerogel/GAC_

4.1 Introduction

4.2 Experimental Method_ 61

4.2.1 Preparation of the Aerogel/GAC Material___ 61

4.2.2 Physical Characterization_ 62

4.2.3 Balance and Pipette Certification_ 62

4.2.4 Potentiometric Titration of Aerogel/GAC Material___ 62

4.2.5 Analysis of Beryllium__ 63

4.2.6 Beryllium-Aerogel/G $\overline{A C ~ S o r p t i o n ~ I s o t h e r m s ~} 63$

4.2.7 Sorption pH Isotherms__ 63

4.2.8 Rate of Beryllium Sorption on Aerogel/GAC Material_63

4.3 Results and Discussion__ 64

4.3.1 Physical Characterization and Point of Zero Charge__ 64

4.3.2 Beryllium-Aerogel/GAC Sorption Isotherms___ 64

4.3.3 Rate of Beryllium Sorption__ 66 
4.3.4 pH Effects on Beryllium Sorption

4.4 Summary__ 68

4.5 References__ 69

5. Uranium(VI) Speciation and Solubility in Simulated Elemental

Human Biological Fluids___ 73

5.1 Introduction

5.2 Materials and Methods__

5.3 Results and Discussion_ 76

5.3.1 Intracellular and Extracellular Fluids___ 80

5.3.2 Saliva__ 83

5.3.3 Sweat__ 84

5.3.4 Pancreatic Fluid and Bile__

5.3.5 Gastric Juice___ 86

5.3.6 Urine_ 88

5.3.7 Lung / Airway Surface Fluid___ 89

5.4 Model Assumptions and Limitations___

5.5 Conclusions__ 92

5.6 References_

6. Conference Presentations, Papers and Reports Generated___ 96

Acknowledgements___ 98 
Tables and Figures:

Table 2-1 Elemental composition and pH of human intracellular, interstitial and plasma fluids

Table 2-2 Elemental composition and $\mathrm{pH}$ of human saliva 8

Table 2-3 Elemental composition and $\mathrm{pH}$ of human urine 8

Table 2-4 Elemental composition and $\mathrm{pH}$ of human sweat 9

Table 2-5 Elemental composition and pH of human gastric juice 9

Table 2-6 Elemental composition and pH of human pancreatic fluid 9

Table 2-7 Elemental composition and pH of human bile 10

Table 2-8 Elemental composition and pH of human ASF 10

Table 2-9 Percentage beryllium speciation at pH7 in airway surface fluid 24

Table 3-1. Literature and estimated lowest lethal dose $\left(\mathrm{LD}_{50}\right)$ 47

Table 3-2 Elemental composition of LLNL Site 300 CFF particles 57

Table 4-1 Physical and chemical properties of GAC and aerogel/GAC composite materials 64

Table 5-1 Summary of fluid $\mathbf{p H}$, modeled uranium speciation, solubility and precipitation 80

Table 5-2 Examples of urinary uranium concentrations relating to a variety of exposures 88 
Figure 1-1 Beryllium usage (2002) _ 3

Figure 1-2 Schematic of alveoli exposure to beryllium _ 3

Figure 2-1 Beryllium speciation with varying $\mathrm{pH}$ in the Be-OH system at $[\mathrm{Be}]=(\mathrm{a}) 1 \mu \mathrm{M}$ and $(\mathrm{b}) 1 \mathrm{mM}$

Figure 2-2 Beryllium speciation with varying $\mathrm{pH}$ in the $\mathrm{Be}-\mathrm{OH}-\mathrm{CO}_{3}$ system

Figure 2-3 Beryllium speciation in simulated intracellular fluid 13

Figure 2-4 Beryllium speciation in simulated interstitial fluid 14

Figure 2-5 Beryllium speciation in simulated plasma fluid 15

Figure 2-6 Beryllium speciation in simulated saliva 16

Figure 2-7 Beryllium speciation in simulated urine 17

Figure 2-8 Beryllium speciation in simulated sweat 18

Figure 2-9 Beryllium speciation in simulated gastric juice 19

Figure 2-10 Beryllium speciation in simulated pancreatic fluid 20

Figure 2-11 Beryllium speciation in simulated bile 21

Figure 2-12 Beryllium speciation in simulated simulated normal airway surface fluid 22

Figure 2-13 Beryllium speciation in simulated severe asthmatic airway surface fluid 23

Figure 2-14 Ionic strength effects on the solubility of $\mathrm{Be}(\mathrm{OH})_{2}$ in airway surface fluid

Figure 3-1 Effect of AcAc and pH on beryllium solubility in simulated interstitial fluid 30

Figure 3-2 AcAc speciation in interstitial fluid with added beryllium 30

Figure 3-3 Effect of APMDP and pH on beryllium solubility in simulated interstitial fluid 31 
Figure 3-4 APMDP speciation in interstitial fluid with added beryllium_ 31

Figure 3-5 Effect of CAS and pH on beryllium solubility in simulated Interstitial fluid

Figure 3-6 CAS speciation in interstitial fluid with added beryllium 32

Figure 3-7 Effect of catechol and pH on beryllium solubility in simulated interstitial fluid 33

Figure 3-8 Catechol speciation in interstitial fluid with added beryllium_ 33

Figure 3-9 Effect of DSNA and pH on beryllium solubility in simulated interstitial fluid 34

Figure 3-10 DSNA speciation in interstitial fluid with added beryllium 34

Figure 3-11 Effect of EDTA and pH on beryllium solubility in simulated interstitial fluid 35

Figure 3-12 EDTA speciation in interstitial fluid with added beryllium 35

Figure 3-13 Effect of histamine and pH on beryllium solubility in simulated interstitial fluid 36

Figure 3-14 Histamine speciation in interstitial fluid with added beryllium 36

Figure 3-15 Effect of hydroxyquinoline and pH on beryllium solubility in simulated interstitial fluid

Figure 3-16 Hydroxyquinoline speciation in interstitial fluid with added beryllium

Figure 3-17 Effect of salicylate and pH on beryllium solubility in simulated Interstitial fluid 38

Figure 3-18 Salicylate speciation in interstitial fluid with added beryllium_38

Figure 3-19 Effect of tiron and pH on beryllium solubility in simulated Interstitial fluid 39 
Figure 3-20 Tiron speciation in interstitial fluid with added beryllium 39

Figure 3-21 Diphosphonic acid structure and functional group variation 40

Figure 3-22 Effect of diphosphonic acid structure and functional group variation on chelator speciation and beryllium solubility

Figure 3-23 Effectiveness of methylene phosphonic acids in chelating beryllium

Figure 3-24 DSNA speciation in beryllium solutions with various isomers of DSNA

Figure 3-25 Toxicity estimate of APMDP based on known LD-50 data for phosphonic acid analogues 49

Figure 3-26 Schematic of APMDP synthesis 50

Figure 3-27 ${ }^{9}$ Be NMR spectra of $10 \mathrm{mM} \mathrm{BeSO}_{4}$ with $0.25 \mathrm{M} \mathrm{NaClO}_{4}$ over the pH range 2.0 - 12.0

Figure 3-28 ${ }^{9}$ Be NMR spectra of beryllium sulfate and chelator solutions at pH 12 52

Figure 3-29 ${ }^{9}$ Be NMR spectra of $5 \mathrm{mM} \mathrm{BeSO}_{4}$ with $2 \mathrm{mM}$ APMDP chelator over the $\mathrm{pH}$ range 2.5 - 11.8 53

Figure 3-30 Effect of APMDP chelator on the average beryllium tissue burden in mice after 72 hours 55

Figure 3-31 Effect of APMDP chelator on the average beryllium concentration in mouse blood after 72 hours 56

Figure 3-32 Effect of APMDP chelator on the average beryllium urinary excretion in mice 56

Figure 3.33 Be and Na SIMS analysis of mouse spleen 57

Figure 3.34 Effect of chelator concentration on Site 300 beryllium sample dissolution 58

Figure 3-35 Structural model of $\mathrm{Be}_{2} \mathrm{APMDP}$ 58

Figure 3-36 Structural model of Be(Tiron) 58 
Figure 4-1 Linear sorption isotherm for beryllium-aerogel/GAC material 66

Figure 4-2 Freundlich sorption isotherm for beryllium-aerogel/GAC material 66

Figure 4-3 Beryllium sorption onto aerogel/GAC material over time 67

Figure 4-4 Effect of pH on beryllium soption onto aerogel/GAC material 68

Figure 5-1 Uranium speciation and solubility with varying $\mathrm{pH}$ in the $\mathrm{U}(\mathrm{VI})-\mathrm{H}_{2} \mathrm{O}$ system 78

Figure 5-2 Uranium speciation and solubility with varying $\mathrm{pH}$ in the $\mathrm{U}(\mathrm{VI})-\mathrm{H}_{2} \mathrm{O}-\mathrm{CO}_{3}$ system 79

Figure 5-3 Uranium speciation and solubility with varying $\mathrm{pH}$ in simulated interstitial and plasma fluids 82

Figure 5-4 Uranium speciation and solubility with varying $\mathrm{pH}$ in simulated saliva 83

Figure 5-5 Uranium speciation and solubility with varying pH in simulated sweat 84

Figure 5-6 Uranium speciation and solubility with varying $\mathrm{pH}$ in simulated pancreatic fluid 85

Figure 5-7 Uranium speciation and solubility with varying pH in simulated bile 86

Figure 5-8 Uranium speciation and solubility with varying $\mathrm{pH}$ in simulated gastric juice 87

Figure 5-9 Uranium speciation and solubility with varying $\mathrm{pH}$ in simulated lung fluid 
1

\section{Introduction}




\section{Introduction}

\subsection{Chemical Thermodynamic Modeling}

Chemical thermodynamics is a physiochemical property based on the thermodynamic equations of mass and state, or in more general terms, on the difference between the free energy of a reaction product with respect to that of its reactants. A model of metal interactions is made based on data derived by experimental investigations by many researchers over many decades, and can allow a modeler to efficiently examine a number of chemical effects, such as $\mathrm{pH}$, ionic strength, concentration and alternative competing reactions.

For an equilibrium process in which species $\mathrm{A}^{+}$and $\mathrm{B}^{-}$react to give species $\mathrm{AB}$, a equilibrium constant can be derived for their respective chemical activities, which are in turn related to the chemical concentration of $\mathrm{A}$ and $\mathrm{B}$ :

$$
\mathrm{aA}^{\mathrm{n}+}+\mathrm{bB}^{\mathrm{n}-}=\mathrm{A}_{\mathrm{a}} \mathrm{B}_{\mathrm{b}} \quad(1) \quad \mathrm{K}_{\mathrm{f}}=\frac{\left\{\mathrm{A}_{\mathrm{a}} \mathrm{B}_{\mathrm{b}}\right\}}{\left\{\mathrm{A}^{\mathrm{n}}\right\}^{\mathrm{a}}\left\{\mathrm{B}^{\mathrm{n}-}\right\}^{\mathrm{b}}}
$$

Because the numerical values for such constants often vary over such a wide range, a logarithmic scale is used and values are often quoted as $\log \mathrm{K}_{\mathrm{f}}$, which in turn can be related to the change in the standard Gibbs free energy during the reaction $\left(\Delta \mathrm{G}^{\circ}\right)$ and temperature ( $\mathrm{T}$, kelvin) using the molar gas constant as seen in equation (3)

$$
\Delta \mathrm{G}^{\mathrm{o}}=-\mathrm{RT} \ln \mathrm{K}_{\mathrm{f}}
$$

Critically assessed and peer-reviewed chemical thermodynamic data have been assessed and published for many years (e.g. Smith and Martell (8)). More recently, such data has been transferred to a computer database to allow faster searches for required critical thermodynamic data (9) and it is the responsibility of the modeler to assure the highest possible quality of the data and the model can only be as good as the input data (10). Such chemical thermodynamic data has been used for many years in conjunction with geochemical codes such as MINTEQA2v4 (11) to predict and understand the chemistry of geological systems such as ground water and nuclear waste disposal. However, such a code can also be used to produce models of elemental biochemical environments.

\subsection{Chronic Beryllium Disease (CBD)}

Beryllium is used in many industries in a variety of forms - most commonly metal, oxides and alloys for the manufacture of materials ranging from nuclear components and electronics to golf clubs and aircraft brakes. Like most metals, beryllium oxidizes ('ages') in air to form a surface oxide layer. The thickness of the oxide layer on respirable particles of beryllium metal (particle diameters in the micrometer range) has been found to average approximately $5 \mathrm{~nm}$ (1). Studies with solid specimens of beryllium metal have shown that the oxide surface forms quickly ( $1 \mathrm{~nm}$ within minutes) and increases slowly with time ( $2.5 \mathrm{~nm}$ after 2.3 years) when exposed to ambient air at room temperature (2). 
Of course, the presence of additional oxidizing environments, be it chemical, physical or biological can alter the rate of oxidation.

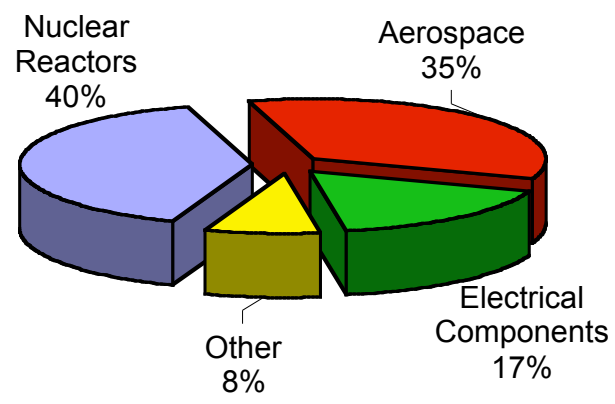

Figure 1-1. Beryllium usage (2002)

Beryllium itself resides in Group II of the periodic table, aligning itself with magnesium and calcium, yet its chemistry is closer to that of aluminum (group III) than its peers. It exhibits a "diagonal relationship" due to its small size (ionic radius: $0.31 \mathrm{~nm}(3)$ ), high affinity for electrons and ability to make four covalent bonds. Like aluminum, beryllium is also amphoteric, i.e. it reacts with both acids and bases to form a mixture of positively and negatively charged species. It also reacts chemically with components in biological fluids.

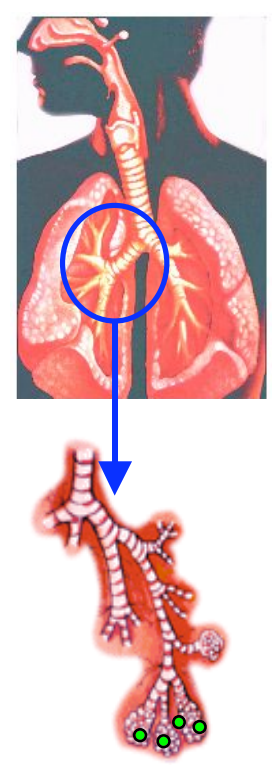

During the machining of beryllium parts, a range of beryllium particle sizes may be dispersed and pose a threat to worker health. When inhaled, the beryllium particles are taken into the lungs and trapped in the alveoli (Figure 1-2, left). A cohort of beryllium workers from the Rocky Flats site with CBD have shown evidence of beryllium in granulomatous tissue (4) and it is felt that such particles can contribute to a lung burden of beryllium, which can slowly dissolve to provide an immunologic challenge to the lungs $(4,5)$. Once in the lung tissue, the beryllium particles trigger the cell-mediated immune response, resulting in lymphocytic inflammation and eventually granulomatous lung scarring, termed Chronic Beryllium Disease (CBD). It is felt that beryllium retention in the lung plays a key role in this process (6). The current treatment for CBD is Prednisone, which acts to inhibit the inflammatory and immune response to beryllium. However, the use of such treatment is also associated with side effects including susceptibility to infections, water retention and loss of bone density. Chelation therapy could eventually provide an alternative or adjunctive treatment for the removal of a beryllium lung burden, therefore reducing immunologic challenge by beryllium, beryllium-related lymphocyte proliferation and potentially slowing the development of CBD (5). The goal of chelation therapy of metals is to selectively bind with the toxic metal ion and excrete the metal-chelate complex from the body. Ideally, this would be performed selectively such that only the toxic metal is bound while leaving other essential metals intact. 


\subsection{References}

1. Hoover, M. D., Castorina, B.T., Finch, G. L. and Rothenberg, S. J. (1988) Determination of the oxide layer thickness on beryllium metal particles. Am. Ind. Hyg. Assoc. J. 50, 550-553.

2. Musket, R. G. (1999) Oxidation of beryllium in ambient air. LLNL Report UCRL-JC-136563.

3. Lee, J. D. (1991) Concise Inorganic Chemistry, 4th Ed. pp.330-333. Chapman \& Hall, London.

4. Newman, L. (2002) Personal Communication, June.

5. Eisenbud, M. \& Guilmette, R. A (2000) Is there a role for chelation in the management of chronic beryllium disease? Technology, 7, 213-222.

6. Sprince, N. L., Kazemi, H., Hardy, L. (1976) Current problems of differentiating between beryllium disease and sarcoidosis. Ann. NY Acad. Sci., 278, 654-664.

7. Longcope, W. T., Freiman, D. G. (1952) A study of sarcoidosis. Medicine 31, 1-132.

8. Smith, R. M. and Martell, A. E. (1982) Critical Stability Constants, vol.5. Plenum Press, New York.

9. Motekaitis, R. J. (2001) NIST Standard Reference Database 46 ver.6. - NIST Critically Selected Stability Constants of Metal Complexes (Martell, A. E. and Smith, R. M., Eds).

10. Spahiu, K. (2002) Phase II of the NEA TDB Project and Some Lessons Learned from the Use of Phase I Data. In The Use of Thermodynamic Databases in Performance Assessment - Workshop Proceedings. NEA-OECD, Paris, France.

11. Allison, J. D., Novo-Gradac, K. J. and Brown, D. S.(1998) MINTEQA2 ver.4. - A Geochemical Assessment Model for Environmental Systems. Environmental Research Laboratory, Office of Research \& Development, United States Environmental Protection Agency, Athens, Georgia. 
2

\section{Beryllium Chemical Speciation in Elemental Human Biological Fluids}




\section{Beryllium Chemical Speciation in Elemental Human Biological Fluids}

In order to understand the chemistry of an effective beryllium chelator, it is also crucial to first understand the chemistry and distribution of beryllium in body fluids. This is of key importance not only to understanding the physiologic environments beryllium will encounter during and after exposure, but also in understanding the chemical effects that might affect the stability and efficiency of beryllium chelation and excretion. In addition, the work provides potentially useful knowledge in the development of techniques for metal bioassay in blood or urine as a surrogate measurement of human exposure, an area recently studied by some researchers (7).

The speciation of beryllium very much defines its potential distribution in the body. For example, at acidic $\mathrm{pH}$ or in environments with low concentrations of counter-ion, beryllium forms cations, while in neutral to alkaline $\mathrm{pH}$ and in environments with high concentrations of counter-ion, beryllium forms neutral species and anions. Clearly, cations will adsorb to net negative surfaces or biological binding sites such as bone, while anions will adsorb to net positive surfaces (for example eosinophil cationic protein, known to be important in the human immune response system).

\subsection{Method}

The elemental composition of human body fluids and tissues has been summarized by Iyengar et al (12) and standard physiology textbooks such as Guyton \& Hall (13). From this source, the elemental constituents of 9 types of human biological fluids (intracellular fluid, interstitial fluid, plasma water, saliva, sweat, urine, bile, gastric juice and pancreatic fluid) were recalculated based upon the weighted mean elemental composition. In cases where the number of samples in the reviewed analysis was unknown, a single sample was assumed to limit the uncertainty. The recalculated weighted mean concentrations of the body fluids used are detailed in Tables 2-1 through 2-7.

The work by Joris et al (17) presents investigations of the elemental composition of airway surface fluids (ASF) that form a $15-30 \mu \mathrm{m}$ coating on the surface of the conducting airways in a number of clinical cases as reported by other authors such as Matthews and Potter $(18,19)$. There are (in most cases) minor differences in the elemental composition of ASF when comparing that of a (a) 'normal' ASF with airway surface fluid for patients with 7 bronchial conditions - (b) ASF collected after pretreatment with an anticholinergic therapy, (c) ASF collected after pretreatment with benzodiazepine, (d) ASF while in a hypersecretory state, (e) ASF during sustained airway irritation, (f) ASF during acute airway infection, (g) ASF of cystic fibrosis patients and (h) ASF of severe asthma patients. The compositions used for ASF are detailed in Table 2-8.

Model input files were generated using the PRODEFA2 code (11) for each of the body fluids under investigation. The thermodynamic data in the THERMO.DBS model database (11) that accompanies the MINTEQA2v4 model was compared for compatibility and updated with the critically reviewed chemical thermodynamics NIST database (9). Thermodynamic data on solid phases was also added since in regard to 
beryllium, the THERMO.DBS database contained only $\mathrm{Be}(\mathrm{OH})_{2}$ data. Additional solid thermodynamic data was obtained from Chukhlantsev (21) in the case of the most likely and stable beryllium phosphate, $\mathrm{Be}_{3}\left(\mathrm{PO}_{4}\right)_{2}$, and from Naumov (22) in the case of beryllium metal, $\alpha$-oxide, carbonate, sulfates, chloride and fluoride solids. Chemical thermodynamic data on beryllium phosphates is very sparse and is often overlooked by researchers, but complete chemical speciation in most biological or environmental systems cannot be performed without such data. Even Wood (23) in his review of beryllium environmental chemical thermodynamics omitted phosphate data because of unavailability. Two concentrations of beryllium were used to simulate the low beryllium particle solubility in the biological environment $(1 \mu \mathrm{M}, 9 \mu \mathrm{g} / \mathrm{l})$ and acute poisoning $(1 \mathrm{mM}$, $9 \mathrm{mg} / \mathrm{l}$ ), and the reaction temperature was set to $37^{\circ} \mathrm{C}$. Eisenbud (5) assumed that a typical beryllium lung burden in a CBD patient should be in the order of $10 \mu \mathrm{g}$, while that in the lymph nodes could be in the order of $100 \mu \mathrm{g}$, and that the amounts of beryllium should be lower in the liver and higher in bone than that in the lungs. In cases where fluids are normally in contact with air, the system was equilibrated with atmospheric $\mathrm{CO}_{2}(0.03 \%)$ to maintain carbonate concentrations especially in the cases where carbon was not detailed in the elemental composition. For a simulated fluid model, any element with a concentration less than $5 \%$ of the $1 \mu \mathrm{M}$ total beryllium concentration was removed from the input dataset.

\begin{tabular}{|l|l|l|l|}
\hline & Intracellular & Interstitial & Plasma \\
\hline Element & $\mathrm{mM}$ & $\mathrm{mM}$ & $\mathrm{mM}$ \\
\hline $\mathrm{Ca}$ & 0 & 1.2 & 1.3 \\
\hline $\mathrm{Cl}$ & 4 & 108 & 108 \\
\hline $\mathrm{CO}_{3}$ & 10 & 28.3 & 24 \\
\hline $\mathrm{K}$ & 140 & 4.0 & 4.2 \\
\hline $\mathrm{Mg}$ & 20 & 0.7 & 0.8 \\
\hline $\mathrm{Na}$ & 14 & 139 & 142 \\
\hline $\mathrm{PO}_{4}$ & 11 & 2 & 2 \\
\hline $\mathrm{SO}_{4}$ & 1 & 0.5 & 0.5 \\
\hline $\mathrm{pH}^{[14]}$ & $6.0-7.4$ & 7.4 & 7.4 \\
\hline
\end{tabular}

Table 2-1. Elemental Composition and pH of Human Intracellular, Interstitial and Plasma Fluid (13). 


\begin{tabular}{|l|l|}
\hline Element & $\mathbf{m M}$ \\
\hline $\mathrm{Br}$ & 0.026 \\
\hline $\mathrm{Ca}$ & 1.544 \\
\hline $\mathrm{Cl}$ & 9.432 \\
\hline $\mathrm{Cu}$ & 0.003 \\
\hline $\mathrm{F}$ & 0.009 \\
\hline $\mathrm{I}$ & 0.001 \\
\hline $\mathrm{Mg}$ & 0.296 \\
\hline $\mathrm{Mn}$ & 0.000 \\
\hline $\mathrm{Na}$ & 4.030 \\
\hline $\mathrm{Si}$ & 0.125 \\
\hline $\mathrm{Sr}$ & 0.000 \\
\hline $\mathrm{Zn}$ & 0.001 \\
\hline $\mathrm{pH}{ }^{[15]}$ & $6.0-7.0$ \\
\hline
\end{tabular}

Table 2-2. Elemental Composition and pH of Human Saliva (12) Adjusted by Weighted Mean.

\begin{tabular}{|l|l|l|l|}
\hline Element & $\boldsymbol{\mu}$ Element & $\boldsymbol{\mu}$ \\
\hline $\mathrm{Al}$ & 27.33 & $\mathrm{Li}$ & 102.73 \\
\hline $\mathrm{As}$ & 1.72 & $\mathrm{Mg}$ & 4681.11 \\
\hline $\mathrm{B}$ & 79.44 & $\mathrm{Mn}$ & 10.99 \\
\hline $\mathrm{Ba}$ & 0.52 & $\mathrm{Mo}$ & 0.66 \\
\hline $\mathrm{Be}$ & 14.44 & $\mathrm{Na}$ & 174075.16 \\
\hline $\mathrm{Br}$ & 49.11 & $\mathrm{Nb}$ & 3.88 \\
\hline $\mathrm{Ca}$ & 5285.46 & $\mathrm{Ni}$ & 1.85 \\
\hline $\mathrm{Ce}$ & 0.23 & $\mathrm{P}$ & 18820.02 \\
\hline $\mathrm{Cl}$ & 146666.67 & $\mathrm{~Pb}$ & 0.23 \\
\hline $\mathrm{Co}$ & 0.38 & $\mathrm{Rb}$ & 26.57 \\
\hline $\mathrm{Cr}$ & 0.50 & $\mathrm{~S}$ & 33125.00 \\
\hline $\mathrm{Cs}$ & 0.12 & $\mathrm{Sn}$ & 0.22 \\
\hline $\mathrm{Cu}$ & 0.77 & $\mathrm{Sr}$ & 2.56 \\
\hline $\mathrm{F}$ & 84.21 & $\mathrm{Te}$ & 4.15 \\
\hline $\mathrm{Fe}$ & 5.67 & $\mathrm{Ti}$ & 8.66 \\
\hline $\mathrm{Ga}$ & 0.60 & $\mathrm{~V}$ & 0.44 \\
\hline $\mathrm{Ge}$ & 19.28 & $\mathrm{~W}$ & 0.16 \\
\hline $\mathrm{I}$ & 2.02 & $\mathrm{Zn}$ & 6.91 \\
\hline $\mathrm{K}$ & 64850.81 & $\mathrm{pH}$ & $4.2-8.0$ \\
\hline
\end{tabular}

Table 2-3. Elemental Composition and pH of Human Urine (12) Adjusted by Weighted Mean. 


\begin{tabular}{|l|l|}
\hline Element & $\boldsymbol{\mu \mathbf { M }}$ \\
\hline $\mathrm{Ca}$ & 4.77 \\
\hline $\mathrm{Cl}$ & 43.59 \\
\hline $\mathrm{F}$ & 0.06 \\
\hline $\mathrm{K}$ & 6.74 \\
\hline $\mathrm{Mg}$ & 0.05 \\
\hline $\mathrm{Na}$ & 105.76 \\
\hline $\mathrm{P}$ & 0.02 \\
\hline $\mathrm{pH}^{[15]}$ & $4.2-7.5$ \\
\hline
\end{tabular}

Table 2-4. Elemental Composition and pH of Human Sweat (12) Adjusted by Weighted Mean.

\begin{tabular}{|l|l|}
\hline Element & $\mathbf{m M}$ \\
\hline $\mathrm{Cl}$ & 84.000 \\
\hline $\mathrm{Cu}$ & 0.004 \\
\hline $\mathrm{F}$ & 0.029 \\
\hline $\mathrm{K}$ & 10.524 \\
\hline $\mathrm{Na}$ & 54.543 \\
\hline $\mathrm{P}$ & 1.419 \\
\hline $\mathrm{pH}^{[15]}$ & $1.0-3.5$ \\
\hline
\end{tabular}

Table 2-5. Elemental Composition and pH of Human Gastric Juice (12) Adjusted by Weighted Mean.

\begin{tabular}{|l|l|}
\hline Element & mM \\
\hline $\mathrm{Al}$ & 14.852 \\
\hline $\mathrm{Cl}$ & 89.324 \\
\hline $\mathrm{Cu}$ & 1.652 \\
\hline $\mathrm{Fe}$ & 8.208 \\
\hline $\mathrm{K}$ & 4.744 \\
\hline $\mathrm{Mn}$ & 0.057 \\
\hline $\mathrm{Na}$ & 121.478 \\
\hline $\mathrm{Si}$ & 18.932 \\
\hline $\mathrm{pH}^{[14]}$ & $8.0-8.3$ \\
\hline
\end{tabular}

Table 2-6. Elemental Composition and pH of Human Pancreatic Fluid (12) Adjusted by Weighted Mean. 


\begin{tabular}{|l|l|}
\hline Element & $\boldsymbol{\mu M}$ \\
\hline $\mathrm{Al}$ & 15.11 \\
\hline $\mathrm{Ca}$ & 451.54 \\
\hline $\mathrm{Cd}$ & 0.02 \\
\hline $\mathrm{Cl}$ & 65.69 \\
\hline $\mathrm{Cu}$ & 1.74 \\
\hline $\mathrm{Fe}$ & 12.38 \\
\hline $\mathrm{K}$ & 1391.25 \\
\hline $\mathrm{Mg}$ & 323.46 \\
\hline $\mathrm{Mn}$ & 0.34 \\
\hline $\mathrm{Na}$ & 8027.89 \\
\hline $\mathrm{P}$ & 112.77 \\
\hline $\mathrm{Pb}$ & 0.10 \\
\hline $\mathrm{Si}$ & 65.20 \\
\hline $\mathrm{Zn}$ & 2.09 \\
\hline $\mathrm{pH}{ }^{[14]}$ & 7.8 \\
\hline
\end{tabular}

Table 2-7. Elemental Composition and pH of Human Bile (12) Adjusted by Weighted Mean.

\begin{tabular}{|l|l|l|l|l|l|l|l|l|}
\hline Element & $($ a) & (b) & (c) & (d) & (e) & (f) & $($ g) & (h) \\
\hline $\mathrm{Ca}$ & 4 & 4 & 5 & 4 & & & & \\
\hline $\mathrm{Cl}$ & 84 & 78 & 104 & 162 & 111 & 143 & 129 & 37 \\
\hline $\mathrm{K}$ & 29 & 32 & 18 & 13 & 22 & 22 & 23 & 21 \\
\hline $\mathrm{Na}$ & 82 & 79 & 91 & 165 & 116 & 147 & 121 & 27 \\
\hline $\mathrm{P}$ & 17 & 17 & 10 & 27 & & & & \\
\hline $\mathrm{S}$ & 21 & 23 & 11 & & & & & \\
\hline
\end{tabular}

Table 2-8. Elemental Composition of Human ASF (17-19) $\mu M$. ASF of patients during the following conditions: (a) Normal, (b) post antichlolinergic pretreatment, (c) postbenzodiazepine pretreatment, $(d)$ hypersecretory, $(e)$ sustained airway irritation, $(f)$ acute airway infection, $(g)$ cystic fibrosis and $(h)$ severe asthma. The $\mathrm{pH}$ for all ASF cases assumed to be 7.0 (19).

The effect of $\mathrm{pH}$ on the beryllium speciation was investigated for each fluid, and speciation studied more rigorously at the actual biological $\mathrm{pH}$ of each fluid. Once each model was programmed in terms of element concentrations and $\mathrm{pH}$, the MINTEQA2 code was run and the beryllium speciation data was transferred to Microsoft Excel for data analysis. For comparison, speciation models of beryllium in water $\left(\mathrm{CO}_{2}\right.$ free $)$ and air/water $\left(\mathrm{CO}_{2}\right)$ systems were also performed. 


\subsection{Results and Discussion}

The results obtained by chemical thermodynamic modeling allow the examination of the aqueous chemistry of beryllium with other elemental constituents of the biological fluids.

The speciation of beryllium in $\mathrm{CO}_{2}$-free water at $37^{\circ} \mathrm{C}$ is shown in Figure $2-1$ for dilute and concentrated beryllium. The results of such speciation diagrams show "how" the soluble beryllium is chemically distributed after reacting with other constituents of the chemical system. At the lower concentrations of beryllium, the early hydrolysis in the $\mathrm{pH}$ 5 region is dominated by the formation of monomeric hydroxides such as $\mathrm{BeOH}^{+}$and $\mathrm{Be}(\mathrm{OH})_{2}$. In solutions of higher beryllium concentration, dimers and trimers (namely $\mathrm{Be}_{2} \mathrm{OH}^{+++}$and $\mathrm{Be}_{3}(\mathrm{OH})_{3}{ }^{+++}$) are formed, but do not strictly dominate the hydrolysis. However, at the $\mathrm{pH}$ region of most biological fluids (approx $\mathrm{pH}$ 7), the speciation of the dilute and concentrated systems are similar. This is in part due to the formation of the beryllium solubility controlling phase, $\mathrm{Be}(\mathrm{OH})_{2}$ solid. As shown in Figure 2-2, beryllium carbonate complexes start to form at neutral $\mathrm{pH}$ in the presence of $\mathrm{CO}_{2}$ but do not proceed to dominate the beryllium speciation until above $\mathrm{pH} 10$.
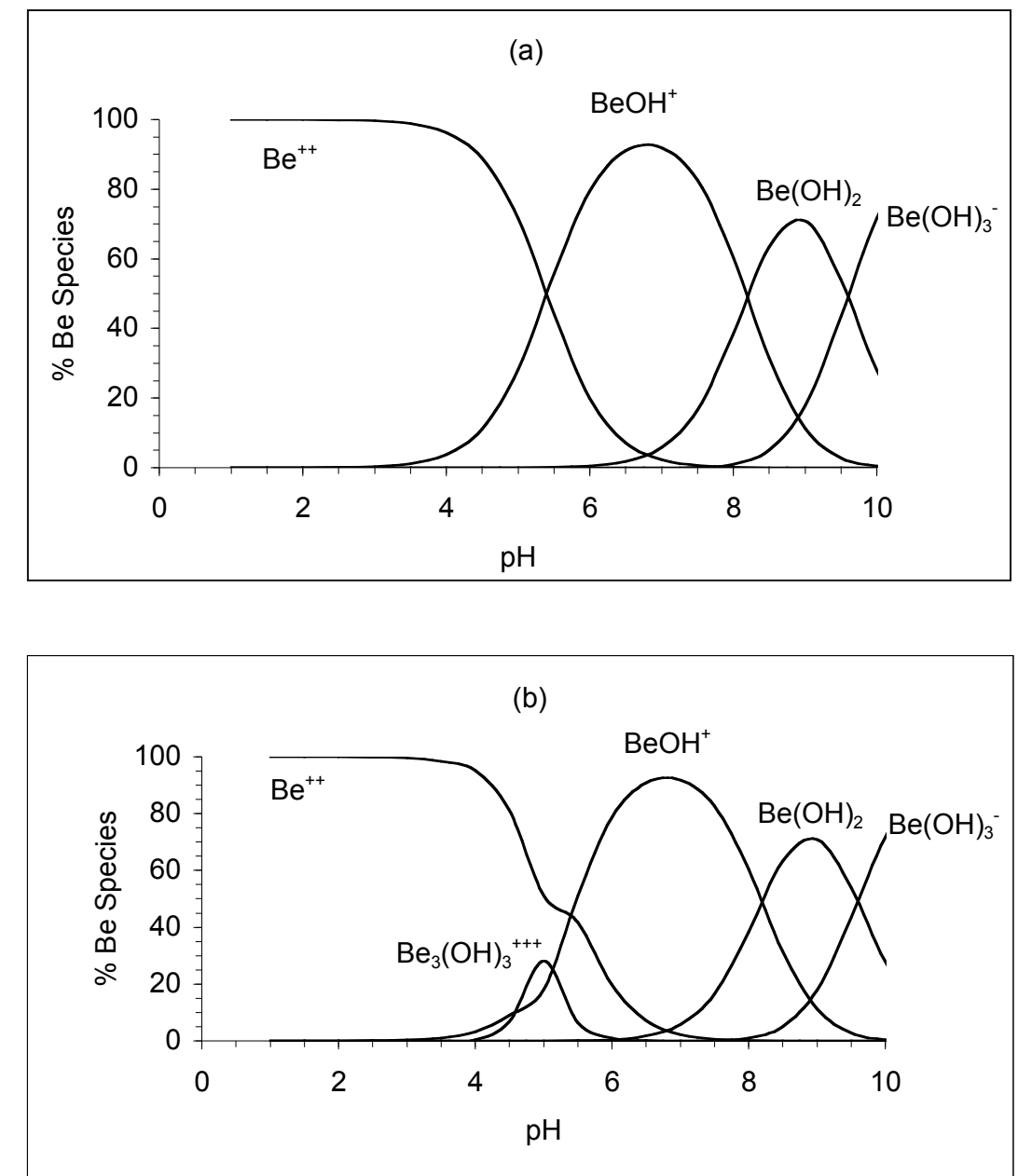

Figure 2-1. Beryllium speciation with varying $\mathrm{pH}$ in the Be-OH system at $[\mathrm{Be}]=($ a) $1 \mu \mathrm{M}$ and (b) $1 \mathrm{mM}$. 


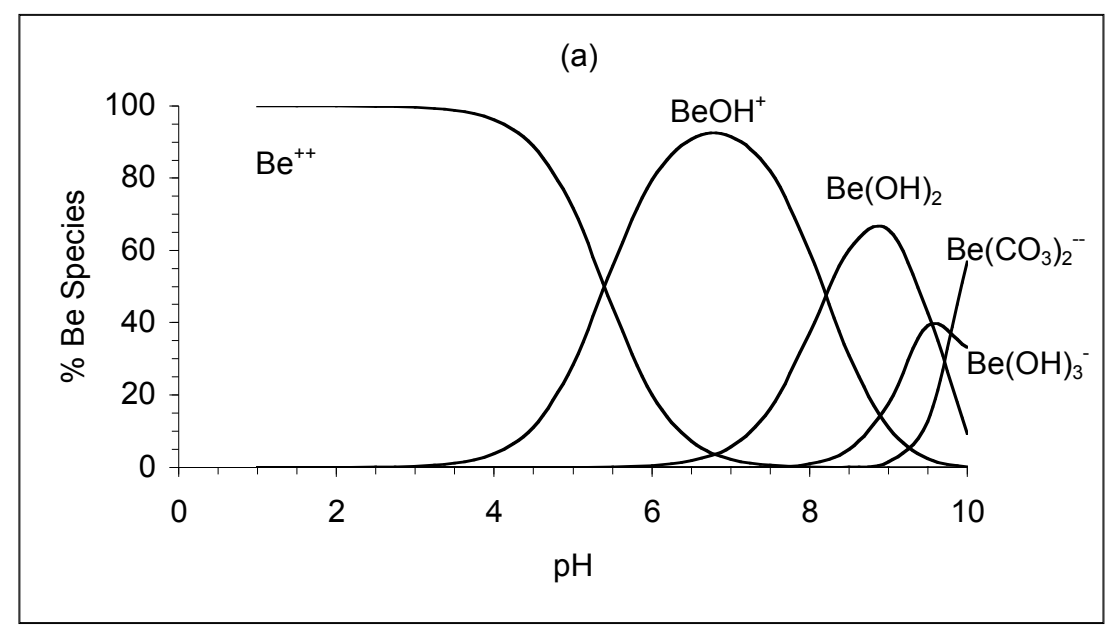

(b)

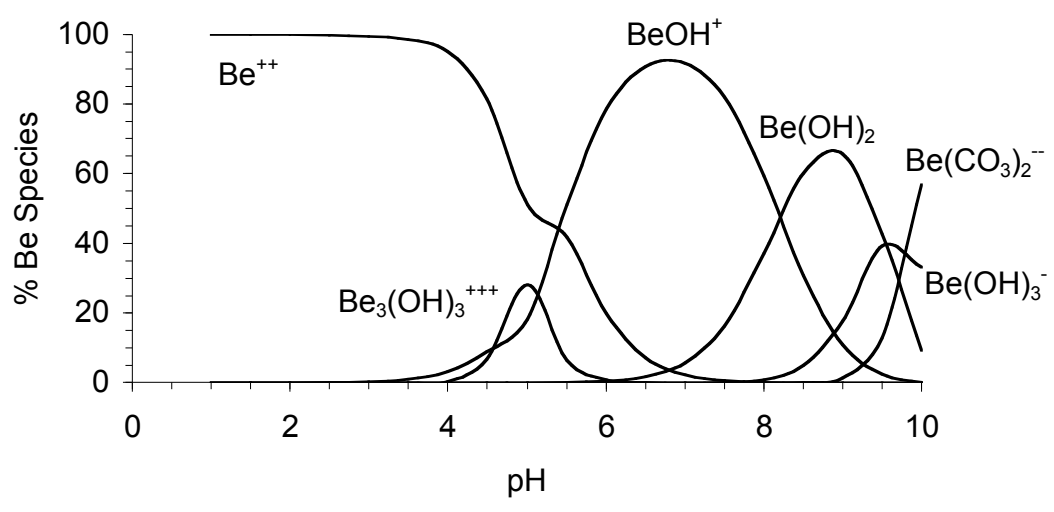

Figure 2-2. Beryllium speciation with varying $\mathrm{pH}$ in the $\mathrm{Be}-\mathrm{OH}-\mathrm{CO}_{3}$ system at $[\mathrm{Be}]=(a)$ $1 \mu M$ and (b) $1 m M$.

In the case of intracellular (ICF) and extracellular (ECF) fluids, three chemical systems were examined: intracellular fluid, interstitial fluid and plasma water. The beryllium speciation diagrams for each of these simulated fluids with beryllium concentrations of $1 \mu \mathrm{M}$ and $1 \mathrm{mM}$ are shown in Figures 2-3 through 2-5. Within the biologically correct $\mathrm{pH}$ range for intracellular fluid $(6.0-7.4(13))$ the major species (Figure 2-3) are shown to be aqueous $\mathrm{Be}\left(\mathrm{H}_{2} \mathrm{PO}_{4}\right)_{2}(39.7 \%), \mathrm{BeOH}^{+}(27.0 \%), \mathrm{Be}^{++}(15.2 \%), \mathrm{BeH}_{2} \mathrm{PO}_{4}^{+}(9.6 \%)$ and aqueous $\mathrm{BeCO}_{3}(5.7 \%)$ at $\mathrm{pH} 6.0$ and $\mathrm{BeOH}^{+}(60.2 \%)$, aqueous $\mathrm{BeCO}_{3}(28.8 \%)$, aqueous $\mathrm{Be}(\mathrm{OH})_{2}(7.6 \%), \mathrm{Be}^{++}(1.6 \%)$, at $\mathrm{pH} 7.4$ in dilute beryllium solutions. In more concentrated solutions of $1 \mathrm{mM}$ total beryllium the speciation is almost identical to that of the dilute solution. The high concentration of phosphate in ICF allows significant phosphate complexation of beryllium and also accounts for the difference in beryllium

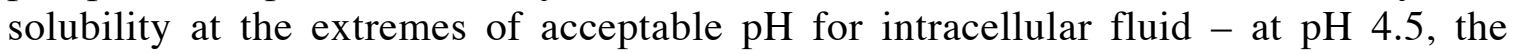
beryllium solubility is limited to $7.92 \mu \mathrm{M}$ by solid $\mathrm{Be}_{3}\left(\mathrm{PO}_{4}\right)_{2}$, while at $\mathrm{pH} 7.0$ the beryllium solubility is $1.23 \mu \mathrm{M}$ as defined by solid $\mathrm{Be}(\mathrm{OH})_{2}$ formation. The presence of phosphate complexation also limits the formation of dimeric and trimeric beryllium hydroxide species. Of course, even lower $\mathrm{pH}$ ranges may be encountered (perhaps as low 
as $\mathrm{pH}$ 4) in the phagocytic lysosomal environments of macrophages within intracellular fluid (where beryllium particles trapped in the lungs are dissolved, the breakdown of which releases beryllium-antigen into the lungs and consequently further inflammation and granulomatous formation (6)). In this case, the speciation of beryllium would show an increase in the amount of aqueous $\mathrm{Be}\left(\mathrm{H}_{2} \mathrm{PO}_{4}\right)_{2}$ and a decrease in $\mathrm{BeOH}^{+}$, as shown in Figure 2-3.
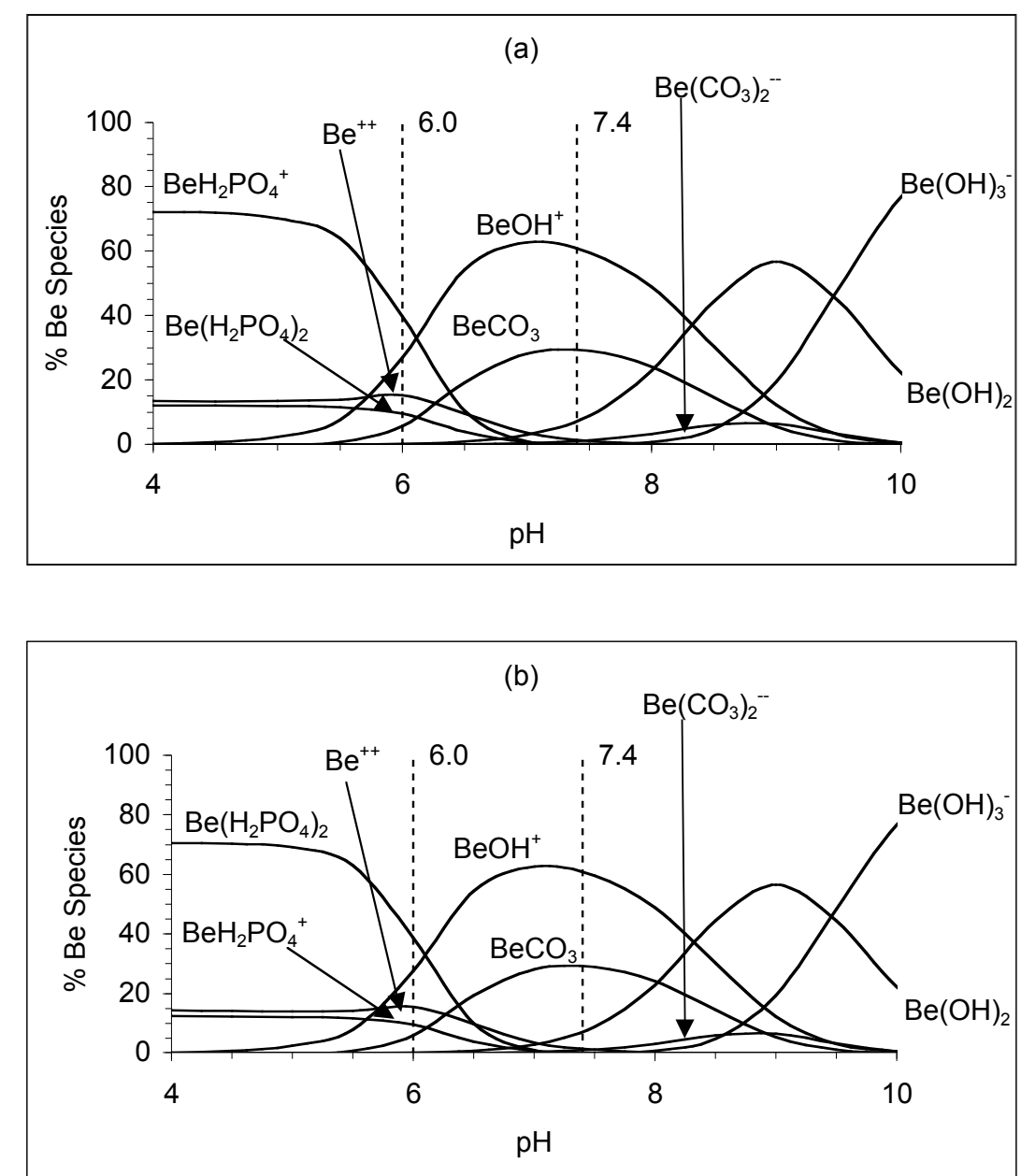

Figure 2-3. Beryllium speciation in simulated intracellular fluid, $[\mathrm{Be}]=(a) 1 \mu \mathrm{M}$ and $(\mathrm{b})$ $\operatorname{lm} M$.

In simulated interstitial fluid at $\mathrm{pH} 7.4$ (Figure 2-4), the major beryllium species in both concentrated and dilute solutions are aqueous $\mathrm{BeCO}_{3}(50.9 \%), \mathrm{BeOH}^{+}(38.2 \%)$, $\mathrm{Be}\left(\mathrm{CO}_{3}\right)_{2}{ }^{2-}(5.1 \%)$ and aqueous $\mathrm{Be}(\mathrm{OH})_{2}(4.8 \%)$. The phosphate concentration in interstitial fluid is lower than in that of intracellular fluid and so phosphate complexation is not sufficient to compete with the hydrolysis of beryllium at this neutral $\mathrm{pH}$. The solubility of beryllium is limited (above $\mathrm{pH}$ 6) to $1.93 \mu \mathrm{M}$ by solid $\mathrm{Be}(\mathrm{OH})_{2}$ formation. At $\mathrm{pH}$ regions between 5 and 6 in simulated interstitial fluid, beryllium phosphate precipitation is observed. A similar case is true for that of simulated plasma fluid (Figure $2-5$ ) in which the speciation of beryllium is shown to be aqueous $\mathrm{BeCO}_{3}(49.4 \%)$, 
$\mathrm{BeOH}^{+}(39.9 \%)$, aqueous $\mathrm{Be}(\mathrm{OH})_{2}(5.0 \%)$ and $\mathrm{Be}\left(\mathrm{CO}_{3}\right)_{2}{ }^{2-}(4.6 \%)$, and where the total beryllium solubility is $1.86 \mu \mathrm{M}$. This suggests that the concentration of beryllium in elemental cellular fluids would be higher inside the cell than outside the cell. The difference between the speciation of these three cellular fluids is largely due to the difference in phosphate and carbonate concentrations.
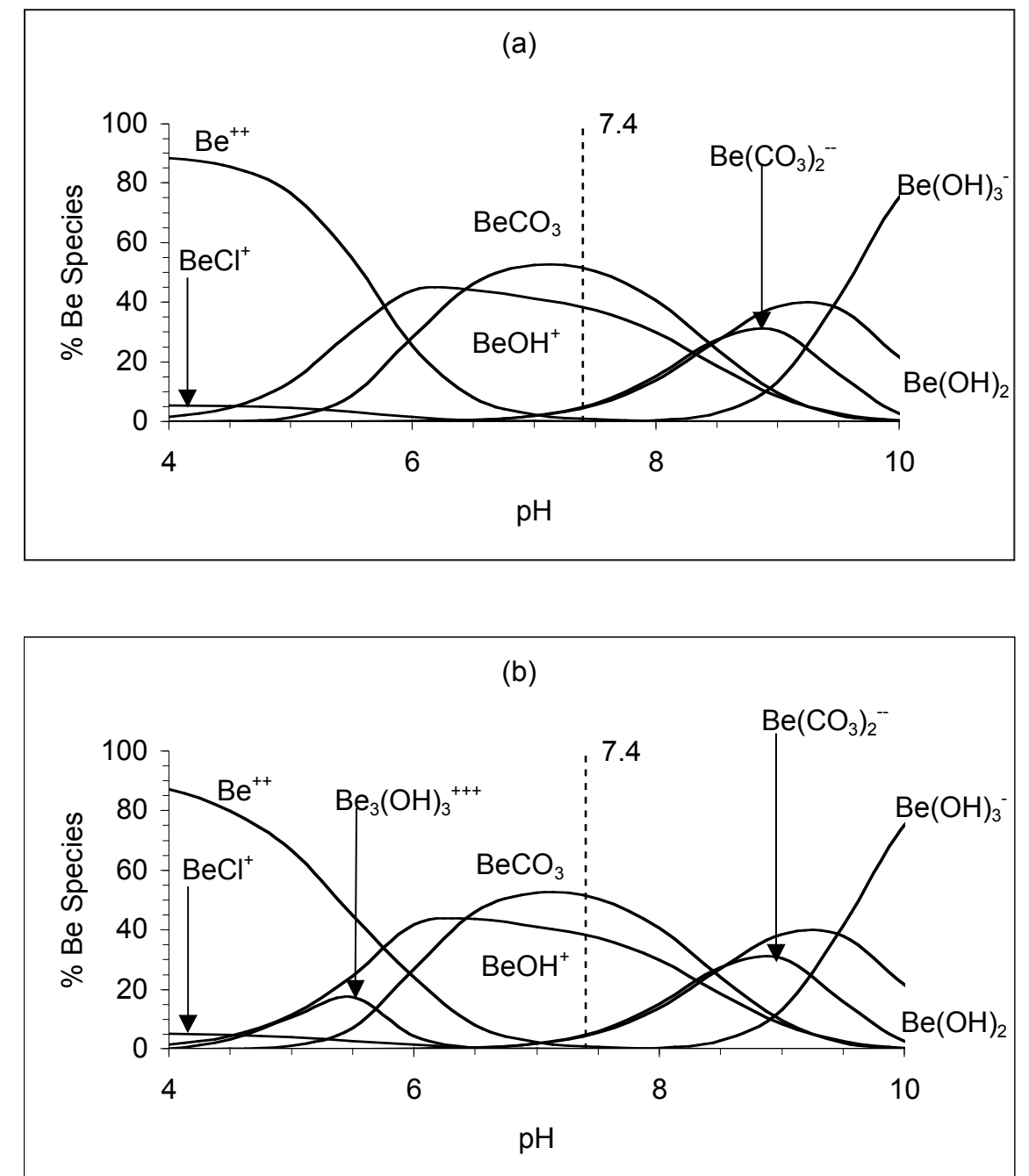

Figure 2-4. Beryllium speciation in simulated interstitial fluid, $[\mathrm{Be}]=(a) 1 \mu \mathrm{M}$ and $(b)$ $1 \mathrm{mM}$. 


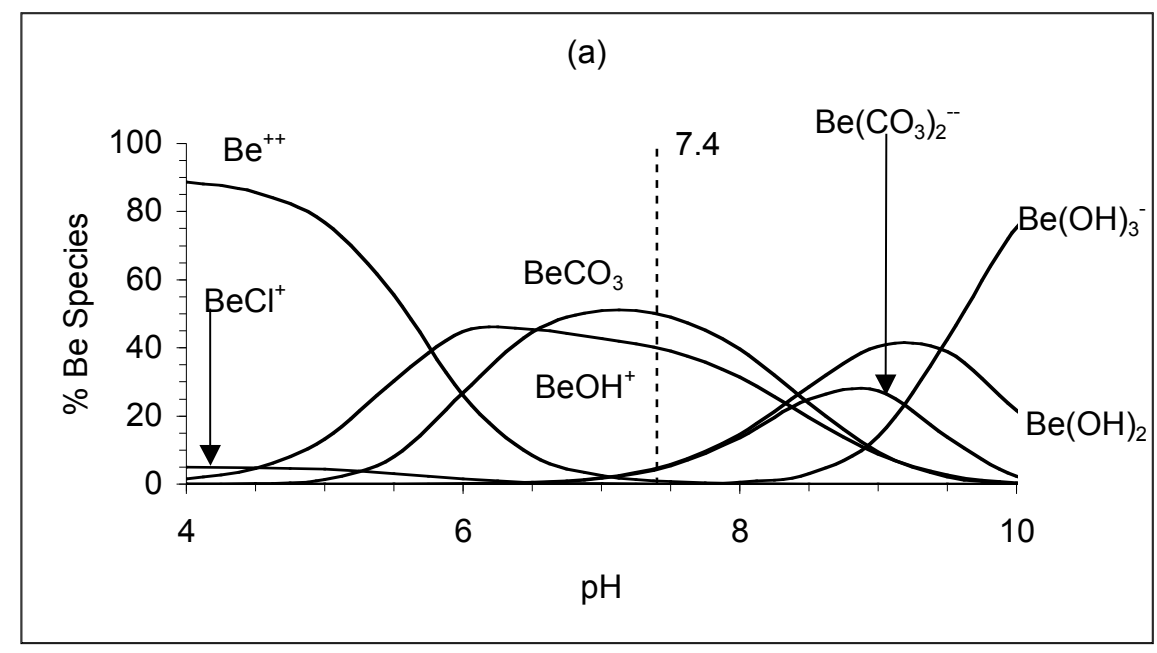

(b)

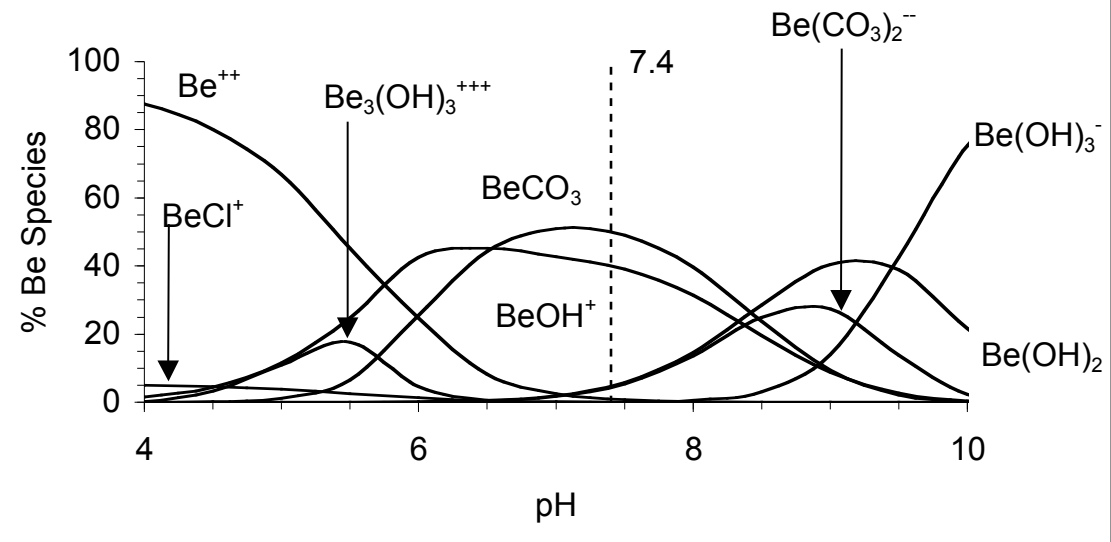

Figure 2-5. Beryllium speciation in simulated plasma fluid, $[\mathrm{Be}]=($ a) $1 \mu \mathrm{M}$ and (b) $1 \mathrm{mM}$

The modeled speciation of beryllium in simulated saliva is shown graphically in Figure 2-6. In dilute concentrations, beryllium prefers to exist as the mixed hydroxyfluoride species $\mathrm{Be}(\mathrm{OH})_{2} \mathrm{~F}^{-}$at $\mathrm{pH}$ values even as low as $\mathrm{pH} 4$, where one would perhaps not expect to see such strong speciation dependence on such a hydroxyfluoride species, especially since the chloride concentration in saliva is one thousand times that of fluoride. This observation is largely due to the high stabilization of the beryllium fluoride complex because the beryllium ionic radius is small, as is that of fluoride (allowing a closer bond between the ions). The difference in electronegativity in $\mathrm{Be}-\mathrm{F}$ is the highest of any beryllium compound and the oxygen atoms have lone pairs of electrons to form coordinate bonds and further stabilize the $\mathrm{Be}(\mathrm{OH})_{2} \mathrm{~F}^{-}$species. In the more concentrated beryllium systems the major beryllium speciation at the lower $\mathrm{pH}$ value for saliva $(\mathrm{pH}$ 6.0) is given as $\mathrm{BeOH}^{+}(49.3 \%), \mathrm{Be}(\mathrm{OH})_{2} \mathrm{~F}^{-}(31.8 \%)$ and $\mathrm{Be}^{++}(17 \%)$ and at the higher $\mathrm{pH}$ value $(\mathrm{pH} 7.0), \mathrm{Be}(\mathrm{OH})_{2} \mathrm{~F}^{-}(85.5 \%), \mathrm{BeOH}^{+}(13.2 \%)$. This differs from that of the dilute system because there is slightly more beryllium available in solution $(28.3 \mu \mathrm{M}$ at $\mathrm{pH} 6.0$ and $10.5 \mu \mathrm{M}$ at $\mathrm{pH} 7.0$ ). This difference in solubility also explains why at the higher $\mathrm{pH}$ 
(where more $\mathrm{OH}^{-}$is available for beryllium hydroxide solid formation), the concentration of beryllium is reduced and fluoride (at $9 \mu \mathrm{M}$ abundance) has a greater effect on the aqueous speciation. While the occurrence of beryllium in saliva might seem at first minor, Wataha et al (24) have recently found that brushing $\mathrm{Ni}-\mathrm{Cr}$-Be prosthodontics in saline solutions at $\mathrm{pH} 4$ with toothpaste gave significant increases in beryllium release by more than $60 \%$.
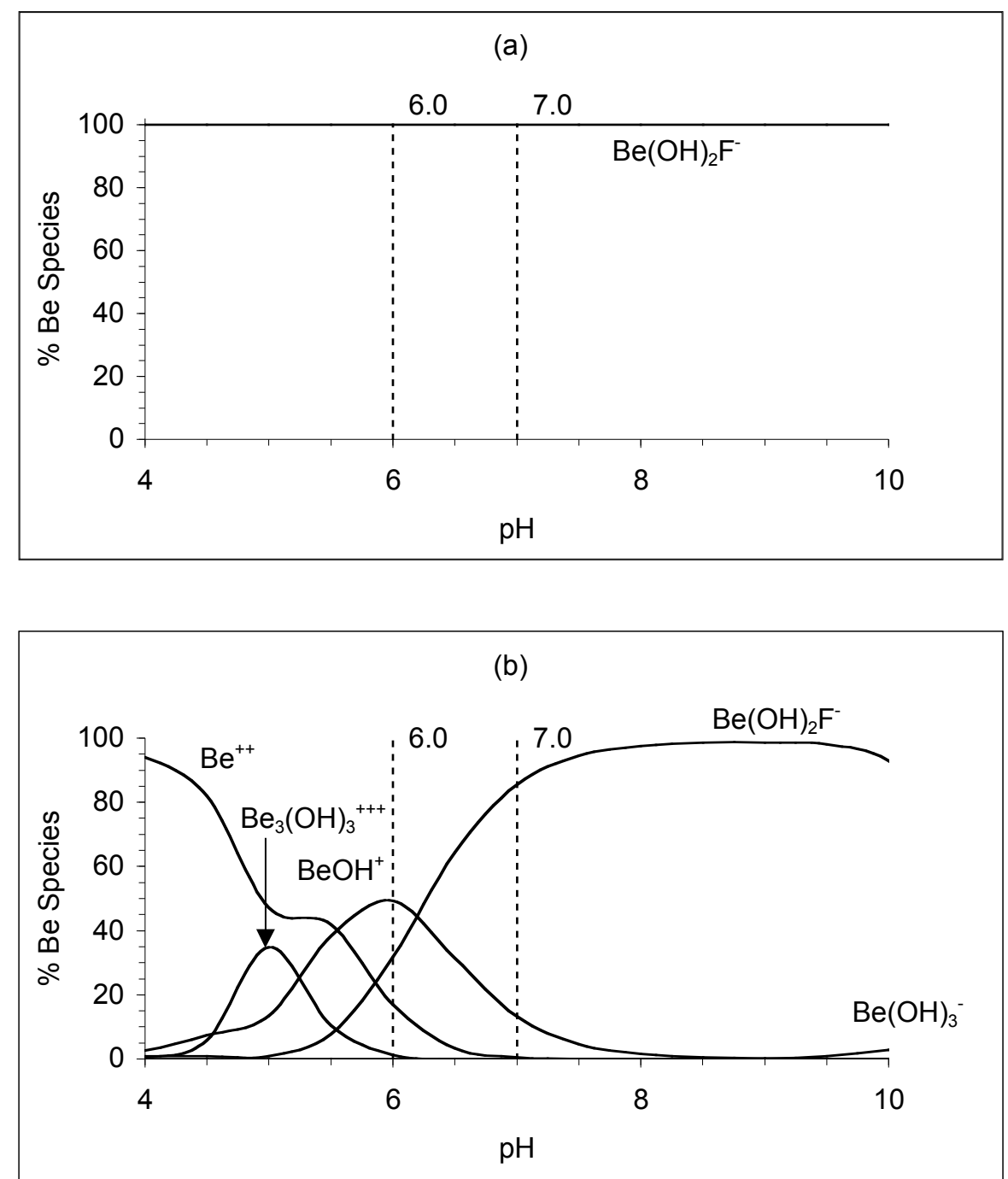

Figure 2-6. Beryllium speciation in simulated saliva, $[\mathrm{Be}]=($ a) $1 \mu \mathrm{M}$ and (b) $1 \mathrm{mM}$.

There are also similarities between the predicted speciation of beryllium in saliva and urine. Model speciation of beryllium in simulated urine (Figure 2-7), show beryllium in dilute concentrations is bound completely as $\mathrm{Be}(\mathrm{OH})_{2} \mathrm{~F}^{-}$, but at higher beryllium concentrations the speciation and solubility differs greatly. At $\mathrm{pH} 4.2$ the beryllium speciation is given as aqueous $\mathrm{Be}\left(\mathrm{H}_{2} \mathrm{PO}_{4}\right)_{2}(37.6 \%), \mathrm{Be}^{++}(26.7 \%), \mathrm{BeH}_{2} \mathrm{PO}_{4}^{+}(12.0 \%)$, aqueous $\mathrm{BeSO}_{4}(10.8 \%)$ and $\mathrm{Be}(\mathrm{OH})_{2} \mathrm{~F}^{-}(10.3 \%)$. At the higher $\mathrm{pH}$ level quoted for urine ( $\mathrm{pH} 8.0$ ), the major species in solution is $\mathrm{Be}(\mathrm{OH})_{2} \mathrm{~F}^{-}$at $99.7 \%$. The solubility of beryllium within these $\mathrm{pH}$ ranges varies also since at the lower $\mathrm{pH}$ limit the formation of beryllium phosphate yields a solubility of $0.9 \mathrm{mM}$, while at the upper $\mathrm{pH}$ limit the solubility is 
defined by solid $\mathrm{Be}(\mathrm{OH})_{2}$ and is equal to $84.5 \mu \mathrm{M}$ due to the high phosphate concentrations available in urine. Additionally, while it should be noted that human urine is highly variable and dependent on diet and environment, the high stability of the beryllium hydroxyfluoride species suggests the speciation would be largely unaffected by the varying composition of urine. A recent study of urinary beryllium levels by Horng et al (25) reported beryllium excretion in steel production workers to be $1.58 \mu \mathrm{g} / \mathrm{L}(0.2 \mu \mathrm{M})$, a $90 \%$ increase when compared to non-production worker controls.
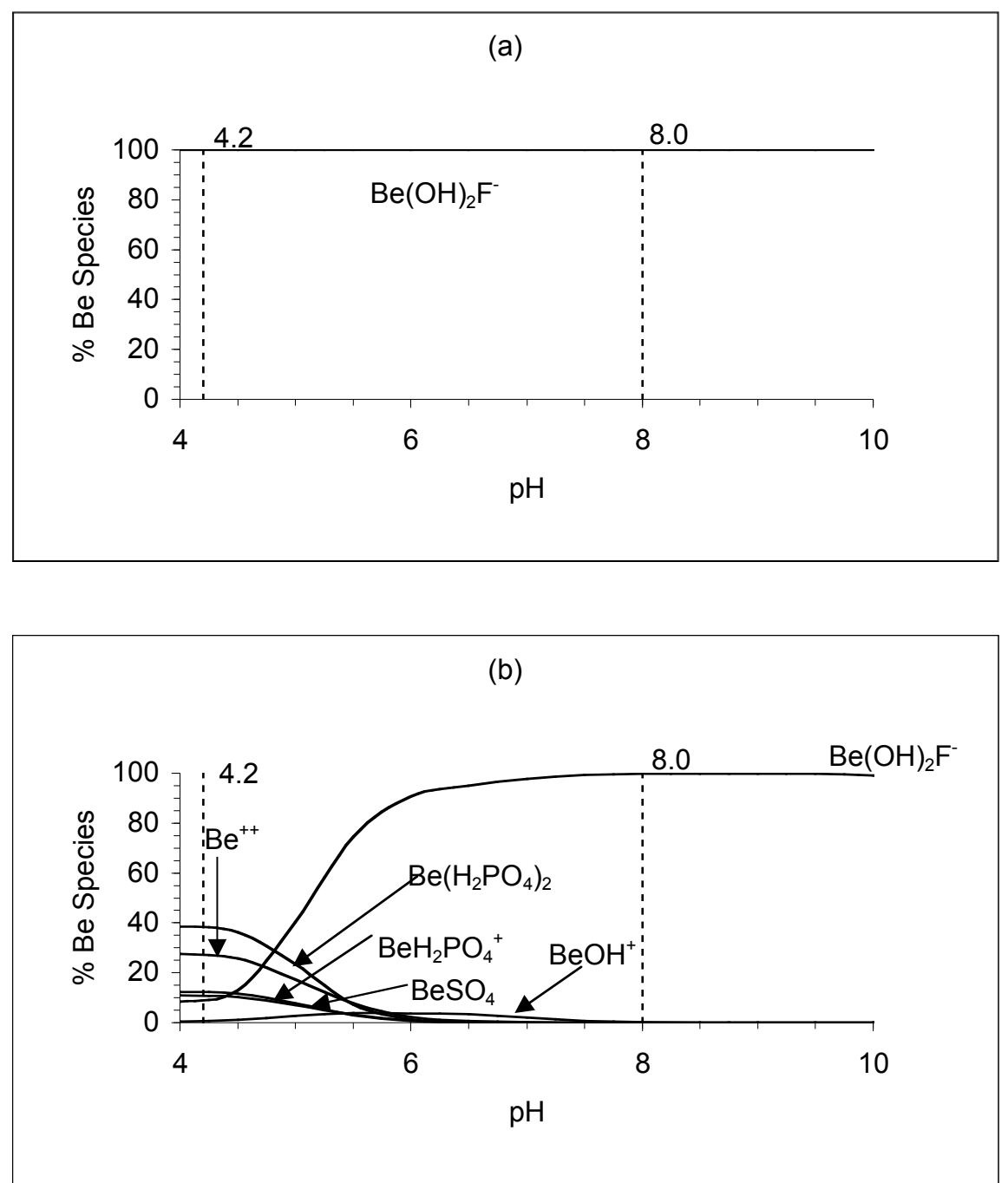

Figure 2-7. Beryllium speciation in simulated urine, $[\mathrm{Be}]=($ a) $1 \mu \mathrm{M}$ and (b) $1 \mathrm{mM}$.

In simulated sweat, beryllium at dilute concentrations (Figure 2-8) is present in solution as $\mathrm{BeOH}^{+}(6.2 \%), \mathrm{Be}^{++}(88.0 \%)$ and $\mathrm{Be}(\mathrm{OH})_{2} \mathrm{~F}^{-}(5.8 \%)$ at $\mathrm{pH} 4.2$ and $\mathrm{BeOH}^{+}(73.4 \%)$, aqueous $\mathrm{Be}(\mathrm{OH})_{2}(14.5 \%)$ and $\mathrm{Be}(\mathrm{OH})_{2} \mathrm{~F}^{-}(10.6 \%)$ at $\mathrm{pH}$ 7.5. In more concentrated beryllium systems the speciation changes only slightly to reflect once again the lack of availability to maintain fluoride complexation and also the formation of the trimer hydroxide: $\mathrm{BeOH}^{+}(5.5 \%), \mathrm{Be}^{++}(89.6 \%), \mathrm{Be}_{3}(\mathrm{OH})_{3}{ }^{+++}(2.9 \%)$ at $\mathrm{pH} 4.2$ and $\mathrm{BeOH}^{+}$ (73.3\%), $\mathrm{Be}(\mathrm{OH})_{2}(14.5 \%)$ and $\mathrm{Be}(\mathrm{OH})_{2} \mathrm{~F}^{-}(10.6 \%)$ at $\mathrm{pH} 7.5$ respectively. The solubility of the limiting phase, solid $\mathrm{Be}(\mathrm{OH})_{2}$, is predicted to be $1 \mathrm{mM}$ at $\mathrm{pH} 4.2$ and $0.5 \mu \mathrm{M}$ at $\mathrm{pH} 7$ 
.5 respectively. The concentration of phosphate in simulated sweat was too low to affect the speciation or solubility of beryllium at any $\mathrm{pH}$ studied. There is currently much discussion as to whether beryllium skin absorption occurs $(26,27)$ and much of the available beryllium may be bound to the components of the epidermal layer by phosphatase (28). However, the identification of these soluble species should direct researchers towards the ability of sweat on the hands of a machinist or worker to partially solubilize small quantities of beryllium oxide.

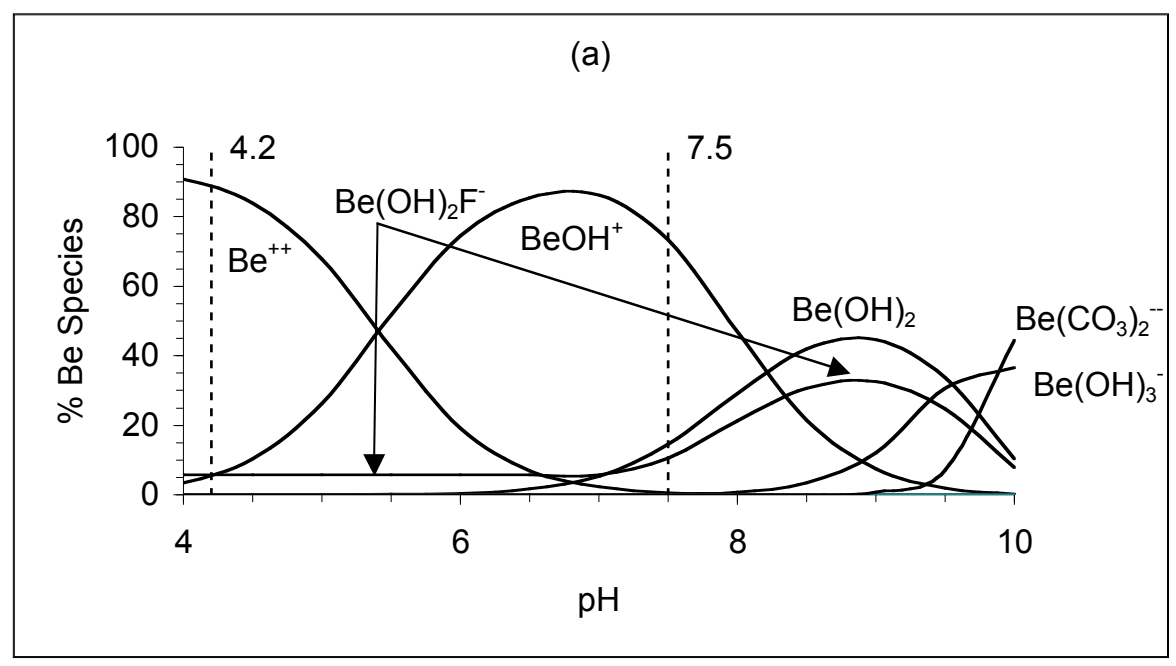

(b)

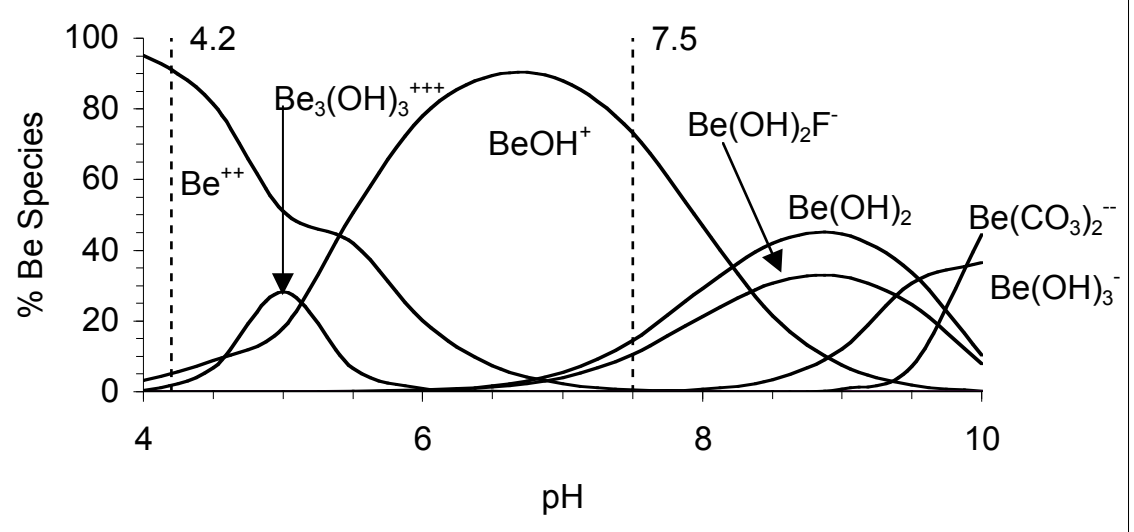

Figure 2-8. Beryllium speciation in simulated sweat, $[\mathrm{Be}]=($ a) $1 \mu \mathrm{M}$ and (b) $1 \mathrm{mM}$.

The mixed hydroxyfluoride beryllium ion is also of importance in the speciation of dilute beryllium in simulated gastric juice (Figure 2-9). Even as low as $\mathrm{pH} 1$ to 3.5, this species dominates the aqueous chemistry, which was originally unexpected at such low hydroxide concentrations $(0.0001 \mathrm{nM}$ to $0.03 \mathrm{nM})$, and demonstrates the high stability of the beryllium fluoride complex. At higher beryllium concentrations, the speciation is somewhat less dependent on the fluoride species. At $\mathrm{pH} 1$, the major beryllium species are $\mathrm{Be}^{++}(92.7 \%), \mathrm{BeCl}^{+}(4.1 \%)$ and $\mathrm{Be}(\mathrm{OH})_{2} \mathrm{~F}^{-}(2.9 \%)$, while at $\mathrm{pH} 3.5$ the major 
speciation are $\mathrm{Be}^{++}(85.4 \%), \mathrm{BeCl}^{+}(4.6 \%), \mathrm{BeH}_{2} \mathrm{PO}_{4}^{+}(4.3 \%)$ and $\mathrm{Be}(\mathrm{OH})_{2} \mathrm{~F}^{-}(2.9 \%)$. Notice here the chloride concentration must be at almost three thousand times that of fluoride in order to allow $\mathrm{BeCl}^{+}$to compete on the same scale as $\mathrm{Be}(\mathrm{OH})_{2} \mathrm{~F}^{-}$even at such a low $\mathrm{pH}$. It should also be noted that neither aqueous and solid $\mathrm{BeCl}_{2}$ form even at such relatively high chloride concentrations as those seen in gastric juice. The relatively low $\mathrm{pH}$ is responsible for the lack of carbonate available in the aqueous system, having been fully protonated and further converted to $\mathrm{CO}_{2}(\mathrm{~g})$ and $\mathrm{H}_{2} \mathrm{O}$.
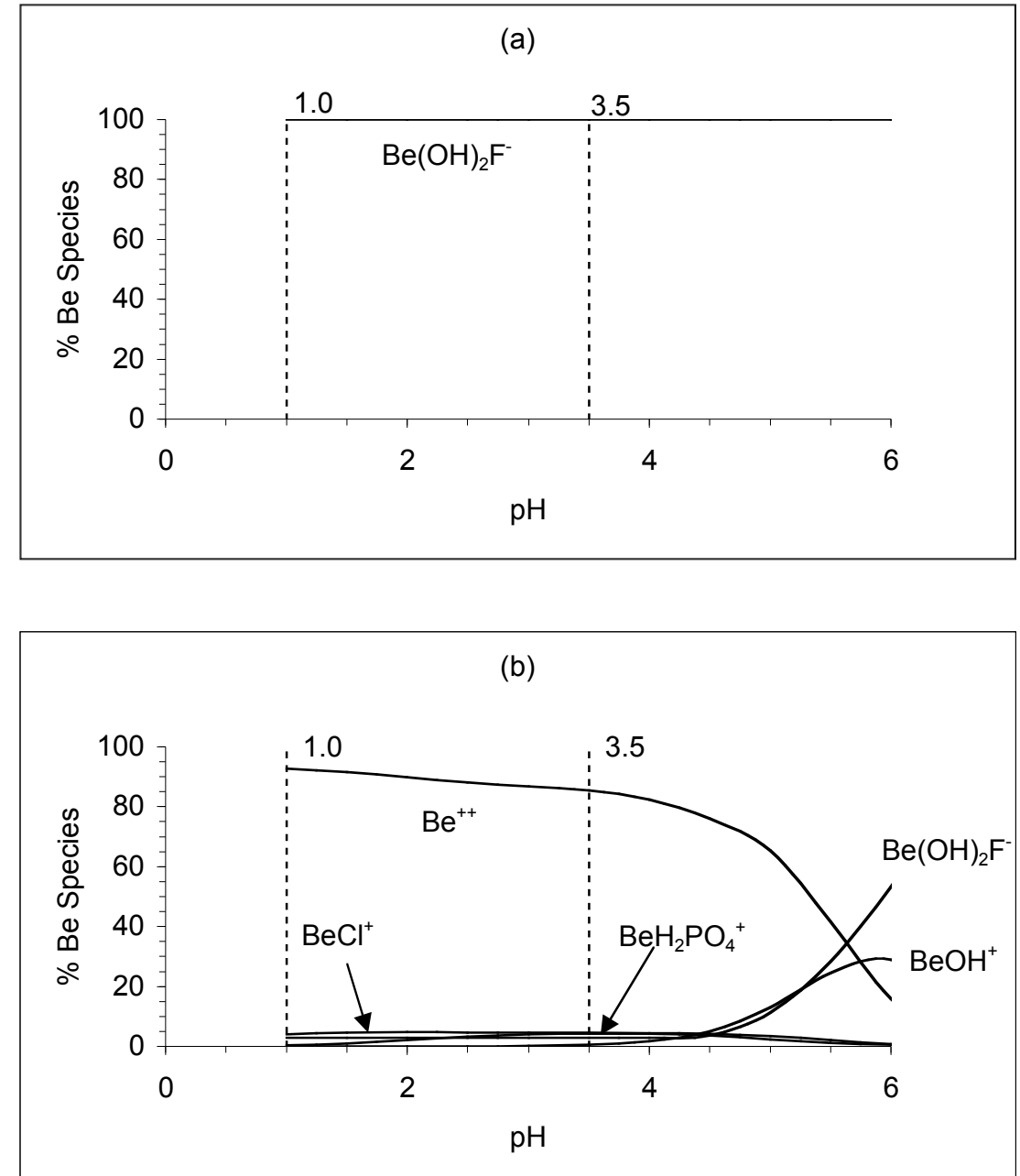

Figure 2-9. Beryllium speciation in simulated gastric juice, $[\mathrm{Be}]=($ a) $1 \mu \mathrm{M}$ and (b) $1 \mathrm{mM}$.

Reeves (26) in summarizing work from a number of researchers noted a lack of beryllium absorption in the GI tract due to the formation of beryllium phosphate solids that govern the GI absorption of beryllium. However, in modeling beryllium in gastric juice, we find that for solid $\mathrm{Be}_{3}\left(\mathrm{PO}_{4}\right)_{2}$ (the most likely and stable beryllium phosphate phase (29)) precipitation should not occur until at or above $\mathrm{pH} 4.5$. This difference may be in part by co-precipitation, variation in $\mathrm{pH}$ or gastric juice composition, or the effect of alkaline phosphatase on the chemistry of beryllium and phosphate. The results do however give supportive chemical thermodynamic evidence that possible beryllium phosphate precipitation may occur in the GI tract, therefore minimizing beryllium absorption into 
the blood, and allowing excretion of solid beryllium in feces. Above $\mathrm{pH} 7.0$, the solubility limiting phase for beryllium in simulated gastric juice becomes the solid hydroxide, $\mathrm{Be}(\mathrm{OH})_{2}$ with a minimum beryllium solubility of $29.1 \mu \mathrm{M}$ at $\mathrm{pH} 9.0$.
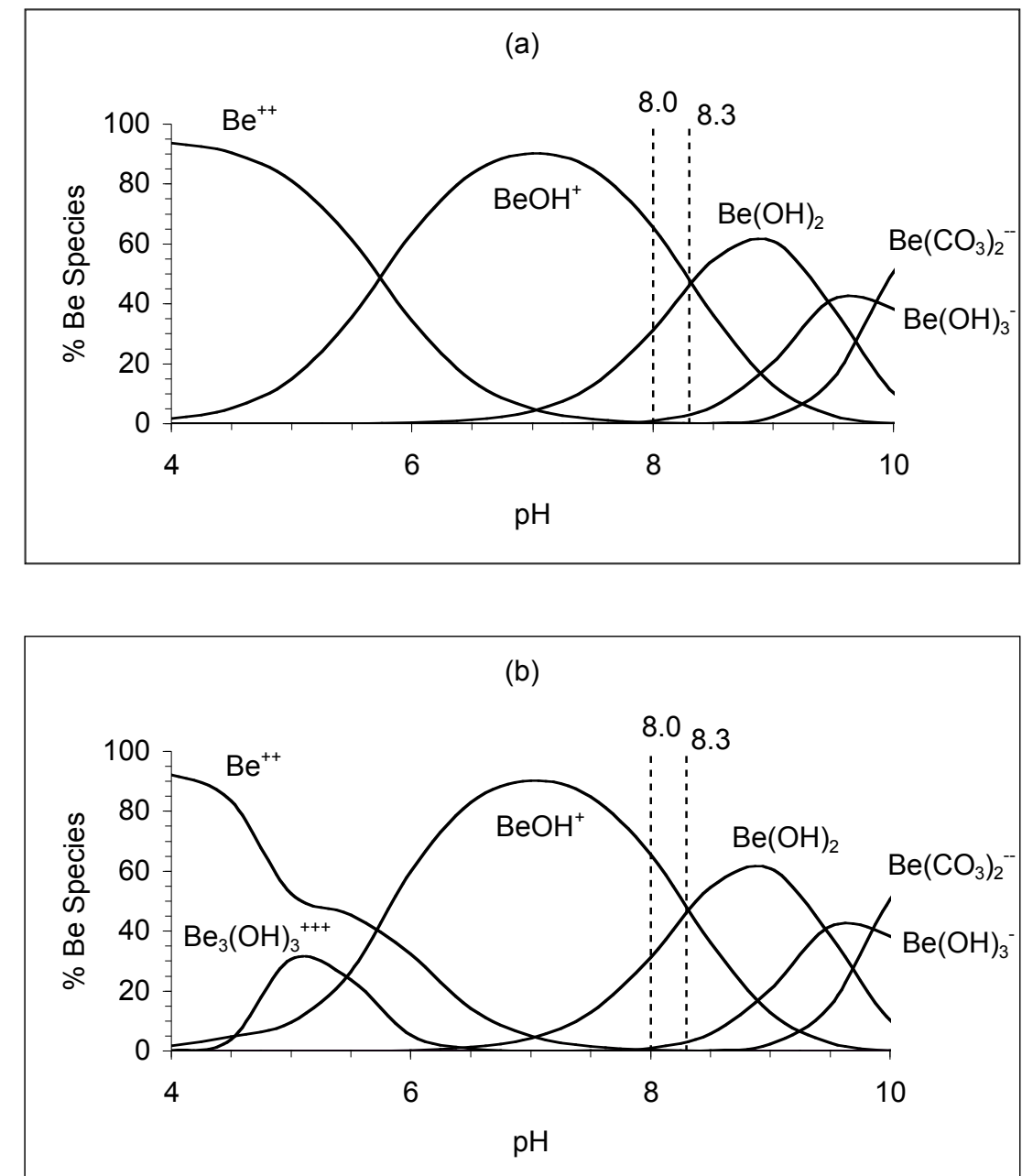

Figure 2-10. Beryllium speciation in simulated pancreatic fluid, $[\mathrm{Be}]=(\mathrm{a}) 1 \mu \mathrm{M}$ and $(\mathrm{b})$ $1 \mathrm{mM}$.

Except for the presence of dimeric and trimeric beryllium hydroxide species at lower $\mathrm{pH}$ in simulated pancreatic fluid shown in Figure 2-10, the speciation diagrams for both dilute and concentrated beryllium can be assumed to be almost identical and at $\mathrm{pH} 8.0$ are detailed as $\mathrm{BeOH}^{+}(65.6 \%)$ and aqueous $\mathrm{Be}(\mathrm{OH})_{2}(31.3 \%)$. At the upper $\mathrm{pH}$ range given

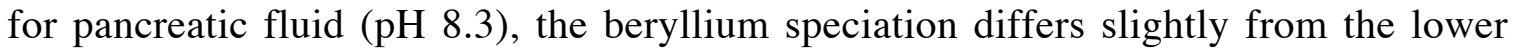
range such that the major species are $\mathrm{BeOH}^{+}(48.0 \%)$, aqueous $\mathrm{Be}(\mathrm{OH})_{2}(45.3 \%)$ and $\mathrm{Be}(\mathrm{OH})_{3}^{-}(3.9 \%)$ in both dilute and concentrated beryllium solutions. The lack of fluoride complex here could is due to the input data not having fluoride concentration levels. The speciation of beryllium in simulated bile is also somewhat similar to that of pancreatic fluid in that it does not change with changing beryllium concentration. At $\mathrm{pH} 7.8$ the beryllium-bile major speciation is shown in Figure 2-11 and predicted to be $\mathrm{BeOH}^{+}$ $(69.8 \%)$ and aqueous $\mathrm{Be}(\mathrm{OH})_{2}(27.5 \%)$ in both dilute and concentrated beryllium 
solutions. The solubility of solid $\mathrm{Be}(\mathrm{OH})_{2}$ in bile is shown to be $0.3 \mu \mathrm{M}$ at $\mathrm{pH} 7.8$, while in simulated pancreatic fluid the solubility is predicted to be $0.2 \mu \mathrm{M}$. Although other biological components of bile (e.g. steroid acids, bilirubin) are not considered in this model due to lack of thermodynamic data, their presence in bile may well impact the speciation and solubility of beryllium.
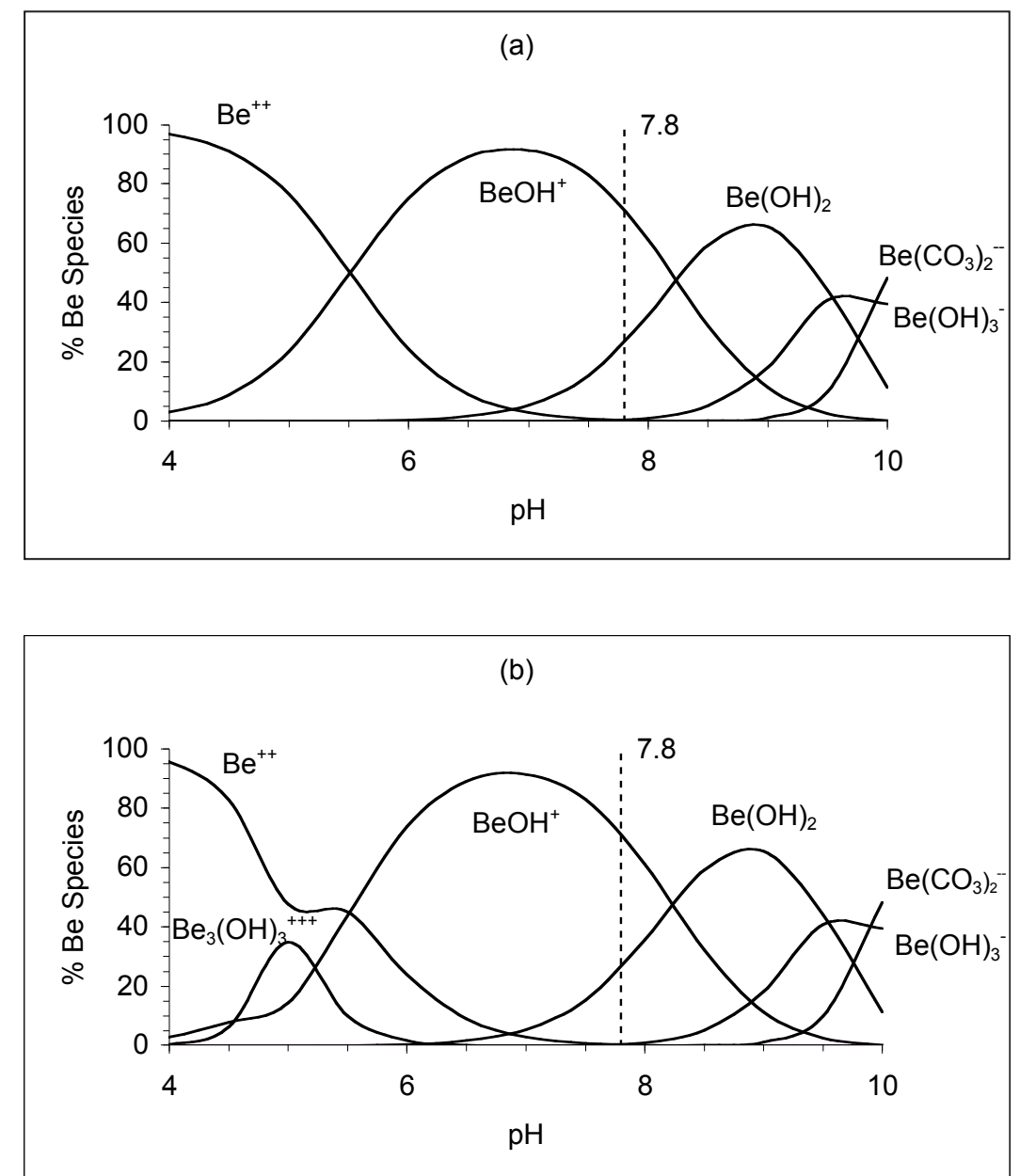

Figure 2-11. Beryllium speciation in simulated bile fluid, $[\mathrm{Be}]=($ a) $1 \mu \mathrm{M}$ and (b) $1 \mathrm{mM}$.

Chemical thermodynamic modeling of airway surface fluid (ASF) showed somewhat similar results for all the cases of interest. Examples of the speciation diagrams for $\mathrm{pH}$ variation in 'normal' and 'asthma' ASF are shown in Figure 2-12 and 2-13 respectively, while the exact speciation data at $\mathrm{pH} 7.0$ is detailed in Table 2-9. In all types of ASF studied, the modeled speciation results at $\mathrm{pH} 7.0$ for dilute beryllium where within \pm $0.2 \%$ of those for concentrated beryllium. Comparison of all 8 cases is difficult because the input data is not consistent throughout. The major species in the variety of ASF cases studied are $\mathrm{BeOH}^{+}(86.6-90.8 \%), \mathrm{Be}^{++}(4.0-5.4 \%)$, aqueous $\mathrm{Be}(\mathrm{OH})_{2}(3.9-4.7 \%)$ and aqueous $\mathrm{BeSO}_{4}(1.2-2.4 \%)$. 


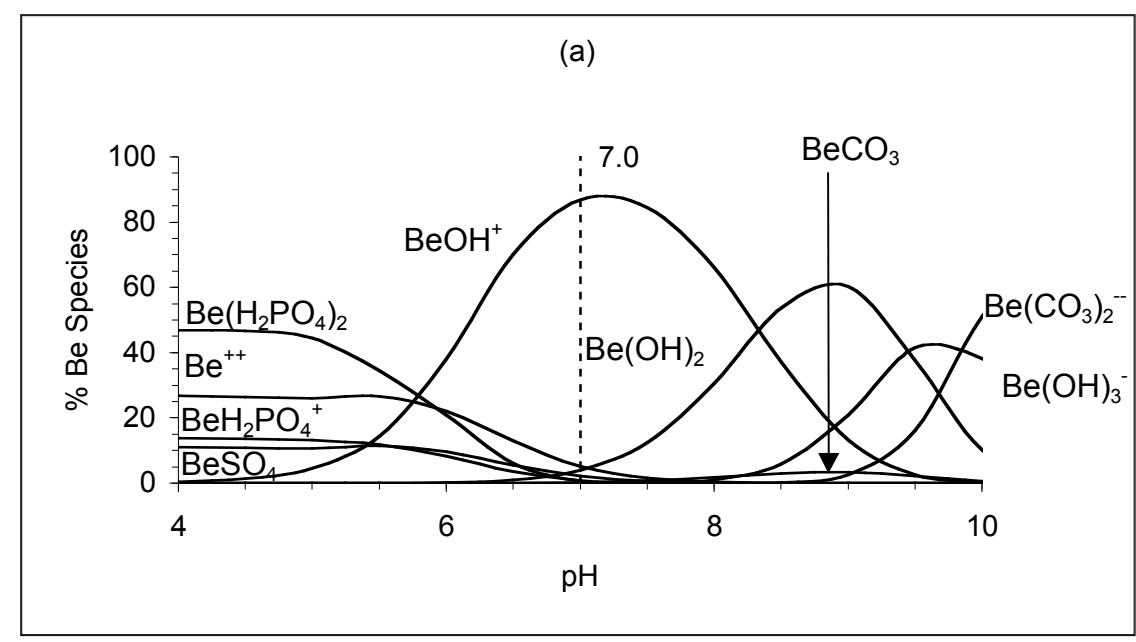

(b)

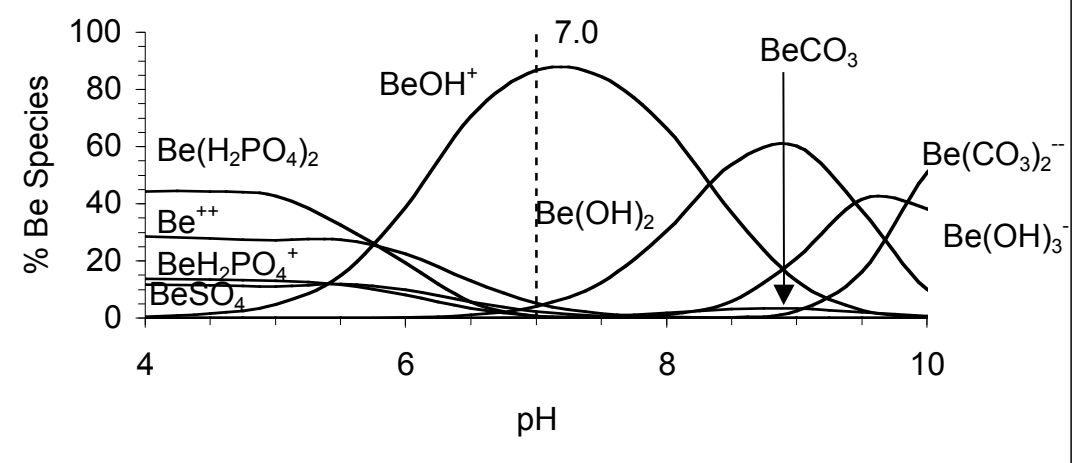

Figure 2-12. Beryllium speciation in simulated 'normal' surface airway fluid, $[\mathrm{Be}]=(a)$ $1 \mu M$ and $(b) 1 m M$

In cases where phosphate data was available and used in the model calculations, the total beryllium phosphate species ranged from 0.6-2.3\%. The formation of beryllium phosphate precipitate was shown to be unlikely, in favor of solid $\mathrm{Be}(\mathrm{OH})_{2}$ formation. However, one noteworthy result is that the solubility of beryllium is $13 \%$ less in ASF of a severe asthma patient than that of a normal patient. This can be attributed to the lower salt concentrations reported by Joris in asthma ASF (16). With a reduced chloride availability, more of the dissolved beryllium undergoes hydrolysis to form $\mathrm{BeOH}^{+}$and solid $\mathrm{Be}(\mathrm{OH})_{2}$, which at $\mathrm{pH} 7$ is more favorable than reaction with carbonate present from dissolved atmospheric carbon dioxide. The reduced ionic strength of the asthma ASF also changes the solubility and speciation. To investigate this, all ASF beryllium speciation/solubility models were recalculated at constant ionic strength (1molal), and compared with ASF models at unmodified ionic strength (with sulfate and phosphate removed for fair comparison). The results are shown graphically in Figure 2-14, and clearly show that the range of beryllium solubility is decreased when constant ionic strength is used. There still remains a noticeable (yet smaller) range for beryllium 
solubility and so we can assume that the difference between these ASF models is based upon both complexation and ionic strength.
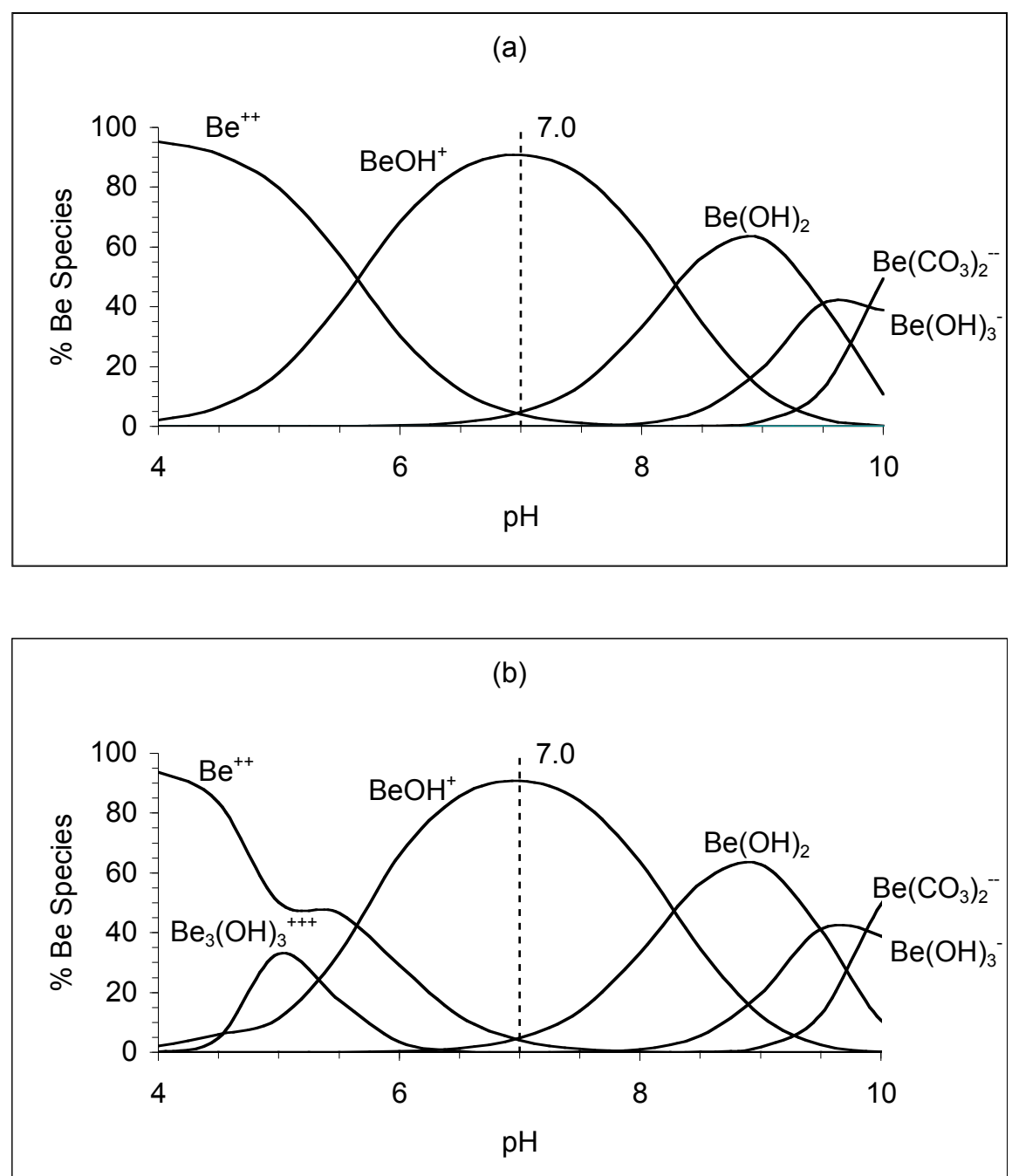

Figure 2-13. Beryllium speciation in simulated 'severe asthmatic' surface airway fluid, $[\mathrm{Be}]=(\mathrm{a}) 1 \mu \mathrm{M}$ and $(\mathrm{b}) \mathrm{ImM}$

Although strict comparison between 'normal' and asthma ASF cannot be performed because of a lack of cross reference of input data, the only important elemental component not detailed for severe asthma compared to 'normal' is that of sulfate, which only accounts for some $2.2 \%$ of the total dissolved beryllium speciation, while that of phosphate accounts for $1.4 \%$ and does not significantly affect the solubility of solid $\mathrm{Be}(\mathrm{OH})_{2}$. As stated earlier, eosinophil cationic protein (ECP) is known to be important in the human immune response system and in bronchial epithelium damage, especially in patients suffering from asthma and cystic fibrosis $(30,31)$. Furthermore, research by Halmerbauer et al (31) shows correlation between the concentration of ECP with calcium and magnesium ions, and inversely with chloride ions. It is not difficult to imagine a similar correlation with ECP and beryllium in patients with asthma or cystic fibrosis who 
may have since developed chronic beryllium disease. Future clinical studies of CBD patients should consider examination of ECP concentrations in bronchial lavage samples taken during medical evaluation for beryllium sensitization.

\begin{tabular}{|l|l|l|l|l|l|l|l|l|}
\hline Be Species & $($ a) & $($ b) & $(\mathbf{c})$ & $($ d) & $(\mathbf{e})$ & $(\mathbf{f})$ & $($ g) & (h) \\
\hline $\mathrm{Be}^{++}$ & 5.1 & 5.1 & 5.1 & 5.4 & 5.1 & 5.3 & 5.2 & 4.0 \\
\hline $\mathrm{BeOH}^{+}$ & 86.8 & 86.6 & 88.5 & 87.6 & 90.1 & 89.8 & 89.9 & 90.8 \\
\hline $\mathrm{Be}(\mathrm{OH})_{2}(\mathrm{aq})$ & 4.0 & 4.0 & 4.1 & 3.9 & 4.2 & 4.1 & 4.2 & 4.7 \\
\hline $\mathrm{Be}_{3}(\mathrm{OH})_{3}{ }^{+++}$ & 0.1 & 0.1 & 0.1 & 0.1 & 0.1 & 0.1 & 0.1 & 0.1 \\
\hline $\mathrm{BeSO}_{4}(\mathrm{aq})$ & 2.2 & 2.4 & 1.2 & - & - & - & - & - \\
\hline $\mathrm{BeCO}_{3}(\mathrm{aq})$ & 0.2 & 0.2 & 0.2 & 0.2 & 0.2 & 0.2 & 0.2 & 0.3 \\
\hline $\mathrm{BeCl}^{+}$ & 0.2 & 0.2 & 0.3 & 0.4 & 0.3 & 0.4 & 0.4 & 0.1 \\
\hline $\mathrm{BeH}_{2} \mathrm{PO}_{4}^{+}$ & 0.7 & 0.7 & 0.4 & 1.0 & - & - & - & - \\
\hline $\left.\mathrm{Be}_{2} \mathrm{H}_{2} \mathrm{PO}_{4}\right)_{2}(\mathrm{aq})$ & 0.7 & 0.7 & 0.2 & 1.3 & - & - & - & - \\
\hline $\mathrm{Be} \mathrm{Solubility,} \mathrm{mM}$ & 1.92 & 1.92 & 1.87 & 1.93 & 1.82 & 1.86 & 1.84 & 1.67 \\
\hline
\end{tabular}

Table 2-9. Percentage Beryllium Speciation at pH7 in Airway Surface Fluid, \%. Speciation of beryllium in ASF of patients during the following conditions: (a) Normal,

(b) post antichlolinergic pretreatment, $(c)$ post-benzodiazepine pretreatment, $(d)$ hypersecretory, $(e)$ sustained airway irritation, $(f)$ acute airway infection, $(g)$ cystic fibrosis and $(h)$ severe asthma.

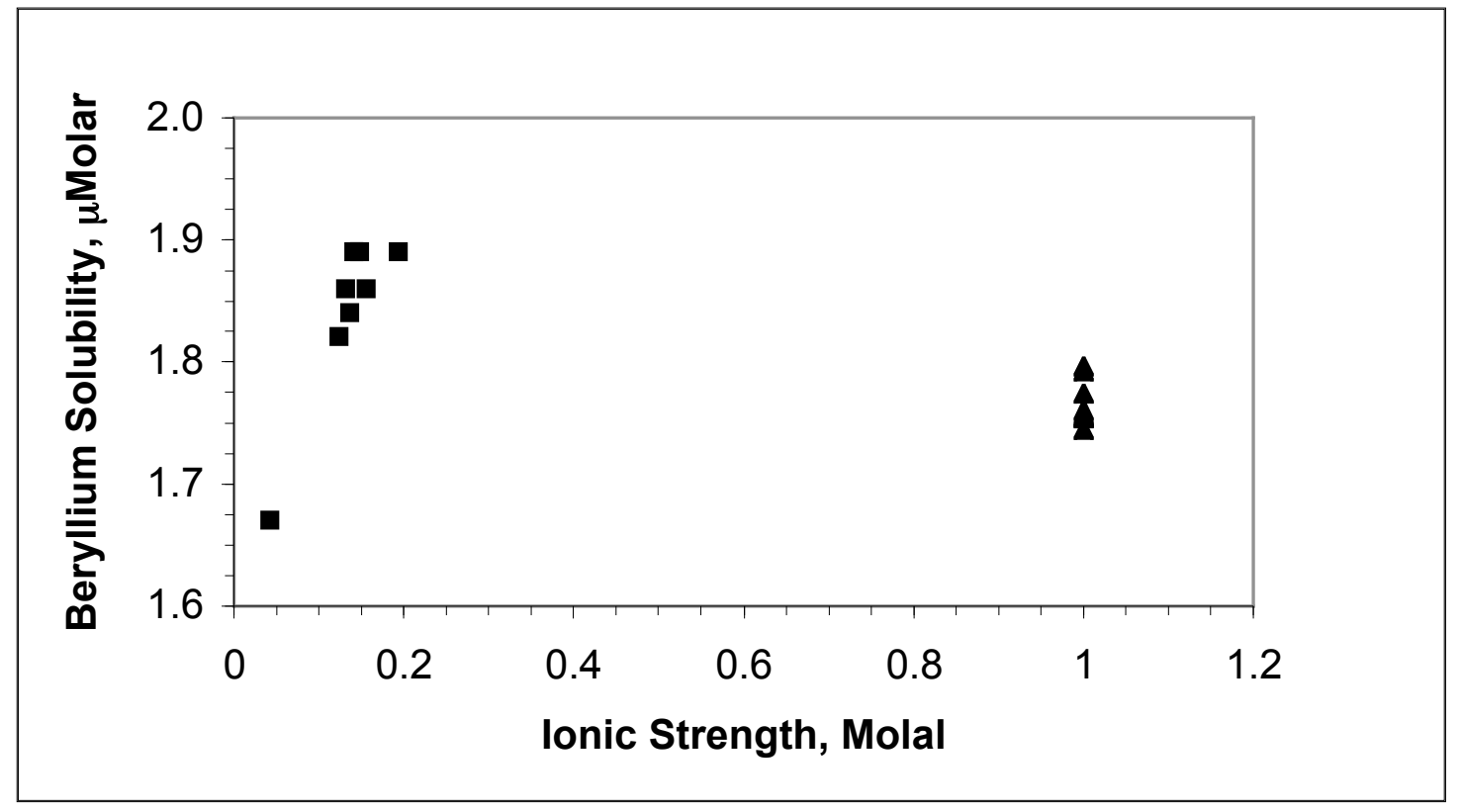

Figure 2-14. Ionic strength effects on the solubility of solid $\mathrm{Be}(\mathrm{OH})_{2}$ in surface airway fluids. Legend: Beryllium solubility (micromolar, umol/l) when correct ionic strength for each system is used without phosphate or sulfate complexation ( $\boldsymbol{\square})$, Be solubility when adjusted ionic strength of 1 molal ( $\mathrm{mol} / \mathrm{kg})$ is used ( $\boldsymbol{\Lambda})$. 


\subsection{Conclusions}

The predicted beryllium speciation and solubility in simulated biological fluids is influenced by the $\mathrm{pH}$, beryllium concentration, body fluid composition and ionic strength of each system. Modeled results suggest that beryllium solubility inside the cell can be several times greater than that outside the cell in plasma or interstitial fluid depending upon the $\mathrm{pH}$ of ICF, and that beryllium may precipitate as phosphate and/or hydroxide inside the cell. Our results also suggest that beryllium precipitation outside the cell in extracellular fluid can occur and leads to the formation of solid beryllium hydroxide. The chemistry of beryllium in urine and saliva is dominated by the high stability of beryllium hydroxyfluoride and allows the possible high limit of solubility in urine to be calculated, while the solubility of beryllium in bile and pancreatic fluid is shown to be very low. In simulated sweat the results show a wide range in beryllium solubility based upon the range of $\mathrm{pH}$ given for sweat solutions, but provide supportive evidence that skin absorption may prove an effective route of absorption for beryllium handlers. In gastric juice, the results clearly show the "competition chemistry" for beryllium between fluoride, chloride and phosphate, and allow an assessment of the feasibility of beryllium phosphate precipitation in the intestine. The variation in beryllium chemistry and solubility in a number of airway surface fluids was found to be small, except in the case of asthmatic ASF, which is low in ionic constituents.

In summary the use of chemical thermodynamic models to examine the biochemistry of beryllium in human body fluids can aid the understanding of beryllium speciation, solubility and distribution in the body. This knowledge can, when combined with current research and findings in immunology and genetics, lead to a better understanding of the beryllium toxicology and pathophysiology of CBD, the feasibility of a bioassay for beryllium and the potential for using chelators to remove beryllium lung/body burden in heavily exposed persons. Further work will be performed to experimentally verify the data obtained by thermodynamic modeling. The modeling presented in this work assumes a thermodynamic equilibrium state throughout all reactions and ions in stable homogeneous biological fluids can be assumed to be in equilibrium, given that exposures and body burden are felt to be chronic. The reaction kinetics of ion interactions are based on the probability of ions existing in the same space at the same time, and the rate of electron transfer to form a chemical bond (be it electrostatic or covalent), followed by the subsequent structural rearrangement of atoms in space to yield the most stable structure. Such kinetics can be assumed to be almost instantaneous and therefore do not affect the original assumption of an equilibrium state. However, much larger kinetic effects are seen in heterogeneous systems, and especially in the reaction between solids and liquids. Here the kinetics are dependent on breaking the bonds in the O-Be-O lattice structure of the beryllium oxide surface layer on a beryllium particle. Depending on the mineral, and the chemical and physical environment, such reactions can occur over time periods ranging from seconds to thousands of years. It is however fair to assume that the extreme outer surface boundary between fluid and a particle is in thermodynamic equilibrium. Ideally, experimental work can be done to validate these assumptions.

It is also acknowledged that some biological fluids are subject to rapid change, and that such changes may affect the beryllium speciation and solubility. Age, prolonged illness, 
prescribed medications, environment, diet and lifestyle are all factors influencing the chemical and electrical balance in biological fluids. However, homeostasis in fluids and cells acts to minimize such changes. Small fluctuations in $\mathrm{pH}, \mathrm{pCO}_{2}$, fluoride, chloride, phosphate and ionic strength might lead to a change in beryllium speciation, solubility and solubility-limiting phases. Changes in the sodium and potassium concentrations in fluids act only to alter the ionic strength and indirectly control beryllium chemistry. The results presented in this work provide an understanding of beryllium chemistry in "typical" biological fluids in which a range of $\mathrm{pH}$ values are quoted. Changes in fluid composition may affect beryllium the biochemistry and may be understood by examining the speciation diagrams (Figures 2-3 through 2-13) and for example show that increasing $\mathrm{pCO}_{2}$ in ICF and ESF would lead to an increase in beryllium carbonate species and an increase in the beryllium phosphate / hydroxide solubility.

The modeling reported in this article is limited to elemental speciation and no thermodynamic assessment of beryllium binding to proteins or intracellular constituents has been made. Chemical thermodynamic data for the reaction of metals with such biologically important components is currently lacking, but as the underlying biochemistry of the cell-mediated immune response to beryllium is better characterized, these biological components could be potentially added to the model. In this way, the feasibility of practical medical approaches such as biological monitoring and chelation therapy can be more thoroughly explored prior to animal and human studies. Furthermore, the thermodynamic approach described above, when combined with experimental data, can be applied to understanding the toxicology of other metals of industrial and medical importance which are candidates for biological monitoring or chelation treatment.

\subsection{References}

1. Hoover, M. D., Castorina, B.T., Finch, G. L. and Rothenberg, S. J. (1988) Determination of the oxide layer thickness on beryllium metal particles. Am. Ind. Hyg. Assoc. J. 50, 550-553.

2. Musket, R. G. (1999) Oxidation of beryllium in ambient air. LLNL Report UCRL-JC-136563.

3. Lee, J. D. (1991) Concise Inorganic Chemistry, 4th Ed. pp.330-333. Chapman \& Hall, London.

4. Newman, L. (2002) Personal Communication, June.

5. Eisenbud, M. \& Guilmette, R. A (2000) Is there a role for chelation in the management of chronic beryllium disease? Technology, 7, 213-222.

6. Sprince, N. L., Kazemi, H., Hardy, L. (1976) Current problems of differentiating between beryllium disease and sarcoidosis. Ann. NY Acad. Sci., 278, 654-664.

7. Longcope, W. T., Freiman, D. G. (1952) A study of sarcoidosis. Medicine 31, 1-132.

8. Smith, R. M. and Martell, A. E. (1982) Critical Stability Constants, vol.5. Plenum Press, New York.

9. Motekaitis, R. J. (2001) NIST Standard Reference Database 46 ver.6. - NIST Critically Selected Stability Constants of Metal Complexes (Martell, A. E. and Smith, R. M., Eds).

10. Spahiu, K. (2002) Phase II of the NEA TDB Project and Some Lessons Learned from the Use of Phase I Data. In The Use of Thermodynamic Databases in Performance Assessment - Workshop Proceedings. NEA-OECD, Paris, France.

11. Allison, J. D., Novo-Gradac, K. J. and Brown, D. S.(1998) MINTEQA2 ver.4. - A Geochemical Assessment Model for Environmental Systems. Environmental Research Laboratory, Office of Research \& Development, United States Environmental Protection Agency, Athens, Georgia.

12. Iyengar, G. V., Kollmer, W. E. and Bowen, H. J. M. (1978) The Elemental Composition of Human Tissues and Body Fluids. Verlag Chemie, Weinheim. 
13. Guyton, A. C. and Hall, J. E. (2000) Textbook of Medical Physiology. 10th Ed. p.267. W. B. Saunders Company, Philadelphia

14. Guyton, A. C. and Hall, J. E. (2000) Textbook of medical Physiology. 10th Ed. p.346-7. W. B. Saunders Company, Philadelphia.

15. Guyton, A. C. and Hall, J. E. (2000) Textbook of medical Physiology. 10th Ed. p.740. W. B. Saunders Company, Philadelphia.

16. Livingston, R. B. (1985) Neurophysiology. In Best \& Taylors Physiological Basis of Medical Practice (West, J. B. Ed) 11th Ed. p.1229. Williams \& Wilkins, Baltimore.

17. Joris, L., Dab, I. And Quinton, P. M. (1993) Elemental composition of human airway surface fluid in healthy and diseased airways. Am. Rev. Respir. Dis. 148, 1633-1637.

18. Matthews, L. W., Spector, S., Lemm, J. and Potter, J. L. (1963) Studies on pulmonary secretions I: The overall chemical composition of pulmonary secretions from patients with cystic fibrosis, bronchiectasis and laryngectomy. Am. Rev. Respir. Dis. 88, 199-204.

19. Potter, J. L., Matthews, L. W., Spector, S. and Lemm, J. (1967) Studies on pulmonary secretions II: Osmolality and the ionic environment of pulmonary secretions from patients with cystic fibrosis, bronchiectasis and laryngectomy. Am. Rev. Respir. Dis. 96, 83-87.

20. Quinton, P. M. (2002) Personal Communication, August.

21. Chukhlantsev, V. G. \& Alyamovskaya, K. V. (1962) Solubility products of uranyl, beryllium and cerium phosphates. Chem. Abs, 56, 993.

22. Naumov, G. B., Ryzhenko, B. N. and Khodakovsky, I.L. (1974) Handbook of Thermodynamic Data. USGS-WRD-74-001 U.S. Geological Survey, Water Resources Division, Springfield, VA.

23. Wood, S. A (1992) Theoretical prediction of speciation and solubility of beryllium in hydrothermal solutions to $300 \mathrm{oC}$ at saturated vapor pressure: application to bertrandite / phenakite deposits. Ore Geology Rev. 7, 249-278.

24. Watha, J. C. Lockwood, P. E., Noda, M., Nelson, S. K. and Mettenburg, D. J. (2002) Effect of tooth brushing on the toxicity of casting alloys. J. Prosthetic Dent., 87, 94-98.

25. Horng, C. J., Horng, P. H., Lin, S. C., Tsai, J. L., Lin, S. R. and Tzeng, C. C. (2002) Determination of urinary beryllium, arsenic and selenium in steel production workers. Biol. Trace Elem. Res. 88, 235-246.

26. Reeves, A. L. (1991) Experimental pathology. In Beryllium: Biomedical and Environmental Aspects. (Rossman, M. D., Preuss, O. P. and Powers, M. B) Lippincott, Williams and Wilkins, 1991 Philadelphia, PA.

27. Tinkle, S. (2002) Personal Communication, June.

28. Belman, S. (1969) Beryllium binding of epidermal constituents. J. Occup. Med., 11, 175-183.

29. Gmelin, L. (1996) Handbook of Inorganic and Organometallic Chemistry. System 26 - Be, Suppl. Vol B4, Compounds with carbon to francium. 8th Edition, Springer-Verlag, Berlin 1996.

30. Dosanjh, A., Gamst, A., Phillipson, J. and Broughton, A. (1996) Elevated serum eosinophil cationic protein levels in cystic fibrosis, pediatric asthma, and bronchiolitis. Pediatric Asthma Allergy \& Immunology, 10, 169-173.

31. Halmerbauer, G., Arri, S., Schierl, M., Strauch, E., and Koller, D. Y. (2000) The relationship of eosinophil granule proteins to ions in the sputum of patients with cystic fibrosis. Clinical and Experimental Allergy, 30, 1771-1776. 
3

Beryllium Chelation 


\section{Beryllium Chelation}

\subsection{Chemical Thermodynamic Modeling}

As already discussed in Chapters 1 and 2, chelation therapy could provide a useful treatment for the currently incurable Chronic Beryllium Disease. However, such chelation therapy would have to be effective in dissolving and binding beryllium, selective in binding only beryllium, and relatively non-toxic. Just as chemical thermodynamic modeling can be used to study the chemistry (speciation and solubility) of beryllium in biological fluids and environmental systems, so it can be used to study the chelation of beryllium.

\subsubsection{Initial Screening}

Over 200 potential chelators in the NIST Critically Reviewed Thermodynamic Database were screened and ranked on their ability to both dissolve beryllium and maintain binding over a 'reasonable' $\mathrm{pH}$ range typically seen in the body. Modeling was performed again using the MINTEQA2 code. A sample set of ten examples are shown below. Solubility data is plotted in a contour format to show the effect of both $\mathrm{pH}$ and chelator concentration (pChelator $=-\log 10[$ Chelator]) on beryllium solubility. Speciation diagrams are plotted showing the effect of chelator concentration on beryllium binding, and hence examining the effectiveness and selectiveness of the chelator. For all of the examples shown below, the electrolyte chemical composition was based on simulated interstitial fluid. 


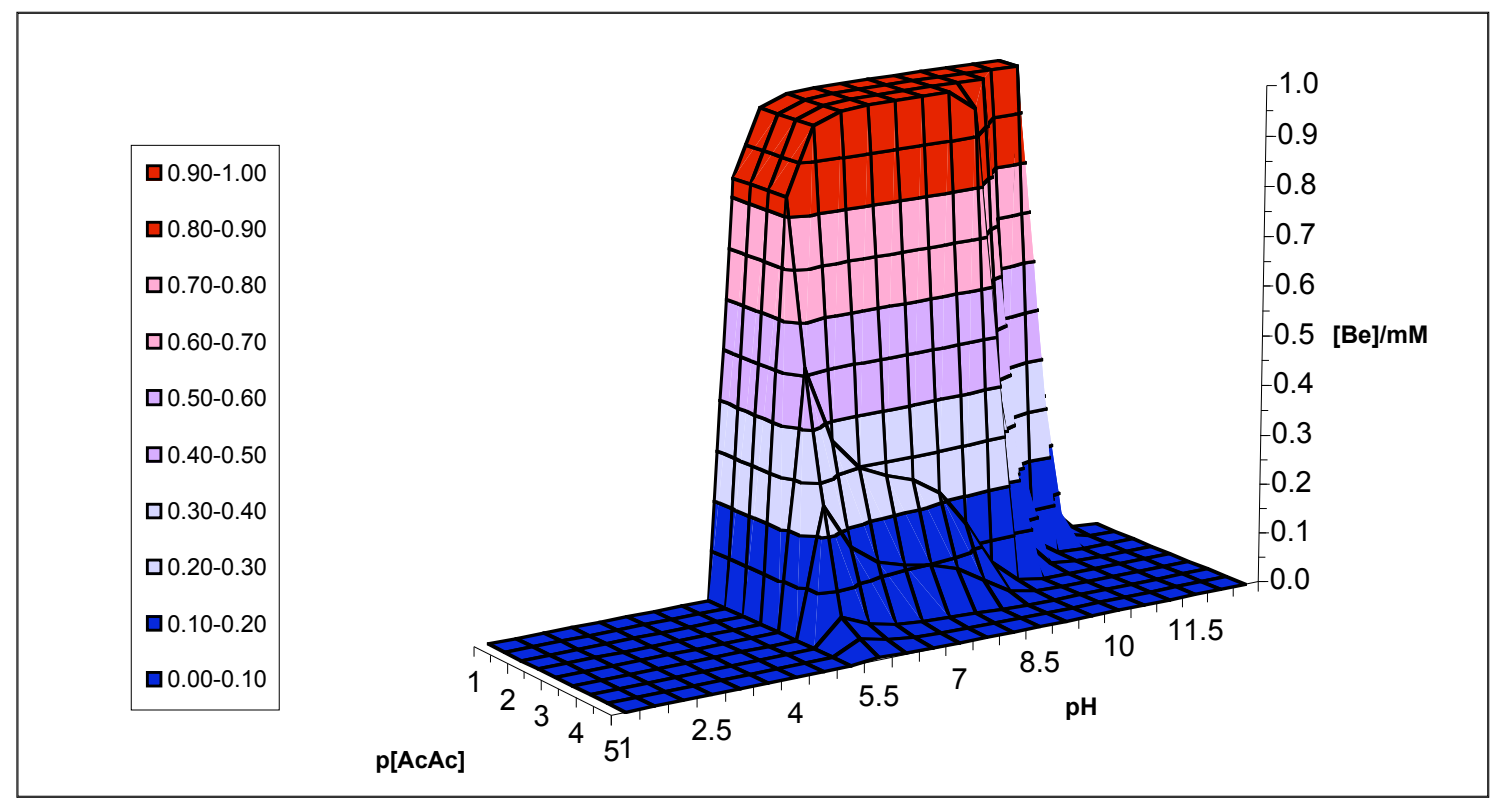

Figure 3-1. Effect of AcAc and pH on beryllium solubility in simulated interstitial fluid.

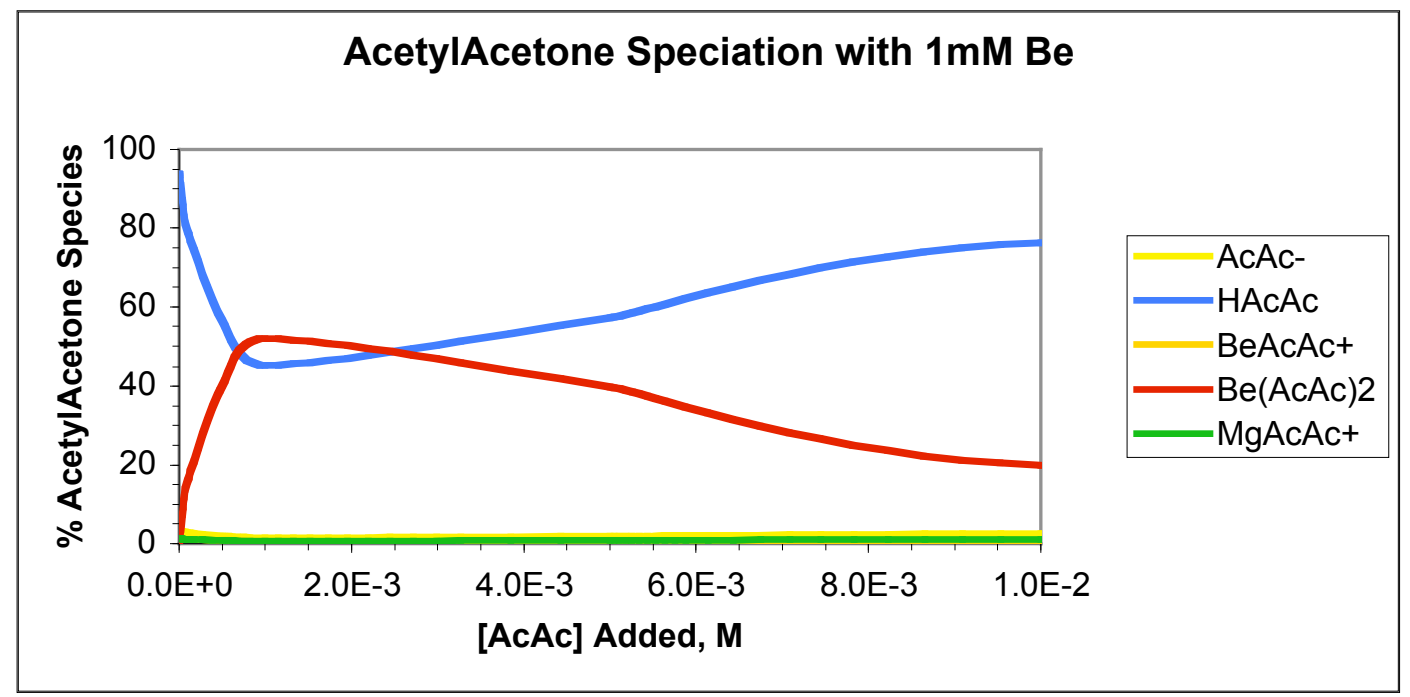

Figure 3-2. AcAc speciation in interstitial fluid with added beryllium 


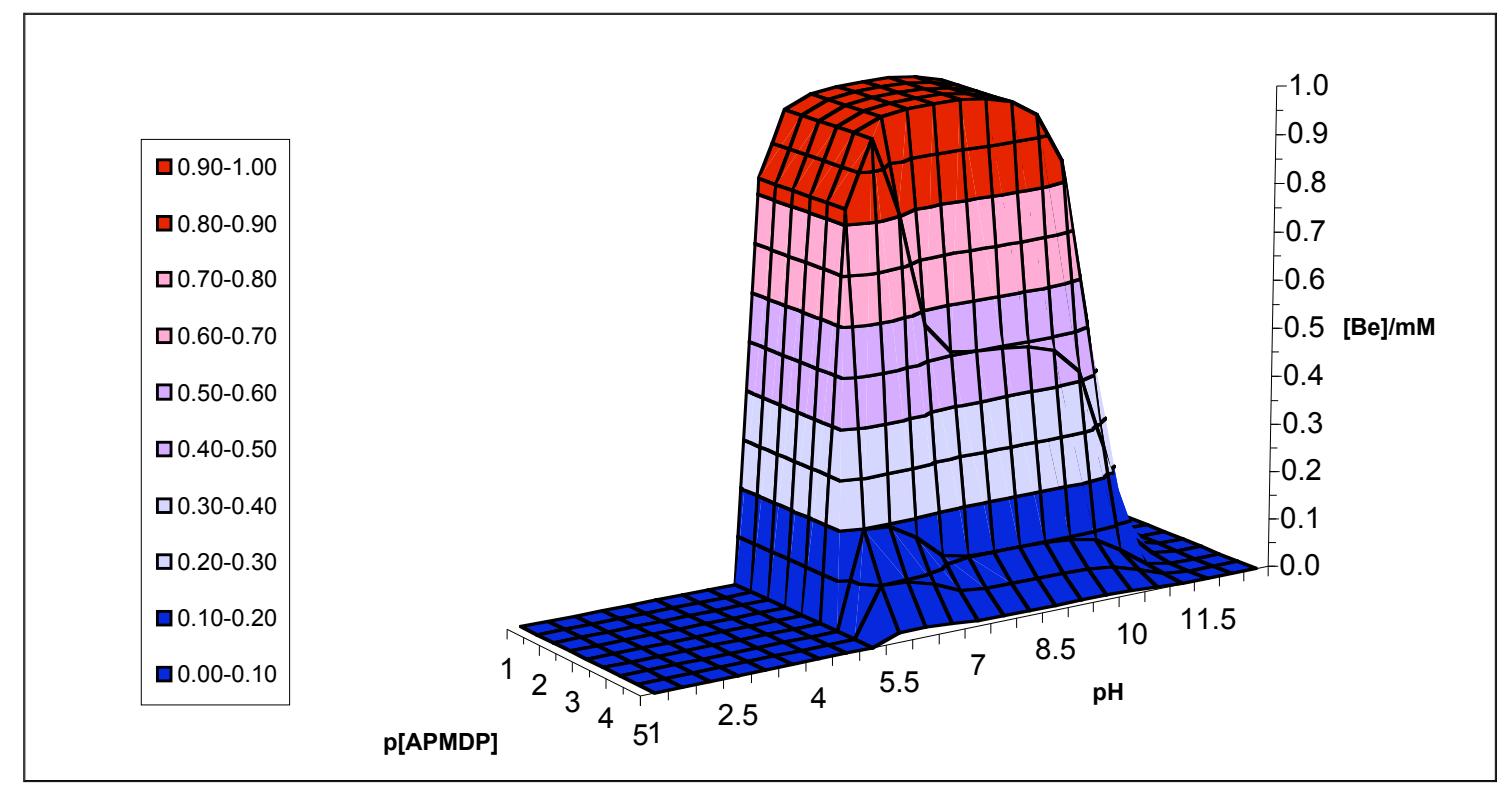

Figure 3-3. Effect of APMDP and pH on beryllium solubility in simulated interstitial fluid.

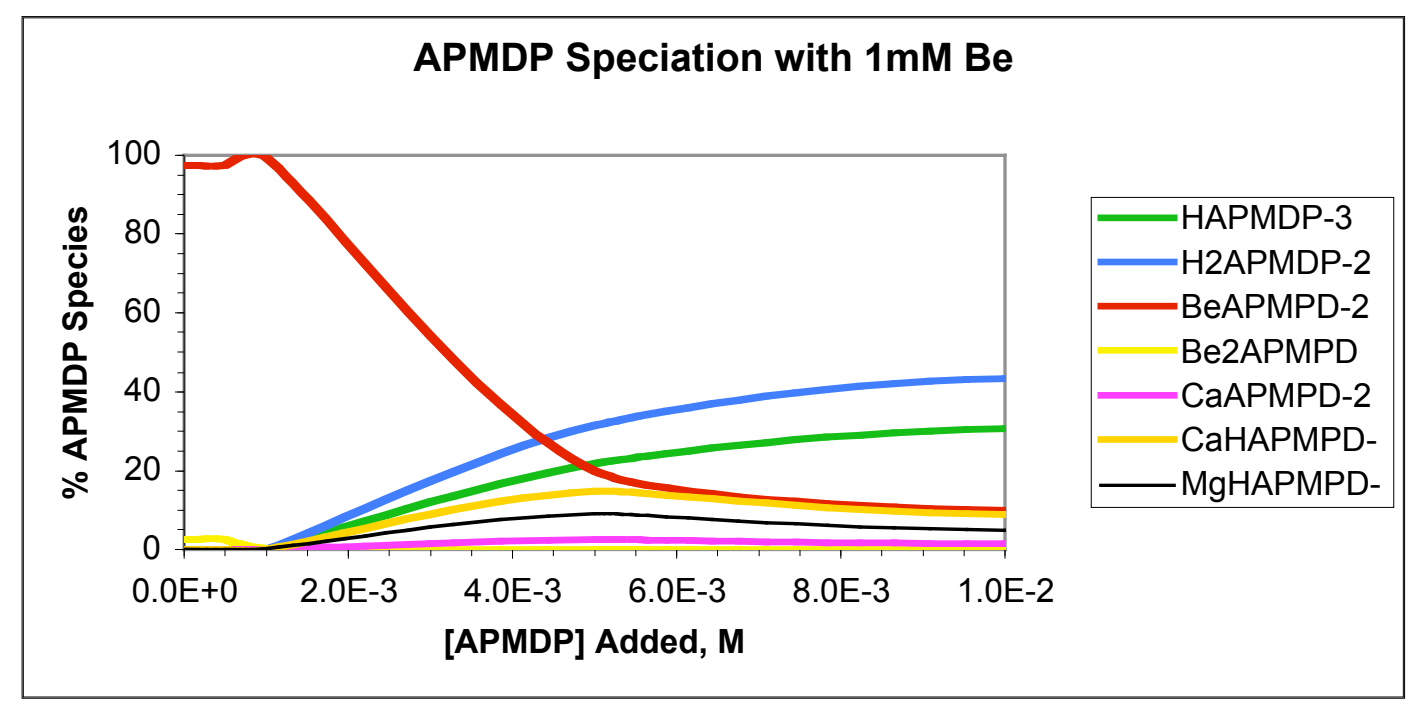

Figure 3-4. APMDP speciation in interstitial fluid with added beryllium 


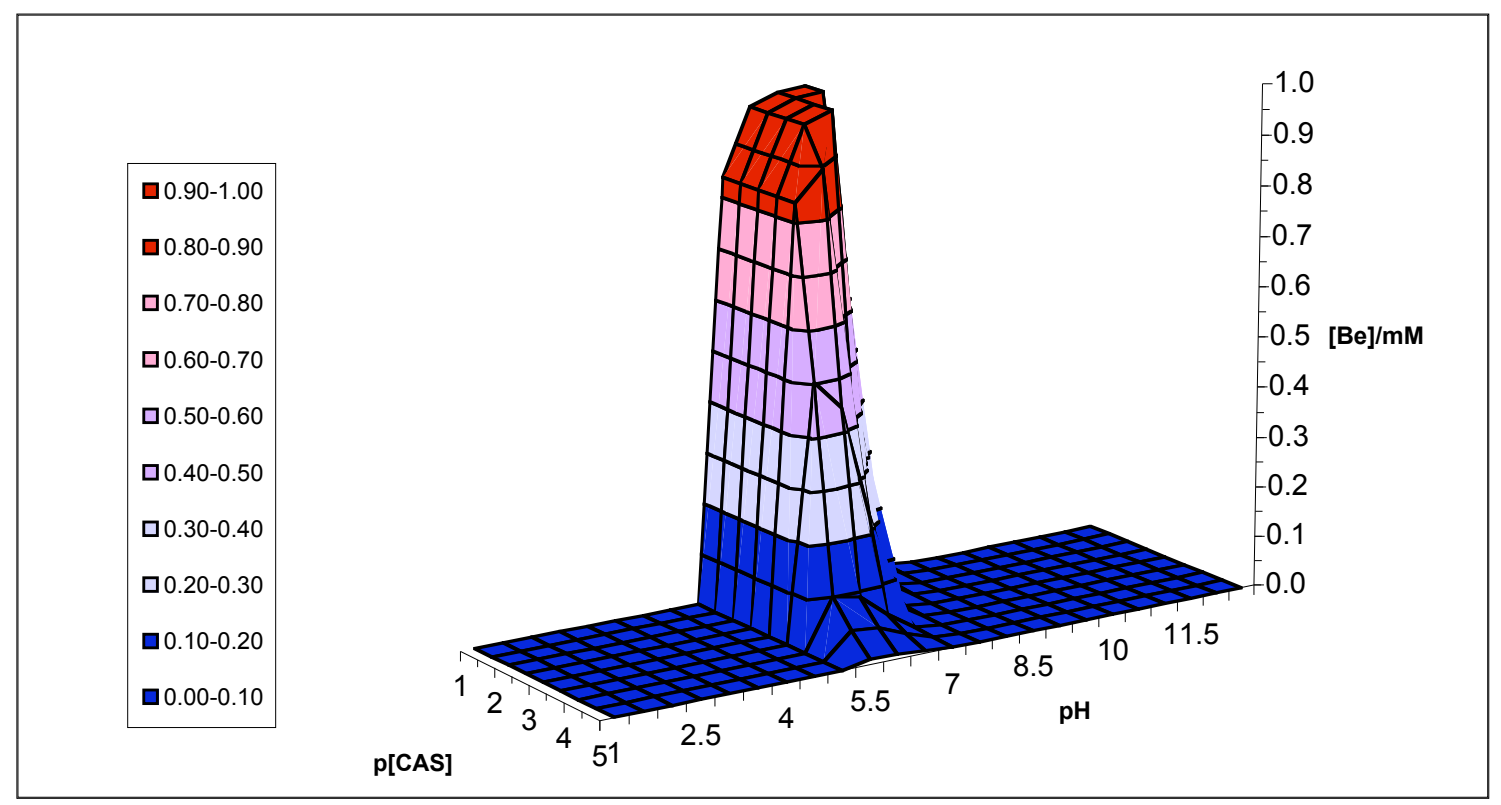

Figure 3-5. Effect of CAS and pH on beryllium solubility in simulated interstitial fluid

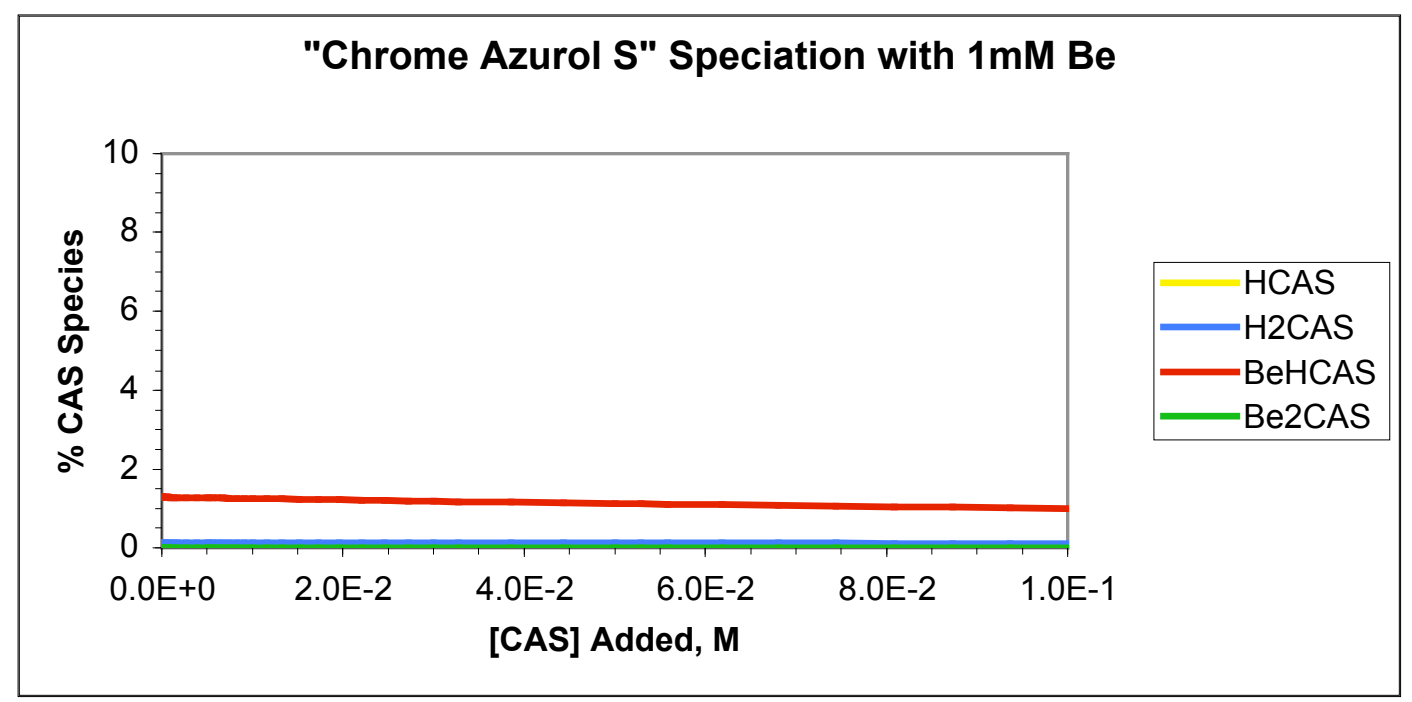

Figure 3-6. CAS speciation in interstitial fluid with added beryllium 


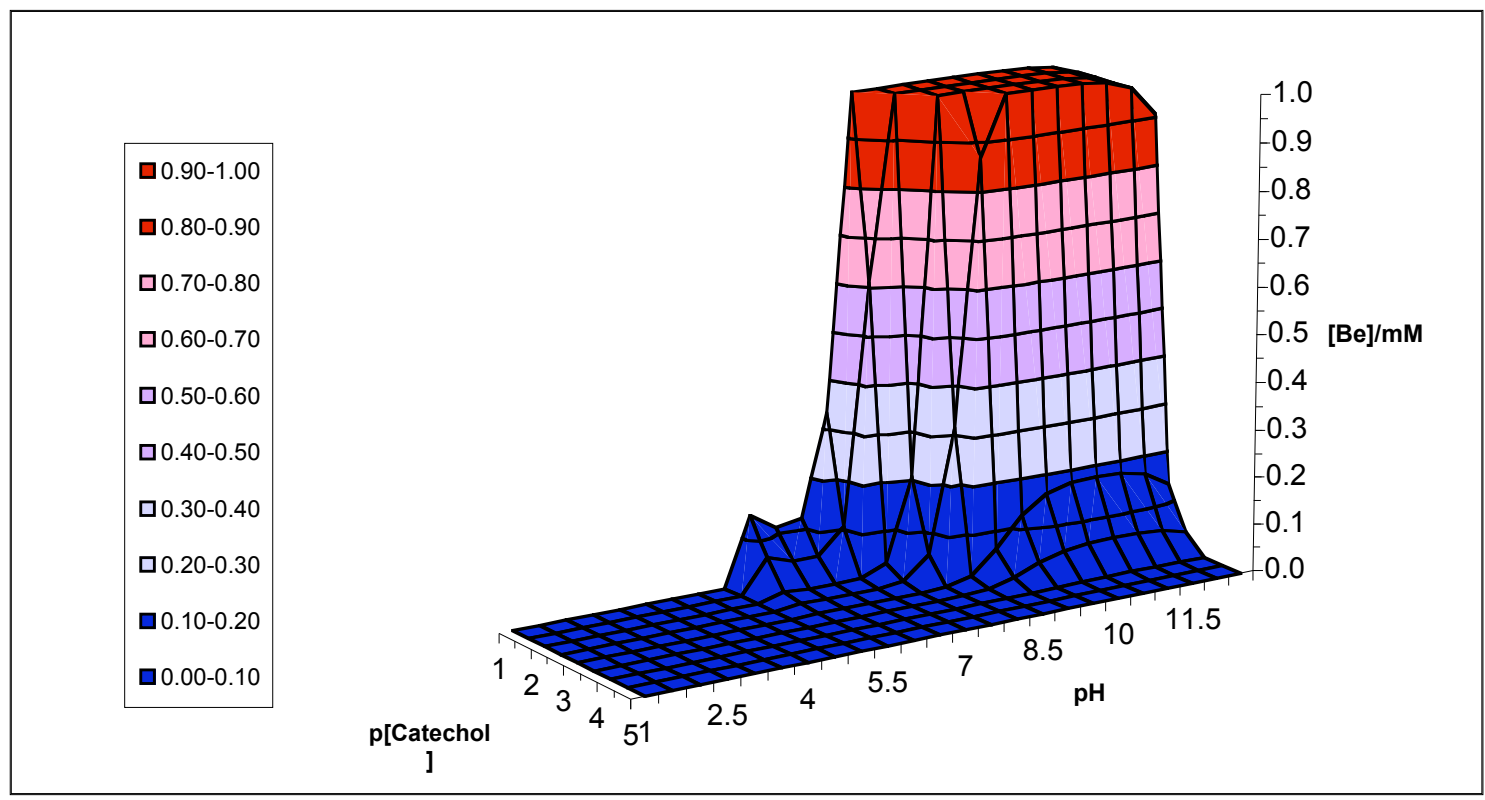

Figure 3-7. Effect of Catechol and $\mathrm{pH}$ on beryllium solubility in simulated interstitial fluid.

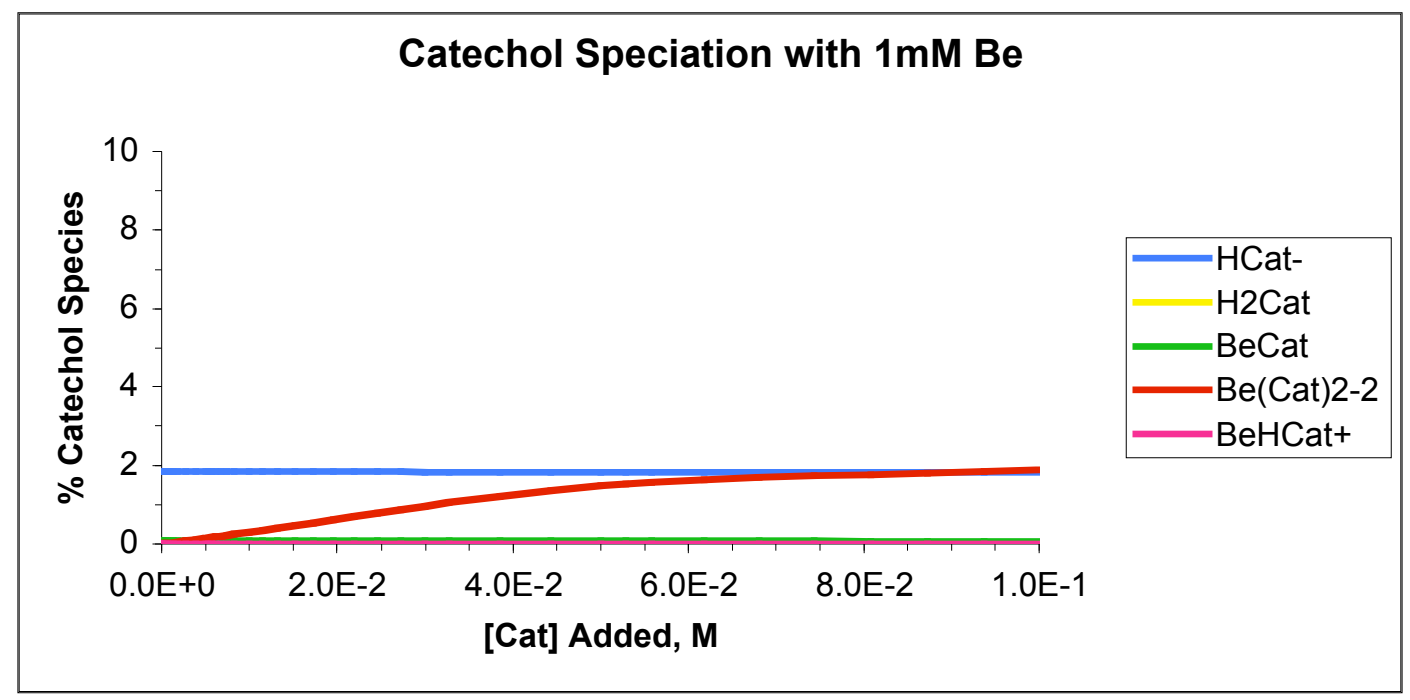

Figure 3-8. Catechol speciation in interstitial fluid with added beryllium 


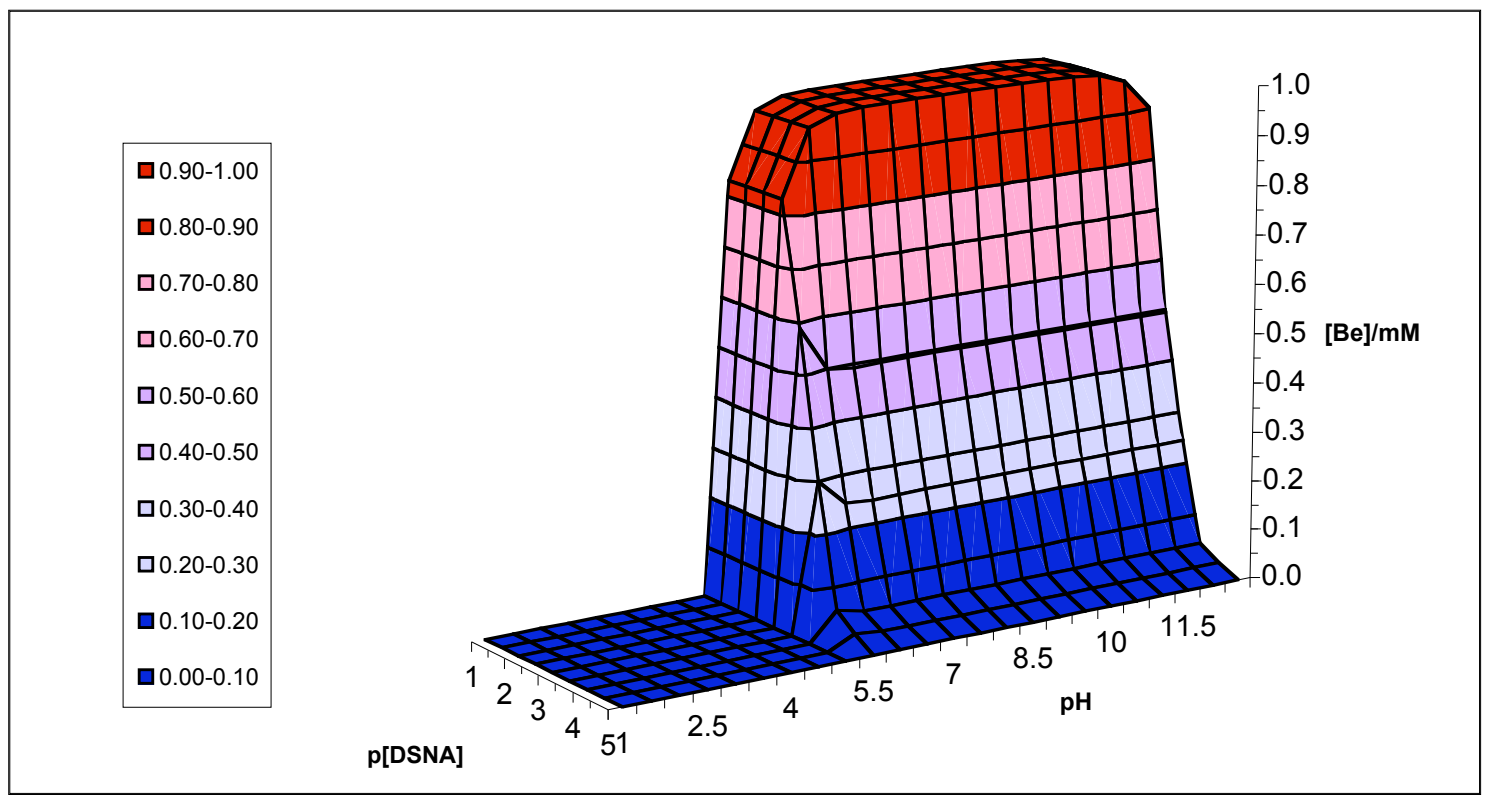

Figure 3-9. Effect of DSNA and pH on beryllium solubility in simulated interstitial fluid.

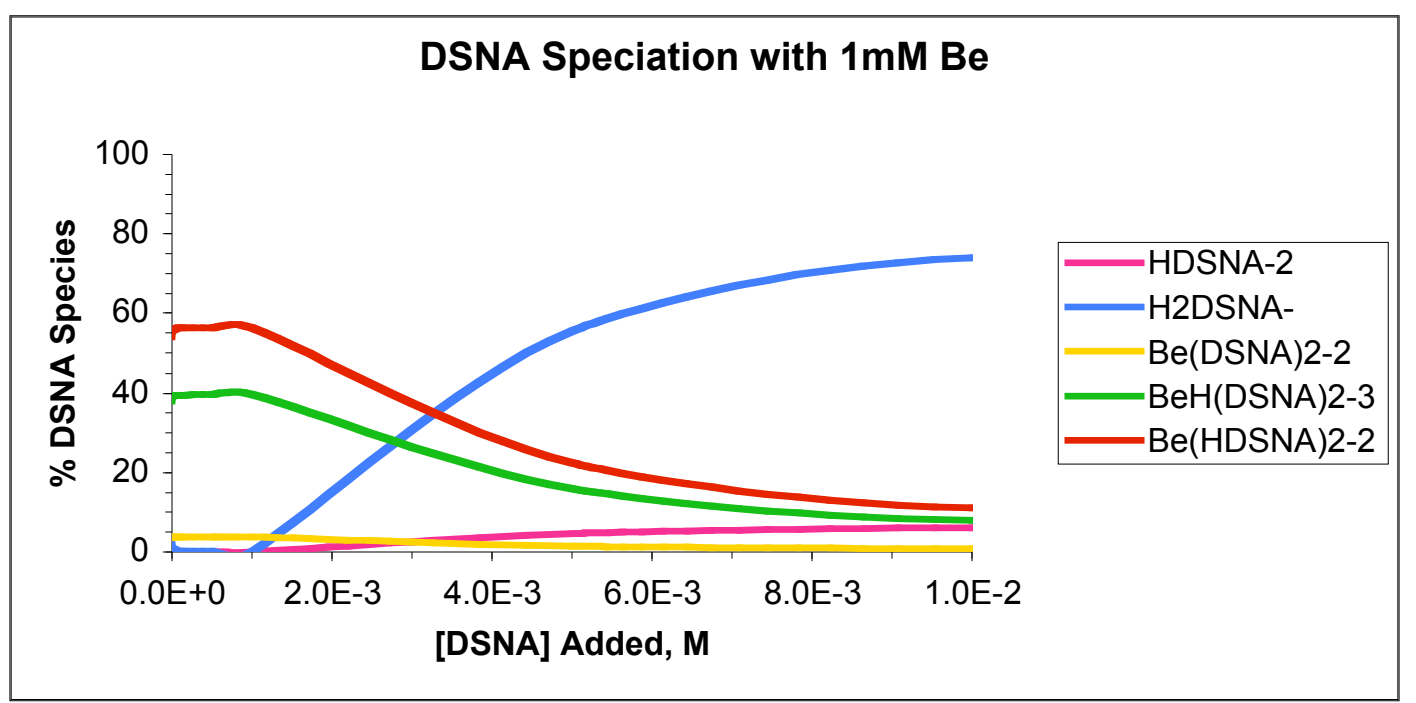

Figure 3-10. DSNA speciation in interstitial fluid with added beryllium 


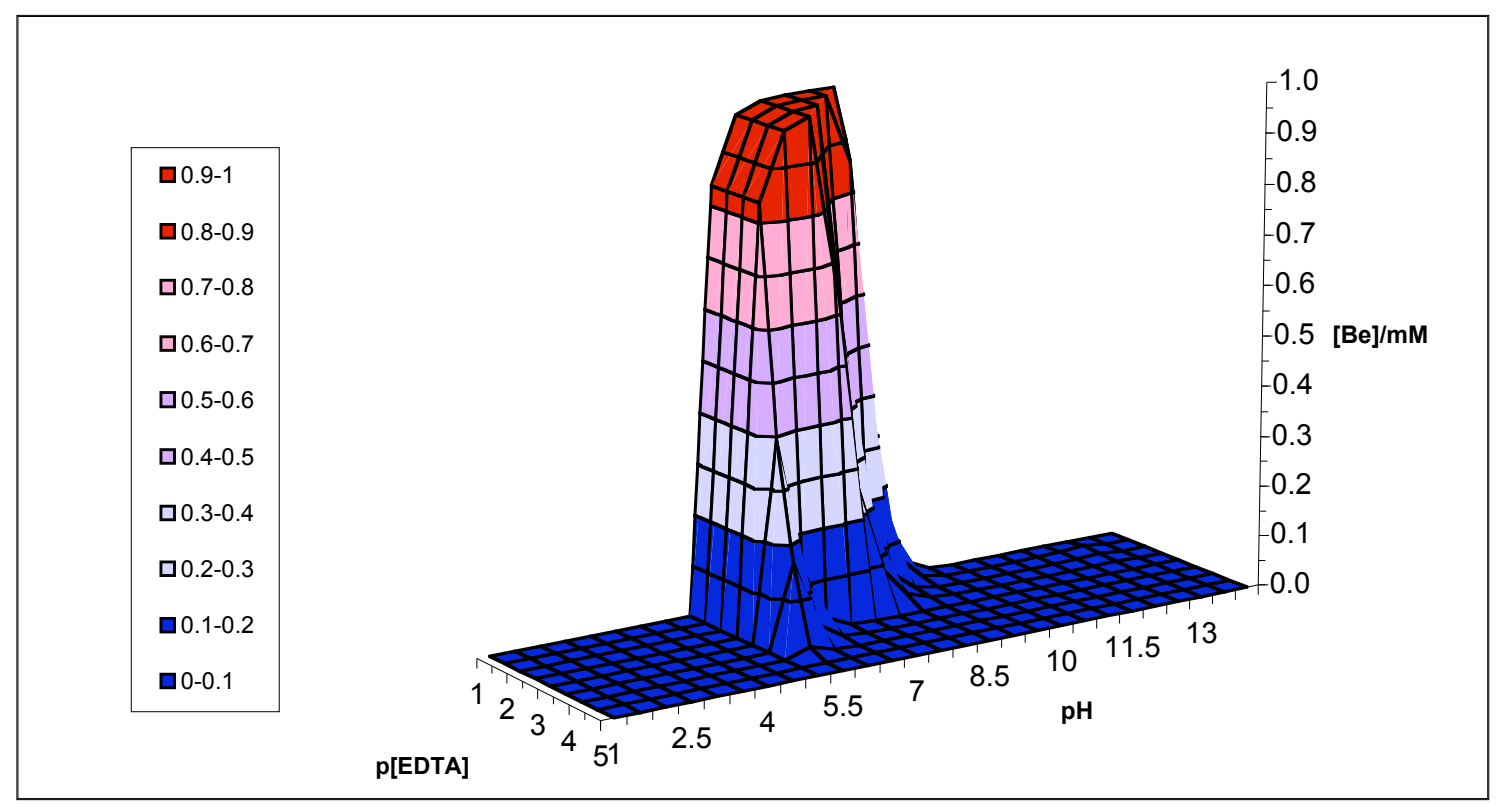

Figure 3-11. Effect of EDTA and pH on beryllium solubility in simulated interstitial fluid.

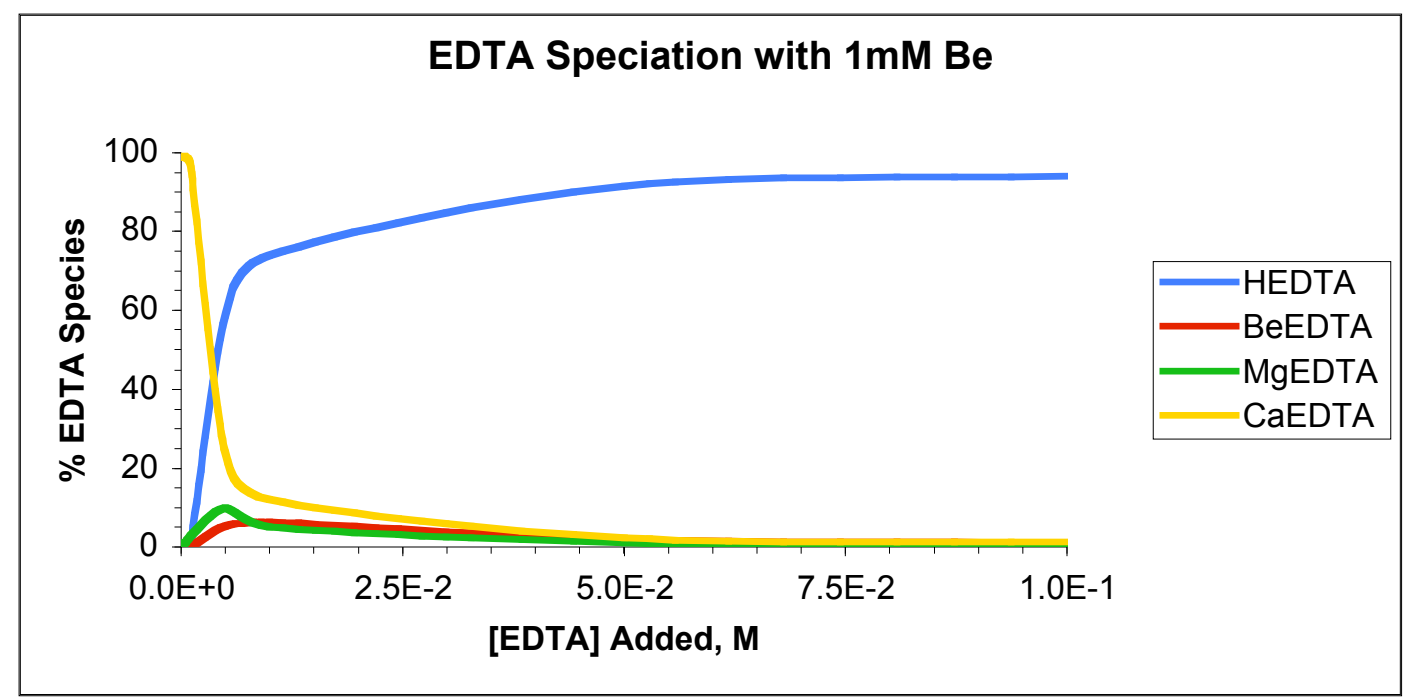

Figure 3-12. EDTA speciation in interstitial fluid with added beryllium 


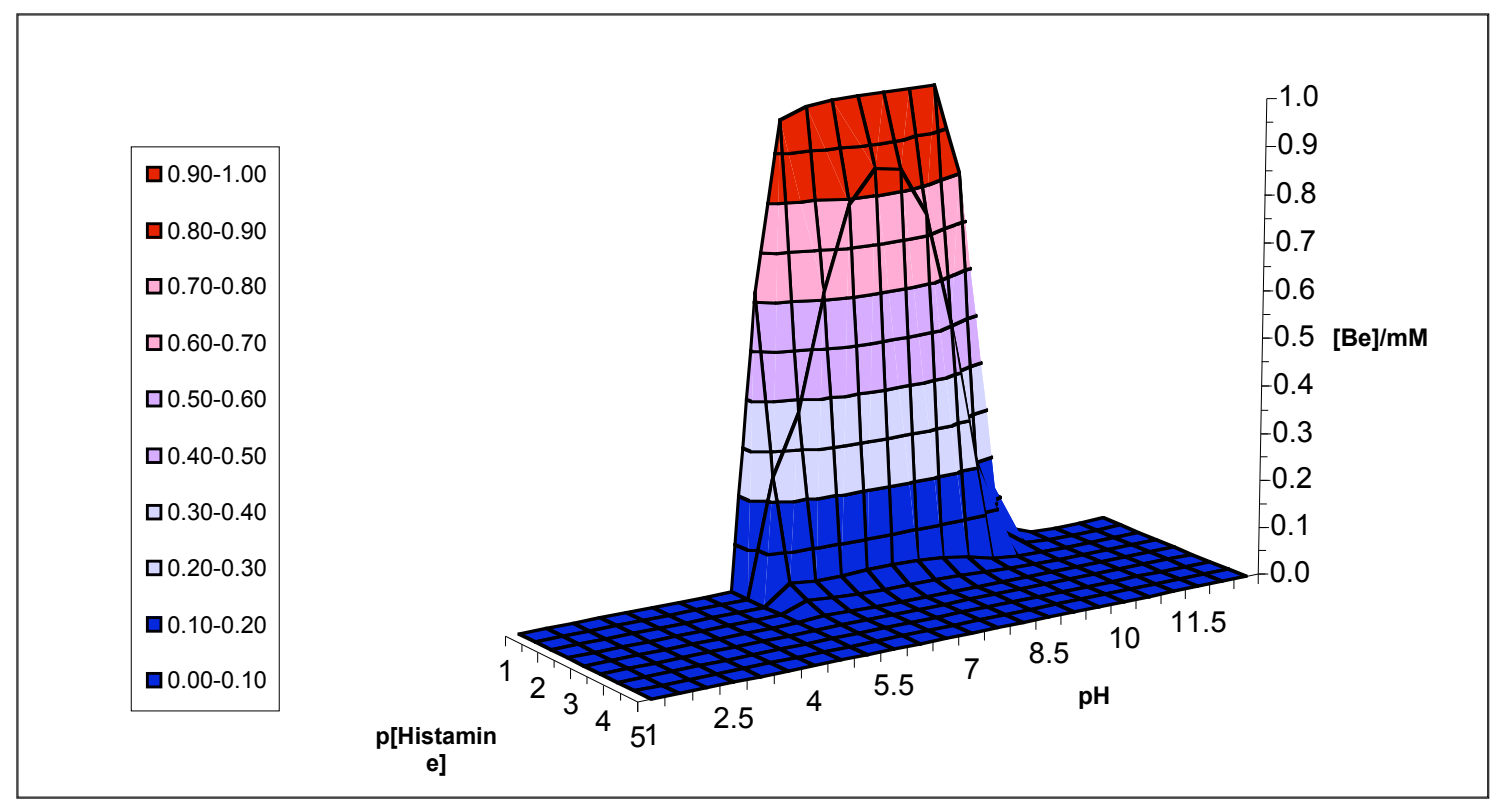

Figure 3-13. Effect of Histamine and pH on beryllium solubility in simulated interstitial fluid.

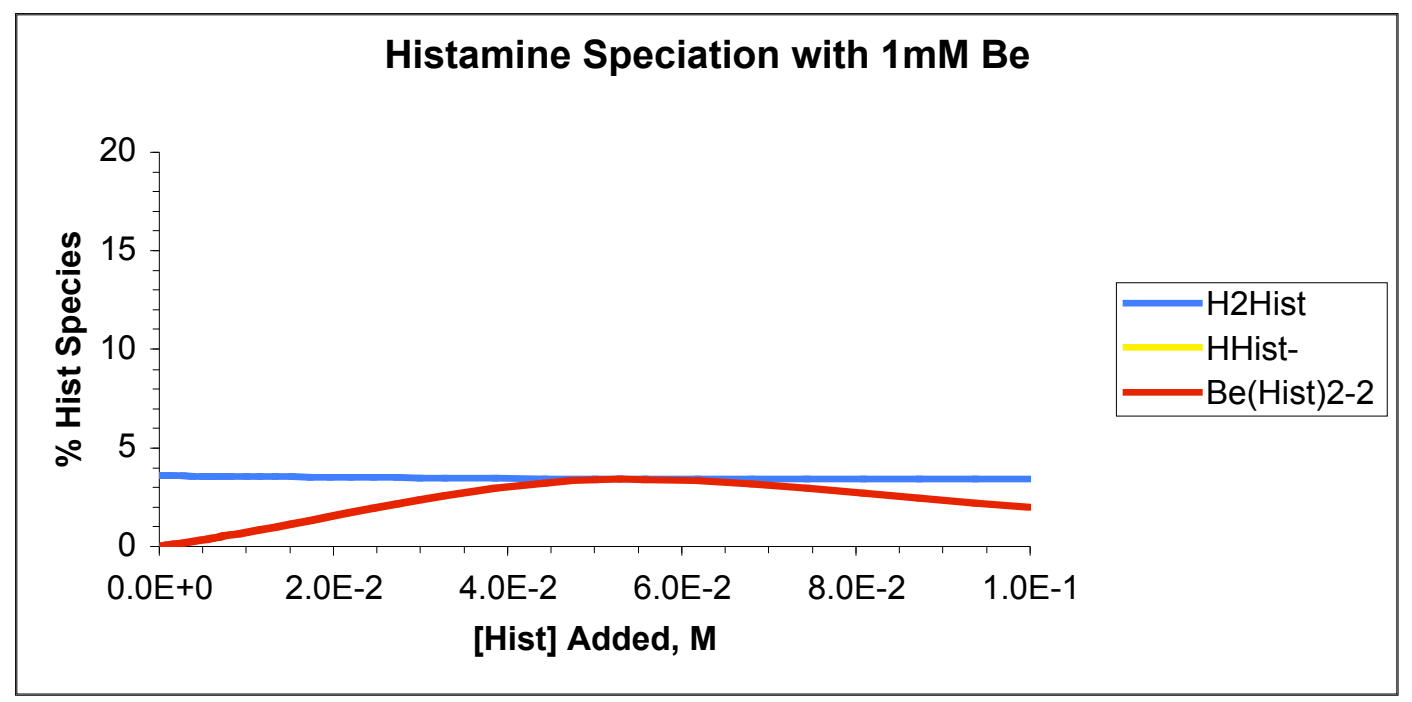

Figure 3-14. Catechol speciation in interstitial fluid with added beryllium 


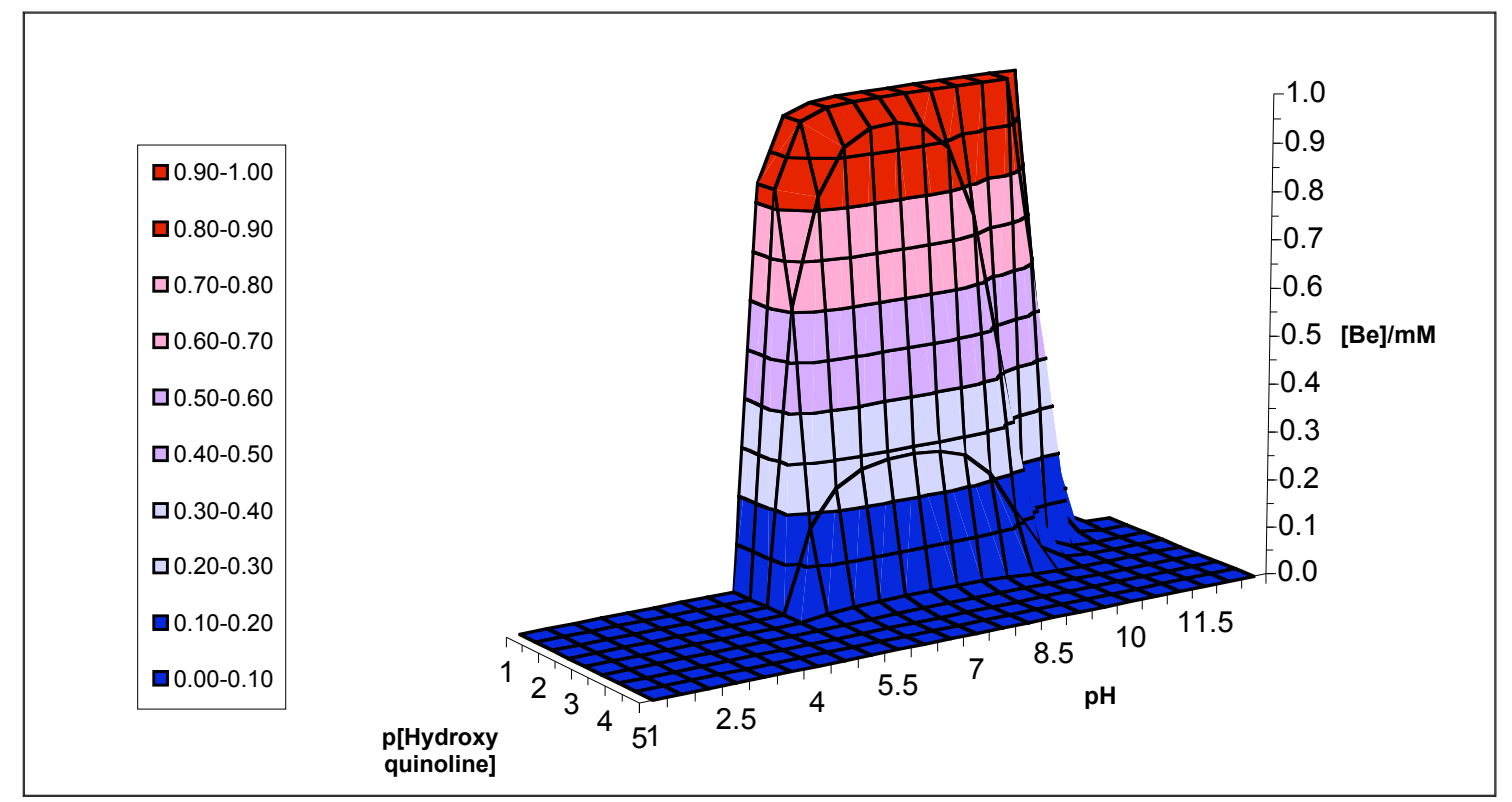

Figure 3-15. Effect of Hydroxyquinoline and pH on beryllium solubility in simulated interstitial fluid.

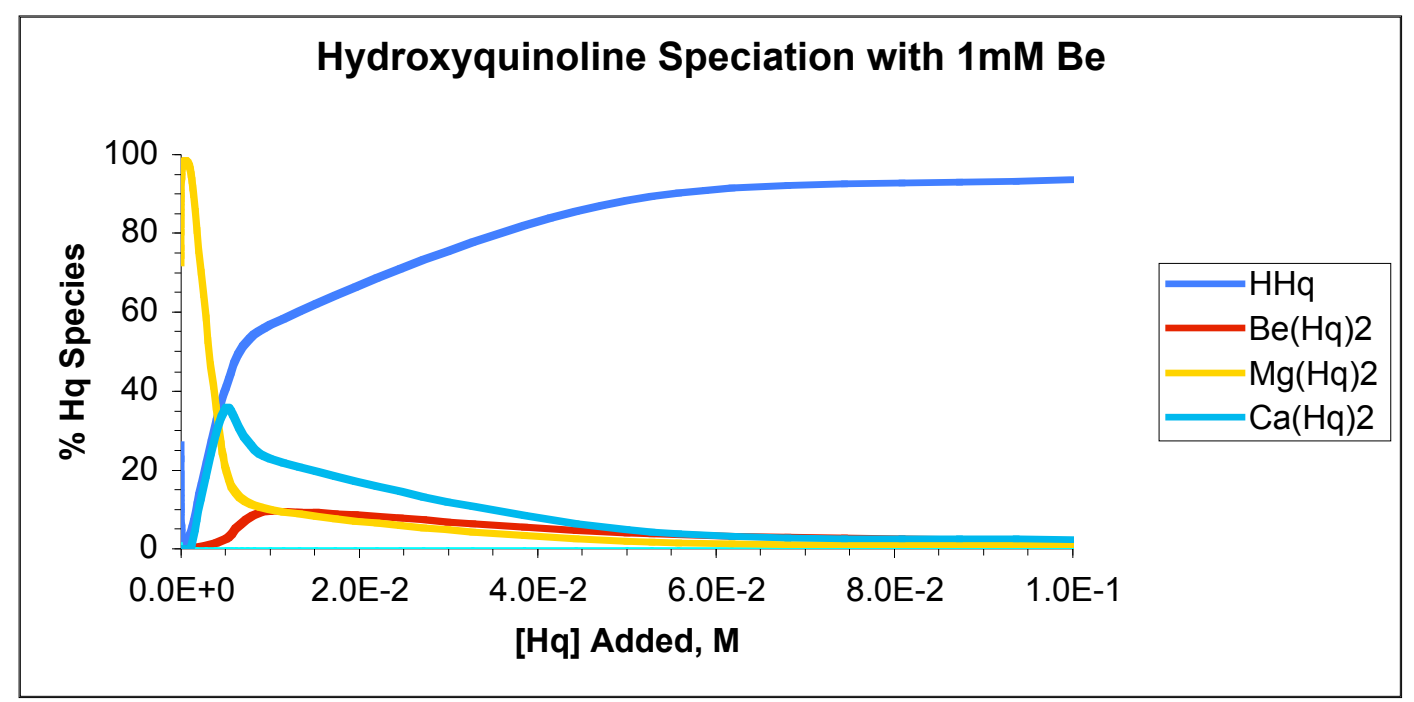

Figure 3-16. Hydroxyquinoline speciation in interstitial fluid with added beryllium 


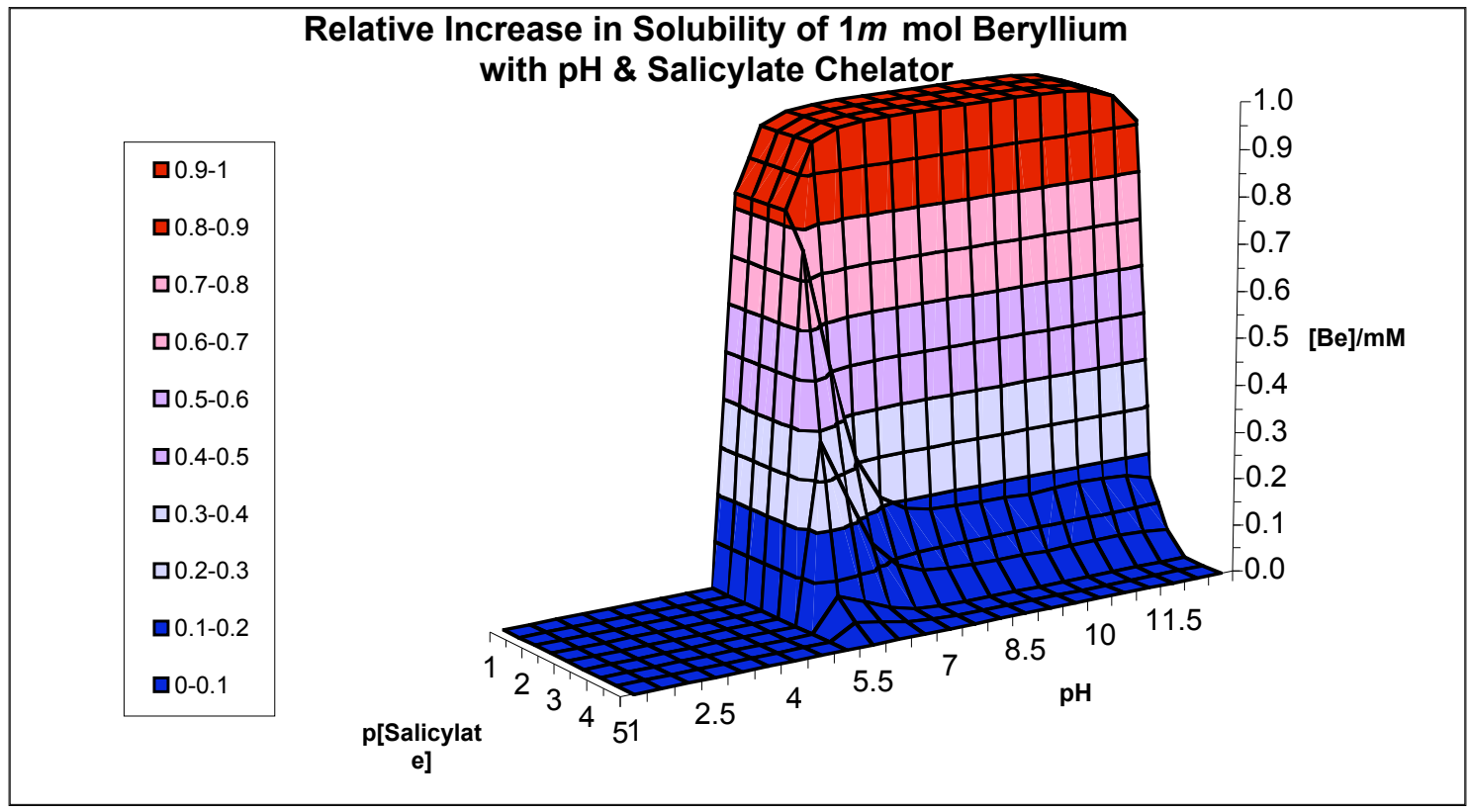

Figure 3-17. Effect of Salicylate and pH on beryllium solubility in simulated interstitial fluid.

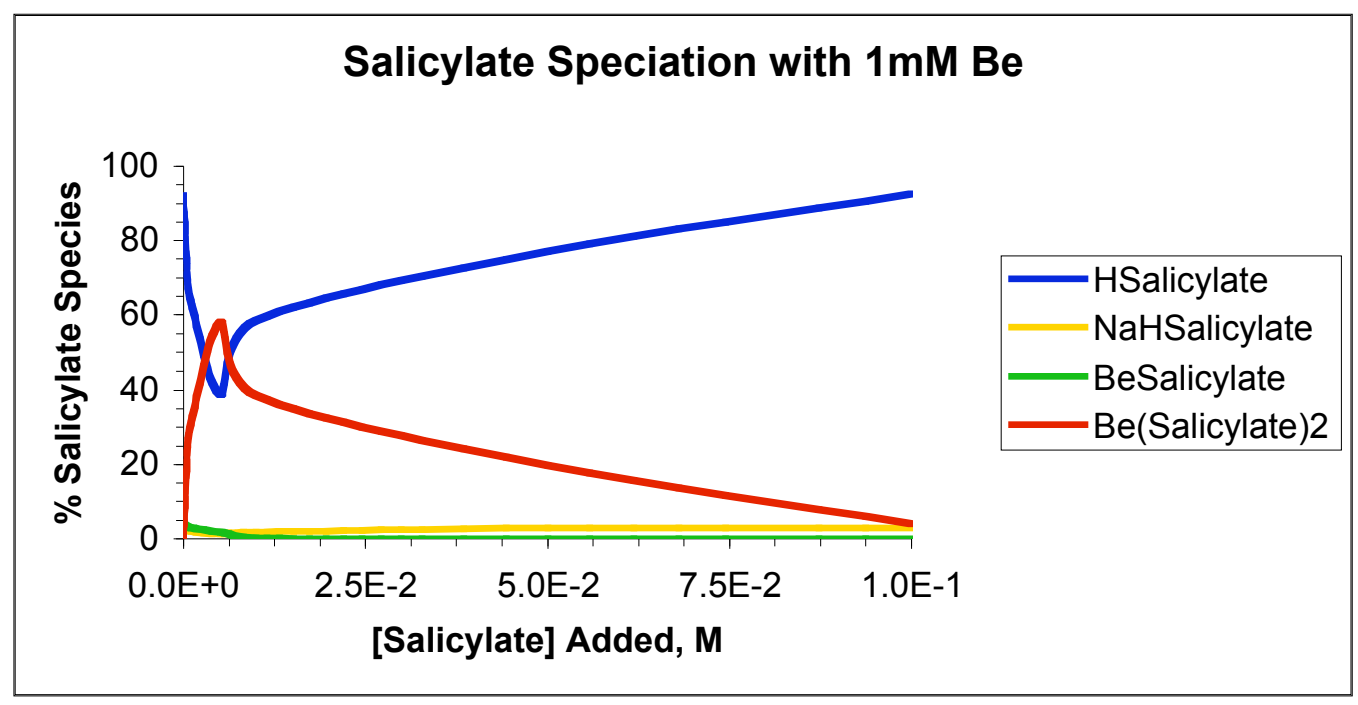

Figure 3-18. Salicylate speciation in interstitial fluid with added beryllium 
$\square 0.9-1$

$\square 0.8-0.9$

$\square 0.7-0.8$

$\square 0.6-0.7$

$\square 0.5-0.6$

$\square 0.4-0.5$

$\square 0.3-0.4$

$\square 0.2-0.3$

$\square 0.1-0.2$

$\square 0-0.1$

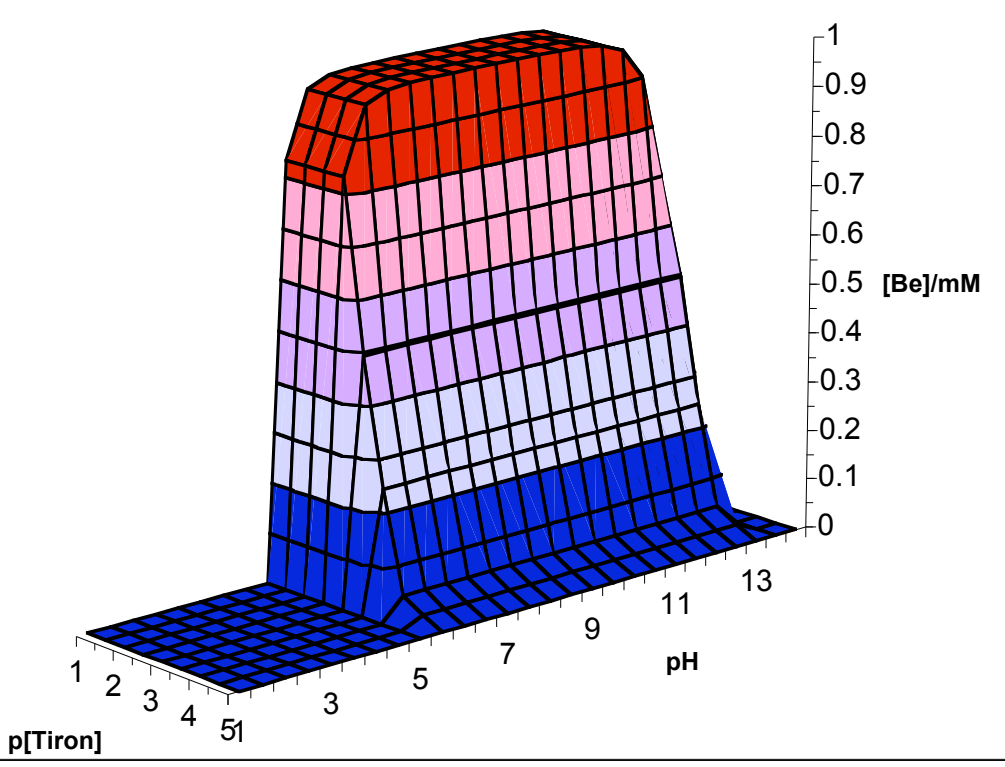

Figure 3-19. Effect of Tiron and $\mathrm{pH}$ on beryllium solubility in simulated interstitial fluid.

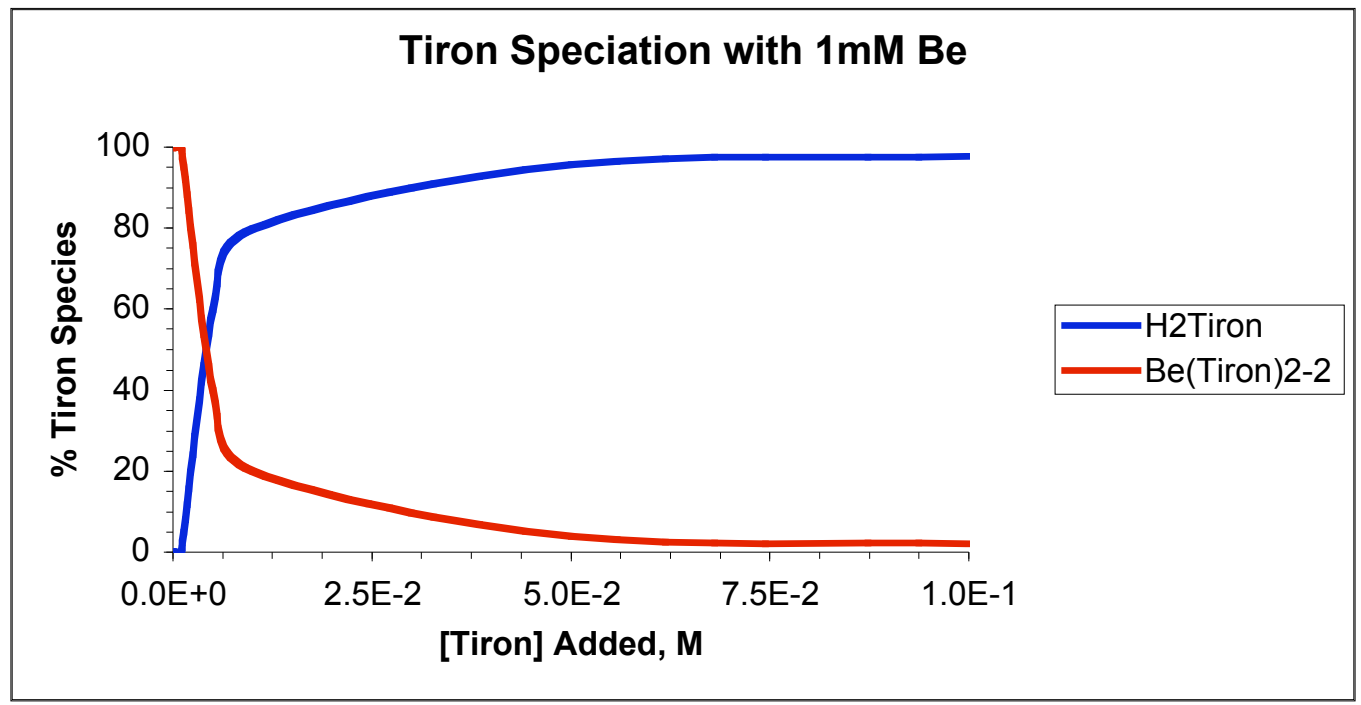

Figure 3-20. Tiron speciation in interstitial fluid with added beryllium 


\subsubsection{Structure and Functional Group Variation.}

After studying the speciation and solubility of beryllium with the above mentioned chelators, it was clear that three groups of chelators stood out as being potential candidates for experimental investigation - APMDP, DNSA and tiron. However, within those groups, there are adjustments that can be made to the chain-length, functional groups and structure isomerism that can yield information on the best possible conformation for effective and selective beryllium binding.

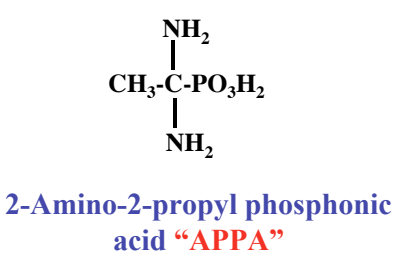
acid "APPA"
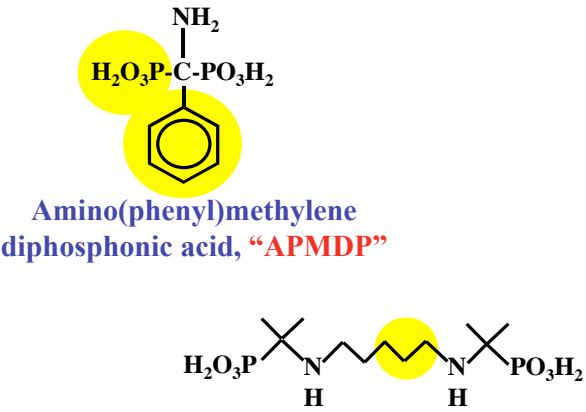

Pentamethylene[imino(dimethyl) methylene diphosphonic acid] "PMDIP"

Ethylenebis[imino(dimethyl)methylene diphosphonic acid] "EDDPO"

Thiobis[ethyleneimino(dimethyl)methylene diphosphonic acid] "TEDIP"

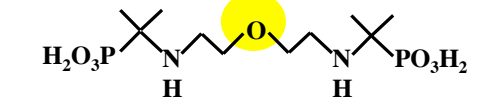

Oxybis[ethyleneimino(dimethyl)methylene diphosphonic acid] "OEDIP"

Figure 3-21. Diphosphonic acid structure and functional group variation. Important structural changes highlighted in yellow. 


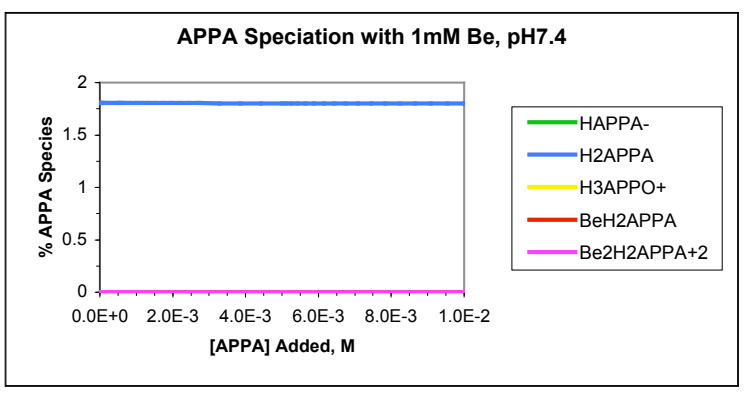

Relative Increase in Solubility of $1 \mathrm{mmol}$ Beryllium with $\mathrm{pH}$ \& APPA Chelator

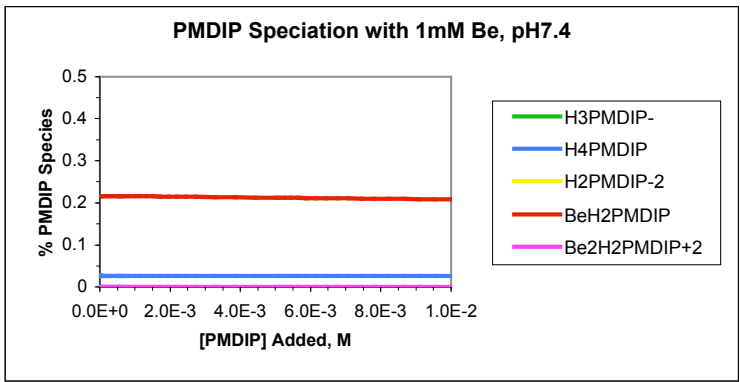

Relative Increase in Solubility of $1 \mathrm{mmol}$ Beryllium with $\mathrm{pH}$ \& PMDIP Chelator

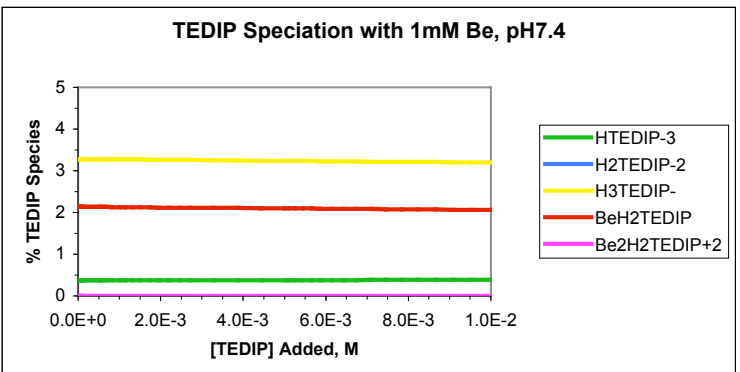

Relative Increase in Solubility of $1 \mathrm{mmol}$ Beryllium with $\mathrm{pH}$
\& TEDIP Chelator

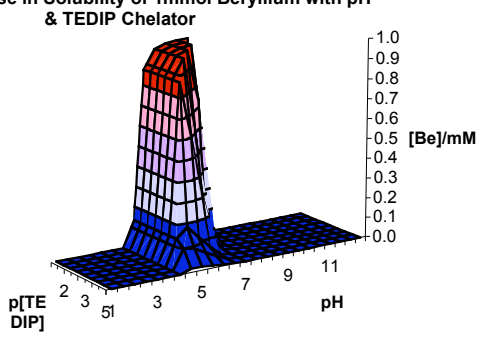

Figure 3-22a. Effect of diphosphonic acid structure and functional group variation on chelator speciation and beryllium solubility. 

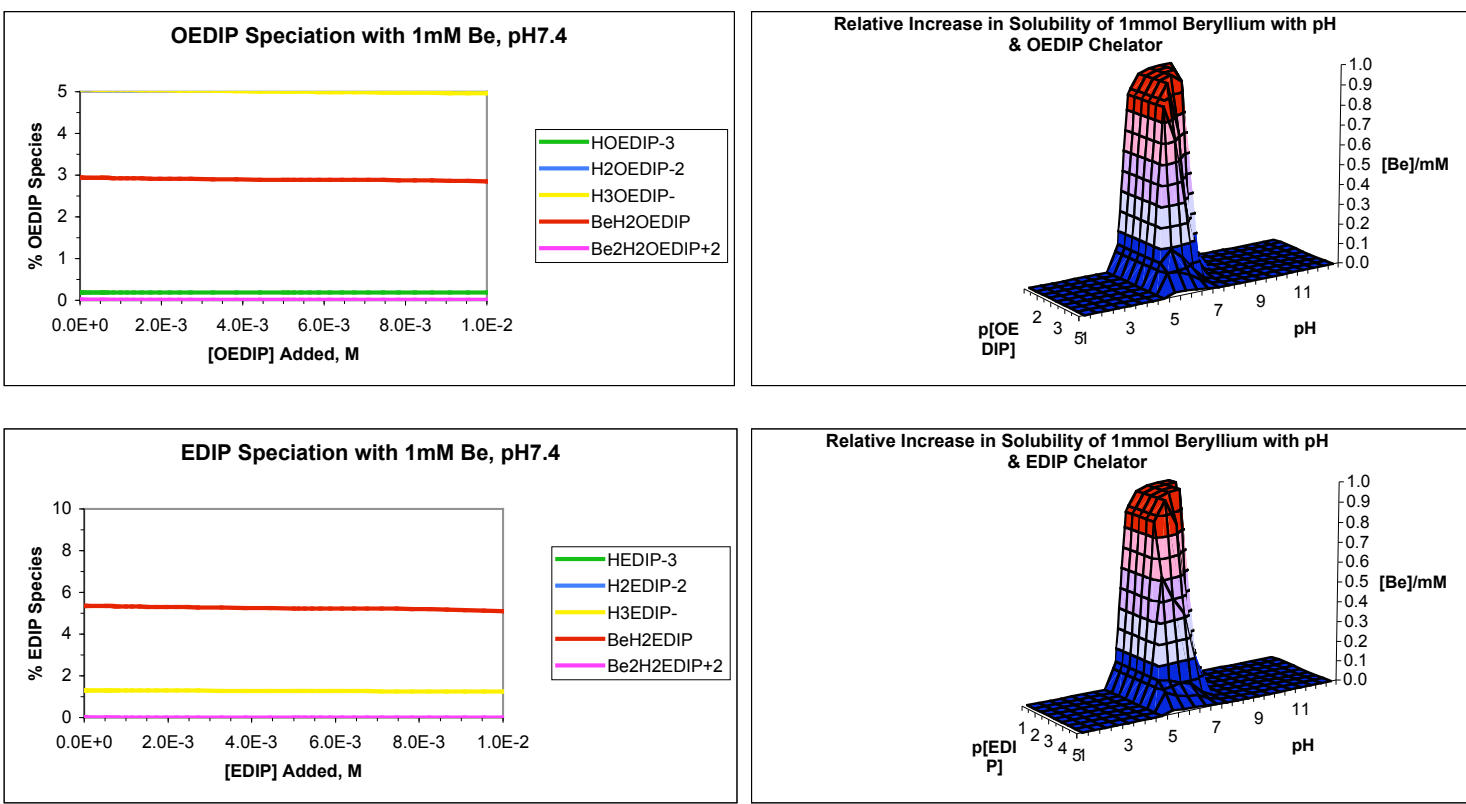

Relative Increase in Solubility of $1 \mathrm{mmol}$ Beryllium with $\mathrm{pH}$
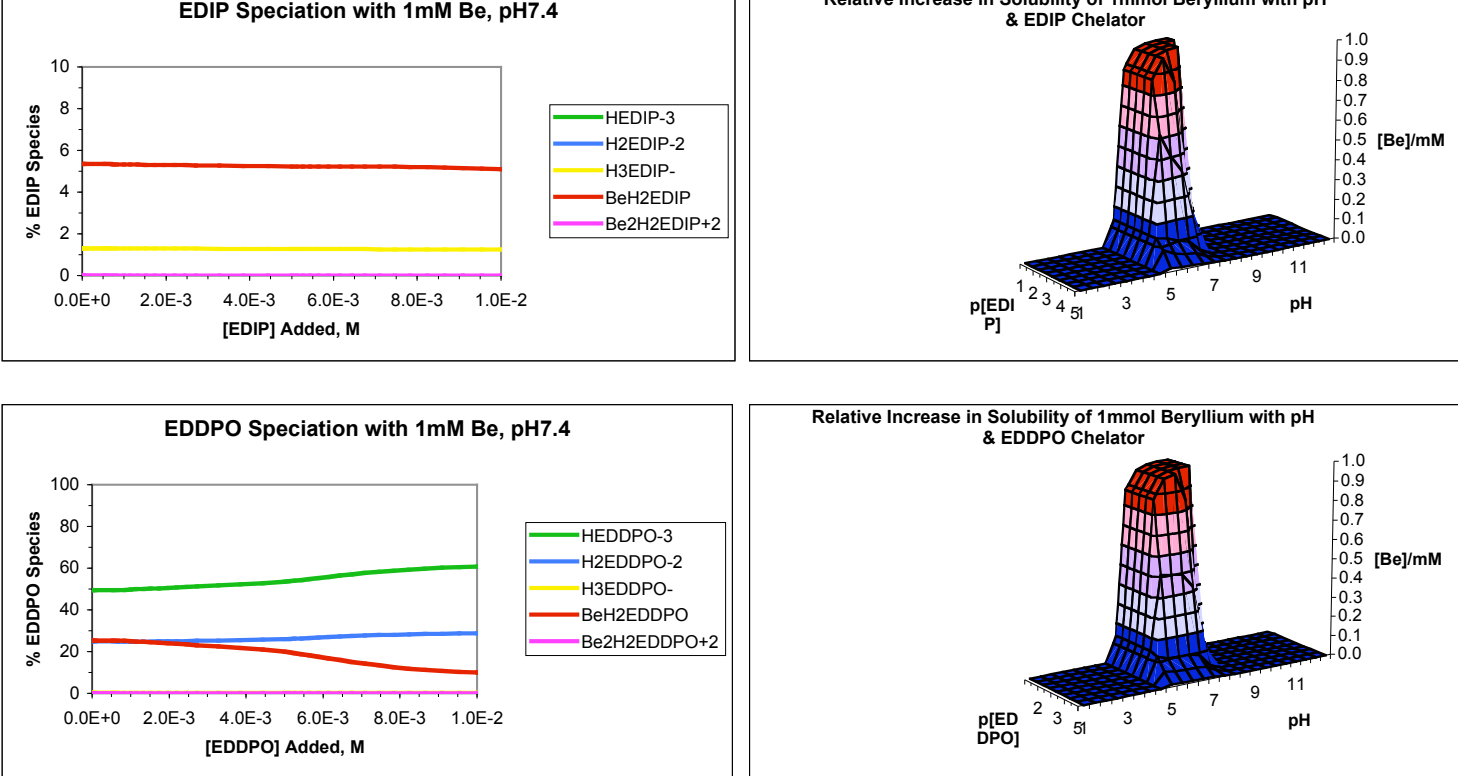

Relative Increase in Solubility of $1 \mathrm{mmol}$ Beryllium with $\mathrm{pH}$ \& EDDPO Chelator
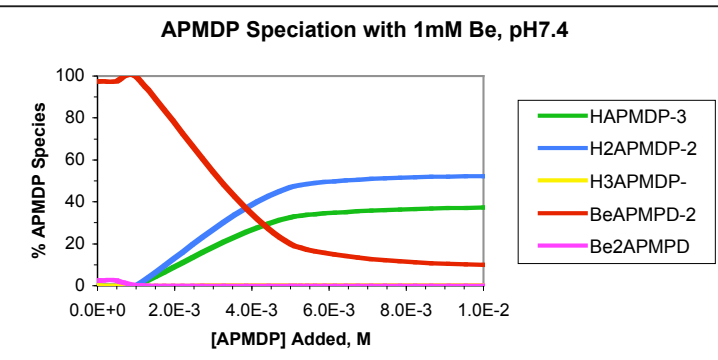

Relative Increase in Solubility of $1 \mathrm{mmol}$ Beryllium with $\mathrm{pH}$ \& APMDP Chelator

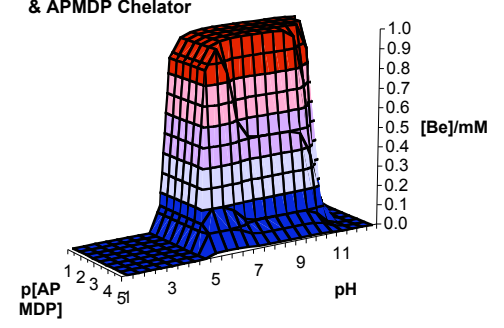

Figure 3-22b. Effect of diphosphonic acid structure and functional group variation on chelator speciation and beryllium solubility. 


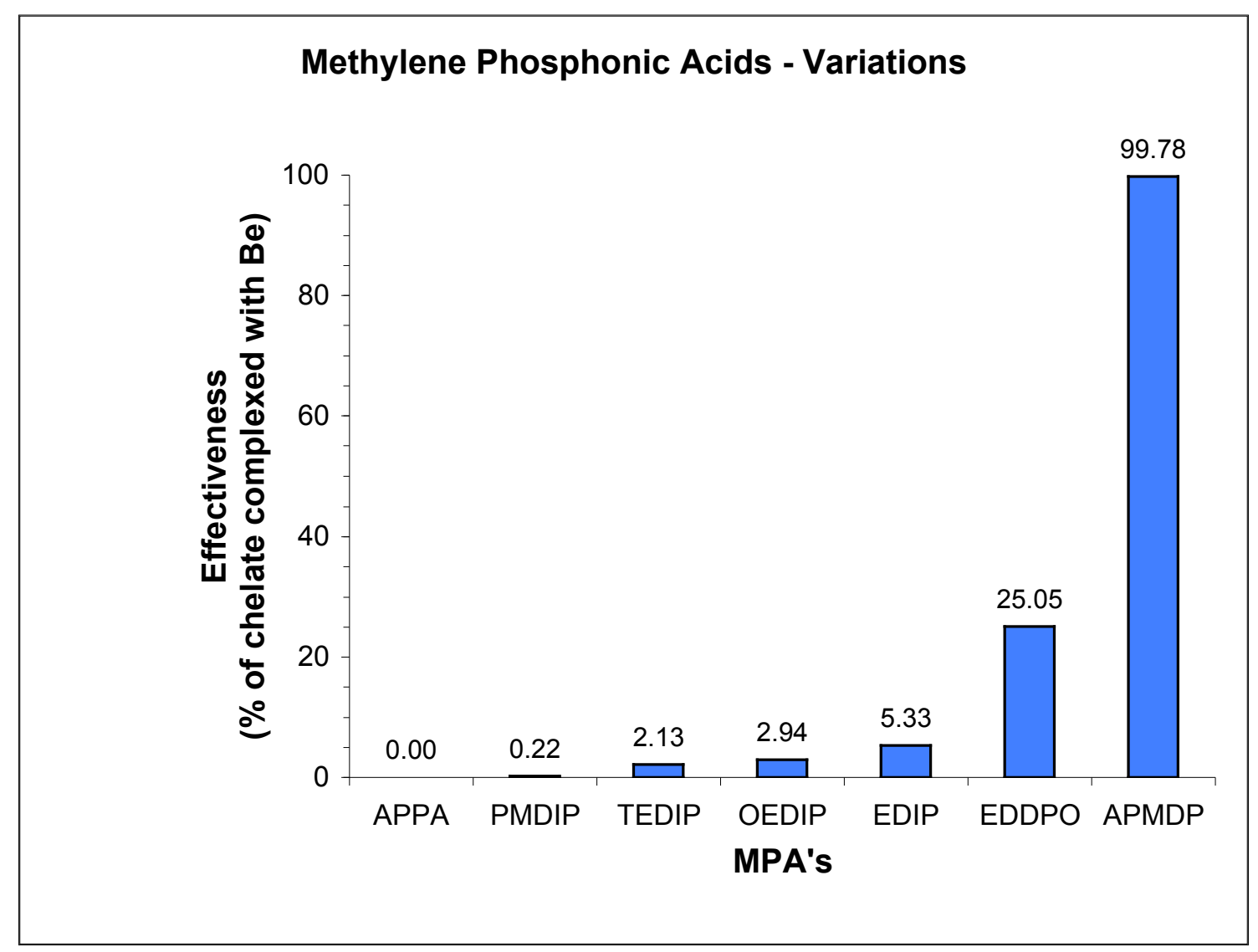

Figure 3-23. Effectiveness of methylene phosphonic acids in chelating beryllium.

Figure 3-23 shows that APMDP is clearly the most effective methylene phosphonic acid in our study. 

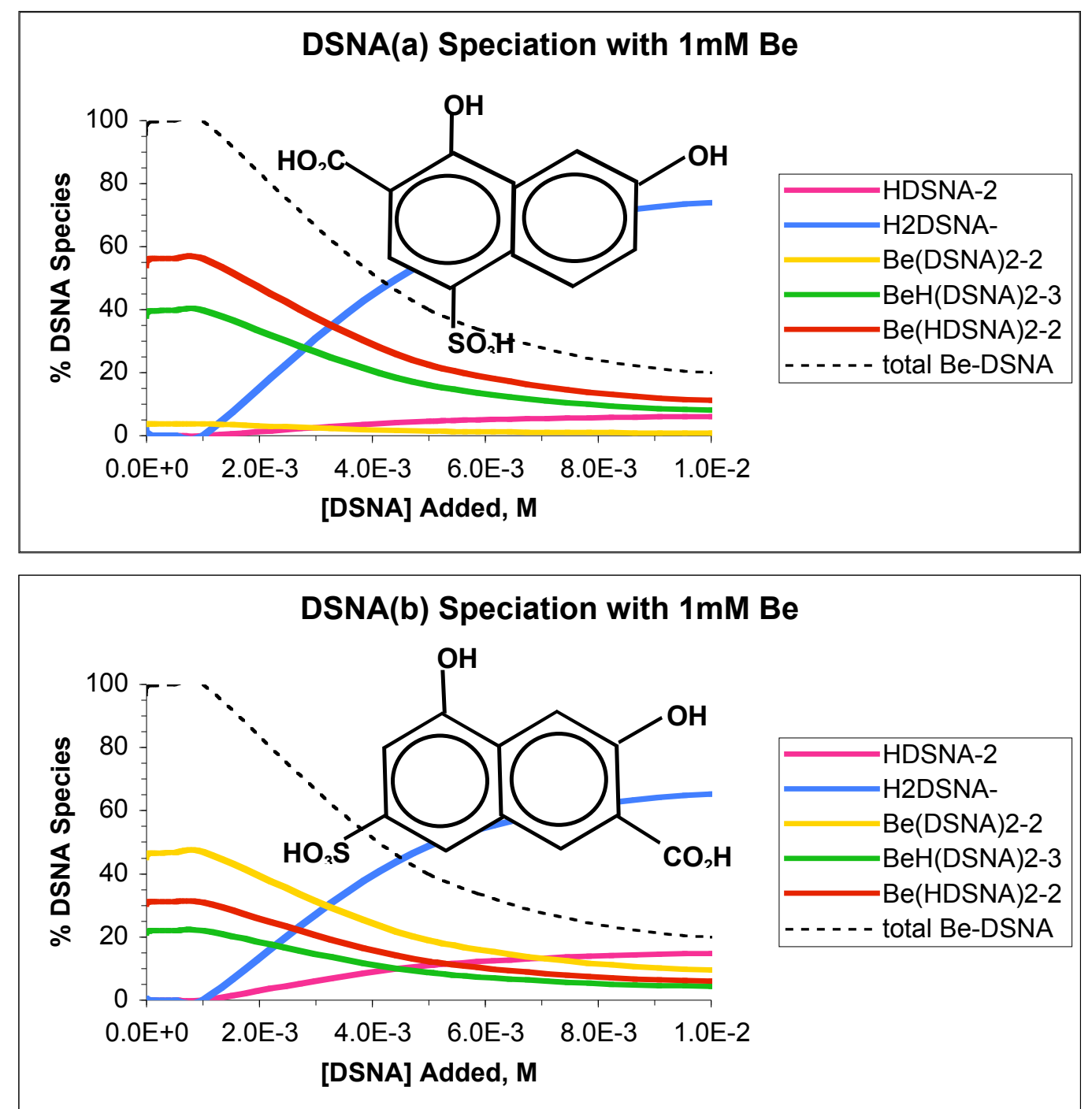

Figure 3-24. DSNA speciation in beryllium solutions with various isomers of DSNA

Figure 3-24 above shows that while DSNA is a good chelator for beryllium, the speciation varies with the DSNA isomer 


\subsection{Toxicology}

Some are know and toxicology data on others have not been reported fully. In the "Registry of Toxic Effects of Chemical Substances" (published by NIOSH) we found data of similar compounds to help formulate trends that may help asses the toxicity of the questioned compounds. Generally, the more water soluble a compound, the more easily it is excreted, thus reducing it toxicity. Less water soluble compounds that are more lipid in composition tend to enter target tissues to convey some degree of adverse effects. Trents can be seen with the LD-50 data and more polar compounds are often less toxic. Problems can arise during the metabolism of functionalized aromatic compounds. If quinone metabolites are possible, toxicity can go up. Hydroxyl- and nitroso-compounds can be metabolic products of nitro-aromatics. These metabolites can then transform into quinines to convey enhanced toxicity. Blocking the metabolic pathway leading to the formation of quinones tends to greatly reduce the generation of toxic metabolites. Carboxylic acids, sulfates, and phosphonates are very water soluble and compounds with these functionalities are generally less toxic than amines and sulfhydro-compounds. In Table 3-1, we have organized LD-50 (oral-rat) data of compounds similar to the compounds in question. To obtain a "ball-park" range of toxicities for the unknown chemicals one can bracket them with know LD-50 levels of similar compounds. Some of the findings and extrapolated toxicology levels are highlighted below.

(a) Catechol (pyrocatechol) - Published data indicated minimum LD-50 levels for the rat as $300 \mathrm{mg} / \mathrm{Kg}$. This is a little more toxic than phenol $(414 \mathrm{mg} / \mathrm{Kg})$, but in the range of similar phenol compounds.

(b) Pyrogallol - When compared to catechol, this compounds possesses an additional hydroxyl group (when compared to catechol), has increased polarity, and diminished potential to form quinones. The minimum LD-50 in rat is $1,000 \mathrm{mg} / \mathrm{Kg}$.

(c) Gentistic Acid - Although more polar this compound is a metabolite of salicylic acid (p-hydroxysalicylate). Salicylic acid derivatives interfere with prostaglandin biosynthesis and at high doses convey a level of toxicity (LD-50 $800 \mathrm{mg} / \mathrm{Kg}$ ) higher than benzoic acid or its p-hydroxymetabolite (LD-50 3,040 and 3,200 mg/Kg, respectively).

(d) Tiron (1,2-dihydroxybenzene-3,5-disulonic acid) - This compound has no reported LD-50 data in the "Registry of Toxic Effects of Chemical Substances". However, this compound is highly polar, is functionalized with two sulfonic groups and two orthohydroxy groups, it very water soluble and should be easily excreted. In order to extrapolate its toxicity, the LD-50 of similar sulfate compounds is known. Benzenesulfonic acid (LD-50 is $890 \mathrm{mg} / \mathrm{Kg}$ ) is a strong acid and possibly toxic because it could acid-burn tissues. In contrast the sodium salt of benzenesulfonic acid (a weak base) possesses an LD-50 of $3,200 \mathrm{mg} / \mathrm{Kg}$. Functionalize benzenesulfonic acids that have increased polarity and are water soluble (e.g. 2-methyl-5 nitrobenzenesulfonic acid, LD$503,710 \mathrm{mg} / \mathrm{Kg}$ ) possess less toxicity. Therefore, the LD-50 of Tiron may be in the range of $3,000-4000, \mathrm{mg} / \mathrm{Kg}$. 
(e) 3,5-Dinitrocatechol - This compound has no reported LD-50 data in the "Registry of Toxic Effects of Chemical Substances". It possesses a number of metabolic possibilities that may result in metabolites with more toxicity than the parent compound. Nitroaromatic compounds are metabolized to quinones and nitroso-aromatic compounds, all of which posses a reasonable degree of toxicity (e.g., p-nitrophenol, LD-50 350 $\mathrm{mg} / \mathrm{Kg}$ ). However, when metabolically stable para-quinones are not easily formed (e.g., o-nitrophenol, LD-50 2,828 mg/Kg) less toxicity is observed. Nitro- and hydroxylsubstiruted analogs of nitrophenols appear to possess increased toxicity (see table of LD50s $15 \mathrm{mg}$-190 mg/Kg,). Therefore, 3,5-dinitrocatechol should at least be classified with a toxicity in the range of $15 \mathrm{mg}-100 \mathrm{mg} / \mathrm{Kg}$.

(f) $\alpha, \alpha$-Diphosphonvlbenzylamine - This compound has no reported LD-50 data in the "Registry of Toxic Effects of Chemical Substances". It possesses a high degree of polarity. Benzylamine is reasonable toxic (LD-50 of $128 \mathrm{mg} / \mathrm{Kg}$ ) possibly due to metabolic interference with catecholamine biosynthesis. Substitution of alkyl groups near the amine appear to reduce the toxicity of the benzyl-amine (e.g., a-methylbenzylamine LD-50 $940 \mathrm{mg} / \mathrm{Kg}$ ). Substitution of alkyl groups on the amine increase the toxicity of benzylamines by reducing water solubility and increasing membrane permeability (e.g., $\mathrm{N}$,N-dimethyl-a-methylbenzylamine, LD-50 $420 \mathrm{mg} / \mathrm{Kg}$ ). In contrast, phenylphosphonic acid is water soluble, yet toxic at $110 \mathrm{mg} / \mathrm{Kg}$ possibly due to its stronger acid properties. Therefore, with this toxicology data, the questioned molecule (a,adiphosphonylbenzylamine) which possesses both functionalities (ct-substituted benzylamine and two phosphonic acids) in the same molecule, may exhibit an LD-50 in the range of $400 \mathrm{mg}-900 \mathrm{mg} / \mathrm{Kg}$.

(g) EDAPO - This compound has no reported LD-50 data in the "Registry of Toxic Effects of Chemical Substances". It is a highly polar compound and similar compounds possess an LD-50 values in the range of $500-2,000 \mathrm{mg} / \mathrm{Kg}$ (see table). The trend is that as more polar compounds are added to the basic 1,2-diaminoethane compound, the toxicity goes down. Therefore, EDAPO possibly possesses an LD-50 level in the range of 2,000$3,000 \mathrm{mg} / \mathrm{Kg}$.

(h) EDIP - This compound also has no reported LD-50 data in the "Registry of Toxic Effects of Chemical Substances". It is also a highly polar compound and similar compounds (see table) possess an LD-50 values in the range of 500-2,000 $\mathrm{mg} / \mathrm{Kg}$. The terminal carbon atoms on opposite ends of the molecule are blocked with two methyl groups making the compound more lipid in nature. More lipid phosphonic materials are possibly more toxic because they can cross cellular membranes more easily. Therefore, EDAPO may possess LD-50 levels of 1,000-2,000 mg/Kg and be slightly more toxic than EDAPO.

(i) Dimethyl-amino-methanephosphonic acid - This is a compact, highly polar compound. This compound has no reported LD-50 data in the "Registry of Toxic Effects of Chemical Substances". Similar compounds possess an LD-50 values in the range of 820mg to 3,723 $\mathrm{mg} / \mathrm{Kg}$ (see table). The acid nature of the phosphonic acid may be additionally buffered by the alkyl amine, thus further reducing its direct acid toxicity. Alkylphosphonates are 
reasonable non-toxic and therefore when compared to similar analogs this compound may possess an $\mathrm{LD}-50$ value $>2,000 \mathrm{mg} / \mathrm{Kg}$.

(j) 1 J-Dihydroxy-4-sulfonate-2-naphthoic acid - This highly polar compound was not listed in the "Registry of Toxic Effects of Chemical Substances". However, other similar substituted naphthoic acid compounds were listed. Typically naphthols (LD-50 2,4202,590 mg/Kg) and substituted carboxylic acid naphthalene compounds (LD-50 500-2,370 $\mathrm{mg} / \mathrm{Kg}$ ) possess reasonably low toxicities. However, when salicylic acid analogs of naphthalene are considered toxicity can dramatically increase (e.g., 2-hydroxynaphthoic acid, LD-50 $12 \mathrm{mg} / \mathrm{Kg}$ ). Sulfonic acid substituted groups on naphthalene rings greatly increase their water solubility. Therefore, is can be proposed that 1,7-dihyroxy-4sulfonate-2-naphtoic acid would be very water soluble, dissimilar to salicylic acid (incorrect geometric orientation), and potentially have and LD-50 >500 mg/Kg and possibly as high as $3,000 \mathrm{mg} / \mathrm{Kg}$.

(k) 3,5-Dihydroxv-7-sulfonate-2-naphthoic acid - This compound is also highly polar, is not a salicylic acid analog, and does not have the ability to be easily metabolized to naphthaquinone compounds. Therefore, similarly to other hydroxyl-, sulfonic-, and carboxylic acid substituted naphthalene compounds, 3,5-dihydroxy-7-sulfonate-2naphthoica acid may possess a LD-50 value in the range of $500 \mathrm{mg}$ to $3,000 \mathrm{mg} / \mathrm{Kg}$.

In conclusion, the majority of compounds appear to be reasonably non-toxic. One compound, 3,5-dinitrocatechol may possess an LD-50 in rat and human that would be of concern based on known data of similar nitrophenols. Many of the other compounds are quite polar (water soluble) and possibly would be excreted quickly contributing to a very low level of toxicity. These latter compounds also possess functional groups that should not impact specific metabolic processes (e.g., acetylcholine enzymes, GABA, catecholamines, other neurotransmitters, Crebs cycle, blood chemistry, typical enzyme pathways, etc.).

\begin{tabular}{|l|l|c|}
\hline Compound & Formula & $\begin{array}{l}\text { Lowest Lethal } \\
\text { Dose (LD-50 } \\
\text { oral-rat, mg/Kg) }\end{array}$ \\
\hline Phenol & & 414 \\
\hline Catechol (pyrocatechol) & & 300 \\
\hline Resorcinol & & 301 \\
\hline Hydroquinone (1,4-dihydroxybenzene) & & 320 \\
\hline p-Benzoquinone & & 130 \\
\hline Pyrogallol & & 1,000 \\
\hline Benzoic Acid & & 3,040 \\
\hline p-Hydrobenzoate & & 3,200 \\
\hline Gentistic Acid & & 800 \\
\hline Benzenesulfonic Acid & & 890 \\
\hline Benzenesulfonic Acid Sodium salt & & 3,200 \\
\hline 2-Methyl-5-nitrobenzene sulfonate & 3,710 \\
\hline Tiron & & $3,000-4,000^{\mathrm{a}}$ \\
\hline
\end{tabular}




\begin{tabular}{|l|l|c|}
\hline Compound & Formula & $\begin{array}{l}\text { Lowest Lethal } \\
\text { Dose (LD-50 } \\
\text { oral-rat, mg/Kg) }\end{array}$ \\
\hline p-Nitrophenol & & 350 \\
\hline m-Nitrophenol & & 447 \\
\hline o-Nitrophenol & & 2,828 \\
\hline 2,5-Dinitrophenol & & 15 \\
\hline 2,4-Dinitrophenol & & 30 \\
\hline 2,6-Dinitrophenol & & 40 \\
\hline 3,5-Dinitrophenol & & 45 \\
\hline 3,4-Dinitrophenol & & 98 \\
\hline 2,3-Dinitrophenol & & 190 \\
\hline 3,5-Dinitrocatechol & & $15-100^{\mathrm{a}}$ \\
\hline Benzylamine & & 128 \\
\hline a-Methylbenzylamine & 940 \\
\hline N,N-Dimethyl-a-methylbenzylamine & 420 \\
\hline Phenylphosphonic Acid & & 110 \\
\hline Phenylphosphonyldiamide & & 625 \\
\hline a,a-Diphosphonylbenzylamine (APMDP) & & $400-900^{\mathrm{a}}$ \\
\hline 1,2-Diaminoethane & & 500 \\
\hline Diethylenetriamine & & 1,080 \\
\hline N,N-isopropyl-1,2-ethanediame & 200 \\
\hline N,N-diphenyl-1,2-ethanediame & & 500 \\
\hline N,N-tetramethyl-1,2-ethyldiame & & 1,500 \\
\hline 1,2-ethyldiamine-N,N-tetraacetic acid & & 2000 \\
\hline 1,2-Ethanediamine-N,N-Dimethylene-phosphonate & & $2,000-3,000^{\mathrm{a}}$ \\
(EDAPO) & & \\
\hline EDIP & & $1,000-2,000^{\mathrm{a}}$ \\
\hline Propylamine & & 570 \\
\hline Propylformate & & 3,980 \\
\hline Butyric acid & & 2,940 \\
\hline Propylphosphonic acid & & 3,723 \\
\hline Ethylamine & & 400 \\
\hline Isopropylamine & & 820 \\
\hline Dimethyl-amino-methanephosphonic acid & $2,000^{\mathrm{a}}$ \\
\hline 2-Naphthol & & 2,420 \\
\hline 1-Naphthol & & 5000 \\
\hline 2-Naphthoic acid & & \\
\hline 1-Naphthoic acid & & 125 \\
\hline 2-Hydroxy-1-naphthoic acid & & \\
\hline 2-Hydroxybenzoic acid (salicylic acid) & & \\
\hline 2-Naphthalenesulfate & & \\
\hline 6-Hydroxy-2-naphthalenesulfonic acid & & \\
\hline 2-Hydroxy-1-naphthalenesulfate & & \\
\hline 1,7-Dihydroxy-7-sulfonate-2-naphthoic acid & & \\
\hline & & \\
\hline
\end{tabular}




\begin{tabular}{|l|l|c|}
\hline Compound & Formula & $\begin{array}{l}\text { Lowest Lethal } \\
\text { Dose }(\mathbf{L D}-50 \\
\text { oral-rat, } \mathbf{~ m g} / \mathbf{K g})\end{array}$ \\
\hline 3,5-Dihydroxy-7-sulfonate-2-napthoic acid & & $500-3,000^{\mathrm{a}}$ \\
\hline
\end{tabular}

Table 3-1. Literature and estimated lowest lethal dose (LD-50). Highlighted compounds are those considered for chelation treatment. ${ }^{a}$ Estimated values based on chemical analogues.

Based on our knowledge so far, the best chelator to progress to laboratory and animal trials was APMDP. The toxicity comparison can be graphically demonstrated in Figure 325 .

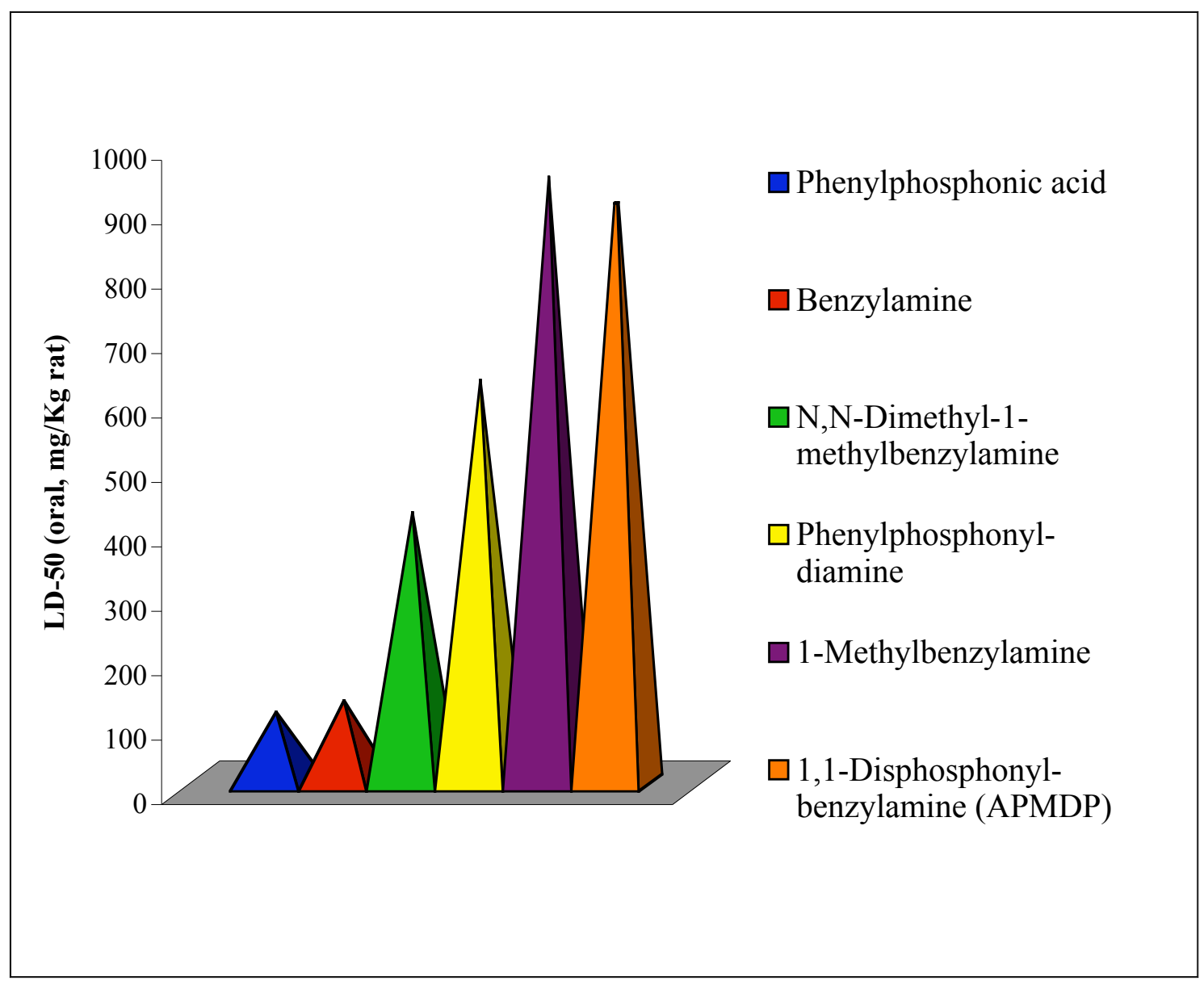

Figure 3-25. Toxicity estimate of APMDP based on known LD-50 data for phosphonic acid analogues. 


\subsection{Synthesis}

$\alpha$-Aminobenzyl- $\alpha, \alpha,-$ diphosphoric acid was synthesized according to a previously described procedure (Ref) and is outlined in Figure 3-26.

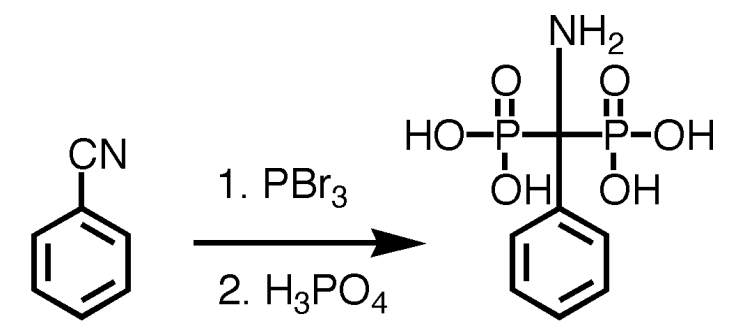

Figure 3-26. Schematic of APMDP synthesis.

Patent: Lerch, I.; Kottler, A. Experiments in the production of $\alpha$-primary amino phosphoric acids and their esters; DE 1002355; 1954.

$\alpha$-Aminobenzyl- $\alpha, \alpha,-$ diphosphoric acid: $10 \mathrm{~g}$ of benzonitrile (Aldrich) was added dropwise at $0{ }^{\circ} \mathrm{C}$ to $54 \mathrm{~g}$ phosphoroustribromide (Aldrich) under an argon atmosphere. Upon complete addition, the mixture was stirred for $30 \mathrm{~min}$ before the dropwise addition of $35.4 \mathrm{~g}$ phosphoric acid (Aldrich) at $0{ }^{\circ} \mathrm{C}$. The mixture was warmed to RT and stirred for a further $3 \mathrm{~h}$ before being heated to $70{ }^{\circ} \mathrm{C}$ for $3 \mathrm{~h}$. Ice/water was added carefully to the gelatinous mixture with cooling and stirring. Charcoal was added to the resultant solution, which was then filtered through celite. The filtrate was reduced under vacuum to a yellow oil. The oil was divided into portions and the addition of acetone to the oil resulted in a colorless precipitate, which was collected by filtration. The resulting solid was recrystallized from water / acetone and dried under vacuum (10 g, $40 \%)$.

${ }^{1} \mathrm{H}$ NMR $\left(\mathrm{D}_{2} \mathrm{O}, 500 \mathrm{MHz}\right) \delta=7.10-7.25(\mathrm{~m}, 3 \mathrm{H}) ; 7.30-7.50(\mathrm{~m}, 2 \mathrm{H}):{ }^{13} \mathrm{C} \mathrm{NMR}\left(\mathrm{CDCl}_{3}\right.$, $125 \mathrm{MHz}) \delta=63.6\left(J_{\mathrm{CP}}=125 \mathrm{~Hz}\right), 127.3,129.3,130.0,134.7:{ }^{31} \mathrm{P}$ NMR $\left(\mathrm{CDCl}_{3}, 202\right.$ $\mathrm{MHz}) \delta=10.6$ : elemental analysis calculated (\%) for $\mathrm{C}_{7} \mathrm{H}_{15} \mathrm{NO}_{8} \mathrm{P}_{2} \cdot 2 \mathrm{H}_{2} \mathrm{O}$ (303.0) C 27.70, H 4.99, N 4.62, P 20.44: found C 27.97, H 5.04, N 5.42, P 20.05.

\subsection{Laboratory Experiments}

Laboratory experiments were performed to test the effectiveness of the chelator in dissolving and binding beryllium. The tests proved successful and beryllium solubility was increased with increasing concentrations of APMDP. These results were stored electronically and lost in a hard-drive failure in December 2003.

\section{$3.5{ }^{9} \mathrm{Be}$ NMR}

${ }^{9} \mathrm{Be}$ NMR spectra were obtained on a Bruker DRX 500 set at a spectral frequency of $70.2713 \mathrm{MHz}$, using a $5 \mathrm{~mm}$ TBI probe. The $90^{\circ}$ pulse length was set to $20.0 \mu \mathrm{s}$ with a recycle delay of $1 \mathrm{~s}$ and the number of scans was set to 2500 for a total acquisition time of one hour and seven minutes. ${ }^{9} \mathrm{Be}$ chemical shifts were referenced to $10 \mathrm{mM} \mathrm{BeSO}_{4}$ with downfield chemical shift values being reported as positive. All solutions contained $10 \% \mathrm{D}_{2} \mathrm{O}$ to provide a signal lock. 
The collective ${ }^{9} \mathrm{Be}$ NMR spectra for aqueous beryllium over the $\mathrm{pH}$ range 2.0 to 12.0 are shown in Figure 3-27 and support the results from thermodynamic modeling. At pH 2.0, 3.4 , and 4.2 the spectra show a single resonance at $0 \mathrm{ppm}$ which has been attributed to the free $\mathrm{Be}^{2+}$ ion in solution. The ${ }^{9} \mathrm{Be}$ spectrum for $\mathrm{pH} 5.0$ consists of a narrow peak at 0.14 ppm and a slightly broader beak at $0.60 \mathrm{ppm}$, which are assigned to the $\mathrm{Be}_{2} \mathrm{OH}^{3+}$ and $\mathrm{BeOH}^{+}$species, respectively. The broadening of the peak at $0.60 \mathrm{ppm}$ could be attributed either to an exchange between beryllium hydroxide species in solution or to quadrupolar coupling effects between the bonding beryllium and oxygen atoms. Consistent with thermodynamic modeling, the peak assigned to $\mathrm{Be}_{2} \mathrm{OH}^{3+}$ disappears from the ${ }^{9} \mathrm{Be}$ spectrum at $\mathrm{pH} 5.8$, leaving the single, broad resonance assigned to $\mathrm{BeOH}^{+}$. Though the experiments were repeated a number of times, beryllium sulfate solutions in the $\mathrm{pH}$ range 6.0-11.0 did not give rise to a ${ }^{9} \mathrm{Be}$ signal. The low solubility of beryllium hydroxide in water over that $\mathrm{pH}$ range caused the precipitation of beryllium sulfate solid which was filtered out of solution prior to NMR analyses, leaving an undetectable amount of beryllium in solution. The ${ }^{9} \mathrm{Be}$ signal returns at $\mathrm{pH} 12.0$ with a chemical shift value of 1.6 $\mathrm{ppm}$. This single resonance is slightly narrower than the resonance found at $\mathrm{pH} 5.0$ and 5.8 and has been assigned to the $\mathrm{Be}(\mathrm{OH})_{3}{ }^{-}$species. The narrowing of this peak is most likely a result of a decrease in the exchange between beryllium hydroxide species at such alkaline $\mathrm{pH}$. The downfield migration of the ${ }^{9} \mathrm{Be}$ chemical shift with increased $\mathrm{pH}$ supports the modeling of beryllium-hydroxide complexes begins at approximately $\mathrm{pH} 5.0$ and the broadening of ${ }^{9} \mathrm{Be}$ signals from $\mathrm{pH} 12.0$ to $\mathrm{pH} 5.0$ supports the larger number of beryllium hydroxide species present near more neutral $\mathrm{pH}$ values than at very alkaline $\mathrm{pH}$ values.

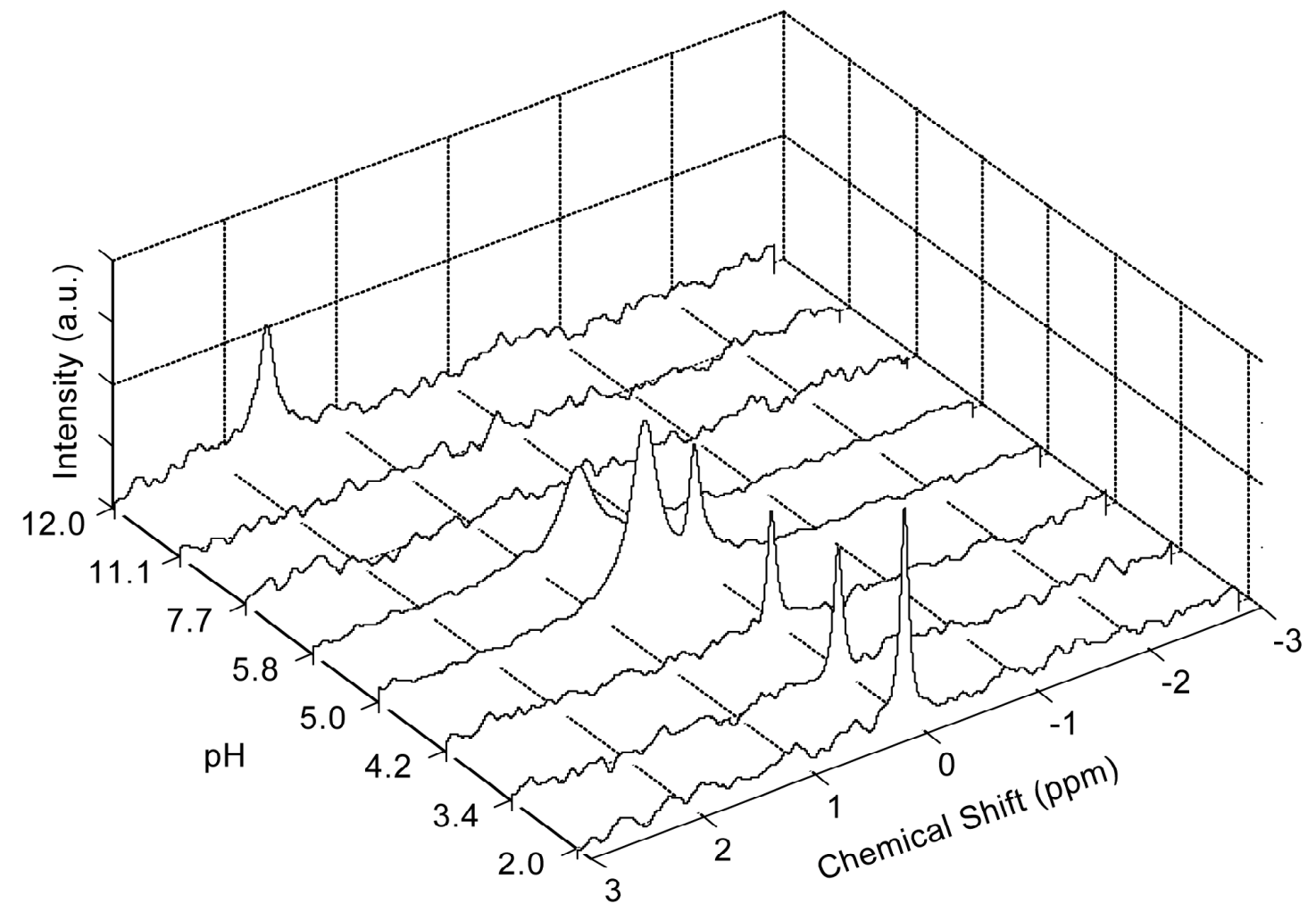

Figure 3-27. ${ }^{9} \mathrm{Be} \mathrm{NMR}$ spectra of $10 \mathrm{mM} \mathrm{BeSO}_{4}$ with $0.25 \mathrm{M} \mathrm{NaClO}_{4}$ over the $\mathrm{pH}$ range 2.0 - 12.0. 
The ${ }^{9} \mathrm{Be}$ NMR spectra for $10 \mathrm{mM}$ beryllium sulfate, $10 \mathrm{mM}$ beryllium sulfate with APMDP chelator and $10 \mathrm{mM}$ beryllium sulfate with Tiron chelator at $\mathrm{pH} 12$, are shown in Figure 3-28. The spectrum for beryllium sulfate (Figure 3-28a.) shows a single resonance at $1.6 \mathrm{ppm}$ assigned to $\mathrm{Be}(\mathrm{OH})_{3}{ }^{-}$. The spectrum for beryllium sulfate with APMDP chelator (Figure 3-28b.) shows a peak at $1.2 \mathrm{ppm}$ assigned to $\mathrm{Be}(\mathrm{OH})_{3}{ }^{-}$and a small peak at -0.41 assigned to the $[\mathrm{Be}(\mathrm{APMDP})]^{2-}$ species. The resonance for $\mathrm{Be}(\mathrm{OH})_{3}{ }^{-}$ is thought to be shifted upfield with respect to the $\mathrm{Be}(\mathrm{OH})_{3}{ }^{-}$resonance of the beryllium sulfate solution due to exchange between the $\mathrm{Be}(\mathrm{OH})_{3}{ }^{-}$species and the $[\mathrm{Be}(\mathrm{APMDP})]^{2-}$ species in solution. The spectrum with the Tiron chelator (Figure 3-28c.) shows two peaks representative of two possible binding mechanisms. The downfield chemical shift at $7.6 \mathrm{ppm}$ was assigned to the binding structure in which two Tiron molecules bind to a single beryllium ion through four beryllium-oxygen bonds. The peak with at $4.5 \mathrm{ppm}$ was assigned to the binding structure in which one Tiron molecule binds with a single beryllium ion through two beryllium-oxygen bonds. In the case where two Trion molecules are bound to one beryllium ion, the two extra oxygen atoms increase the electronegativity around the beryllium ion, causing the chemical shift to move downfield relative to the chemical shift for one Tiron molecule with one beryllium ion. It is interesting to note that the ${ }^{9} \mathrm{Be}$ chemical shift value is greatly influenced by the presence of either chelator. In the case of APMDP with beryllium sulfate the effect is an overall upfield chemical shift with respect to beryllium sulfate and in the case of Tiron with beryllium sulfate the effect is an overall downfield chemical shift with respect to beryllium sulfate. While both chelators bind to beryllium through oxygen atoms, each Tiron molecule has only two available binding oxygen atoms, both of which act to decrease the electron field around the beryllium ion. This effect is amplified when a second Tiron molecule is added and the overall Be-Tiron species becomes positively charged. The APMDP chelator, on the other hand, contains four possible binding oxygen

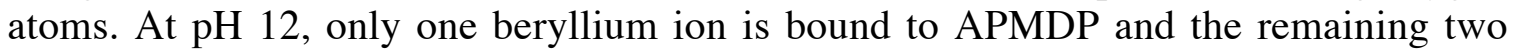
oxygen atoms acquire a negative charge. The increased electron density around the beryllium ion causes the chemical shift to move upfield with respect to both beryllium sulfate and beryllium sulfate with the Tiron chelator.

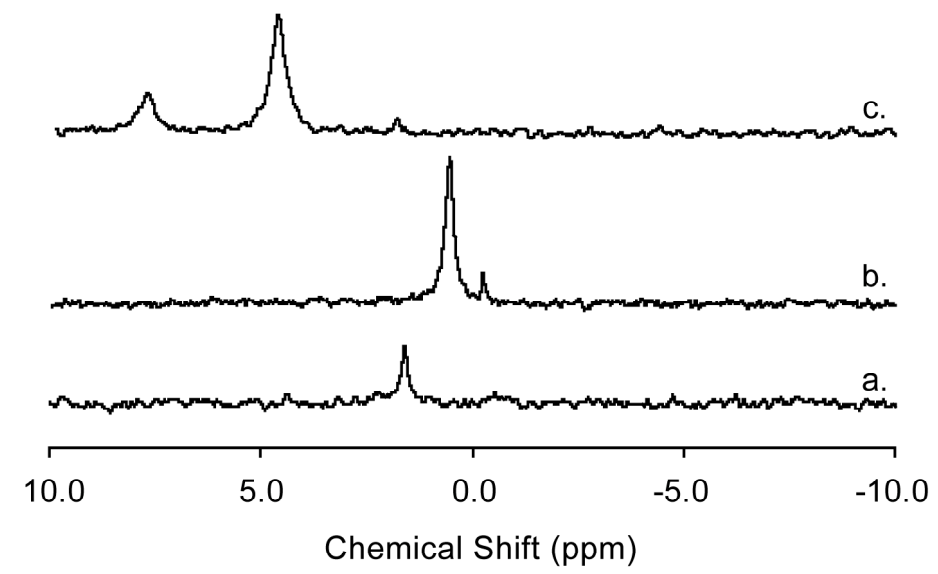

Figure 3-28. ${ }^{9}$ Be NMR spectra of beryllium sulfate and chelator solutions at pH 12. (a) $10 \mathrm{mM} \mathrm{BeSO}_{4}$ in $0.25 \mathrm{M} \mathrm{NaClO}_{4}$ with $\mathrm{NaOH}$, (b) $10 \mathrm{mM} \mathrm{BeSO}_{4}$ in $0.25 \mathrm{M} \mathrm{NaClO}$ with $\mathrm{NaOH}$ and APMDP chelator. (c) $10 \mathrm{mM} \mathrm{BeSO}_{4}$ in $0.25 \mathrm{M} \mathrm{NaClO}_{4}$ with $\mathrm{NaOH}$ and Tiron chelator. 


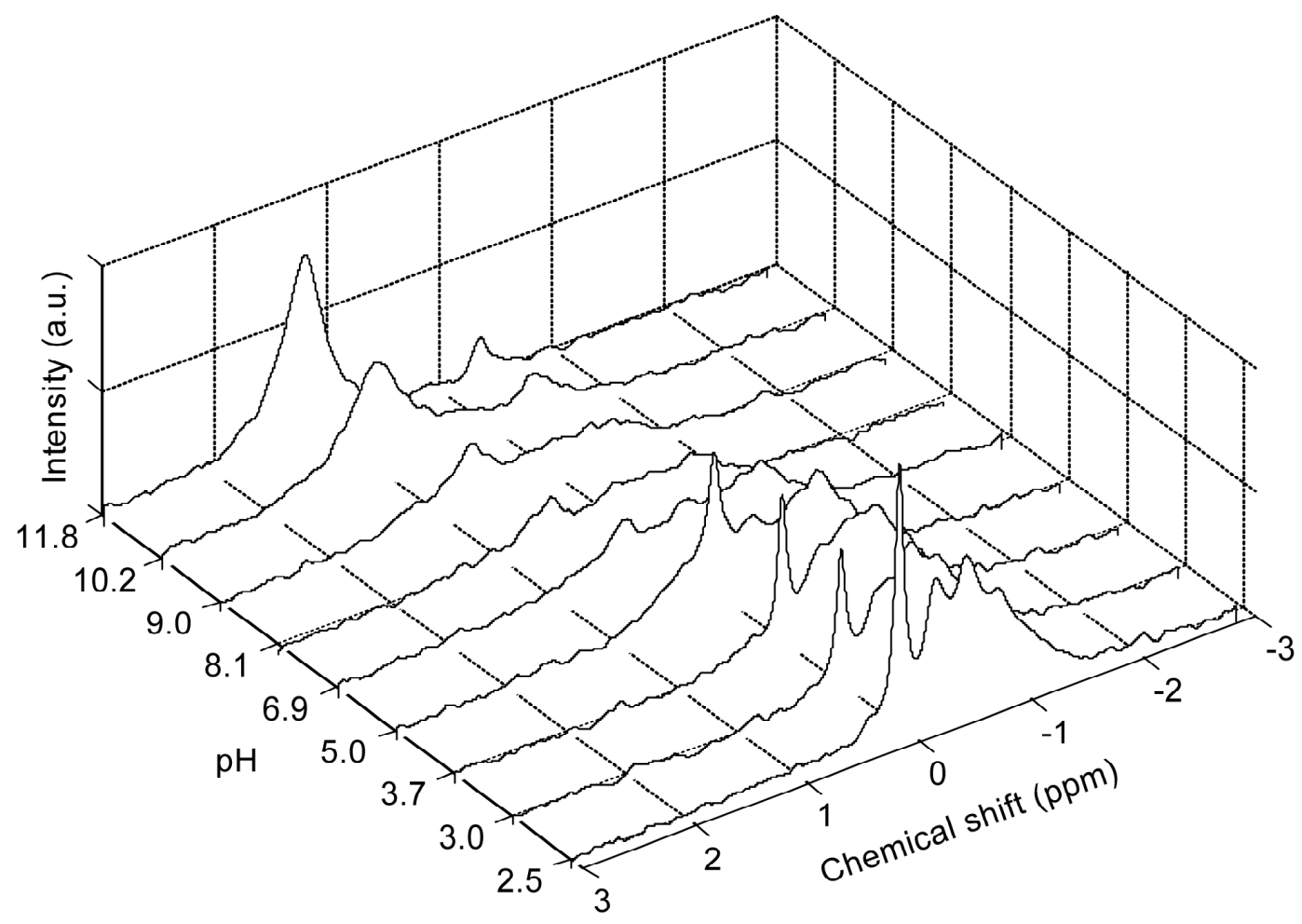

Figure 3-29. ${ }^{9} \mathrm{Be} \mathrm{NMR}$ spectra of $5 \mathrm{mM} \mathrm{BeSO}_{4}$ with $2 \mathrm{mM}$ APMDP chelator over the pH range 2.5 - 11.8 .

The ${ }^{9} \mathrm{Be}$ spectra for beryllium sulfate with the APMDP chelator over the $\mathrm{pH}$ range 2.0 to 12.0 are shown in Figure 3-29. In each of these spectra there are ${ }^{9} \mathrm{Be}$ signals arising from both free beryllium in solution and beryllium complexed with the APMDP chelator. Although the chemical shift values for the different species of beryllium-APMDP complexes are too close in values to be identified quantitatively, we were able to use results from thermodynamic modeling to make general peak assignments. The chemical shift trends for free beryllium in solution follow those observed in the experiments with beryllium sulfate over the same $\mathrm{pH}$ range (Figure 3-27). At $\mathrm{pH} 2.5,3.0$ and 3.7 the ${ }^{9} \mathrm{Be}$ spectra are characterized by a single, narrow resonance at $0 \mathrm{ppm}$ and a broad resonance between 0 and $-1 \mathrm{ppm}$. The narrow resonance at $0 \mathrm{ppm}$ is attributed to free $\mathrm{Be}^{2+}$ ions in solution and the broad resonance is attributed to an overlap of ${ }^{9} \mathrm{Be}$ signals from the $\left[\mathrm{Be}_{2}(\mathrm{APMDP})\right],\left[\mathrm{Be}_{2}(\mathrm{HAPMDP})\right]^{+}$and $[\mathrm{Be}(\mathrm{HAPMDP})]^{-}$species. At $\mathrm{pH} 5.0$, the ${ }^{9} \mathrm{Be}$ spectrum shows a peak at $0.13 \mathrm{ppm}$, attributed to the $\mathrm{Be}_{2} \mathrm{OH}^{3+}$ complex, in addition to a broad resonance between 0 and $-1 \mathrm{ppm}$. The intensity and the lineshape of the broad peak are considerably smaller and broader than for the sample at $\mathrm{pH}$ 6.9. In addition, there is a broad resonance at $0.42 \mathrm{ppm}$ assigned to $\mathrm{BeOH}^{+}$, suggesting an exchange or transition from the $\mathrm{Be}_{2} \mathrm{OH}^{3+}$ species to the $\mathrm{BeOH}^{+}$species between $\mathrm{pH} 5.0$ and 6.9. The ${ }^{9} \mathrm{Be}$ spectra at $\mathrm{pH} 8.0$ and 9.1 show a downfield shift and a broadening in the peak assigned to free beryllium due to the increase of beryllium hydroxide species in solution $\left(\mathrm{Be}(\mathrm{OH})_{2}\right.$, $\left.\mathrm{BeOH}^{+}, \mathrm{Be}(\mathrm{OH})_{3}{ }^{-}\right)$. There is also a decrease in the intensity of the broad peak between 0 
and -1 ppm as well as the appearance of a small peak near $-0.35 \mathrm{ppm}$, which has been attributed to the presence of $[\mathrm{Be}(\mathrm{APMDP})]^{-2}$. As the $\mathrm{pH}$ increases from 9.0 to 11.8 , the small peak at -0.35 shifts to $-0.4 \mathrm{ppm}$, becomes higher in intensity and narrower in lineshape. This transition indicates that as the $\mathrm{pH}$ increases from 9.0 to 11.8 , the number of Be-APMDP species in solution decreases to the single species [Be(APMDP)] ${ }^{-2}$. At the same time, the peak assigned to a combination of beryllium hydroxide species moves downfield as it becomes more intense and less broad. This also suggests that as $\mathrm{pH}$ increases, free beryllium is found more exclusively in the form of the $\mathrm{Be}(\mathrm{OH})_{3}{ }^{-}$species.

It is also important to notice that in contrast to the ${ }^{9} \mathrm{Be}$ spectra for beryllium sulfate (Figure 3-28), we were able to detect a ${ }^{9} \mathrm{Be}$ signal in the $\mathrm{pH}$ range 6-11 with the addition of the APMDP chelator. The exchange between free beryllium and the APMDP molecule in solution creates a more energetically favorable environment for free beryllium, leading to the increased solubility of beryllium over this $\mathrm{pH}$ range. The NMR results here validate the general trends in thermodynamic modeling where a variety of chelator species are available at low $\mathrm{pH}$ values, begin to narrow into a smaller range of species at more neutral $\mathrm{pH}$ values, and then taper off into one dominant species at alkaline $\mathrm{pH}$ values.

\subsection{Animal Experiments}

\section{LLNL-IBC\#2004-029.}

Two sets of animal experiments were performed. Firstly, a smaller group of mice were exposed to beryllium, APMDP and tiron, to allow a study of the effect on mice - clearly, if APMDP or the administration of beryllium or tiron were found to be harmful to the mice using our method, we would need to know using a smaller mouse group. The initial results showed that beryllium and chelator administration did not adversely affect the mice over the course of the 48-hour experiment.

Mice ( $\sim 30 \mathrm{~g}$ ) were given $0.05 \mathrm{mg}$ beryllium per $\mathrm{kg}$ followed by the chosen chelator (at $1 \mathrm{x}$ $\mathrm{Be}, 5 \mathrm{x} \mathrm{Be}$ and $10 \mathrm{x} \mathrm{Be}) 12$ hours post-beryllium exposure. Urine samples were taken every 12 hours and tissue samples were excised after termination at 72 hours. Samples were analyzed for beryllium by ICP-MS. The experiment on a larger group of mice showed that beryllium burden in tissue was decreased and beryllium urinary excretion was increased compared to the control mice. The results are shown graphically in Figures 3-30 through 3-32. No adverse health effects were observed in any of the mice over the course of the experiment. 

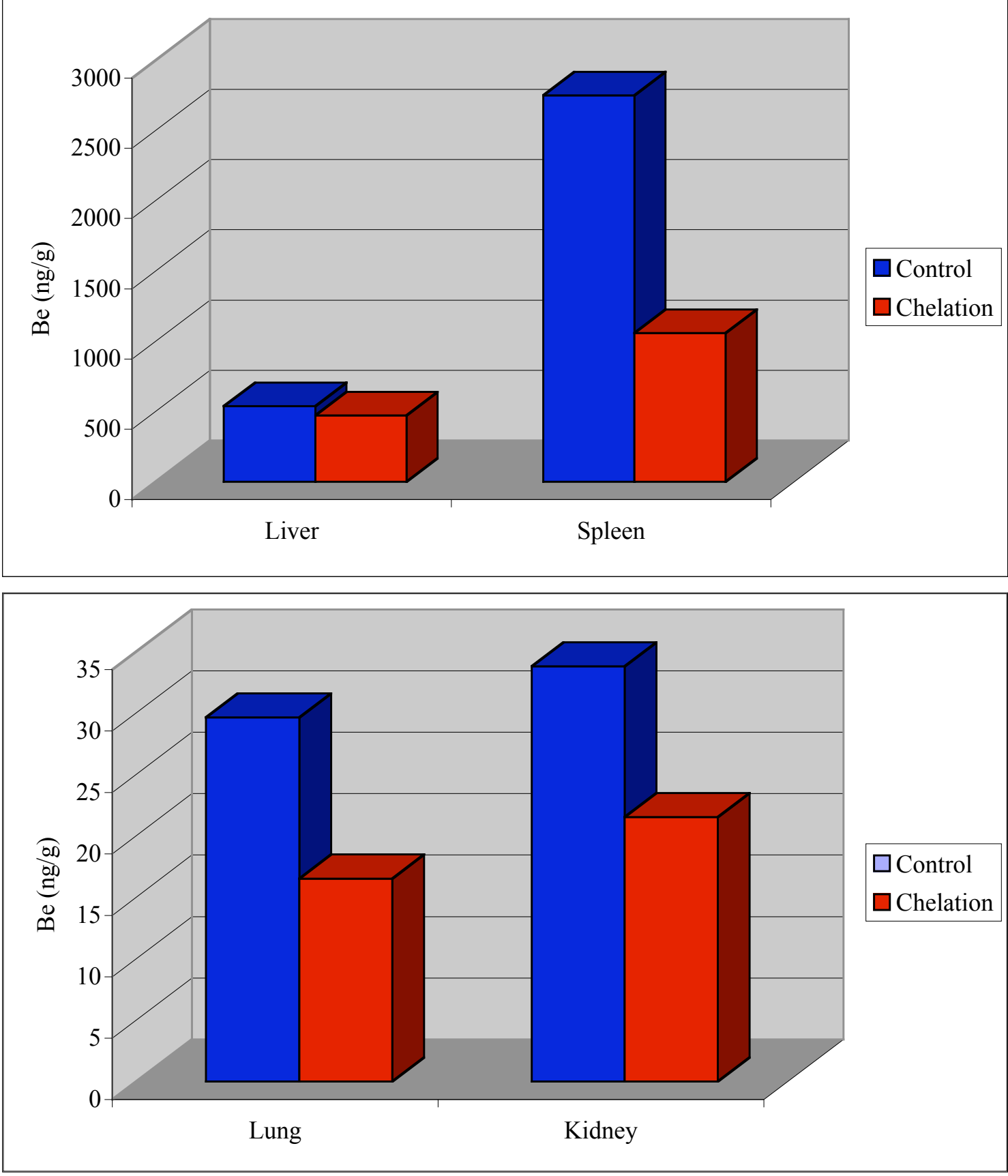

Figure 3-30. Effect of APMDP chelator on the average beryllium tissue burden in mice after 72 hours

Figure 3-30 shows that average beryllium burden in the liver, spleen, lung and kidney was reduced when APMDP chelator was administered compared with an group of control mice. 


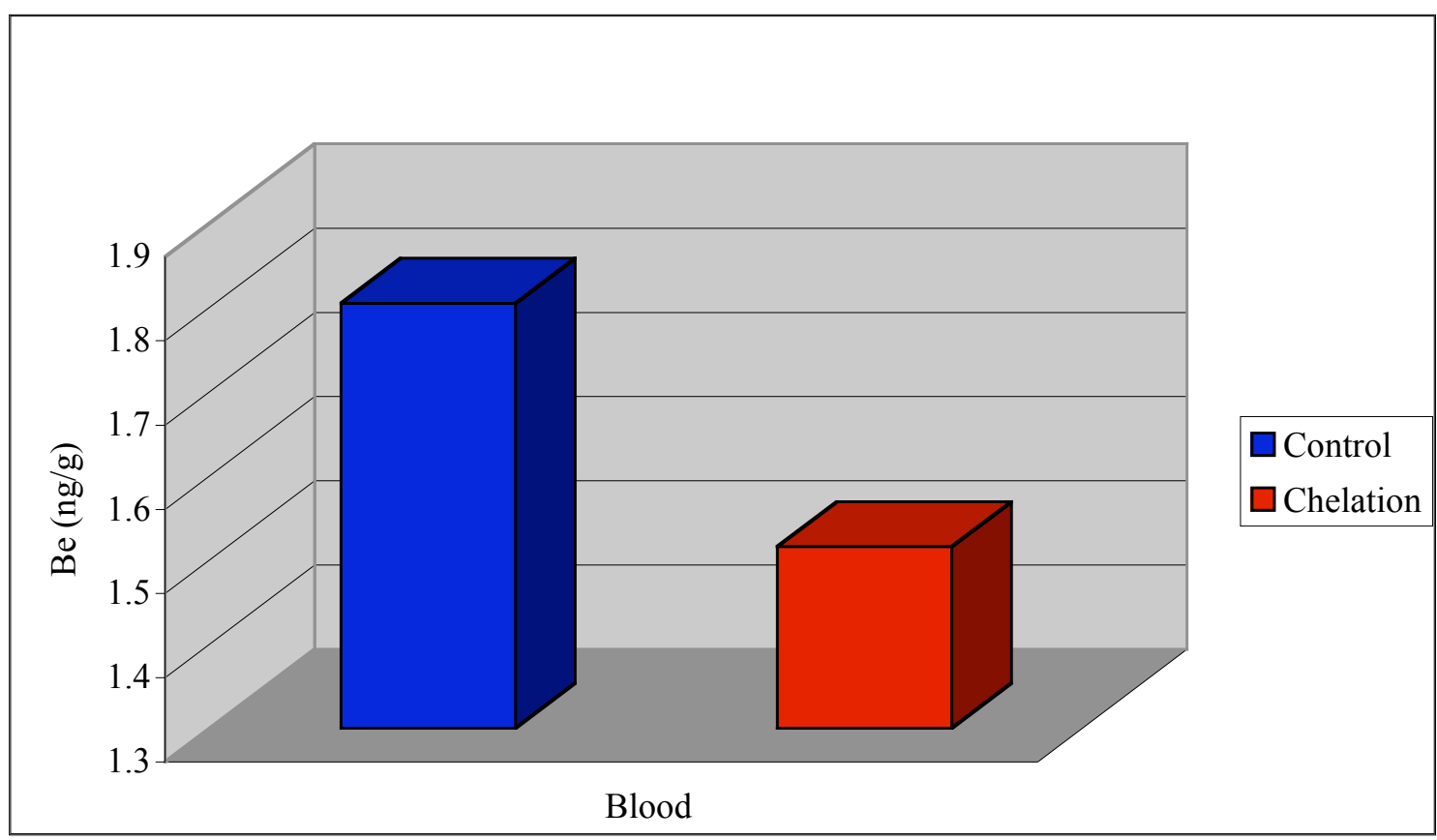

Figure 3-31. Effect of APMDP chelator on the average beryllium concentration in mouse

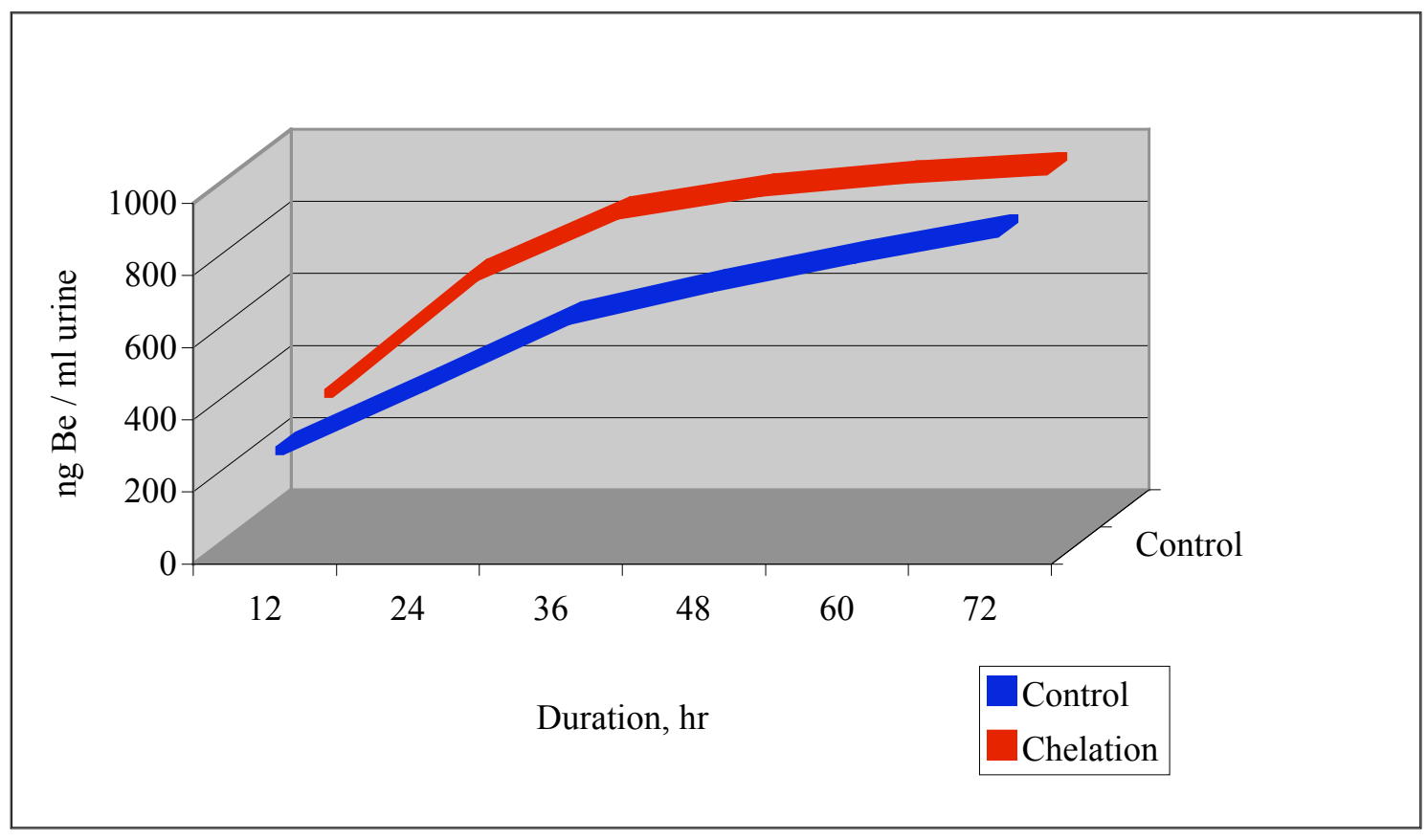

blood after 72 hours.

Figure 3-32. Effect of APMDP chelator on the average cumulative beryllium urinary excretion in mice.

Figure 3-31 shows that beryllium blood burden was decreased on average after chelator administration, while figure 3-32 shows that cumulative beryllium urinary excretion was increased following chelator administration compared to control mice. 


\subsection{SIMS Analysis}

It has long been hypothesized that imagine of beryllium in a lung biopsy would allow pulmonologists to observe the presence of beryllium in alveolar macrophages. Work by Levi-Setti et al (Biol. Cell. 63, 1988, 77-82) has shown that beryllium can be imaged using Secondary Ion Mass Spec (SIMS). Lawrence Livermore National Laboratory is one of only two research establishments in the United States to own a nano-SIMS instrument, capable of imaging samples at the nanometer resolution.

A sample of mouse spleen was harvested during the animal experiments detailed in Section 3.6 above. The spleen was cryomicrotomed before SIMS analysis. The results showed that beryllium was clearly visible and incorporated in regions of sodium abundance. Be localized in sample with $\sim 700 \mathrm{ppb}$ bulk Be. Be detected in sample with $\sim 10 \mathrm{ppb}$ bulk Be. Unfortunately, the instrument has not yet been tuned finely enough to allow nanometer resolution, but the image in Figure 3-33 clearly shows the potential.

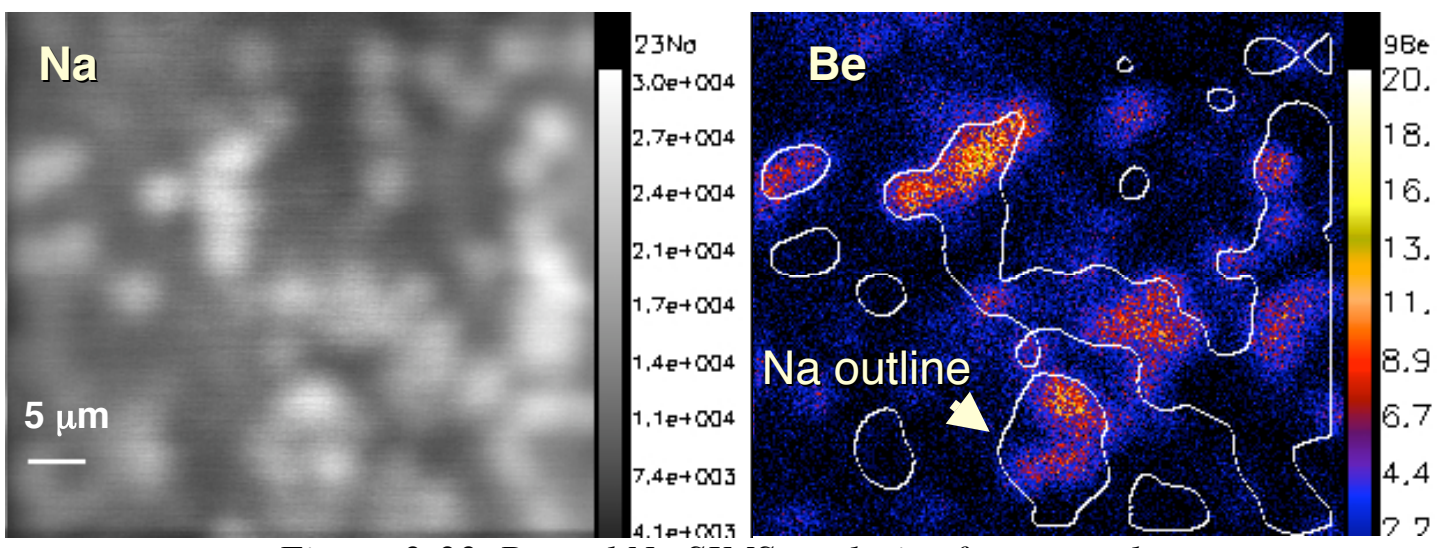

Figure 3-33. Be and Na SIMS analysis of mouse spleen.

\subsection{Site-300 Beryllium Particle Dissolution Studies}

The aims of this investigation were not limited to the study of beryllium in biological fluids and systems. A good chelator in the body is likely a good chelator in the environment. To prove the effectiveness of our chelator on environmental samples, and to prove that chelation could in fact dissolve and bind beryllium oxide, we investigated the effect of APMDP on BeO debris from a test shot at the LLNL Site 300 Contained Firing Facility (CFF). Particles were obtained from the Contained Firing Facility (CFF) at LLNL Site 300 and had previously been characterized (Table 3-2).

\begin{tabular}{|l|c|c|c|c|c|c|c|}
\hline Element & Fe & Cu & Zn & Be & Mn & Ni & Pb \\
\hline $\mathrm{mg} / \mathrm{g}$ & 409 & 21 & 8.6 & 4.95 & 3.6 & 0.19 & 2 \\
\hline
\end{tabular}

Table 3-2. Elemental composition of LLNL Site 300 CFF particles.

This work was performed in a designated ventilation box in Bld 253, capable of handling beryllium oxide fine particles. Swipe samples before and after experimental investigations showed no beryllium contamination had been generated.

Approximately 500mg of beryllium oxide debris was weighed in a tared polyethylene vials and varying concentrations of APMDP chelator ( $\mathrm{pH}$ adjusted to $\mathrm{pH} 7$ ) were added 
to each vial. The vials were left to stand for 3 days, with manual shaking performed for 2 minutes each, twice a day. Samples were then filtered through a 0.2 um membrane and filtrates were analyzed by ICP-MS. The results are shown in Figure 3-34, and clearly demonstrate a linear concentration profile, indicating that APMDP dissolves and binds beryllium (in this case) at a 1:1 ratio at $\mathrm{pH} 7$. While samples were equilibrated for 3 days, the results indicate that insoluble $\mathrm{BeO}$ fines can be dissolved by APMDP chelator.

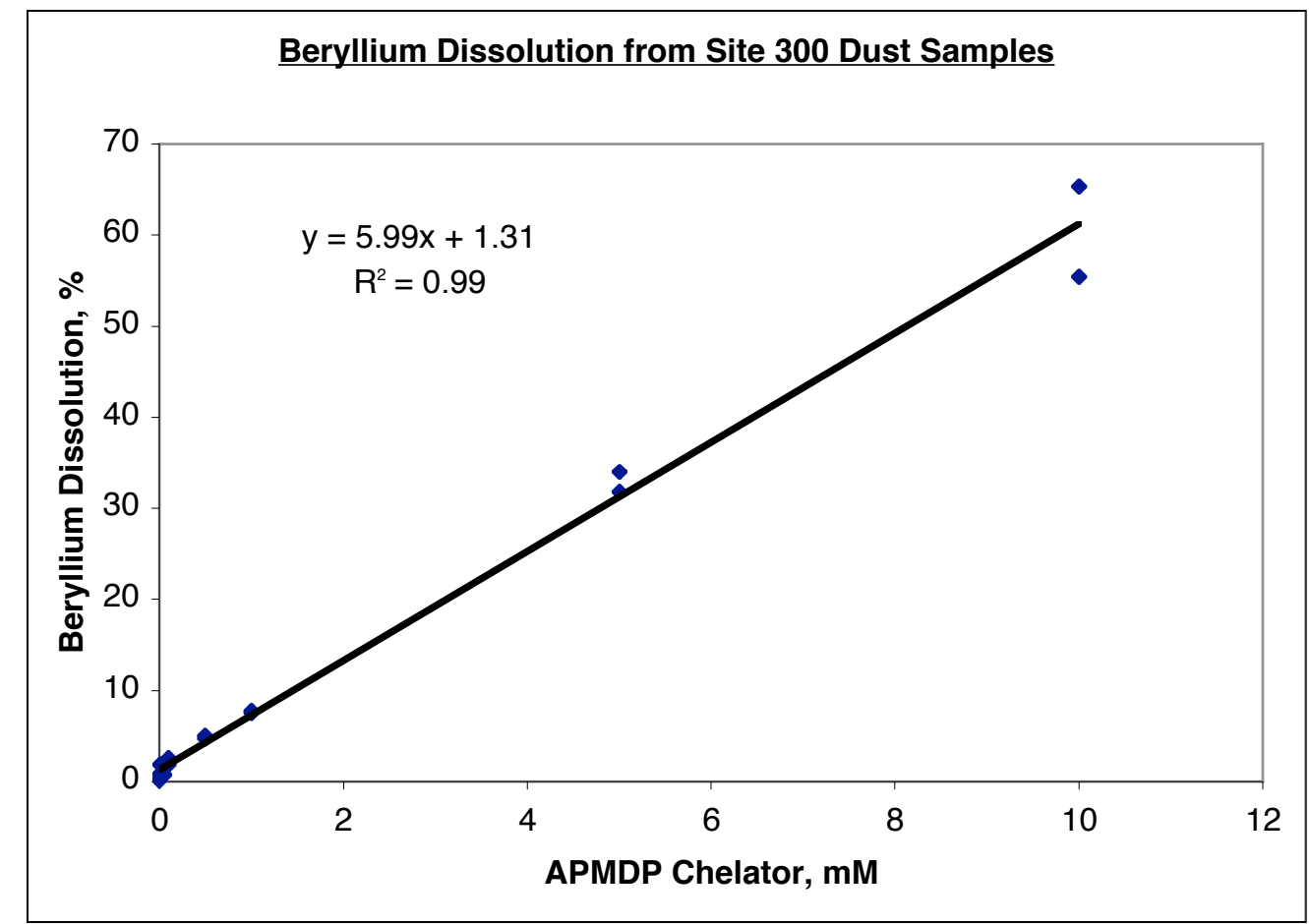

Figure 3-34. Effect of chelator concentration on Site 300 beryllium sample dissolution

\subsection{Structural Modeling}
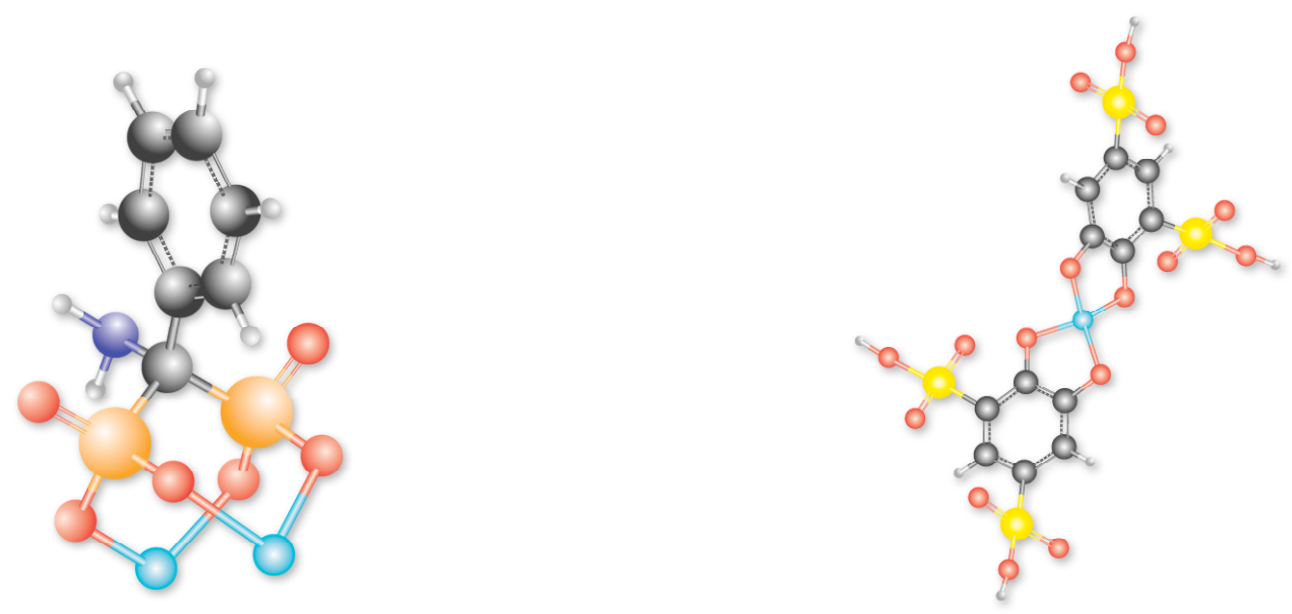

Figure 3-35 and 3-36. Structural models of Be ${ }_{2} A P M D P$ and Be(Tiron $)_{2}$. 
4

Beryllium Interaction with Aerogel/GAC 


\section{Beryllium Interaction with Aerogel/GAC}

\subsection{Introduction}

Beryllium is a corrosion resistant, low density, thermally absorbing, electrically insulating, neutron moderating element. It is used in industry in a variety of forms metal, oxides and alloys, for the manufacture of materials ranging from nuclear components and electronics to golf clubs and aircraft brakes. Beryllium components are widely machined and used throughout the Department of Energy (DOE) and Department of Defense (DOD). Unfortunately, beryllium is also one of the most toxic elements and is a Class A carcinogen - known to cause human cancer (1). Exposure to beryllium can cause beryllium sensitization, and Chronic Beryllium Disease (CBD), a currently incurable and often-fatal immunologic lung disease (2). In 2003, the projected increase in world beryllium consumption was $2 \%$ per year (3). Increased use of beryllium in industry creates increased threat of pollution in the workplace and environment, including during the recycling of electronic components containing beryllium. For example, environmental contamination is a problem at the DOE Rocky Flats site where beryllium was previously machined and disposed of (4). As such, OSHA has implemented a rule of $2 \mathrm{ug} / \mathrm{m} 3$ personal exposure limit (5) and DOE has implemented the Chronic Beryllium Disease Prevention Program (6) to limit and document beryllium exposure in the United States.

There is currently a lack of information pertaining to beryllium environmental contamination (7). The US-EPA has set strict drinking water standards of $4 \mathrm{ug} / \mathrm{L}$, second only to mercury and thallium (8). A beryllium concentration in Saudi Arabian tap water was measured at $0.128 \mathrm{ug} / \mathrm{L}$ (9) and beryllium in US drinking water at 0.01 to $0.7 \mathrm{ug} / \mathrm{L}$ (10).

Beryllium is highly mobile in river waters that are acidic and organic-rich (11). The Delaware and Hudson rivers have been found to contain $0.1 \mathrm{ug} / \mathrm{L} \mathrm{Be}(12)$, while concentrations in the Orinoco Basin range from $0.4-52 \mathrm{ng} / \mathrm{L}$ (13). Czech groundwater and stream-water contain $1.5-3.3 \mathrm{ug} / \mathrm{L}$ (14) and beryllium concentrations in soils range from $0.1 \mathrm{mg} / \mathrm{kg}$ to $40 \mathrm{mg} / \mathrm{kg}$ (15). Beryllium contamination related to mining activities has also led to increased beryllium in the environment (16) and an explosion at a nuclear fuel processing plant in the former Soviet Union led to an atmospheric release of several tons of beryllium (17). Reducing the risks of beryllium exposure to workers and the public is an important first step towards limiting beryllium sensitization and CBD. A cheap, simple and effective cleanup method is required to meet these growing needs and concerns.

Adsorption can be described as a concentration enhancement of one phase at the interface of another. Chemical sorption (often termed 'chemisorption') is, as one would expect, a chemical interaction between the solution (solute) and the surface (sorbent). Charged surfaces can arise either from a chemical reaction of ionizable groups at the surface or, from lattice imperfections. Activated carbon materials have been used for many years as sorbents because of the low cost, high surface area, low density and ease of manufacture. The absorptive properties of carbonaceous materials date back as far as 1550 B.C. when charcoal was used in Egyptian medicinal treatment (18). Modern commercial production of activated carbons was developed in 1900 (19) and recent examples of GAC use in 
remediation include heavy metals and volatile organic carbons (VOC) $(20,21)$. However, GAC is not selective, and will bind a variety of contaminants, thus reducing its efficiency.

Silica aerogels are open-cell polymers with unique properties - they have the highest internal surface area per gram of any known material and the best electrical, thermal and sound insulation properties of any known solid $(22,23)$. GAC can be added to silica aerogels to aid manageability and reduce handling difficulties associated with the very low density and hydrophobic nature of aerogels. This also has the added effect of utilizing (and improving upon) the sorptive properties of GAC. Silica aerogels can extract a variety of contaminants such as organics, petroleum products and metals. Aerogels have been used in mineral extraction, oil extraction cleanup, gaseous pollutant scrubbing, and the remediation of radioactive and mixed hazardous wastes $(22,24,25,26,27,28)$. Functionalizing aerogel to incorporate chemical sites that selectively bind the metal of interest are key to improving the efficiency of aerogel/GAC material for specific environmental remediation activities. Aerogel/GAC material has been used to remove uranium and chromium from waste streams and environmental waters $(24,29)$, and has shown how functionalizing aerogel can improve its efficiency. Highly selective beryllium chelators have been investigated $(30,31)$ that could be incorporated into the chemical or physical structure of aerogel to increase its effectiveness. Before such incorporations are made, the full characterization of beryllium interactions with aerogel/GAC material is required. This work provides a baseline study of beryllium adsorption on aerogel/GAC material.

Traditionally, chemical thermodynamic computer modeling, has been used to study metal contaminant environmental chemistry $(32,33)$. Information on the speciation of metals not only allows a study of the chemistry of the metal in various chemical systems (34), but also the physical nature of the metal - namely its ionic charge, solubility and sorption behavior (35). Furthermore, ${ }^{9} \mathrm{Be}$ is diamagnetic, and therefore can be detected by nuclear magnetic resonance (NMR). This technique has been used by several researchers to understand changes in beryllium speciation with chemical environment (36-40).

The specific aims of this study were to characterize the sorption of beryllium onto aerogel-GAC material with respect to the rate of sorption, type of sorption, effect of $\mathrm{pH}$ and aerogel:beryllium ratio were also under investigation. Computer modeling using the MINTEQA2 speciation code (41) and ${ }^{9} \mathrm{Be}$ NMR were used to understand the sorption of beryllium over a range of $\mathrm{pH}$ values.

\subsection{Experimental}

\subsubsection{Preparation of the aerogel-GAC material (42)}

The GAC material was outgassed at $300{ }^{\circ} \mathrm{C}$ for four hours in a stainless steel furnace housing an oxidizing atmosphere to remove solvent contamination. A solution of tetramethyl orthosilicate, 3,3,3-trifluorpropyl-trimethoxysilane and methanol was slowly added to a solution containing water, methyl alcohol, phosphoric acid and 
tetrafluoroboric acid. The outgassed GAC was slowly added to the mixed solutions and stirred. The resulting mixture was placed in a vacuum chamber that was then evacuated until most of the air bubbles burst. The mixture was then transferred into a stainless steel mold until completely full. Once sealed, the mold was placed into a high-pressure reactor and heated to $300{ }^{\circ} \mathrm{C}$ while maintaining supercritical conditions for methanol. Once the reaction was complete, the resulting aerogel-GAC molding was crushed into pieces of a size similar to the original GAC material before sorption experiments were performed.

\subsubsection{Physical characterization}

Surface area and pore volume and size analyses were performed using a surface area analyzer (ASAP 2000, Micromeritics Instrument Corporation) with resulting data analyzed by the BET (Brunauer-Emmett-Teller) method. Samples of aerogel $(0.1-0.2$ g) were heated to $200{ }^{\circ} \mathrm{C}$ under vacuum (10 mTorr) for at least 24 hours to remove all adsorbed species. Nitrogen adsorption data was taken at five relative pressures from 0.05 to 0.20 atmospheres at $77 \mathrm{~K}$, to calculate the surface area using the BET theory.

\subsubsection{Balance and pipette certification}

All mass measurements were made using a Mettler Toledo balance performance checked against a NIST traceable weight set (Heusser Neweigh). Solution volumes were dispensed using air displacement pipettes (Gilson), performance checked against the NIST traceable balance and weights at room temperature with MilliQ water and corrected for fluctuations in temperature. Beryllium sulfate tetrahydrate (J.T. Baker, $99.9 \%$ ) was used throughout this work.

\subsubsection{Potentiometric titration of aerogel-GAC material}

The point of zero charge $\left(\mathrm{pH}_{\mathrm{PZC}}\right)$ is defined as the $\mathrm{pH}$ at which the surface charge on the sorbent is zero. The $\mathrm{pH}_{\mathrm{PZC}}$ for aerogel-GAC material was determined by automated addition of acid and base (Metrohm autotitrator) while measuring the solution potential (Metrohm sat. $\mathrm{KCl}$ electrode) in a stirred reaction vessel under an $\mathrm{N}_{2}$ atmosphere. A $1 \mathrm{~g}$ sample of aerogel-GAC material was placed in $20 \mathrm{~mL}$ of MilliQ deionized water and the system was purged with nitrogen gas. With continuously stirring, $0.001 \mathrm{M}, 0.01 \mathrm{M}$ and $0.1 \mathrm{M}$ hydrochloric acid (0.1 M stock, NIST SRM standardized at $25^{\circ} \mathrm{C}$ against TRIS, $\pm 0.0002 \mathrm{M}$, Titristar, EM Science) was titrated into the vessel and the $\mathrm{pH}$ was recorded and compared to a $\mathrm{pH}$ profile made with MilliQ deionized water in the absence of aerogel-GAC material. The experiment was repeated using $0.001 \mathrm{M}, 0.01 \mathrm{M}, 0.1 \mathrm{M}$ sodium hydroxide $\left(0.1 \mathrm{M}\right.$ stock solution, NIST SRM standardized at $25^{\circ} \mathrm{C}$ against potassium phthalate, $\pm 0.0002 \mathrm{M}$, Titristar, EM Science). The results of the titration were then compared to a titration of pure MilliQ deionized water containing no aerogel-GAC material. The point of zero charge was determined as the point of intersection of each potentiometric titration curve for aerogel-GAC against $0.001,0.01$ and $0.1 \mathrm{M}$ acid / base. 


\subsubsection{Analysis of beryllium}

Aliquots of each sample were taken and an internal standard spike of Li-6 was added. Samples were diluted to a volume of $10 \mathrm{~mL}$ with MilliQ and $2 \%$ nitric acid (baseline high purity, $<0.005 \mathrm{ppb} \mathrm{Be},<0.001 \mathrm{ppb} \mathrm{Li}$, Seastar Chemicals) so as to bring the analytical beryllium concentration of the sample within the range of $0.1-2.5 \mathrm{ppb}$. Samples were analyzed on a single collector quadrupole inductively coupled plasma mass spectrometer (ICP-MS, Agilent 4500). Calibration curves were generated using the on-board software (HP Chemstation) using multipoint calibration from $0-5 \mathrm{ppb}$ Be and $100 \mathrm{ppb}$ Li-6 internal standard.

\subsubsection{Beryllium-aerogel-GAC sorption isotherms}

At the low beryllium concentrations used in this sorption study, beryllium is below the saturation concentration and therefore no beryllium hydroxide / oxide precipitates are present and only monomeric aqueous beryllium hydroxide species are assumed to dominate the hydrolysis. Aliquots of beryllium $(20 \mathrm{~mL}$ of $1 \mu \mathrm{M}$ in MilliQ deionized water) were added to increasing amounts aerogel-GAC material (from $5 \mathrm{mg}$ to $1000 \mathrm{mg}$ ) in $20 \mathrm{~mL}$ sealed glass vials. The vials were then continually shaken at $150 \mathrm{rpm}$ in an orbital shaker (LabLine) for 6 days before sampling and filtering the supernatant through a $0.45 \mu \mathrm{m}$ Acrodisc filter (Gelman Sciences) followed by a $0.2 \mu \mathrm{m}$ Acrodisc filter. Each filtrate sample was diluted and analyzed using ICP-MS. The beryllium concentration was compared with a blank sorption standard that contained beryllium without aerogel-GAC material.

\subsubsection{Sorption $\mathrm{pH}$ isotherms}

The $\mathrm{pH}$ of aliquots of beryllium ( $20 \mathrm{~mL}$ of $1 \mu \mathrm{M}$ in MilliQ deionized water) were adjusted by addition of $0.1 \mathrm{M} \mathrm{HCl}$ or $0.1 \mathrm{M} \mathrm{NaOH}$ and added to $100 \mathrm{mg}$ of aerogel-GAC material in $20 \mathrm{~mL}$ sealed glass vials. Samples were continually shaken at $150 \mathrm{rpm}$ in an orbital shaker for 6 days before being filtered through a $0.45 \mu \mathrm{m}$ Acrodisc syringe filter membrane, followed by a $0.2 \mu \mathrm{m}$ Acrodisc filter. The final $\mathrm{pH}$ of each solution was measured using a ROSS combination electrode (Orion) and a digital $\mathrm{pH}$ meter (Orion), and samples were then analyzed for beryllium by ICP-MS.

\subsubsection{Rate of beryllium sorption on aerogel-GAC material}

The rate of beryllium sorption on to aerogel-GAC material was studied by analysis of replicate samples over the course of one week. Aliquots of beryllium $(20 \mathrm{~mL}$ of $1 \mu \mathrm{M}$ in MilliQ deionized water) were added to $100 \mathrm{mg}$ of aerogel-GAC material in $20 \mathrm{~mL}$ sealed glass vials. Samples were continually shaken at $150 \mathrm{rpm}$ in an orbital shaker and removed in duplicate after 2, 10, 30 minutes, 1, 4, 9 hours and 1, 3,6 days. Each sample was filtered through a $0.45 \mu \mathrm{m}$ Acrodisc filter followed by a $0.2 \mu \mathrm{m}$ Acrodisc filter, and filtrates were then analyzed using ICP-MS. The beryllium concentration was compared with a blank sorption standard that contained beryllium without aerogel-GAC material. 


\subsection{Results and Discussion}

\subsubsection{Physical characterization and point of zero charge}

The physical characterization of the aerogel/GAC material is summarized in Table 1, together with reference values for GAC, aerogel and GAC/Aerogel composite material. BET surface analysis of the aerogel-GAC composite material showed a high specific surface area, $637.9 \mathrm{~m}^{2} / \mathrm{g}$, with a pore volume of $0.30 \mathrm{~cm}^{3} / \mathrm{g}$ and a pore diameter of 5.8 $\mathrm{nm}$. The potentiometric titration of the aerogel-GAC material in MilliQ deionized water sample with standardized acid and base yields information on the neutralization of the surface charge. The point of zero charge, $\mathrm{pH}_{\mathrm{PZC}}$, was 4.1 , thus, at $\mathrm{pH}$ values less than 4.1, the surface charge on the aerogel-GAC material is expected to be increasingly positive, while above $\mathrm{pH} 4.1$ the net surface charge is expected to be increasingly negative.

\begin{tabular}{|l|l|l|}
\hline & GAC & Aerogel/GAC Composite \\
\hline Surface Area, $\mathrm{m}^{2} / \mathrm{g}$ & $739(24)$ & $978(24)$ \\
& $808-1075(43)$ & $637.9 \#$ \\
& $294-1745(44)$ & \\
\hline Pore Volume, $\mathrm{cm}^{3} / \mathrm{g}$ & $0.2-1.3(44)$ & $0.30 \#$ \\
\hline Pore Diameter, $\mathrm{nm}$ & $4.0(24)$ & $6.8(24)$ \\
& $2.0-3.8(44)$ & $5.8 \#$ \\
\hline $\mathrm{pH}_{\mathrm{PZC}}$ & $2.2-10.4(43,45-49)$ & $4.1 \#$ \\
\hline Composition $(\mathrm{wt} \%)$ & $(24)$ & $(24)$ \\
$\mathrm{C}$ & 85.4 & 78.4 \\
$\mathrm{H}$ & 0.5 & 1.1 \\
$\mathrm{P}$ & 0.3 & 0.1 \\
$\mathrm{Si}$ & - & 4.1 \\
$\mathrm{~F}$ & - & 1.7 \\
\hline
\end{tabular}

Table 4-1. Physical and chemical properties of GAC, aerogel/GAC composite materials. ${ }^{\#}$ This work

\subsubsection{Beryllium-aerogel-GAC sorption isotherms}

The results of the beryllium sorption isotherm studies can be plotted in a variety of ways, each one giving different information about the sorption of beryllium onto aerogel-GAC material. The standard 'linear-type' sorption isotherm plots of the concentration of beryllium sorbed onto aerogel against the concentration of beryllium in solution are shown in Figure 1 and show that beryllium sorption is favorable and follows the linear equation,

$$
\mathrm{C}_{\mathrm{s}}=\mathrm{R}_{\mathrm{d}} \cdot \mathrm{C}_{1}
$$

Linear-type relationships are discovered and the gradient yields a $\mathrm{K}_{\mathrm{d}}$ sorption value of $597.2 \mathrm{~mL} / \mathrm{g}$. The isotherm shows evidence of a plateau or deviation from linearity in the latter half of the linear isotherm plot, i.e. saturation, suggesting that the sorption isotherms cannot be described as linear. This compares to between $1,700-2,400 \mathrm{~mL} / \mathrm{g}$ and $300-400 \mathrm{~mL} / \mathrm{g}$ for beryllium binding on Biotite and Albite respectively at $\mathrm{pH} 7$ depending 
on grain size (50). Beryllium separation on Dowex 50 and Dowex A-1 resin resulted in $\mathrm{K}_{\mathrm{d}}$ values of 1650 (51) and 1000 (52) respectively. Additionally, beryllium sorption on a functionalized fibrous sorbent (53) yielding $\mathrm{K}_{\mathrm{d}}$ values of 10,000 at $\mathrm{pH} 5$.

Freundlich isotherms (Ref 54) are applicable to heterogeneous sorption surfaces and can be described by equations (2) and (3). The characterization of sorption by Freundlich sorption theory is shown graphically in Figure 2.

$$
q=K_{F} \cdot C^{n} \quad(2) \quad \text { and therefore, } \quad \log _{10} q=n \log _{10} C+\log _{10} K_{F}
$$

Examination of the sorption isotherms using Freundlich sorption theory yields both the Freundlich sorption constant, $\mathrm{K}_{\mathrm{F}}$ (taken from the intercept on the $\mathrm{y}$-axis) and the sorption order constant, $\mathrm{n}$, (taken from the gradient). For beryllium sorption onto aerogel-GAC material, $\log _{10} \mathrm{~K}_{\mathrm{F}}=13.22\left(\mathrm{~K}_{\mathrm{F}}=1.66 \times 10^{7} \mathrm{~mol} / \mathrm{ug}\right)$ and $\mathrm{n}=2.13$.

Previous studies showed that beryllium was found to sorb with poor selectivity and reproducibility to GAC material (55) with a maximum of $80 \%$ recovery between $\mathrm{pH} 7.0$ and 9.0, resulting in $\mathrm{K}_{\mathrm{f}}=3.2 \times 10^{2}$ and $\mathrm{n}=0.5$. 


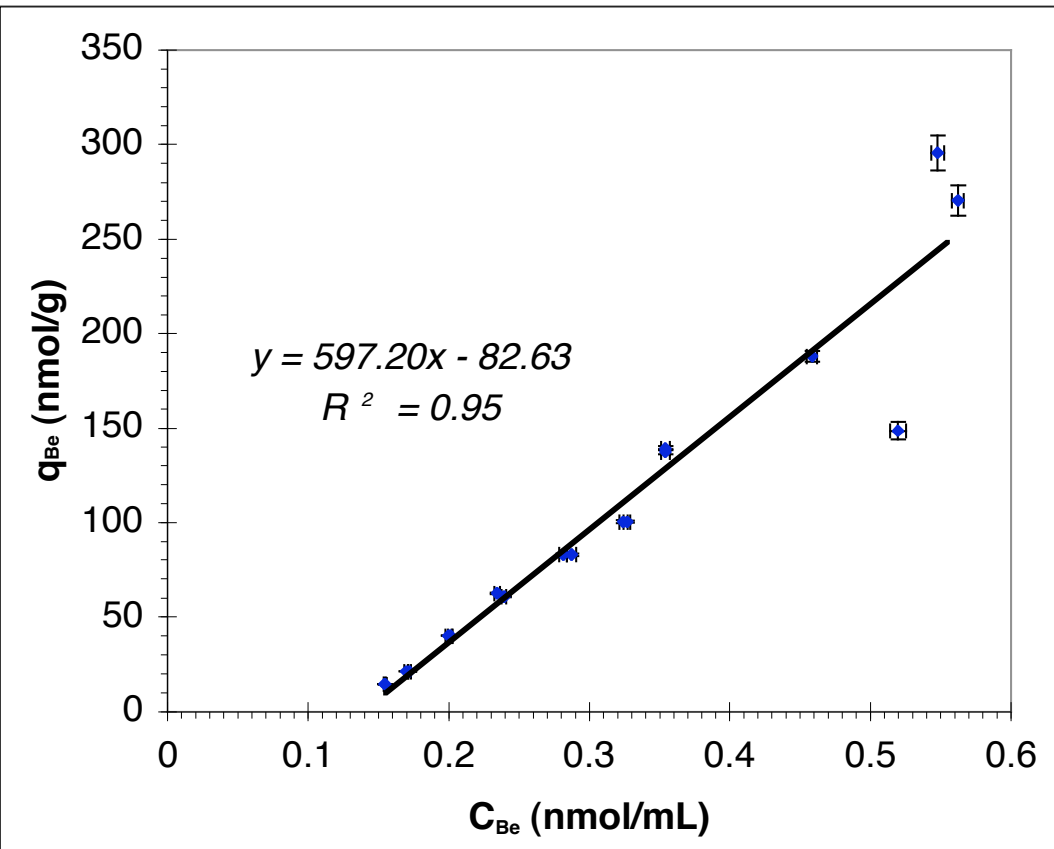

Figure 4-1. Linear sorption isotherm for beryllium-aerogel/GAC material

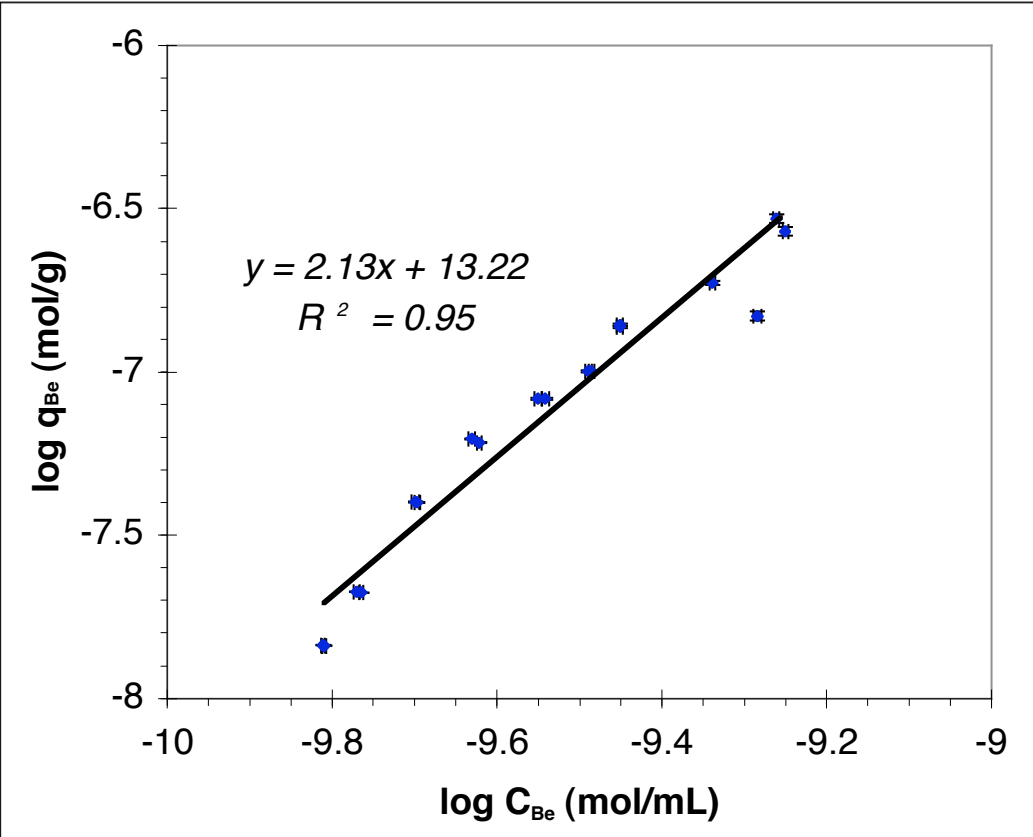

Figure 4-2. Freundlich sorption isotherm for beryllium-aerogel/GAC material 


\subsubsection{Rate of beryllium sorption}

A study of the rate of sorption of beryllium onto aerogel-GAC material shows two apparent stages, the first being fast sorption of beryllium and the second sorption at a slower rate. This can be investigated further by studying the rate constants for the sorption.

The rate of sorption can be expressed as a function of changing unbound beryllium in solution, $\mathrm{C}_{\mathrm{t}}\left(\mathrm{mol}^{-1} \mathrm{l}^{-1}\right)$ at time, $\mathrm{t}$, compared to the maximum sorption achieved, $\mathrm{C}_{\mathrm{s}} \max \left(\right.$ mol.1 $\mathrm{l}^{-}$ $\left.{ }^{1}\right)$ and the rate constant, $\mathrm{k}_{\mathrm{t}}\left(\mathrm{s}^{-1}\right)$,

$$
\frac{\mathrm{dC}}{\mathrm{dt}}=\mathrm{k}_{\mathrm{t}} \cdot\left(\mathrm{C}_{\mathrm{t}}-\mathrm{C}_{\mathrm{s}} \max \right)
$$

Integration of the above rate equation allows determination of the sorption rate constant,

$$
\ln \left(\frac{1}{1-\left(\frac{C_{t}}{C_{s} \max }\right)}\right)=k_{t} \cdot \mathrm{t}
$$

and so a plot of the left-hand side of the equation against time should be linear and yield a gradient numerically equal to the rate constant. This has been performed for the sorption of beryllium onto aerogel-GAC material at high $\mathrm{pH}$ and is shown in Figure 3.

A plot of Eqn (4) did not yield a linear slope, suggesting that sorption kinetics are variable throughout the time period of the experiments. The rate appear to be somewhat slower than that observed by Ramesh et al (56) for beryllium binding on Zeolite and Bentonite, who saw almost complete binding within 120 minutes.

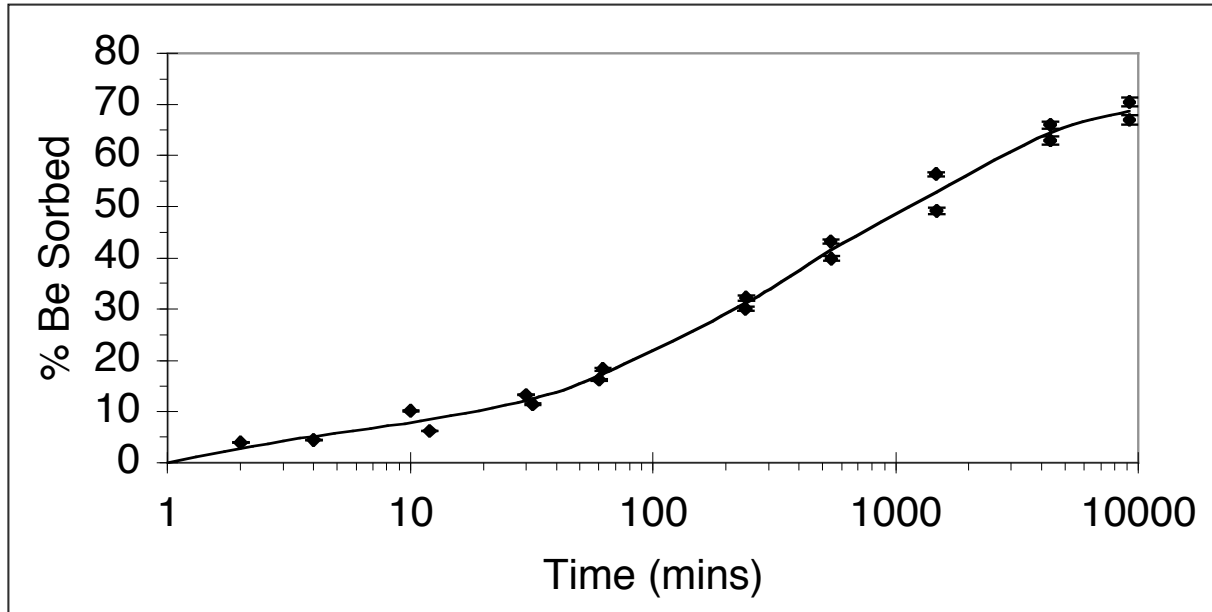

Figure 4-3. Beryllium sorption onto aerogel/GAC material over time 


\subsection{4 $\mathrm{pH}$ effects on beryllium sorption}

The results of the $\mathrm{pH}$ isotherm studies are shown in Figure 4-4, where the experimentally measured sorption is plotted against the $\mathrm{pH}$ and compared to the modeled speciation using the MINTEQA2 code. It can be seen that beryllium sorbs to the aerogel-GAC material over a variety of $\mathrm{pH}$ values studied. At $\mathrm{pH}$ values less than 4.1 (point of zero charge) it is clear that beryllium does not sorb to aerogel-GAC material. This observation is expected since thermodynamic modeling shows that the major beryllium species is the positively charged $\mathrm{Be}^{2+}$ ion, which would be repelled by the positively charged aerogelGAC surface. As the measured experimental $\mathrm{pH}$ increases to above the surface point of zero charge, we see moderate sorption of beryllium corresponding to $\mathrm{BeOH}^{+}$ions attracted to a net negative surface. At approximately $\mathrm{pH} 8$, almost $100 \%$ of the beryllium has sorbed to the aerogel-GAC surface. These results initially suggest physi-sorption (electrostatic interaction) as a potential mechanism for beryllium binding on aerogelGAC material. As the $\mathrm{pH}$ increases above $\mathrm{pH} 8$, the neutrally charged $\mathrm{Be}(\mathrm{OH})_{2}$ ion becomes the dominant aqueous species and the relative amount of beryllium sorbed to the surface drops slightly. However, above $\mathrm{pH} \mathrm{9,} \mathrm{the} \mathrm{thermodynamic} \mathrm{predictions} \mathrm{of}$ beryllium speciation show that the negatively charged $\mathrm{Be}(\mathrm{OH})_{3}{ }^{-}$species becomes the dominant beryllium ion in solution. Normally, one would not expect to see a negatively charged ion binding to a negative surface. Here we can eliminate physi-sorption as a potential mechanism for beryllium binding on aerogel-GAC material above $\mathrm{pH} 8$, in favor of chemi-sorption (binding through a chemical reaction between the surface and the sorbate). This latter statement is further supported by the decrease in beryllium sorption above $\mathrm{pH}$ 11.5, where the $\mathrm{Be}(\mathrm{OH})_{4}{ }^{2-}$ ion begins to form. In this case, all four of the tetrahedral beryllium bonds are already taken up with hydroxide groups so no further bonds can be formed, and that the ion is more stable at such a high $\mathrm{pH}$ than a corresponding $\mathrm{Be}(\mathrm{OH})_{3}{ }^{-}$ion bound to the surface would be. The mechanism for binding is more clearly illustrated in Figure 4-4b.

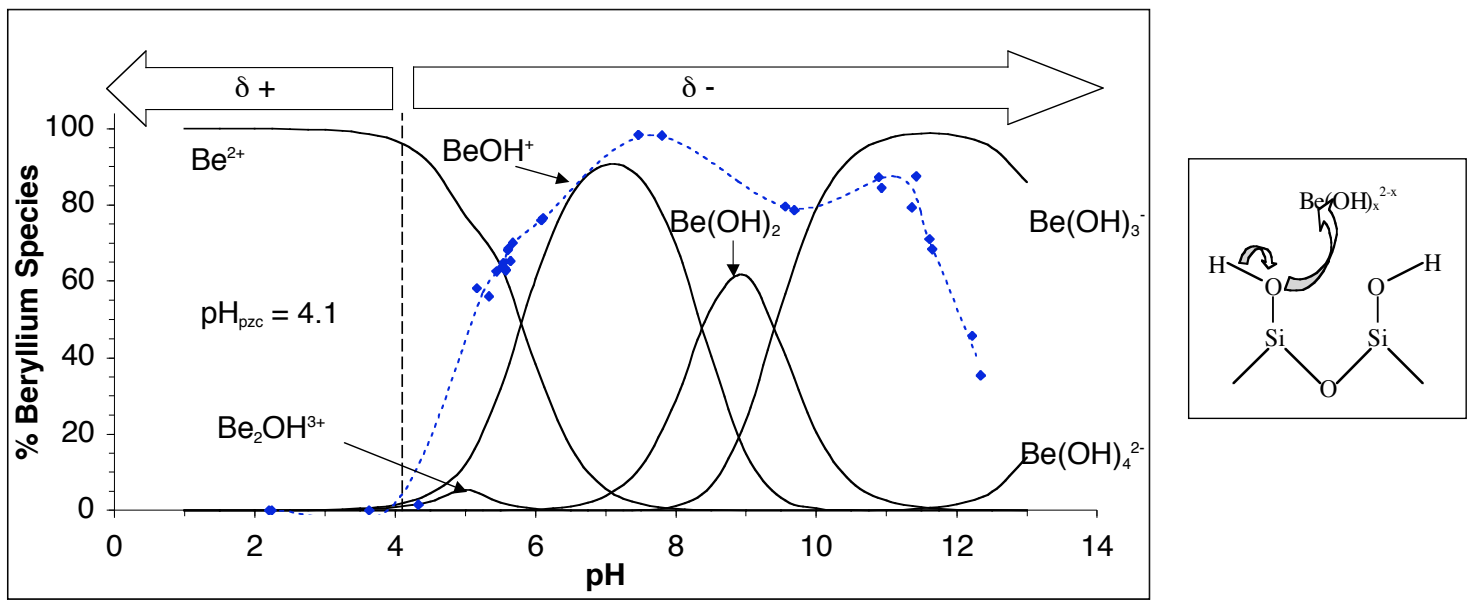

Figure 4-4. Effect of pH on beryllium soption onto aerogel/GAC material. (a) Speciation overlaying experimental sorption with increasing $\mathrm{pH}$. (b) Proposed sorption mechanism. 


\subsection{Summary}

In summary, the characterization of beryllium sorption onto aerogel/GAC material presented in this work suggests that beryllium shows an affinity for aerogel/GAC material over a moderately wide range of $\mathrm{pH}$ conditions (optimal in a fairly neutral range) and can be described adequately by Freundlich sorption theory. Sorption kinetics show fairly slow equilibration times, possibly due to the chemical nature of the bonds formed. The work also provides a baseline to compare functionalized aerogel/GAC composites designed specifically to bind beryllium with a high efficiency for use in workplace and environmental cleanup, or beryllium recovery from waste-streams. When placed in flowthrough columns, beryllium can be efficiently removed utilizing the sorption parameters described herein, and then subsequently desorbed by acidification. Regenerated GACaerogel material could then be reused. Furthermore, the functionalization of the aerogel to include chelators specific for beryllium could increase the effectiveness and selectivity of binding.

\subsection{References}

(1) U.S. Department of Health and Human Services, Public Health Service, National Toxicology Program, Pursuant to Section 301(b) (4) of the Public Health Service Act as Amended by Section 262, PL 95-622 USDHHS - http://ehp.niehs.nih.gov/roc/toc10.html 2002 (accessed Jan 2005).

(2) Reeves, A. L. Experimental Pathology. In Beryllium: Biomedical and Environmental Aspects (Rossman, M. D., Preuss, O. P. and Powers, M. B.) Lippincott, Williams and Wilkins, Philiadelphia, P.A. 1991.

(3) Cunningham, L. D. Beryllium Recycling in the United States in 2000, Joint US Department of Interior/ US Geological Survey Report 03-282, 2003. Reston VA.

(4) Morrell, D. M., Miller, J. R. and Allen, D. F. The Rocky Flats Environmental Technology Site Beryllium Characterization Project. In Proceedings of International Conference on Decommissioning and Decontamination and on Nuclear and Hazardous Waste Management, American Nuclear Society. La Grange Park, IL. 1998, 2, 1165-1171.

(5) United States Code of Federal Regulations (US CFR), Title 29, Labor, Part 1910, 1999. Occupational Safety and Health Standards, Subpart Z, Toxic and Hazardous Substances, Title 29, Volume 6, parts 1910.1000 onward. Washington DC.

(6) United States Code of Federal Regulations (US CFR), Title 10, Energy, Part 850, 2001. Chronic Beryllium Disease Prevention Program, Department of Energy, Title 10, Volume 4 Parts 850 onward. Washington DC.

(7) Taylor T. P., Ding, M., Ehler, D. S., Foreman, T. M., Kaszuba, J. P. and Sauer, N. N., J. Environ. Sci. Health, 2003, A38, 439-469

(8) Environmental Protection Agency, List of Drinking Water Contaminants \& MCLs, http://www.epa.gov/safewater/mcl.html\#1 2004 (accessed Jan 2005).

(9) Al-Saleh, I., Al-Doush, I. The Science of the Total Environment, 1998, 216, 181-192.

(10) Environmental Protection Agency, National Primary Drinking Water Regulations - Technical Factsheet on: Beryllium. http://www.epa.gov/ogwdw000/dwh/t-ioc/berylliu.html 2002 (accessed Jan 2005). 
(11) Kusakabe, M., Ku, T. L., Southon, J. R., Liu, S., Vogel, J. S., Nelson, D. E., Nakaya, S., Cusimano, G. L., Earth and Planetary Science Letters 1991, 102 (3-4) 265-276.

(12) Hormann, P. K. Beryllium, in Handbook of Geochemistry; Wedepohl, K. H. Ed. Springer-Verlag, New York, 1969, 4D1-4O7.

(13) Brown, E. T., Edmond, J. M., Raisbeck, G. M., Bourles, D. L., Yiou, F. and Measures, C. I., Geochimica et Cosmochimica Acta, 1992, 56, 1607-1624.

(14) Kram, P., Hruska, J. and Driscoll, C. T., Water Air and Soil Pollution, 1998, 105,

(15) Shireman, J., Mayila, A. S., Bradley, C. K., Allen, M. S. Statistical analysis of the occurrence of beryllium in soils at naval air station Moffett Field, in Hydrocarbon Contaminated Soils. Kostechi, P. T., Calabrese, E. J., Bonazountas, M. Eds. ASP: Amherst, MA, 1995, vol 5, Ch 9, 93-121.

(16) United States Environmental Protection Agency (US EPA). Damage Cases and Environmental Releases from Mines and Mineral Processing Sites, RCRA. Washington DC, 1998.

(17) Rich, V., New Scientist 1999, 128, 1737, 19 and 128, 1743, 15.

(18) Hassler J. W. Activated Carbon: Industrial, Commercial, Environmental Chemical Publishing Co. Inc. New York, 1974 p3

(19) Ostrejko, R. von, British Patents 14224 (1900); 18040 (1900); German Patent 136,792 (1901).

(20) Santhy K. and Selvapathy, P., Separation Science and Technology 2004, 39, 14, 3331-3351.

(21) Das D, Gaur V, Verma N., Carbon, 2004, 42 (14): 2949-2962.

(22) Aerogel/GAC Composites for Adsorption of Contaminants. LLNL Document UCRL-WEB-146619, 2002.

(23) Guinness World Records, 2004, Least Dense Solid

http://www.guinnessworldrecords.com/index.asp?id=58445

(24) Coleman, S. J., Coronado, P. R., Maxwell, R. S. et al., Environmental Science and Technology, 2003, 37, 2286-2290.

(25) Reynolds, J. G., Coronado, P. R. and Hrubesh, L. W., J. Non-Crystallite Solids, 2001, 292, 127-137.

(26) Hrubesh, L. W., Coronado, P. R. and Satcher, J. H., J. Non-Crystalline Solids, 2001, 285, 328-332.

(27) Bae, E., Chah, S. and Yi, J. H., J. Colloid and Interface Science, 2000, 230, 367-376.,

(28) Ahmed, M. S. and Attia, Y. A., Applied Thermal Engineering, 1998, 18, 787-797.

(29) Coleman, S. J. Coronado, P. R. et al. Removal of Uranium and Hexavalent Chromium from Waters using Aerogel-Granular Activated Carbon Composites, Technical Information Exchange (TIE) Workshop, Oakland, CA, Nov 12 - Nov 12, 2002, LLNL-UCRL-JC-150753-ABS.

(30) Taylor, T. P., Le, Q. T. H., Ehler, D. S. and Sauer, N. N. Separation Sci. Technol. 2003, 38, 1141 1160.

(31) Sutton, M., Burastero, S. R., Mundy, C. and Quong, J., The Pharmacologist, 2002, 44, A174, 100.24. 
(32) Navratil, T., Geolines, 2000, 12, 18-33

(33) Sutton, M., Warwick, P., Hall, A. and Jones, C., J. Environ. Monit. 1999, 1, 177-182.

(34) Sutton, M. and Burastero, S. R. Chem. Res. Toxicol. 2003, 16, 1145-1154.

(35) Sutton, M., Warwick, P. and Hall, A., J. Environ. Monit. 2003, 5, 922-928.

(36) Kettrup, A., Ackermann, P. and Riepe, W., Z. Naturforsche, 1978, 33b, 183-189.

(37) Gruenewald, B. and Knoche, W., J. Chemical Society Dalton Transactions, 1978, 1221-1225.

(38) Evans, D. F., Wong, C. Y, J. Chemical Society Dalton Transactions, 1992, 2009-2012.

(39) Cecconi, F., Dominguez, S., Masciocchi, N., Mildollini, S., Sironi, A. and Vacca, A. Inorganic Chemistry, 2003, 42, 2350-2356.

(40) Inada, Y., Nakayama, Y. and Funahashi, S., J. Solution Chemistry, 2004, 33, 6/7, 847-862.

(41) Allison, J. D., Novo-Gradac, K. J. and Brown, D. S., MINTEQA2 ver.4. - A geochemical assessment model for environmental systems. Environmental Research Laboratory, Office of Research \& Development, United States Environmental Protection Agency, Athens, Georgia, 1998.

(42) Coronado, P. R., Reynolds, J. G. and Coleman, S. J. Composites for Removing Metals and Volatile Organic Compounds and Method Thereof, US Patent Application Serial number 10/285, 242, filed October 30, 2002. Coronado, P. R., Reynolds, J. G. and Coleman, S. J. Solid Materials for Removing Metals and Fabrication. International Patent Publication Number WO 2004/013050 A3, February 12, 2004.

(43) Rivera-Utrilla, J. and Sanchez-Polo, M. App. Cat. B. Environ. 2002, 39, 319-329.

(44) Karanfil, T. and Kilduff, J. E. Environ. Sci. Technol. 1999, 33, 3217-3224.

(45) Babic, B. M., Molonjic, S. K., Polovina, M. J and Kaludierovic, B. V. Carbon 1999, 37, 477-481.

(46) Arico, A. S., Antonucci, V. Minutoli, M., Giordano, N. Carbon 1989, 27, 337-347.

(47) Corapcioglu, M. O. and Huang, C. P. Carbon, 1987, 25, 569-578.

(48) Reed, B. E., Matsumoto, M. R. Separation Science and Technology, 1993, 28, 2179-2195.

(49) Menendez, J. A, Illan-Gomez, M. J. Leon y Leon, C. A. and Radovic, L. J. R., Carbon, 1995, 33, 1655-1657.

(50) Aldahan, A., Haiping, Ye and Possnert, G. Chemical Geology, 1999, 156, 209-229.

(51) Korkisch, J. and Sorio, A., Analytical Chimica Acta, 1976, 82, 311-320.

(52) Harju, L. and Krook, T., Talanta, 1995, 42,3,431-436.

(53) Moskvin, L. N., Drogobuzhskaya, S. V. and Moskvin, A. L., Journal of Analytical Chemistry, 1999, $54,3,240-243$.

(54) Freundlich, H. Z. Phys. Chem. 1906, 57, 385.

(55) Okutani, T., Tsuruta. Y. and Sakuragawa, A., Analytical Chemistry, 1993, 65, 1273-1276. 
(56) Ramesh, A., Rama Mohan, K., Seshaiah, K. and Venkateswarlu Choudary, N. Separation Science Technology, 2002, 37, 1123-1134 


\section{5}

\section{Uranium(VI) Speciation and Solubility in Simulated Elemental Human Biological Fluids}




\section{Uranium(VI) Speciation and Solubility in Simulated Elemental Human Biological Fluids}

\subsection{Introduction}

Uranium has been widely used in applications beyond the nuclear industry. For example, the manufacture of Fiestaware tableware, popular until the 1960's, included uranium oxides resulting in a decorative orange color. The high density of depleted uranium (DU, $19.0 \mathrm{~g} / \mathrm{cm}^{3}$, almost twice that of lead at $11.3 \mathrm{~g} / \mathrm{cm}^{3}$ ) is exploited in balancing cargo weights in transport aircraft and ships, radiation shielding in shipping containers for radiopharmaceuticals, gyroscopes of inertial guidance systems and in armor-piercing ammunition and armor plating. The human body naturally contains approximately $90 \mu \mathrm{g}$ of uranium (1) and overexposure to uranium results in both chemical and radiological toxicity.

The radiological component of uranium toxicity is largely dependent on the isotopic proportions of the exposure. Higher proportions of enriched uranium result in radiological toxicity. Most uranium isotopes decay by emission of alpha particles that have a large amount of energy to dissipate upon interaction with nearby biological material. Therefore, uranium radiological toxicity is caused by internal exposure through inhalation, ingestion or subcutaneous penetration. Uranium is known to be a bone-seeker and readily replaces calcium in the bone structure, which can elevate long-term internal radiological exposure, slow the dissolution/exchange with interstitial fluid and create the potential for bone cancer (2).

The chemical toxicity of overexposure is dictated by the chemical nature the uranium exposure, which in turn affects uranium absorption, distribution, deposition, and excretion. For example, Scott (3) has described $\mathrm{UF}_{6}, \mathrm{UO}_{3}$, uranium sulfates and carbonates as highly transportable from the lungs, whereas $\mathrm{UO}_{2}, \mathrm{U}_{3} \mathrm{O}_{8}$, uranium carbides and hydrides are only slightly transportable. Accidental exposures to soluble uranium are reported in the literature (4), of which many cases involved the inhalation of gaseous $\mathrm{UF}_{6}$ leaking from uranium enrichment systems. Chemical toxicity primarily affects damage to the proximal tubule of the kidney, resulting in nephritis and proteinuria (5). The mechanism of nephrotoxicity may involve binding of uranium to the brush border membrane in the distal portion of the proximal tubules (5). The degree of renal damage is dependent upon the level of intake, and if overexposure is limited, kidneys recovery generally can take several weeks provided there is no subsequent re-exposure. High levels of exposure cause high urinary uranium levels, the greatest renal damage (as evidenced by albuminuria, red cells and casts in the urinary sediment, and elevated blood urea nitrogens) and death from renal failure (2). Research experience with chronic lowlevel exposure has been less conclusive. While earlier researchers (3) reported virtually no nephrotoxicity with chronic low-level exposures, a later study of uranium mill workers suggests that long term low exposures can result in $\mathrm{B}_{2}$ microglobinuria and amino aciduria (6), which is consistent with low grade renal toxicity involving the proximal tubule. However, there is a paucity of research on long-term health effects of low-level chronic exposure. 
Recently, the use of DU ammunition and possible links between the exposure of military personnel to DU fine particles and Gulf War Syndrome (2,7-9) has generated much interest in the medical and environmental fate of DU. What is clear is that personnel exposed to DU shrapnel do exhibit elevated urinary uranium concentrations $(10,11)$. However, there is much debate over the association of DU exposure and Gulf War Syndrome, especially when multiple potential environmental exposures (chemical / biological agents and vaccines) are also taken into account (12,13). Bleise (14) reported that with the exception of the crews of military vehicles having been hit by DU penetrators, no body burdens above the range of values for natural uranium have been found and that no observable health effects are expected.

Hexavalent uranyl compounds are generally slightly more soluble than the tetravalent uranium analogs and the aqueous uranyl complexes are thermodynamically more stable in aerobic environments. The uranyl ion is also amphoteric, i.e. it reacts with both acids and bases to form a mixture of positively and negatively charged species. The current treatment for uranium over exposure is outlined by REAC/TS (Radiation Emergency Assistance Center/Training Site) provided by Oak Ridge National Laboratory and suggests that patients be given an infusion of $250 \mathrm{~mL}$ of a $1.4 \%$ sodium bicarbonate solution $(15,16)$, increasing the $\mathrm{pH}$ of urine and consequently enhancing uranium excretion. At neutral and higher $\mathrm{pH}$, exceptionally stable uranyl carbonate complexes are formed, $\mathrm{UO}_{2}\left(\mathrm{CO}_{3}\right)_{2}{ }^{-2}$ and $\mathrm{UO}_{2}\left(\mathrm{CO}_{3}\right)_{3}^{-4}$. In 1949, it seemed somewhat doubtful that a more effective uranium poisoning treatment than bicarbonate would be found (17). In 2000, Stradling (18) reports that since bicarbonate administration is not effective for uranium dust and aerosol exposure, development of chelators remains an outstanding problem. Bicarbonate treatment is by no means specific for uranium, and several researchers have examined the role of chelation therapy as a treatment for reducing uranium body burden (19-22). New generations of chelators can be designed to be both effective and selective in removing toxic metals from the body while leaving other essential metals untouched $(23,24)$. Over the last decade, considerable progress has been made in evaluating new treatment regimes and chelators for some actinides, but research to find new methods of uranium decorporation should be expedited through collaborations between clinicians and researchers (25). In order to develop an effective uranium chelator, it is also crucial to first understand the chemistry and distribution of uranium in body fluids. It is important to understand both the chemical environments uranium will encounter during and after exposure, and the chemical effects that might alter the stability and efficiency of uranium chelation and excretion. An overview of the contribution of chemical speciation to internal dosimetry is given by Paquet (26), who concludes that computer speciation modeling can be used to provide a first estimate of species distribution at equilibrium and that metal speciation in regard to human internal dosimetry will remain a challenge for the coming decades. Furthermore, previous models of uranium speciation in fluids using chemical thermodynamics $(27,28)$ fall short of a complete assessment of uranium chemical interactions using thorough elemental fluid compositions, considering only a portion of the potential elemental interactions. Comprehensive chemical thermodynamic models have been used to study the environmental behavior of uranium(VI) in regard to nuclear waste disposal, and serve to provide a better understanding of uranium chemistry $(29,30)$. 
This paper describes the speciation of uranium(VI) in a number of simulated elemental human body fluids by using chemical thermodynamics speciation and solubility modeling using methods previously described to study beryllium speciation in body fluids (31). The work is of importance to the understanding of uranium metabolism and toxicology. Modeling can provide an important insight into uranium chemistry in biological fluids and consequently aid in the development of chelation techniques or other methods to treat overexposures. Furthermore, if results can be applied to predicted urinary excretion of uranium, they may have application to biological monitoring for uranium exposure.

\subsection{Materials and Methods}

The elemental composition of human body fluids (intracellular fluid, interstitial fluid, plasma water, saliva, sweat, urine, bile, gastric juice and pancreatic fluid) used in this study is previously described (31). Interstitial fluid and airway surface fluid (ASF) concentrations are in $\mathrm{mM}$ range and not $\mathrm{nM}$ as stated. For ASF, only the following cases were investigated: (a) normal ASF, (b) ASF collected after treatment with an anticholinergic therapy, (c) ASF collected after treatment with benzodiazepine, (d) ASF while in a hypersecretory state.

Model input files were generated using the PRODEFA2 code (32) for each of the body fluids. The thermodynamic data in the THERMO.DBS database (32) that accompanies the MINTEQA2v4 model was compared for compatibility and updated with critically reviewed chemical thermodynamics data from the NIST database $(33,34)$ and Nuclear Energy Agency (NEA) thermodynamic uranium dataset (35). Two concentrations of uranium were used to simulate the low uranium particle solubility in the biological environment $(1 \mu \mathrm{M}, 238 \mu \mathrm{g} / \mathrm{L})$ and acute poisoning $(1 \mathrm{mM}, 238 \mathrm{mg} / \mathrm{L})$, and the reaction temperature was set to $37{ }^{\circ} \mathrm{C}$. For comparison, the estimated typical uranium lung burden in a Gulf War DU-positive veteran is $340 \mu \mathrm{g}$ (36) while an occupationally exposed lung deposition is $3.1 \mathrm{mg}$ (37). In cases where fluids are normally in contact with air, the system was equilibrated with atmospheric $\mathrm{CO}_{2}$ gas $(0.03 \%)$ to maintain carbonate concentrations especially in the cases where carbon was not detailed in the elemental composition. For a simulated fluid model, any element with a concentration less than 5\% of the total lower uranium concentration was removed from the input dataset. Once each model was programmed with element concentrations and $\mathrm{pH}$, the MINTEQA2 code was run and the uranium speciation data was transferred to Microsoft Excel for data analysis. The effect of $\mathrm{pH}$ on the uranium speciation was investigated for each fluid, and speciation studied more rigorously at the actual biological $\mathrm{pH}$ of each fluid. For comparison, speciation models of uranium in water $\left(\mathrm{CO}_{2}\right.$ free $)$ and air/water systems were also performed.

\subsection{Results and Discussion}

The results obtained by chemical thermodynamic modeling allow examination of the aqueous chemistry of uranium in regard to the elemental constituents of the biological fluids. The results show how the soluble uranium is chemically distributed after reacting with other constituents of the elemental biological fluids. For reference, the speciation of 
low and high uranium in $\mathrm{CO}_{2}$-free water at $37^{\circ} \mathrm{C}$ is shown in Figure 5-1. At lower concentrations of uranium, hydrolysis starts at approximately $\mathrm{pH} 3$ and is dominated by the formation of monomeric hydroxides such as $\mathrm{UO}_{2} \mathrm{OH}^{+}$, aqueous $\mathrm{UO}_{2}(\mathrm{OH})_{2}$ and $\mathrm{UO}_{2}(\mathrm{OH})_{3}{ }^{-}$. At higher uranium concentration, dimers $\left[\left(\mathrm{UO}_{2}\right)_{2}(\mathrm{OH})_{2}{ }^{+2}\right]$, trimers $\left[\left(\mathrm{UO}_{2}\right)_{3}(\mathrm{OH})_{5}^{+}\right]$and even tetramers $\left[\left(\mathrm{UO}_{2}\right)_{4}(\mathrm{OH})_{7}^{+}\right]$are formed in addition to the monomeric hydroxides. However, the speciation diagrams of the dilute and concentrated uranium systems at biological $\mathrm{pH}$ are similar and mainly consist of $\mathrm{UO}_{2} \mathrm{OH}^{+}$. In the presence of $\mathrm{CO}_{2}$, uranium carbonate complexes begin to form at $\mathrm{pH} 7$ (Figure 5-2), and compete with hydrolysis to form the dominant species. Of note is the presence of a mixed hydroxycarbonate species, $\left(\mathrm{UO}_{2}\right)_{2}(\mathrm{OH})_{3} \mathrm{CO}_{3}^{-}$, which formed at $\mathrm{pH}$ 7-8. The chemistry of uranium in both $\mathrm{H}_{2} \mathrm{O}$ and $\mathrm{HCO}_{3}$ systems is rather well defined, especially in environmental chemistry, and is summarized by several researchers (38-43). The thermodynamic data chosen for the models included in this work are critically reviewed (35) and models are therefore consistent with the NEA consensus of uranium chemistry in aqueous (and bicarbonate) systems.

The uranium speciation, solubility and precipitation in both dilute and concentrated solutions are shown in Table 5-1 for the important $\mathrm{pH}$ ranges for each biological fluid. In cases where speciation varies within the $\mathrm{pH}$ range, a speciation diagram is presented. 
(a)

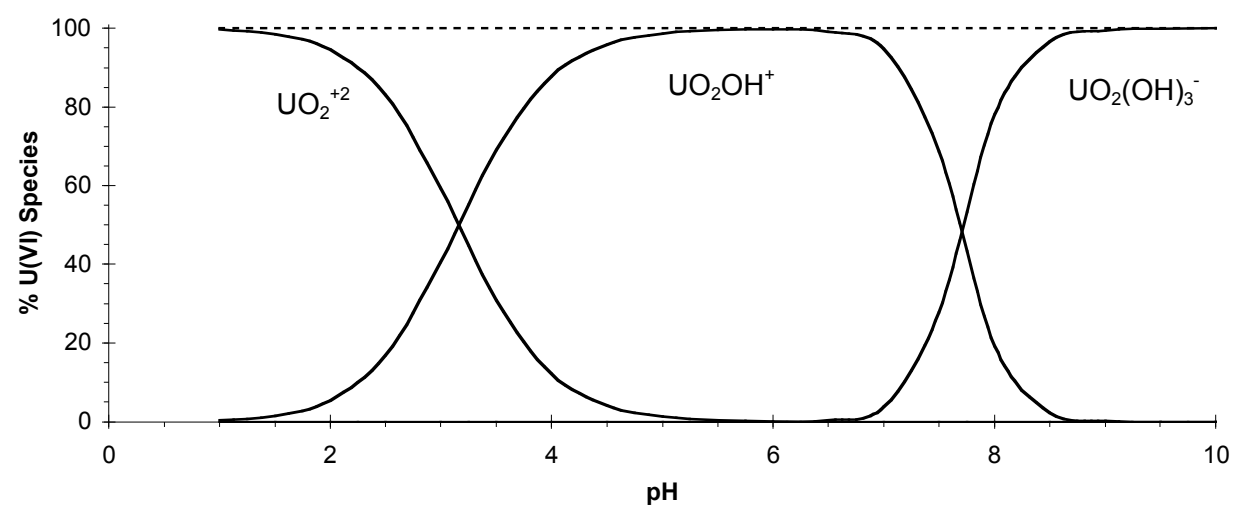

(b)

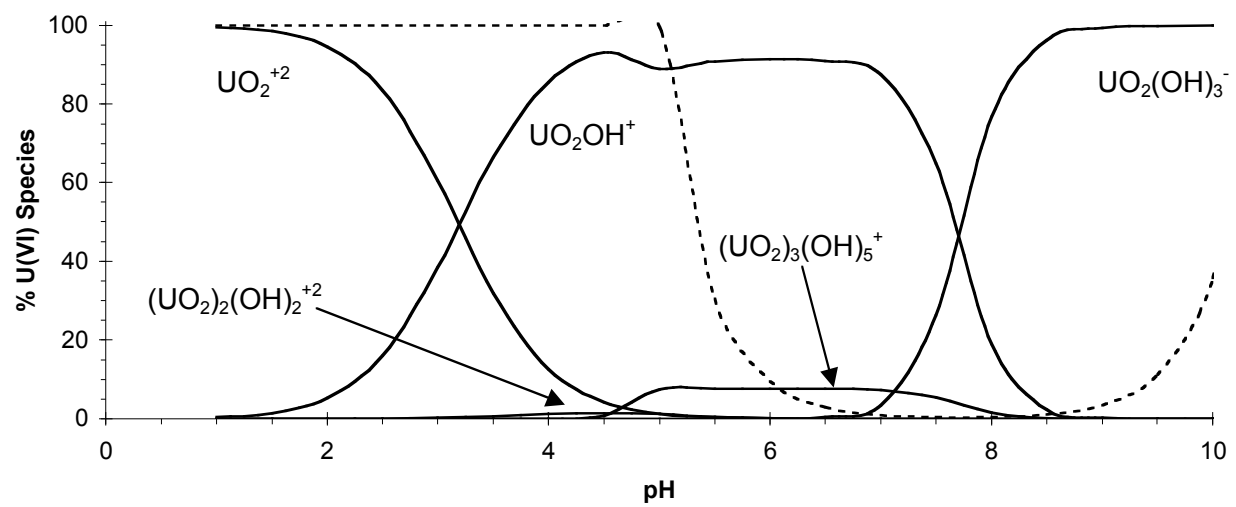

Figure 5-1. Uranium speciation and solubility with varying $\mathrm{pH}$ in the $\mathrm{U}(\mathrm{VI})-\mathrm{H}_{2} \mathrm{O}$ system at $[U]=(a) 1 \mu M$ and (b) $1 \mathrm{mM}$. A dashed curved line depicts solubility 
(a)

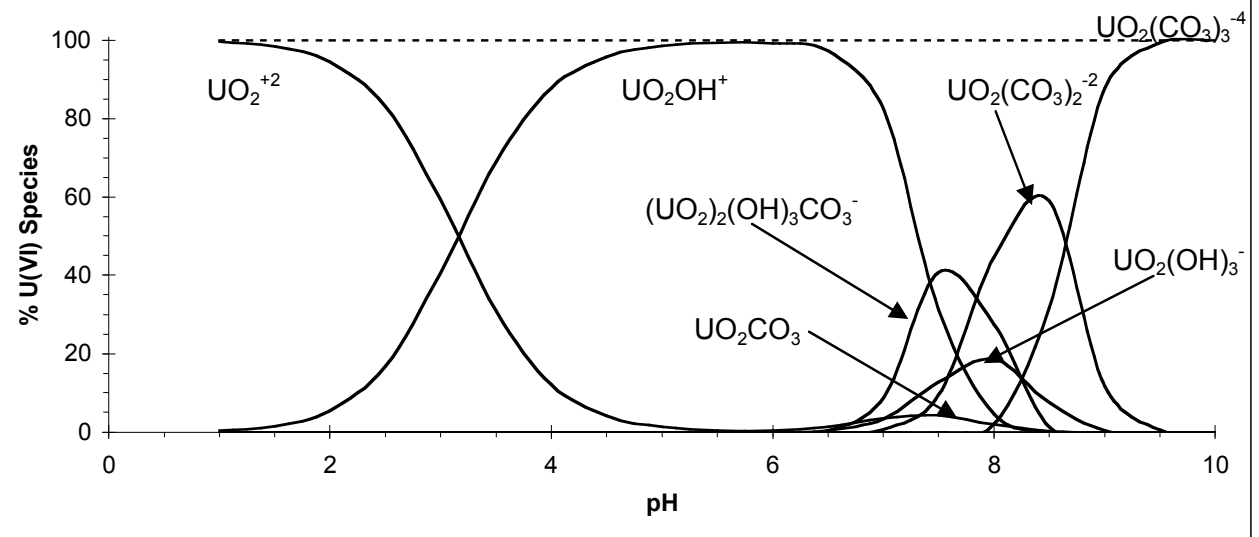

(b)

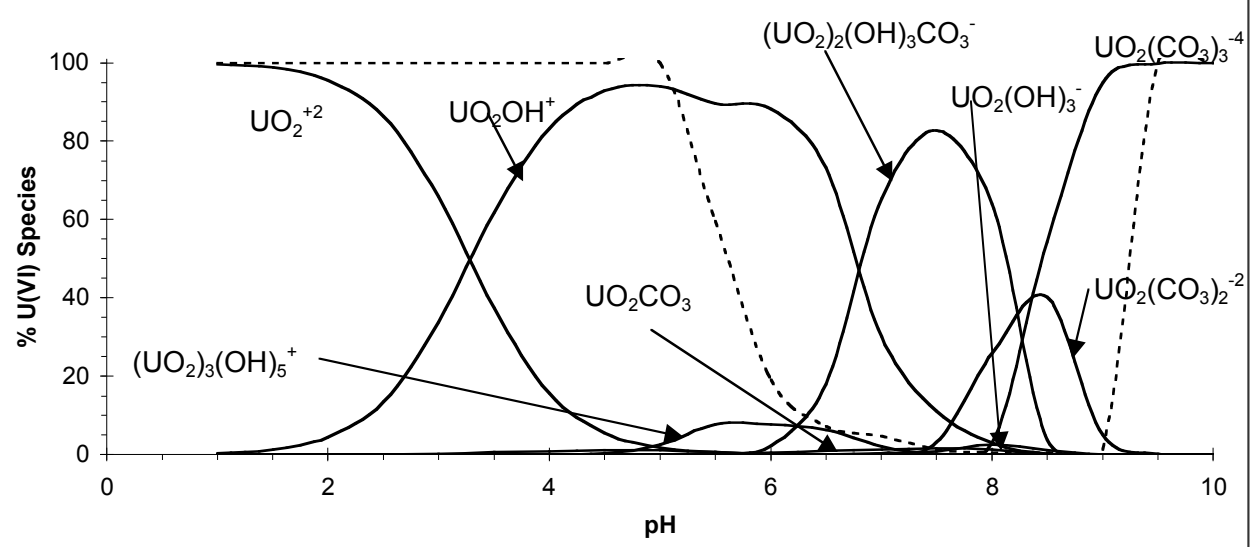

Figure 5-2. Uranium speciation and solubility with varying $\mathrm{pH}$ in the $\mathrm{U}(\mathrm{VI})-\mathrm{H}_{2} \mathrm{O}-\mathrm{CO}_{3}$ system at $[U]=(a) 1 \mu M$ and (b) $1 \mathrm{mM}$. A dashed curved line depicts solubility. 


\begin{tabular}{|c|c|c|c|c|c|c|c|}
\hline \begin{tabular}{|l|} 
Biological \\
Fluid \\
\end{tabular} & pH & $\begin{array}{l}\text { U(VI) Speciation } \\
\text { Solutions }\end{array}$ & Dilute & $\begin{array}{l}\text { U(VI) Speciation } \\
\text { Concentrated So }\end{array}$ & & U(VI) Solubility & $\begin{array}{l}\text { Solubility Limiting } \\
\text { Phase }\end{array}$ \\
\hline Intracellular & $\begin{array}{l}6 \\
7.4 \\
\end{array}$ & $\begin{array}{l}\mathrm{UO}_{2}\left(\mathrm{HPO}_{4}\right)_{2}^{-2} \\
\mathrm{UO}_{2}\left(\mathrm{HPO}_{4}\right)_{2}^{-2}\end{array}$ & $\begin{array}{l}100 \% \\
100 \% \\
\end{array}$ & $\begin{array}{l}\mathrm{UO}_{2}\left(\mathrm{HPO}_{4}\right)_{2}^{-2} \\
\mathrm{UO}_{2}\left(\mathrm{HPO}_{4}\right)_{2}^{-2}\end{array}$ & $\begin{array}{l}100 \% \\
100 \% \\
\end{array}$ & $\begin{array}{l}12.8 \mathrm{mM} \\
4.9 \mathrm{mM}\end{array}$ & $\begin{array}{l}\mathrm{K}_{2}\left(\mathrm{UO}_{2}\right)_{2}\left(\mathrm{PO}_{4}\right)_{2} \cdot 6 \mathrm{H}_{2} \mathrm{O} \\
\mathrm{K}_{2}\left(\mathrm{UO}_{2}\right)_{2}\left(\mathrm{PO}_{4}\right)_{2} \cdot 6 \mathrm{H}_{2} \mathrm{O}\end{array}$ \\
\hline Interstitial & 7.4 & $\begin{array}{l}\mathrm{UO}_{2}\left(\mathrm{CO}_{3}\right)_{3}^{-4} \\
\mathrm{UO}_{2}\left(\mathrm{CO}_{3}\right)_{2}^{-2}\end{array}$ & $\begin{array}{l}92 \% \\
8 \%\end{array}$ & $\begin{array}{l}\mathrm{UO}_{2}\left(\mathrm{CO}_{3}\right)_{3}^{-4} \\
\mathrm{UO}_{2}\left(\mathrm{CO}_{3}\right)_{2}^{-2}\end{array}$ & $\begin{array}{l}92 \% \\
8 \%\end{array}$ & $0.93 \mathrm{mM}$ & $\mathrm{Na}_{2}\left(\mathrm{UO}_{2}\right)_{2}\left(\mathrm{PO}_{4}\right)_{2} \cdot 8 \mathrm{H}_{2} \mathrm{O}$ \\
\hline Plasma & 7.4 & $\begin{array}{l}\mathrm{UO}_{2}\left(\mathrm{CO}_{3}\right)_{3}^{-4} \\
\mathrm{UO}_{2}\left(\mathrm{CO}_{3}\right)_{2}^{-2}\end{array}$ & $\begin{array}{l}91 \% \\
8 \% \\
\end{array}$ & $\begin{array}{l}\mathrm{UO}_{2}\left(\mathrm{CO}_{3}\right)_{3}^{-4} \\
\mathrm{UO}_{2}\left(\mathrm{CO}_{3}\right)_{2}^{-2} \\
\end{array}$ & $\begin{array}{l}91 \% \\
8 \% \\
\end{array}$ & $0.91 \mathrm{mM}$ & $\mathrm{Na}_{2}\left(\mathrm{UO}_{2}\right)_{2}\left(\mathrm{PO}_{4}\right)_{2} \cdot 8 \mathrm{H}_{2} \mathrm{O}$ \\
\hline Saliva & 6 & $\begin{array}{l}\mathrm{UO}_{2}(\mathrm{OH})_{2} \mathrm{aq} \\
\left(\mathrm{UO}_{2}\right)_{2}(\mathrm{OH})_{3} \mathrm{CO}_{3}^{-} \\
\mathrm{UO}_{2}(\mathrm{OH})_{3}^{-} \\
\mathrm{UO}_{2} \mathrm{CO}_{3} \mathrm{aq}\end{array}$ & $\begin{array}{l}81 \% \\
7 \% \\
5 \% \\
4 \%\end{array}$ & $\begin{array}{l}\left(\mathrm{UO}_{2}\right)_{3}(\mathrm{OH})_{5}^{+} \\
\mathrm{UO}_{2}(\mathrm{OH})_{2} \mathrm{aq} \\
\left(\mathrm{UO}_{2}\right)_{4}(\mathrm{OH})_{7}^{+} \\
\left(\mathrm{UO}_{2}\right)_{2}\left(\mathrm{OH}_{3}\right) \mathrm{CO}_{3}^{-} \\
\mathrm{UO}_{2} \mathrm{CO}_{3} \mathrm{aq} \\
\mathrm{UO}_{2}(\mathrm{OH})_{2} \mathrm{aq} \\
\left(\mathrm{UO}_{2}\right)_{2}(\mathrm{OH})_{3} \mathrm{CO}_{3}^{-} \\
\mathrm{UO}_{2}(\mathrm{OH})_{3}^{-} \\
\mathrm{UO}_{2} \mathrm{CO}_{3} \mathrm{aq}\end{array}$ & $\begin{array}{l}58 \% \\
24 \% \\
5 \% \\
5 \% \\
3 \% \\
73 \% \\
16 \% \\
4 \% \\
4 \%\end{array}$ & $0.44 \mu \mathrm{M}$ & $\mathrm{UO}_{2}(\mathrm{OH})_{2}$ \\
\hline Sweat & 7.5 & $\begin{array}{l}\mathrm{UO}_{2}(\mathrm{OH})_{2} \mathrm{aq} \\
\left(\mathrm{UO}_{2}\right)_{2}(\mathrm{OH})_{3} \mathrm{CO}_{3}^{-} \\
\mathrm{UO}_{2}(\mathrm{OH})_{3}^{-}(9 \%) \\
\mathrm{UO}_{2}\left(\mathrm{CO}_{3}\right)_{2}^{-2}\end{array}$ & $\begin{array}{l}58 \% \\
22 \% \\
9 \% \\
7 \%\end{array}$ & $\begin{array}{l}\mathrm{UO}_{2}^{+2} \\
\left(\mathrm{UO}_{2}\right)_{2}(\mathrm{OH})_{2}^{+2} \\
\left(\mathrm{UO}_{2}\right)_{3}(\mathrm{OH})_{5}^{+} \\
\left(\mathrm{UO}_{2}\right)_{2}(\mathrm{OH})_{3}^{+} \\
\mathrm{UO}_{2} \mathrm{OH}^{+} \\
\left(\mathrm{UO}_{2}\right)_{2}(\mathrm{OH})_{3} \mathrm{CO}_{3}^{-} \\
\mathrm{UO}_{2}(\mathrm{OH})_{2} \text { aq }\end{array}$ & $\begin{array}{l}41 \% \\
23 \% \\
21 \% \\
9 \% \\
4 \% \\
82 \% \\
12 \%\end{array}$ & $4.9 \mathrm{mM}$ & $\mathrm{CaUO}_{4} / \mathrm{UO}_{2}(\mathrm{OH})_{2}$ \\
\hline Pancreatic & 8.3 & $\begin{array}{l}\mathrm{UO}_{2}\left(\mathrm{CO}_{3}\right)_{2}^{-2} \\
\mathrm{UO}_{2}\left(\mathrm{CO}_{3}\right)_{3}^{-4} \\
\mathrm{UO}_{2}(\mathrm{OH})_{2} \mathrm{aq} \\
\mathrm{UO}_{2}(\mathrm{OH})_{3}^{-} \\
\left(\mathrm{UO}_{2}\right)_{2}(\mathrm{OH})_{3} \mathrm{CO}_{3}^{-} \\
\mathrm{UO}_{2}\left(\mathrm{CO}_{3}\right)_{3}^{-4} \\
\mathrm{UO}_{2}\left(\mathrm{CO}_{3}\right)_{2}^{-2} \\
\mathrm{UO}_{2}(\mathrm{OH})_{2}{ }^{-2} \\
\mathrm{UO}_{2}(\mathrm{OH})_{3}^{-}\end{array}$ & $\begin{array}{l}41 \% \\
33 \% \\
12 \% \\
8 \% \\
4 \% \\
63 \% \\
23 \% \\
5 \% \\
4 \% \\
\end{array}$ & $\begin{array}{l}\left(\mathrm{UO}_{2}\right)_{2}(\mathrm{OH})_{3} \mathrm{CO}_{3}^{-} \\
\mathrm{UO}_{2}\left(\mathrm{CO}_{3}\right)_{2}^{-2} \\
\mathrm{UO}_{2}\left(\mathrm{CO}_{3}\right)_{3}^{-4} \\
\mathrm{UO}_{2}(\mathrm{OH})_{2} \mathrm{aq} \\
\\
\mathrm{UO}_{2}\left(\mathrm{CO}_{3}\right)_{3}^{-4} \\
\left(\mathrm{UO}_{2}\right)_{2}(\mathrm{OH})_{3} \mathrm{CO}_{3}^{-} \\
\mathrm{UO}_{2}\left(\mathrm{CO}_{3}\right)_{2}^{-2}\end{array}$ & $\begin{array}{l}78 \% \\
9 \% \\
8 \% \\
3 \% \\
\\
52 \% \\
36 \% \\
9 \%\end{array}$ & $0.35 \mathrm{mM}$ & $\mathrm{UO}_{2}(\mathrm{OH})_{2}$ \\
\hline Bile & 7.8 & $\begin{array}{l}\mathrm{UO}_{2}\left(\mathrm{HPO}_{4}\right)_{2}^{-2} \\
\mathrm{UO}_{2}\left(\mathrm{CO}_{3}\right)_{2}^{-2} \\
\mathrm{UO}_{2}(\mathrm{OH})_{2} \mathrm{aq} \\
\mathrm{UO}_{2}(\mathrm{OH})_{3}^{-} \\
\mathrm{UO}_{2}\left(\mathrm{CO}_{3}\right)_{3}^{-4}\end{array}$ & $\begin{array}{l}34 \% \\
29 \% \\
22 \% \\
10 \% \\
3 \% \\
\end{array}$ & $\begin{array}{l}\left(\mathrm{UO}_{2}\right)_{2}(\mathrm{OH})_{3} \mathrm{CO}_{3}^{-} \\
\mathrm{UO}_{2}(\mathrm{OH})_{2} \\
\mathrm{UO}_{2}\left(\mathrm{CO}_{3}\right)_{2}^{-2}\end{array}$ & $\begin{array}{l}84 \% \\
7 \% \\
4 \%\end{array}$ & $0.44 \mu \mathrm{M}$ & $\mathrm{CaUO}_{4}$ \\
\hline $\begin{array}{l}\text { Gastric } \\
\text { Juice }\end{array}$ & 3.5 & $\begin{array}{l}\mathrm{UO}_{2}^{+2} \\
\mathrm{UO}_{2} \mathrm{H}_{2} \mathrm{PO}_{4}^{+} \\
\mathrm{UO}_{2} \mathrm{Cl}^{+} \\
\mathrm{UO}_{2}\left(\mathrm{HPO}_{4}\right)_{2}^{-2}\end{array}$ & $\begin{array}{l}88 \% \\
6 \% \\
5 \% \\
100 \%\end{array}$ & $\begin{array}{l}\mathrm{UO}_{2}^{+2} \\
\mathrm{UO}_{2} \mathrm{H}_{2} \mathrm{PO}_{4}^{+} \\
\mathrm{UO}_{2} \mathrm{Cl}^{+} \\
\mathrm{UO}_{2}\left(\mathrm{HPO}_{4}\right)_{2}^{-2} \\
\mathrm{UO}_{2}^{+2} \\
\mathrm{UO}_{2} \mathrm{~F}^{-}\end{array}$ & $\begin{array}{l}88 \% \\
6 \% \\
5 \% \\
94 \% \\
3 \% \\
2 \% \\
\end{array}$ & $0.44 \mathrm{mM}$ & $\mathrm{Na}_{2}\left(\mathrm{UO}_{2}\right)_{2}\left(\mathrm{PO}_{4}\right)_{2} \cdot 8 \mathrm{H}_{2} \mathrm{O}$ \\
\hline Urine & $\begin{array}{l}4.2 \\
8 \\
\end{array}$ & $\begin{array}{l}\mathrm{UO}_{2}\left(\mathrm{HPO}_{4}\right)_{2}^{-2} \\
\mathrm{UO}_{2}\left(\mathrm{HPO}_{4}\right)_{2}^{-2}\end{array}$ & $\begin{array}{l}100 \% \\
100 \% \\
\end{array}$ & $\begin{array}{l}\mathrm{UO}_{2}\left(\mathrm{HPO}_{4}\right)_{2}^{-2} \\
\mathrm{UO}_{2}\left(\mathrm{HPO}_{4}\right)_{2}^{-2}\end{array}$ & $\begin{array}{l}100 \% \\
100 \% \\
\end{array}$ & $\begin{array}{l}8.4 \mathrm{mM} \\
2.0 \mathrm{mM} \\
\end{array}$ & $\begin{array}{l}\mathrm{Na}_{2}\left(\mathrm{UO}_{2}\right)_{2}\left(\mathrm{PO}_{4}\right)_{2} \cdot 8 \mathrm{H}_{2} \mathrm{O} \\
\mathrm{Na}_{2}\left(\mathrm{UO}_{2}\right)_{2}\left(\mathrm{PO}_{4}\right)_{2} \cdot 8 \mathrm{H}_{2} \mathrm{O}\end{array}$ \\
\hline ASF & 7 & $\mathrm{UO}_{2}\left(\mathrm{HPO}_{4}\right)_{2}^{-2}$ & $100 \%$ & $\mathrm{UO}_{2}\left(\mathrm{HPO}_{4}\right)_{2}^{-2}$ & $100 \%$ & $3.0-9.1 \mathrm{mM}$ & $\mathrm{Na}_{2}\left(\mathrm{UO}_{2}\right)_{2}\left(\mathrm{PO}_{4}\right)_{2} \cdot 8 \mathrm{H}_{2} \mathrm{O}$ \\
\hline SLF & 7.4 & $\begin{array}{l}\mathrm{UO}_{2}\left(\mathrm{CO}_{3}\right)_{3}^{-4} \\
\mathrm{UO}_{2}\left(\mathrm{CO}_{3}\right)_{2}^{-2}\end{array}$ & $\begin{array}{l}92 \% \\
7 \% \\
\end{array}$ & $\begin{array}{l}\mathrm{UO}_{2}\left(\mathrm{CO}_{3}\right)_{3}^{-4} \\
\mathrm{UO}_{2}\left(\mathrm{CO}_{3}\right)_{2}^{-2}\end{array}$ & $\begin{array}{l}91 \% \\
8 \% \\
\end{array}$ & $2.3 \mathrm{mM}$ & $\begin{array}{l}\mathrm{Na}_{2}\left(\mathrm{UO}_{2}\right)_{2}\left(\mathrm{PO}_{4}\right)_{2} \cdot 8 \mathrm{H}_{2} \mathrm{O} \\
/ \mathrm{CaUO}_{4} / \mathrm{UO}_{2}(\mathrm{OH})_{2}\end{array}$ \\
\hline
\end{tabular}

Table 5-1. Summary of fluid pH, modeled uranium speciation, solubility and precipitation 


\subsubsection{Intracellular and Extracellular Fluids}

In simulated intracellular fluid, the major uranium species is $\mathrm{UO}_{2}\left(\mathrm{HPO}_{4}\right)_{2}^{-2}$ at both high and low uranium concentrations (Table 5-1). This is a consequence of the high concentration of phosphate ions in solution and the high affinity between uranyl and phosphate ions. Phosphate complexation also limits the formation of dimeric and trimeric uranium hydroxide species. $\mathrm{K}_{2}\left(\mathrm{UO}_{2}\right)_{2}\left(\mathrm{PO}_{4}\right)_{2} \cdot 6 \mathrm{H}_{2} \mathrm{O}$ (potassium-autunite) is predicted to form and therefore limits the uranium solubility. There are several reports of uranium phosphate needle-like precipitates within the cell $(44,45)$. Specifically, intracellular phosphate was subsequently bound to uranium as a precipitate within the cytoplasmic compartment (45). Even lower $\mathrm{pH}$ ranges may be encountered (perhaps as low as $\mathrm{pH} 4$ ) in the phagocytic lysosomal environments of macrophages within intracellular fluid. After phagocytosis of particulate matter, the macrophages are involved in the retention of these particles in the alveolar compartment (46). However, the phosphate complex remains the major species even at a lower $\mathrm{pH}$ until $\mathrm{pH} 1$ where the uncomplexed uranyl ion begins to dominate. At much higher $\mathrm{pH}$ values, carbonate complexation of uranium begins to dominate the speciation.

Carbonate species dominate much of the uranium chemistry in simulated interstitial fluid (Table 5-1, Figure 5-3). The phosphate concentration in interstitial fluid is lower than in that of intracellular fluid and so phosphate complexation is not sufficient to compete with the high carbonate affinity for uranyl ions at this neutral $\mathrm{pH}$. The solubility of uranium(VI) in interstitial fluid is limited by the formation of $\mathrm{Na}_{2}\left(\mathrm{UO}_{2}\right)_{2}\left(\mathrm{PO}_{4}\right)_{2} \cdot 8 \mathrm{H}_{2} \mathrm{O}$ (sodium-autunite). A similar case is true for uranyl ions in simulated plasma fluid (Table 5-1, Figure 5-3). Rothstein (47) reported a 40-fold increase in uranium solubility in plasma compared to water, caused by the formation of a soluble carbonate complex.

Uranium in plasma may enter the glomerulus and pass into the peritubular capillaries, or the tubular lumen where it is subsequently filtered into the urine or bound by the brushborder membranes of epithelial cell (5). Work by Chevari (48) has shown that in blood, uranium is bound as $50 \%$ carbonate and citrate complexes, $30 \%$ protein complexes (transferrin and albumin) and 20\% erythrocyte complexes. Scott (3) found that about $60 \%$ of uranium(VI) is carried as a soluble anionic complexes such as bicarbonate; the remainder bound to plasma protein (3) such as transferrin (5). However, as carbonate complexes are rapidly removed in glomerulus, the transferrin complex dissociates, and becomes less important in uranium speciation with respect to carbonate (5). Furthermore, brush-border membranes contain anionic sites that attract cationic uranyl speices $(5,49$ 51), which may in turn compete with calcium ions (52). Thus, there is equilibrium between uranium deposition on the cell surface and subsequent removal to lumen and urine (5).

Our results suggest that the concentration of uranium in elemental cellular fluids would be higher inside the cell than outside the cell. The results are consistent with those noted by Mirto (45) in that uranium enters the cell as a carbonate species and is then precipitated inside the cell as a phosphate mineral. The difference between the speciation of these three cellular fluids is largely due to the difference in phosphate and carbonate concentrations. At $\mathrm{pH}$ values less than the reference $\mathrm{pH}$ 7.4, phosphate complexation of 
uranium is clearly more important in both extracellular fluids. The results also have implications on the uranium solubility and speciation involved in kidney toxicity. The uranium $\mathrm{CL}_{50}$ (concentration leading to $50 \%$ cell death) of renal LLC-PK ${ }_{1}$ cells is 0.85 $0.90 \mathrm{mM}(45)$.

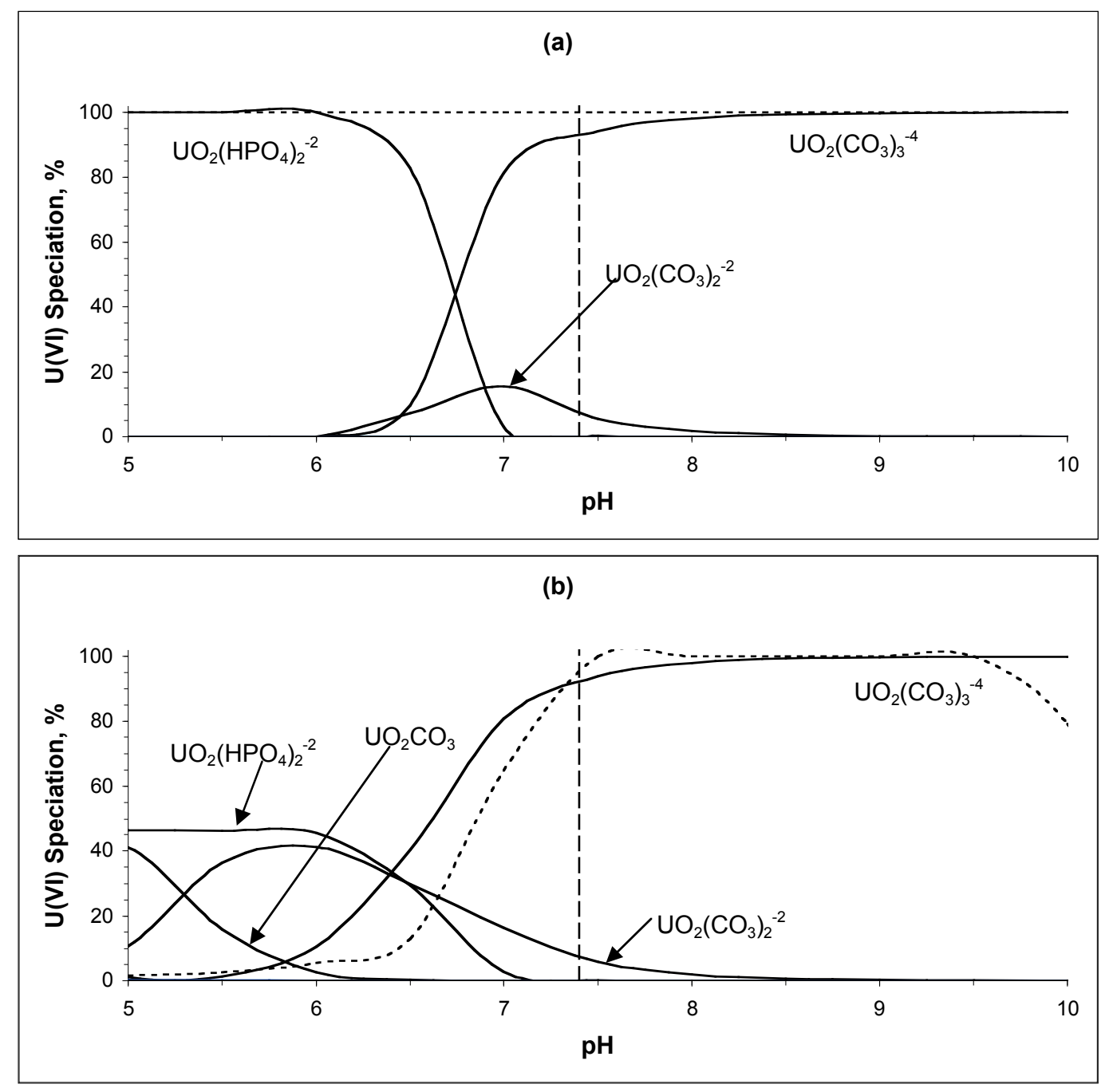

Figure 5-3. . Uranium speciation and solubility with varying $\mathrm{pH}$ in simulated interstitial and plasma fluids at $[U]=(a) 1 \mu M$ and (b) $1 \mathrm{mM}$. A dashed curved line depicts solubility. 


\subsubsection{Saliva}

The modeled speciation of uranium in simulated saliva is shown graphically in Figure 54. As can be seen in Table 5-1, the solubility of uranium(VI) at each pH boundary is limited by the formation of uranyl hydroxide $\left(\mathrm{UO}_{2}(\mathrm{OH})_{2}\right)$ which forms at $\mathrm{pH} 5-6.5$, generating a uranium solubility of $41.8 \mu \mathrm{M}$ at $\mathrm{pH}$ 6.0. Above $\mathrm{pH} 6.5 \mathrm{CaUO}_{4}$ (calcium uranate) begins to form. Within the reference $\mathrm{pH}$ limits for saliva, the mixed hydroxycarbonate species becomes more important with increasing $\mathrm{pH}$ until a maximum of $27 \%$ at $\mathrm{pH} 6.5$ where it begins to decrease with increasing amounts of aqueous $\mathrm{UO}_{2}(\mathrm{OH})_{2}$. By contrast, recent studies $(26,53)$ found that uranyl speciation in saliva was dominated by a mixture of phosphate and carbonate species at $\mathrm{pH}$ 7.5.

(a)

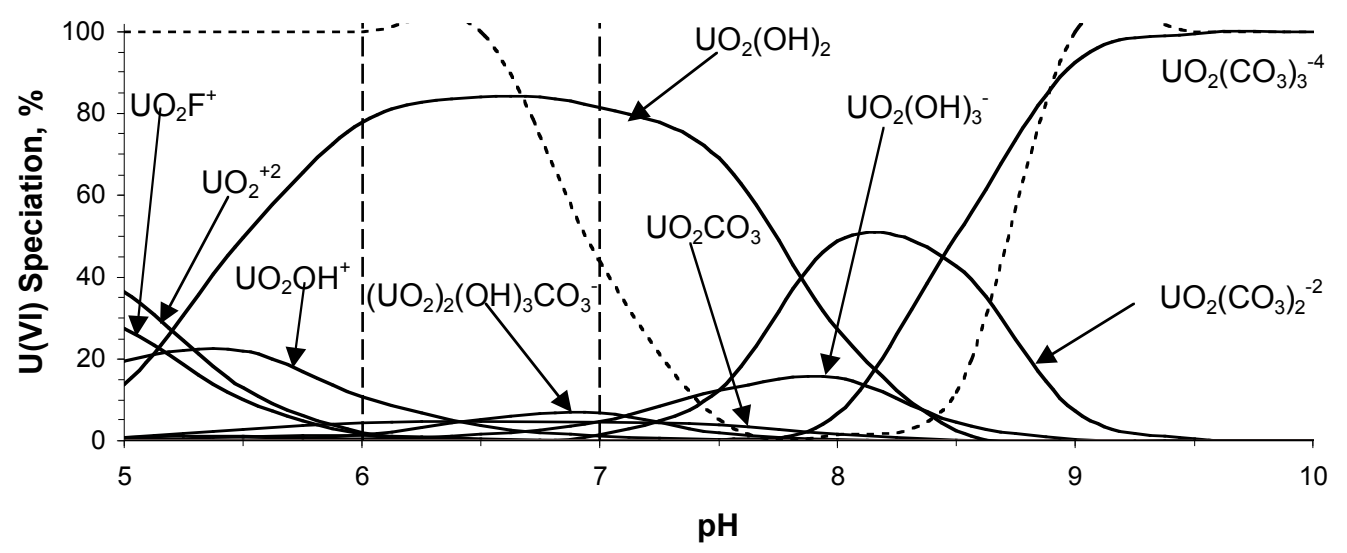

(b)

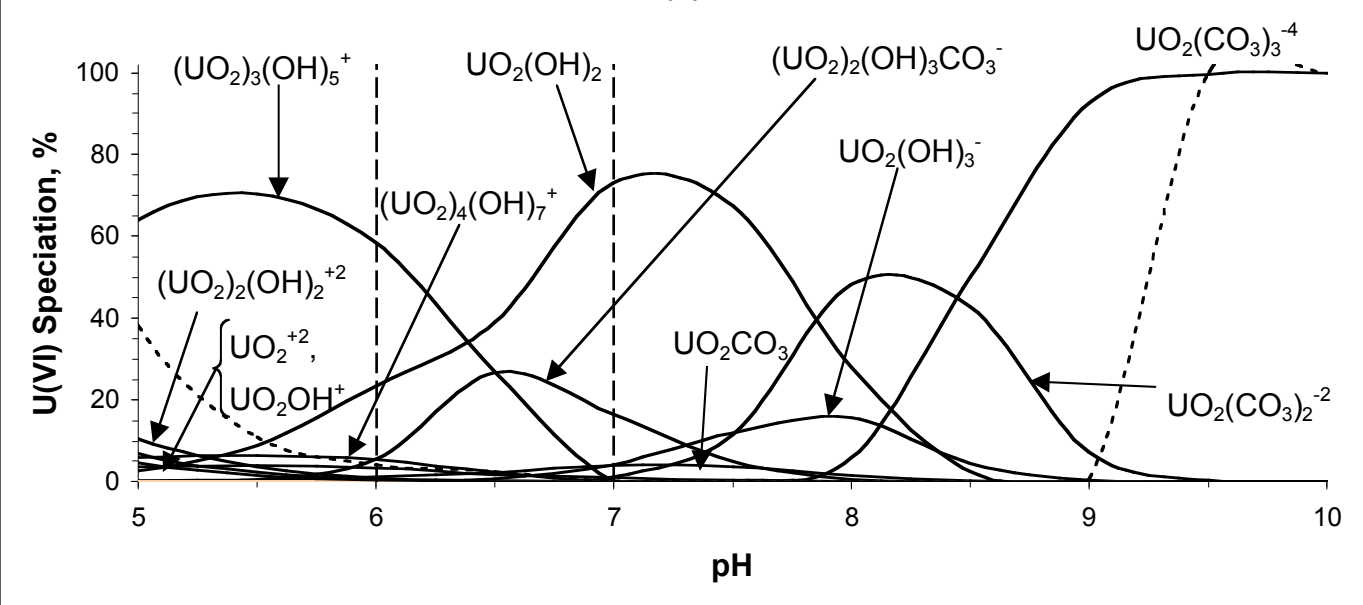

Figure 5-4. Uranium speciation and solubility with varying $\mathrm{pH}$ in simulated saliva at [U] $=(a) 1 \mu M$ and $(b) 1 m M$. A dashed curved line depicts solubility

In a study of uranium distribution in skeletal tissues, Hamilton (54) found uranium concentrations to be $7 \mathrm{ng} / \mathrm{g}$ for un-ashed teeth. Additionally, porcelain, prosthetic teeth historically contained uranium compounds to imitate the natural color, tone and fluorescent properties of human teeth. However, such prosthetic use is no longer 
approved in dental clinics. The average uranium concentrations in several Japanese denture brands are 3.6, 9.4 and $18 \mathrm{ppm}$, and $82 \mathrm{ppm}$ in a US brand (55). Furthermore, O'Riordan (56) found a mean uranium dental composition as high as $410 \mathrm{ppm}$ with a maximum uranium concentration of $1000 \mathrm{ppm}$. Clearly, the effect of saliva on the chemistry of uranium in teeth and dentures is relevant to this field.

\subsubsection{Sweat}

In simulated sweat, uranium at dilute concentrations (Table 5-1, Figure 5-5) is present in solution as a mixture of uranyl, hydroxide and carbonate ions. Clearly, with such wide reference $\mathrm{pH}$ limits $(4.2-7.5)$, the speciation and solubility of uranium(VI) changes greatly depending upon the exact $\mathrm{pH}$. At the lower $\mathrm{pH}$, uranium speciation is dominated by hydroxide and uncomplexed uranyl ions, while at high $\mathrm{pH}$, uranium speciation is dominated by carbonate complexation. The solubility of uranium in simulated sweat is limited by the formation of solid $\mathrm{UO}_{2}(\mathrm{OH})_{2}$ at lower $\mathrm{pH}$ values, and $\mathrm{CaUO}_{4}$ and $\mathrm{UO}_{2}(\mathrm{OH})_{2}$ precipitates at neutral to basic $\mathrm{pH}$ values.

(a)
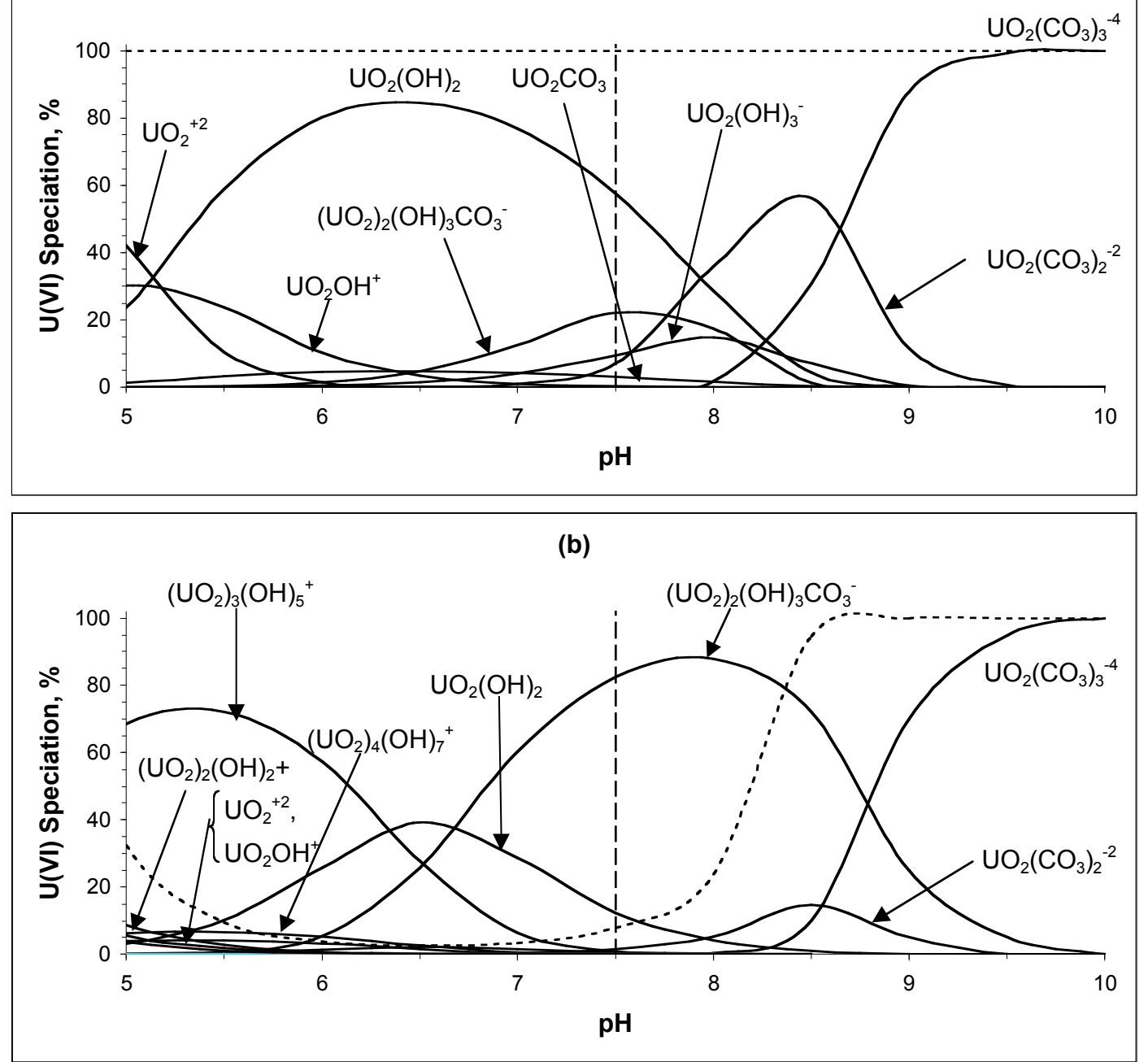

Figure 5-5. Uranium speciation and solubility with varying $p H$ in simulated sweat at [U] = (a) $1 \mu M$ and (b) $1 \mathrm{mM}$. A dashed curved line depicts solubility. 
There is evidence that uranium compounds can permeate through the skin and that surface area, contact time, concentration and chemical composition can greatly increase the absorption $(57,58)$. In a study of uranium worker exposure during the 1950's, it was found that the mean incidence of hand contamination of production and maintenance workers was $4.9 \%$ and $7.7 \%$ respectively, with a reported upper incidence value of $12.2 \%$ (59). Our model is relevant to industrial uranium workers and also military handlers of DU weapons, and highlights the likely uranium chemical species responsible for skin permeation and.

\subsubsection{Pancreatic Fluid and Bile}

The speciation of uranium(VI) in simulated pancreatic fluid (Table 5-1, Figure 5-6) is a good example of how the speciation of uranium can change dramatically with very small changes in $\mathrm{pH}$. Within $0.3 \mathrm{pH}$ units, the speciation varies between hydroxide and carbonate complexes. Similarly, the solubility of solid $\mathrm{UO}_{2}(\mathrm{OH})_{2}$ differs by a factor of two. The speciation of uranium in simulated bile is shown in Figure 5-7 and summarized in Table 5-1.

(a)

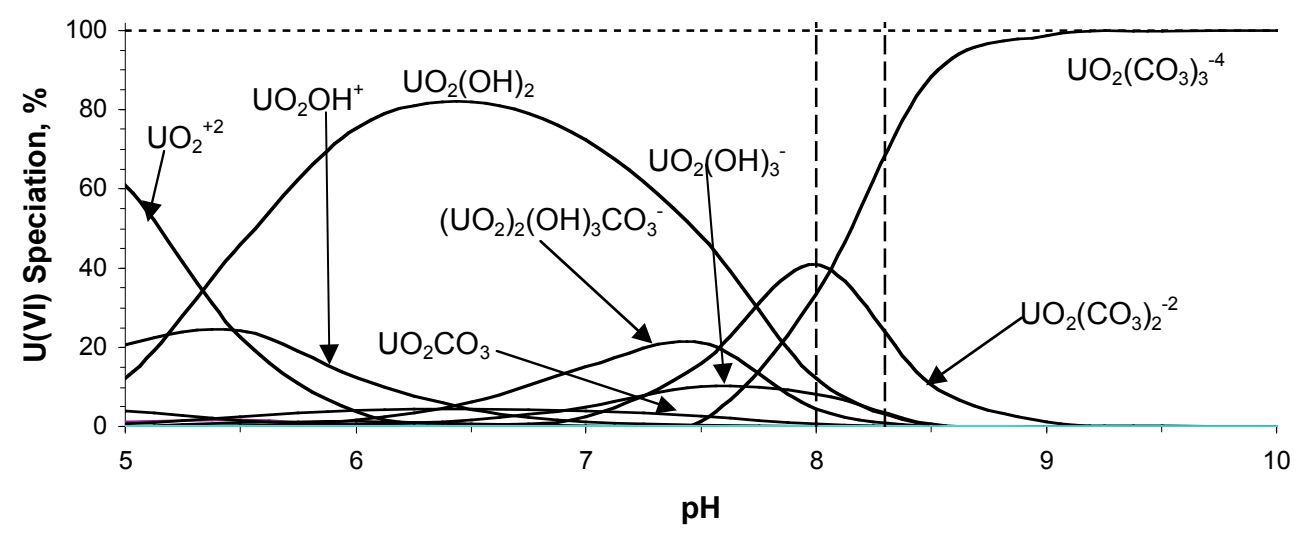

(b)

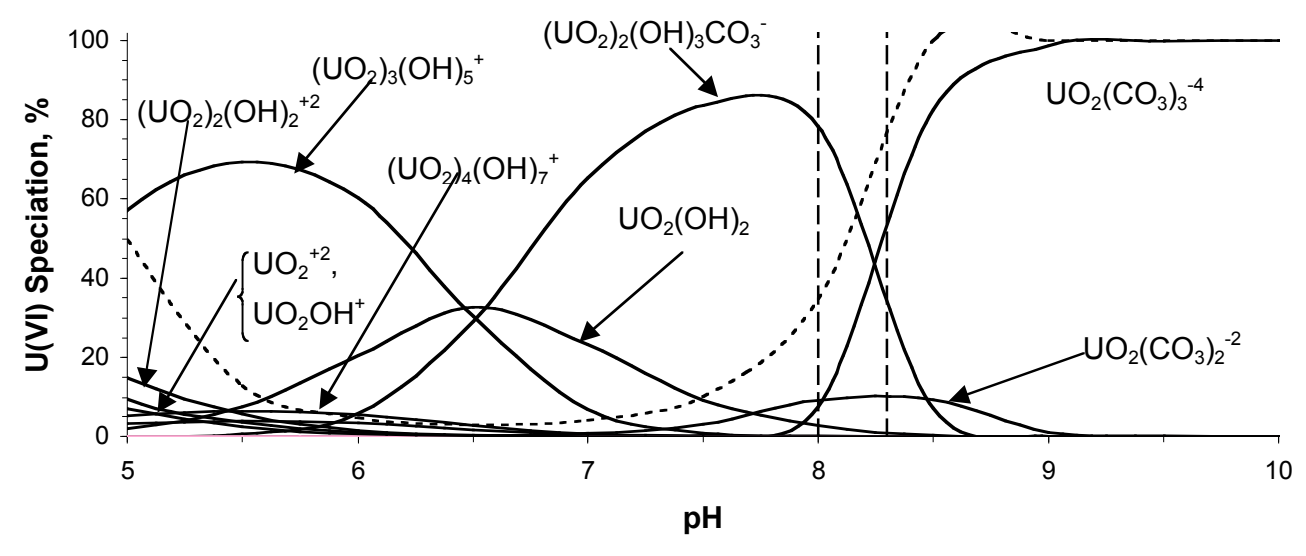

Figure 5-6. Uranium speciation and solubility with varying $\mathrm{pH}$ in simulated pancreatic fluid at $[U]=(a) 1 \mu M$ and (b) $1 \mathrm{mM}$. A dashed curved line depicts solubility. 
Dominating species include phosphate, carbonate and hydroxide complexes, and solubility is limited by the formation of a $\mathrm{CaUO}_{4}$ precipitate. Predictions also show that in simulated elemental bile, sodium-autunite precipitates from $\mathrm{pH} 4.5$ to $\mathrm{pH} 8.5$, $\mathrm{UO}_{2}(\mathrm{OH})_{2}$ precipitates from $\mathrm{pH} 5$ to $\mathrm{pH} 8.5$, and $\mathrm{CaUO}_{4}$ precipitates from $\mathrm{pH} 7.0$ to 9.5.

Although other biological components of bile (e.g. steroid acids, bilirubin) are not considered in this elemental model (to the most part) due to lack of thermodynamic data, their presence in bile may well impact the speciation and solubility of uranium. More research is needed to understand the chemistry uranium in the presence of bile, steroid acids and bilirubin. Both pancreatic fluid and bile are not considered key components in uranium toxicity.

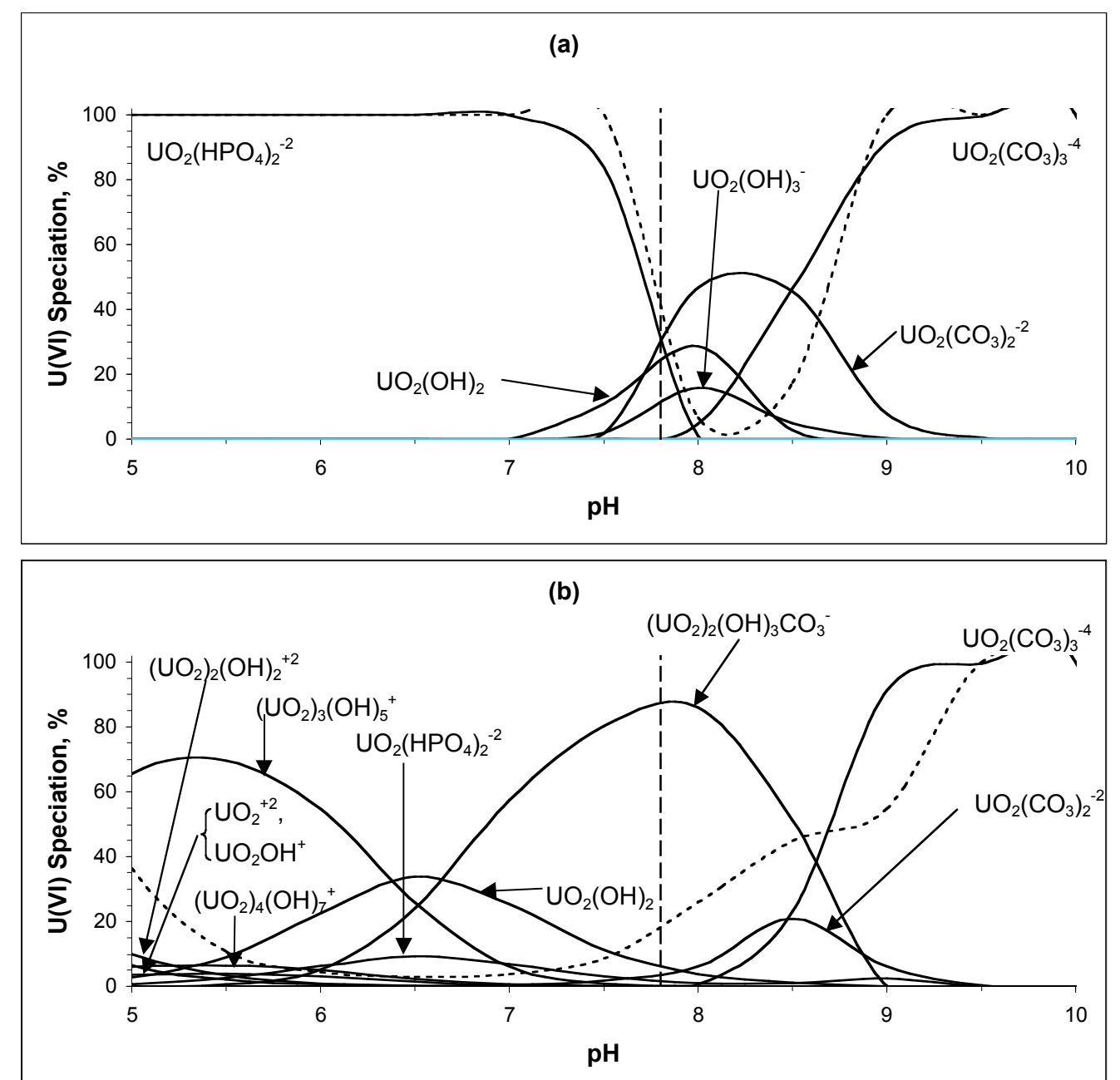

Figure 5-7. Uranium speciation and solubility with varying $p H$ in simulated bile at $[U]=$ (a) $1 \mu M$ and (b) $1 \mathrm{mM}$. A dashed curved line depicts solubility.

\subsubsection{Gastric Juice}

The phosphate complexation of uranium is also important in the speciation of uranium in simulated gastric juice (Table 5-1, Figure 5-8). Uranium(VI) is predicted to be mostly present as the uncomplexed uranyl ion, but some phosphate complexation does occur 
even at this low $\mathrm{pH}$. The solubility of uranium(VI) in simulated gastric juice is limited by the formation of a solid $\left(\mathrm{UO}_{2}\right)_{3}\left(\mathrm{PO}_{4}\right)_{2}$ salt between $\mathrm{pH} 1$ and $\mathrm{pH} 3$, and by sodiumautunite between $\mathrm{pH} 3$ and $\mathrm{pH} 9$.

(a)

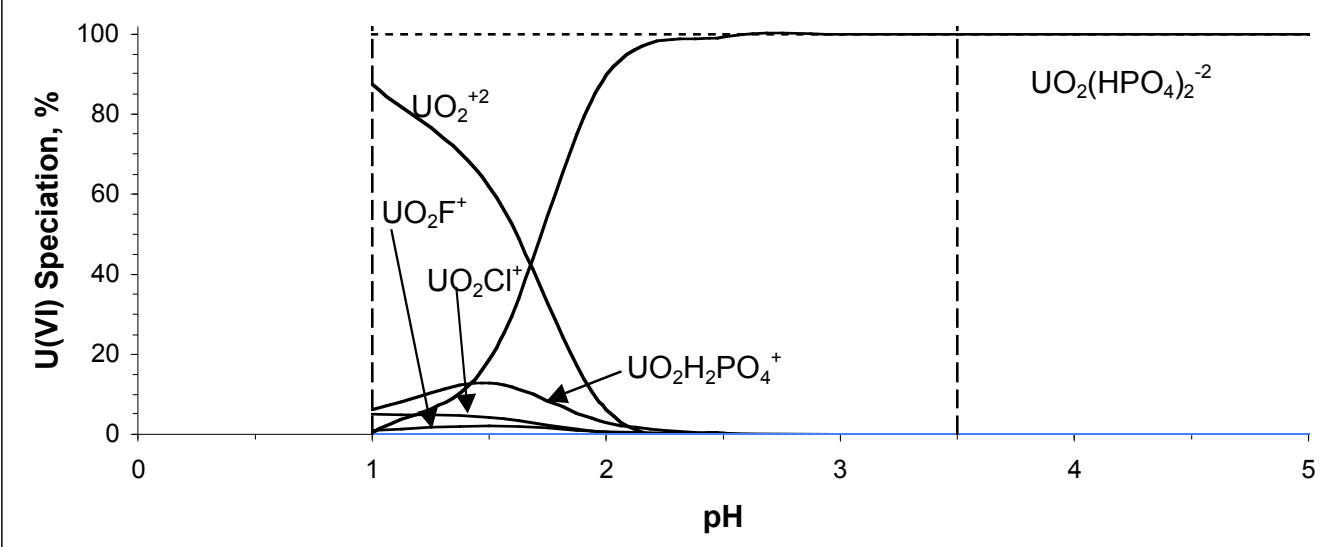

(b)

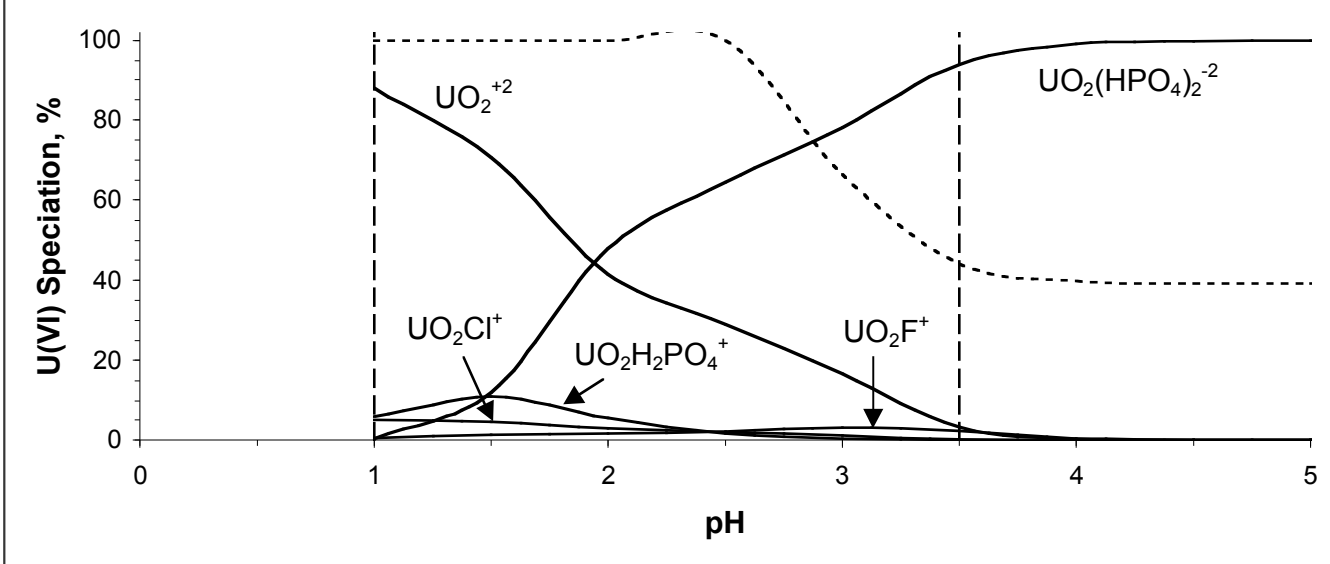

Figure 5-8. Uranium speciation and solubility with varying $\mathrm{pH}$ in simulated gastric juice at $[U]=($ a) $1 \mu M$ and (b) $1 \mathrm{mM}$. A dashed curved line depicts solubility.

The absorption of uranium in the gastrointestinal tract has been the study of much investigation, and has been summarized by several researchers (60-62). Their conclusions are that uranium absorption is small, typically between $0.02-6 \%(61,62)$, with a reasonable central estimate of $1-2 \%(60,62)$. The variation in absorption factors depends upon the parameters of each study (human vs. animal, chemical form, exposure route, age, diet etc). Furthermore, Leggett (62) summarizes the results of others and concludes that absorption generally decreases with the solubility of the uranium compound, such that soluble ionic uranium salts such as uranyl nitrate, uranyl fluoride and ammonium diuranate are more absorbed than insoluble compounds such as uranium(IV) chloride, oxides and fluoride. We believe that in addition to the solubility of these compounds, GI absorption is dependent on the $\mathrm{pH}$ and chemical composition of gastric juice, and the 
formation (and thus solubility) of uranyl phosphate salt. Absorption of aqueous uranium species into the GI wall is modeled here in the form of uranyl phosphate and uncomplexed uranyl ions.

\subsubsection{Urine}

Model speciation of uranium in simulated urine shows uranium bound completely as $\mathrm{UO}_{2}\left(\mathrm{HPO}_{4}\right)_{2}^{-2}$ throughout the $\mathrm{pH}$ range (Table 5-1). As with intracellular fluid models, solubility is largely due to the high phosphate concentration with respect to uranium, and the high affinity of uranyl-phosphate ions. The uranium(VI) solubility limiting phase in simulated urine is predicted to be sodium-autunite. At higher $\mathrm{pH}$ values (above $\mathrm{pH} 9$ ) the phosphate complex begins to diminish while the tricarbonate species begins to dominate the uranium speciation.

The $\mathrm{pH}$ and carbonate concentration greatly affect the transfer of uranium from the plasma to the urine $(5,17,63)$. Recall that in plasma, carbonate complexation does not dominate uranium speciation until $\mathrm{pH}$ 6.5. The effects of $\mathrm{pH}$ are three-fold, namely the amphoteric nature of the uranyl ion (its ability to form anionic hydroxide species), the increased carbonate concentration with increasing $\mathrm{pH}$, and affinity for uranyl-carbonate affinity in more alkaline conditions. Hence, when carbonate concentrations are high, or $\mathrm{pH}$ is above 6.5, uranium absorption is low in the kidney tubules resulting in high urinary excretion $(5,17,63)$.

\begin{tabular}{|l|l|l|l|}
\hline Exposure Type & $\begin{array}{l}\text { Urinary Range, } \\
\boldsymbol{\mu g} / \mathbf{L}\end{array}$ & $\begin{array}{l}\text { Urinary Median, } \\
\boldsymbol{\mu g} / \mathbf{L}\end{array}$ & Reference \\
\hline Drinking water & $1-5650$ & 0.078 & 65 \\
\hline $\begin{array}{l}\text { Occupationally } \\
\text { exposed group (and } \\
\text { control group) }\end{array}$ & $\begin{array}{l}0.056-5.31 / \\
(0.003-0.049)\end{array}$ & $\begin{array}{l}0.240 \\
(0.009)\end{array}$ & 66 \\
\hline $\begin{array}{l}\text { Chronic inhalation } \\
\text { exposure }\end{array}$ & $9-57$ & 21 & 67 \\
\hline $\begin{array}{l}\text { Occupationally } \\
\text { exposure, lung }\end{array}$ & $5.5-26.0$ & - & 38 \\
\hline $\begin{array}{l}\text { Uranium miners, } \\
\text { Egypt }\end{array}$ & $8.4-29.2$ & - & 68 \\
\hline $\begin{array}{l}\text { Gulf War DU } \\
\text { exposure }\end{array}$ & $0.001-0.525$ & 0.012 & 10 \\
\hline $\begin{array}{l}\text { Gulf War DU } \\
\text { exposure }\end{array}$ & $0.001-3.515$ & 0.012 & 69 \\
\hline
\end{tabular}

Table 5-2. Examples of urinary uranium concentrations relating to a variety of exposures

Examples of uranium concentration in urine are reported in several units, typically $\mu \mathrm{g} / \mathrm{L}-$ urine, $\mu \mathrm{g} / \mathrm{g}$-creatinine, and $\mu \mathrm{g} / \mathrm{day}$. Excretion data are converted using $1.7 \mathrm{~g}$ creatinine/day and $1.4 \mathrm{~L}$-urine/day (64). A selection of urinary uranium concentrations reported in the literature (65-69) is shown in Table 5-2 for a variety of exposures. Results such as these can be applied as an indirect measure of worker exposure controls. Urine bioassays can also be used to measure excretion during medical follow-up of an accidental overexposure. Thus, chemical thermodynamics modeling provides potentially useful knowledge in the development of metal bioassay techniques in human samples as 
a measurement of human exposure (70). For example, the hand exposure previously mentioned in our study of the effect of sweat on uranium chemistry, resulted in urinary uranium concentrations of $34.3 \mu \mathrm{g} / \mathrm{L}$ and $32.6 \mu \mathrm{g} / \mathrm{L}$ for production and maintenance workers respectively. Urinary uranium concentrations as high as $3.5 \mathrm{mg} / \mathrm{L}$ have been observed (71) for workers exposed to highly soluble uranium compounds. As with GI absorption, uranium concentrations in urine vary depend upon the exposure type, age and $\operatorname{diet}(62)$.

\subsubsection{Lung / Airway Surface Fluid}

Chemical thermodynamic modeling of airway surface fluid (ASF) showed somewhat similar results for all the cases of interest. In each case, the dominating species was found to be $\mathrm{UO}_{2}\left(\mathrm{HPO}_{4}\right)_{2}^{-2}$ and the solubility was above the initial uranium model input concentrations (Table 5-1). However, as with previous examples, we were able to predict uranium(VI) solubilities in ASF by adding further uranium to the model calculations. The results predict that the solubility of uranium(VI) at $\mathrm{pH} 7.0 \mathrm{in}$ ASF is greatest in hypersecretory ASF $(9.1 \mathrm{mM})$, followed by post-anticholinergic ASF $(6.1 \mathrm{mM})$, normal ASF $(6.0 \mathrm{mM})$ and post-bezodiazepine ASF $(3.0 \mathrm{mM})$. This difference is due to the availability of phosphate in each airway surface fluid, and the subsequent precipitation of sodium-autunite. At $\mathrm{pH}$ values higher than 9.0, uranium speciation becomes increasingly dependent on carbonate complexation. Additional airway surface fluid models were available (such as sustained irritation ASF, acute airway infection ASF, cystic fibrosis ASF, and severe asthmatic ASF), but did not contain phosphate composition data and so are not reported here for reasons of consistency. Cooke (72) found that $\mathrm{UO}_{3}$ solubility in simulated lung fluid (73) was approximately $1.0 \mathrm{mM}$ at $37^{\circ} \mathrm{C}$. Recent work has also shown that rat alveolar exposure to uranium induces $\mathrm{TNF}_{\alpha}$ (cytokine) secretion and MAPK (protein kinase) activation, potentially leading to chronic inflammatory lung disorders (74). The $\mathrm{LC}_{50}$ for rat alveolar macrophages is $0.5 \mathrm{mM}$ (75).

A further alternative to ASF as a lung fluid model is that of simulated lung fluid (SLF) (76-78). Here, the composition of the fluid is similar to that of interstitial fluid, but includes citrate and acetate compounds to simulate protein components in the fluid. Uranium is known to form complexes with both citrate and acetate and these effects can be observed in Figure 5-9. However, at the reference $\mathrm{pH}$ of simulated lung fluid ( $\mathrm{pH} 7.4$ ) citrate and acetate are not at a significant concentration to be able to compete with carbonate complexation (Table 5-1). The results are therefore similar to those observed in extracellular fluid (interstitial and plasma) models. However, the solubility of uranium(VI) in simulated lung fluid is $2.3 \mathrm{mM}$ and is somewhat higher than that of interstitial fluid $(0.93 \mathrm{mM})$. At lower $\mathrm{pH}$ regions, the uranium speciation can be explained in terms of a mixture of phosphate, carbonate and even citrate complexes. Recall, Scott (3) and Leggett (5) suggested that in the case of uranium(VI), about $60 \%$ is carried as a soluble bicarbonate complex with the remainder bound to plasma protein. Our results show that in order to recreate $40 \%$ protein binding, citrate concentrations need to be higher than those reported by Moss if an elemental simulated fluid is to be used. Indeed, Moss (76) stated that under the conditions studied, protein did not seem to be a significant sink for uranium. Alternatively, it may be that citrate is not a good analogue for protein binding of uranium. Kalkwarf (78) found that using citrate and 
acetate as previously described (76) failed to affect the dissolution rate of a hexavalent uranium ionic compound (ammonium diuranate) in simulated lung fluid. Our conclusion is therefore that citrate and acetate are not reasonable analogues to use for uranium protein interactions in thermodynamic modeling, and that more research and discussion are needed to determine acceptable analogues.

(a)

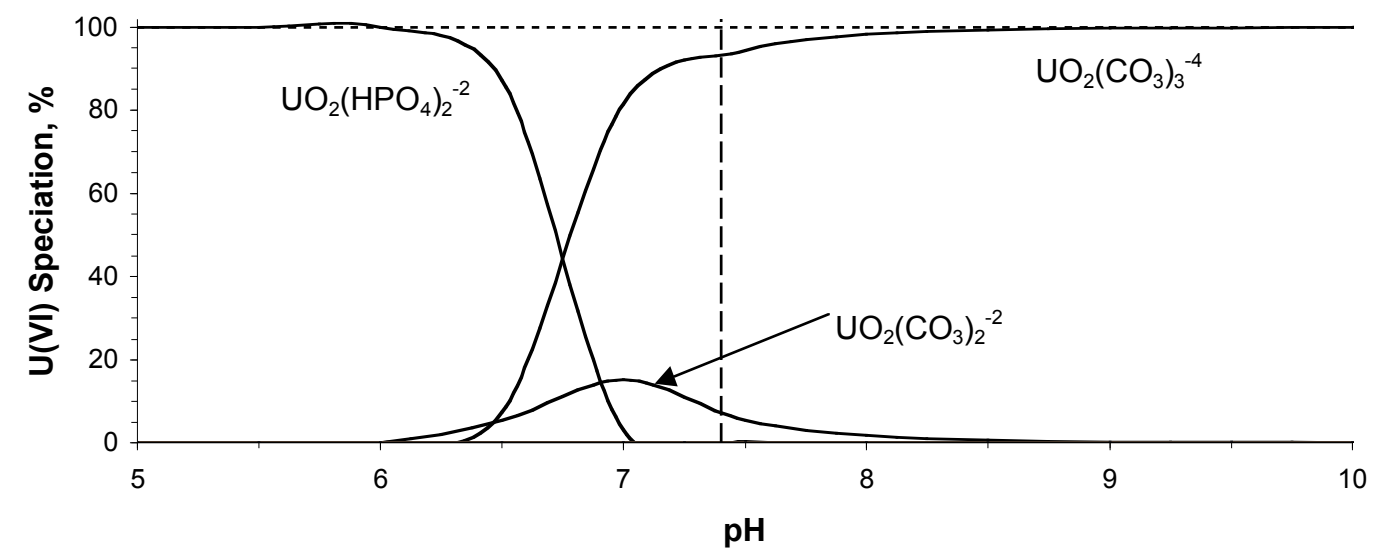

(b)

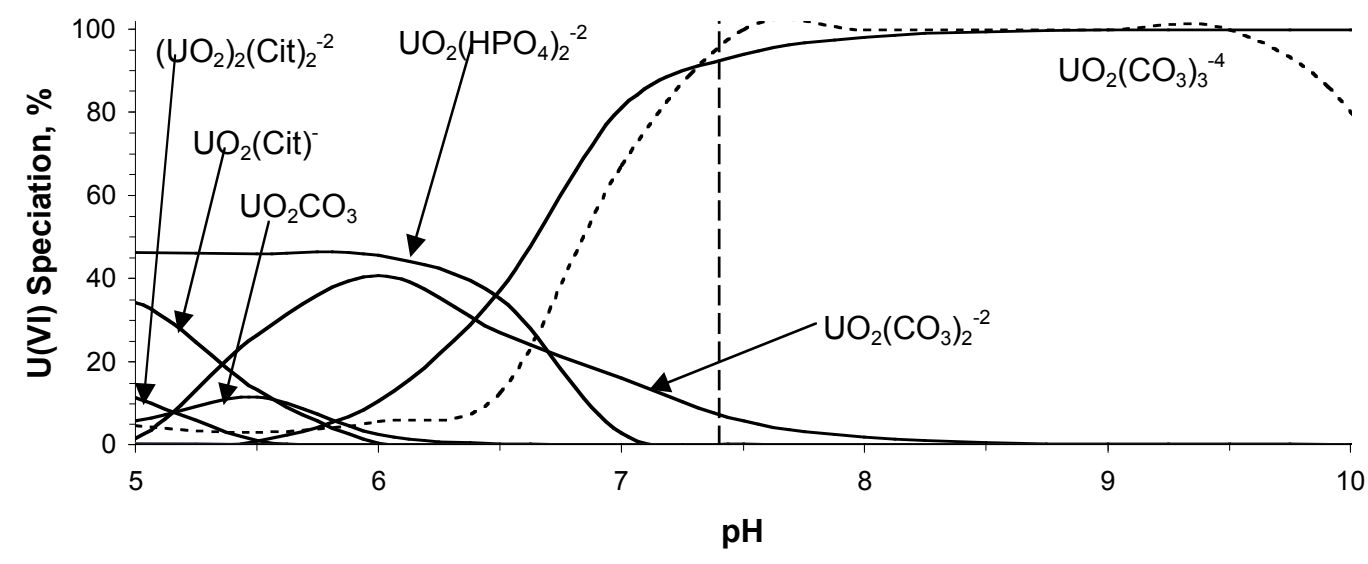

Figure 5-9. Uranium speciation and solubility with varying $\mathrm{pH}$ in simulated lung fluid at $[U]=(a) 1 \mu M$ and (b) $1 m M$. A dashed curved line depicts solubility.

\subsection{Model Assumptions and Limitations}

The modeling presented in this work requires several assumptions and is subject to the following limitations:

(1) A thermodynamic equilibrium state is assumed. This assumption is valid because reaction kinetics of ion interactions in homogeneous fluids are almost instantaneous and based on the probability of ions existing in the same space at the same time. Additionally, kinetics depends on the rate of electron transfer to form a chemical bond (electrostatic or covalent) followed by the subsequent structural rearrangement of atoms in space to yield 
the most stable structure. However, much larger kinetic effects are seen in heterogeneous fluids, especially in the reaction between solids and liquids. Depending on the mineral, and the chemical and physical environment, such reactions can occur over time periods ranging from seconds to thousands of years. Reaction kinetics is not considered in this model.

(2) Typical elemental biological fluids are assumed. The variation in human fluid composition and its effect on in-vivo uranium chemistry is acknowledged. For example, decreasing the partial pressure of $\mathrm{CO}_{2}$ in extracellular fluid models would lead to a decrease in uranium carbonate species and a decrease in sodium autunite solubility. Age, prolonged illness, prescribed medications, environment, diet and lifestyle all influence fluid composition in the human populations. While some biological fluids are subject to rapid changes that would affect uranium chemistry in-vivo, homeostasis in both fluids and cells minimizes such changes.

(3) Elemental fluid compositions are assumed. The modeling reported in this article is limited to the elemental (simple ion) speciation and solubility. No thermodynamic assessment of uranium binding to proteins or intracellular constituents is made (with the exception of citrate and acetate as potential analogues). Transferrin is known to bind to actinides $(26,48,79)$ and a conditional formation constant $\left(\log \mathrm{K}_{\mathrm{f}}=16\right)$ has been proposed (27) as a first estimation for a $\left(\mathrm{UO}_{2}\right)_{2} \mathrm{Tf}$ species. While the authors acknowledge the research by Scapolan and others, and the possible presence of uranyl-transferrin in some biological fluids, the complex was not included in the model for the following reasons: (a) the charge on the uranyl-transferrin species was not determined and therefore its use would be incongruous with chemical thermodynamic modeling; (b) the complex has not yet been critically reviewed by sources used in this model (33-35); and (c) transferrin forms a stronger complex with iron $\left(\log \mathrm{K}_{\mathrm{f}}=21\right.$ at $\left.\mathrm{pH} 7.4(80)\right)$ and in certain chemical environments would therefore bind preferentially with iron rather than uranium. In a biological system, there is typically more available transferrin compared to iron, thus leaving an excess of available binding sites for potential binding with uranium. Furthermore, the upper and lower limits of the $\mathrm{pH}$ range of the biological fluids studied here are in some cases much different to the normal biological $\mathrm{pH}$ of 7.4. The $\mathrm{pK}_{\mathrm{a}}$ of transferrin differs depending upon the nature of the binding site. The apparent $\mathrm{pK}_{\mathrm{a}}$ of transferrin is approximately 7.4, but iron binding occurs at different sites on the transferrin molecule at $\mathrm{pH} 6.0$ and $\mathrm{pH} 8.5$ (81). We believe that at lower $\mathrm{pH}$, the affinity of transferrin for both iron and uranium would be less because of increased protonation of the functional groups on the transferrin protein molecule. At higher $\mathrm{pH}$, we believe that the hydroxide and carbonate complexation of uranium will predominate over transferrin complexation.

Thus, the models presented in this work are the best possible given the lack of complete thermodynamic data on protein interaction. We strongly recommend the further characterization of thermodynamic data for uranium-protein interactions and their inclusion in future uranium / biological fluid thermodynamic models. 


\subsection{Conclusions}

Uranium speciation and solubility in simulated biological fluids is dependant on the $\mathrm{pH}$, uranium concentration, fluid composition and ionic strength of each system. In addition, uranium solubility is several times higher inside a cell than outside a cell, depending upon the phosphate concentration and $\mathrm{pH}$ of intracellular fluid. The solubility of uranium is controlled by potassium-autunite in intracellular fluid, and sodium-autunite in extracellular fluid. Carbonate, hydroxide and phosphate complexes are the dominant species in many of the biological fluids. The range of phosphate concentrations in airway surface fluids dictates the uranium solubility through the formation of insoluble autunites. The phosphate concentrations are highly dependant on the lung condition of the patient. Simulation of lung fluid showed that protein analogs such as citrate and acetate showed no significant uranium binding at the correct $\mathrm{pH}$ for such a fluid.

Further work will be performed to experimentally verify the data obtained by thermodynamic modeling. The authors believe that a more complete characterization of uranium interactions with albumin, transferrin and erythrocytes is required before they can be included in a critically reviewed chemical thermodynamic model. We recognize the uranium-transferrin studies by Scapolan et al and encourage their continued research. As the underlying thermodynamic biochemistry of uranium is better characterized, these biological components can be added to a model such as that presented here. When combined with experimental data, such resulting models can be applied to the understanding of uranium metabolism and toxicology, biological monitoring and therapeutic treatment.

In conclusion, chemical thermodynamic models can make unique and valuable contributions to the understanding of uranium speciation, solubility and distribution in the body. A better understanding of the impact of uranium exposures on human health and improved bioassays for uranium overexposure can result from further combination of these models with results from experimental toxicology. These results are also important in the development of specific chelators to remove uranium body burden in heavily exposed persons.

\subsection{References}

(1) United Nations Scientific Committee on the Effects of Atomic Radiation (2000) The 2000 report to the General Assembly with scientific annexes (UNSCEAR, United Nations, N. Y.).

(2) The Royal Society (2002) The health effects of depleted uranium munitions. Royal Society Document $6 / 02$.

(3) Scott, L. M. (1973) Environmental monitoring and personnel protection in uranium processing, p. 271. Published in Handbook of Experimental Pharmacology - Uranium, plutonium, Transplutonic Elements, Ed, Eds (ed. Hodge, H. C., Stannard, J. N. and Hursh, J. B., Springer Verlag, N.Y.).

(4) Hursh J. B. and Spoor, N. L. (1973) Data on man, page 197. Published in Handbook of Experimental Pharmacology - Uranium, plutonium, Transplutonic Elements (ed. Hodge, H. C., Stannard, J. N. and Hursh, J. B., Springer Verlag, N.Y.).

(5) Leggett, R. W (1989) The behavior and chemical toxicity of U in the kidney: a reassessment. Health Phys. 57, (3) 365-383.

(6) Thun, M. J., Baker, D. B., Steenland, K. Smith, A.B, Halperin, W. and Berl, T. (1985) Renal toxicology in uranium mill workers. Scand. J. Work Environ. Health 11, (2) 83-90.

(7) Raabe, O. G. (2001) A short review of depleted uranium toxicity. Janes Defense Weekly, January 12 th. 
(8) Oppenheimer, A. (2004) Radiation in Iraq: Depleted Uranium, Janes Chem-BioWeb, March 31st. http://www4.janes.com/subscribe/jcbw/doc_view.jsp?K2DocKey=/content1/janesdata/guides/jcbw/jcbw01 71.htm@current\&Prod_Name=JCBW\&QueryText=. Viewed August 13, 2004.

(9) Moszynski, P. (2003) Royal Society warns of risks from depleted uranium. Brit. Med. J. $326,952$. (10) McDiarmid, M. A., Engelhardt, S. M. and Oliver, M. (2001) Urinary uranium concentrations in an enlarged Gulf War veteran cohort. Health Phys. 80, (3) 270-273.

(11) Toohey, R. E. (2003) Excretion of depleted uranium by Gulf war veterans. Radiat. Prot. Dosim., 105, 171-174.

(12) United States General Accounting Office (2000) Gulf war illness - understanding of health effects from depleted uranium evolving but safety training needed. US GAO Report GAO/NSIAD-00-70. (13) The National Academy of Sciences (2000) Gulf War and Health, volume 1: depleted uranium, pyridostigmine bromide, sarin and vaccines. (ed. Fulco, C. E., Liverman, C. T. and Sox, H. C., National Academy Press, Washington DC.

(14) Bleise, A., Danesi, P. R. and Burkart, W. (2003) Properties, use and health effects of depleted uranium (DU): a general overview. J. Environ. Rad., 64, 93-112.

(15) McNider, W. De B. (1916) The inhibition of toxicity of uranium nitrate by sodium carbonate and the protection of the kidney acutely nephropathic from uranium and from the toxic action of an anesthetic by sodium carbonate. J. Exp. Med. 23, 171-187.

(16) Bhattacharyya, M. H., Breitenstein, B., Metivier, H., Muggenburg, B. A., Stradling, G. N. and Volf, V. (1992) Guidebook for the treatment of accidental internal radionuclide contamination of workers. Radiat. Prot. Dosim. 41, 27-36.

(17) Dounce, A. L. and Lan, T. H. (1949) The action of uranium on enzymes and proteins. In Pharmacology and Toxicology of Uranium Compounds, 1st Ed (ed. Voegtlin, C. and Hodge, H. C., McGraw-Hill, NY).

(18) Stradling, G. N., Taylor, D. M., Henge-Napoli, M.-H., Wood, R and Silk, T. J. (2000) Treatment for actinide-bearing industrial dusts and aerosols. Radiat. Prot. Dosim. 87, 41-50.

(19) Basinger, M. A. and Jones, M. M. (1981) Tiron (sodium 4,5-dihydroxybenzene-1,3-disulfonate) as an antidote for acute uranium intoxication in mice. Chem. Pathol. Pharmacol. 34, 351-358.

(20) Ubios, A.M., Braun, E. M. and Cabrini, R. L. (1994) Lethality due to uranium poisoning is prevented by ethane-1-hydroxy-1,1-diphosphonate (EHDP). Health Phys. 66, 540-544.

(21) Domingo, J. L., Ortega, A., Llobet, J. M. and Corbella, J. (1990) Effectiveness of chelation therapy with time after acute uranium intoxication. Fundam. Appl. Toxicol. 14, 88-95.

(22) Durbin P. W., Kullgren B., Ebbe S. N., Xu J. D. and Raymond K. N. (2000) Chelating agents for uranium(VI): 2. Efficacy and toxicity of tetradentate catecholate and hydroxypyridinonate ligands in mice. Health Phys. 78, (5) 511-521.

(23) Sutton, M., Burastero, S. R., Mundy, C. and Quong, J. (2002) Modern chemistry techniques in the medical chelation of beryllium. The Pharmacologist 44, (2), S1, A174, 100.24.

(24) Gorden, A. E. V., Xu, J. and Raymond, K. N. (2003) Rational design of sequestering agents for plutonium and other actinides. Chem. Rev. 103, 4207-4282.

(25) Wood, R., Sharp, C., Gourmelon, P., Le Guen, B., Stradling G. N., Taylor, D. M. and Henge-Napoli, M.-H. (2000) Decorporation treatment - medical overview. Rad. Prot. Dosim. 87, 51-57.

(26) Paquet, F., Frelon, S., Cote, G. and Madic, C. (2003) The contribution of chemical speciation to internal dosimetry. Radiat. Prot. Dosim. 105, 179-184.

(27) Scapolan, S., Ansoborlo, E., Moulin, C. and Madic, C. (1998) Uranium(VI)-transferrin system studied by time-resolved laser-induced fluorescence. Radiat. Prot. Dosim. 79, 505-508.

(28) Carriere, M., Avoscan, L., Collins, R., Carrot, F., Khodja, H., Ansoborlo, E. and Gouget, B. (2004) Influence of uranium speciation on normal rat kidney (NRK-52E) proximal cell cytotoxicity. Chem. Res. Toxicol. 17, 444446-452.

(29) Sutton, M., Warwick, P., Hall, A. and Jones, C. (1999) Carbonate induced dissolution of uranium containing precipitates under cement leachate conditions. J. Environ. Monit. 1, 177-182.

(30) Sutton, M., Warwick, P. and Hall, A. (2003) Uranium(VI) interactions with OPC/PFA grout. J. Environ. Monit. 5, 922-928.

(31) Sutton, M. and Burastero, S. R. (2003) Beryllium chemical speciation in elemental biological fluids.

Chem. Res. Toxicol. 16, 1145-1154. 
(32) Allison, J. D., Novo-Gradac, K. J. and Brown, D. S. (1998) MINTEQA2 ver.4. - A Geochemical Assessment Model for Environmental Systems. Environmental Research Laboratory, Office of Research \& Development, United States Environmental Protection Agency (Athens, Georgia).

(33) Smith, R. M. and Martell, A. E. (1982) Critical Stability Constants, vol.5. (Plenum Press, N. Y.). (34) Motekaitis, R. J. (2001) NIST Standard Reference Database 46 ver.6. - NIST Critically Selected Stability Constants of Metal Complexes (ed. Martell, A. E. and Smith, R. M.).

(35) Grenthe, I., Fuger, J., Konings, R.J.M., Lemire, R.J., Muller, A.B., Nguyen-Trung, C., Wanner, H. (1992) Chemical Thermodynamics of Uranium, Nuclear Energy Agency (Elsevier, Holland). Updated, 2003

(36) Durakovic, A., Horan, P., Dietz, L. A. and Zimmerman, I. (2003) Estimate of the time zero lung burden of depleted uranium in Persian Gulf War veterans by the 24-hour urinary excretion and exponential decay analysis. Mil. Med. 168, (8) 600-605.

(37) Kathren, R. L, McInroy, J. F., Moore, R. H. and Dietert, S. E. (1989) Uranium in the tissues of an occupationally exposed individual. Health Phys. 57, (1) 17-21.

(38) Baes, C. F. and Mesmer, R. E. (1976) The hydrolysis of cations. pp 175-182 (Wilie, N.Y.)

(39) Allard, B. (1982) Solubilities of actinides in neutral or basic solutions. Published in Actinides in Perspective (ed Edelstein, N. M., Pergamon Press, N.Y.).

(40) Newton, T. W. and Sullivan, J. C. (1985) Actinide carbonate complexes in aqueous solution.

Published in Handbook on the Physics and Chemistry of the Actinides. (ed. Feeman, A. J. and Keller, C., Elsevier Science, Amsterdam)

(41) Silva, R. J. and Nitsche, H. (1995) Actinide environmental chemistry. Radiochim. Acta, 70/71, 377396.

(42) Lieser, K. H. (1995) Radionuclides in the geosphere: sources, mobility, reactions in natural waters and interactions with solids. Radiochim. Acta, 70/71, 355-375.

(43) Clark, D. L., Hobart, D. E and Neu, M. P (1995) Actinide carbonate complexes and their importance in actinide environmental chemistry. Chem. Rev. 95, 35-48.

(44) Henge-Napoli, M-H., Ansoborlo, E., Claraz, M., Berry, J. P., Cheynet, M. C. (1996) Role of alveolar macrophages in the dissolution of two different industrial uranium oxides. Cell Mol. Biol. 42, 413-420.

(45) Mirto, H., Henge-Napoli, M-H., Gibert, R., Ansoborlo, E., Fournier, M. and Cambar, J. (1999)

Intracellular behaviour of uranium(VI) on renal epithelial cell in culture (LLC-PK1): influence of uranium speciation. Toxicol. Lett. 104, 249-256.

(46) Tasat, D. R. and De Ray, B. M. (1987) Cytotoxic effect of uranium dioxide on rat alveolar macrophages. Environ. Res. 44, 71-81.

(47) Rothstein, A. (1949) Pharmacology and Toxicology of Uranium Compounds. (McGraw-Hill, N.Y.).

(48) Chevari, S., Likhner, D. (1968) Complex formation of natural uranium in blood. Med. Radiol. 13, 5357.

(49) Simmons, C. F., Rennke, H. G. and Humes, H. D. (1981) Acute renal failure induced by

diethylaminoethyl dextran: importance of cationic charge. Kidney Int. 19, 424-430.

(50) Kirschbaum, B. B. (1982) Aggregation of renal brush border membranes by Concanavalin-A and heavy metals. Toxicol. Appl. Pharmacol. 64, 10-19.

(51) Kirschbaum, B. B. (1984) Interactions between renal brush border membranes and polyamines. J. Pharmacol. Exp. Ther. 229, 409-416.

(52) Boileau, L. J. R, Nieboer, E. and Richardson, D. H. S. (1985) Uranium accumulation in the lichen Cladonia rangiferina. Part II. Toxic effects of cationic, neutral and anionic forms of the uranyl ion. Can. J. Bot. 63, 390-397.

(53) Lana, C. (2000) Modelisation de la speciation de l'uranium dans le tractus gastrointestinal. Rapport de micro-these, Ecole de Chimie de Paris, p 67.

(54) Hamilton, E. I. (1971) The concentration and distribution of uranium in human skeletal tissues. Calc. Tiss. Res. 7, 150-162.

(55) Sairenji, E., Moriwaki, K., Shimizu, M., Noguchi, K., Anzai, I. and Ikeda, N. (1980) Determination of uranium content in dental porcelains by means of the fission track method and estimation of radiation dose to oral mucosa by radioactive elements. Health Phys. 38, 483-492.

(56) O'Riordan, M. C. and Hunt, G. J. (1974) Radioactive fluorescence in dental porcelains. U.K. National Radiological Protection Board, Report 25.

(57) Ubios, A. M., Marzorati, M. and Cabrini, R. L. (1997) Skin alteration induced by long-term exposure to uranium and their effects on permeability. Health Phys. 72, (5) 713-715. 
(58) Lopez, R., Diaz Sylvester, P. L., Ubios, A. M. and Cabrini, R. L. (2000) Percutaneous toxicity of uranyl nitrate: its effect in terms of exposure area and time. Health Phys. 78, (4) 434-437.

(59) Yu, R. C. and Sherwood, R. J. (1996) The relationships between urinary elimination, airborne concentration, and radioactive hand contamination for workers exposed to uranium. Am. Ind. Hyg. Assoc. J. 57, 615-620.

(60) Wrenn, M. E., Durbin, P. W., Howard, B., Lipsztein, J., Rundo, J., Still, E. T. and Willis, D. L. (1985) Metabolism of ingested U and Ra. Health Phys. 48, (5) 601-633.

(61) Harrison, J. D. (1991) The gastrointestinal absorption of the actinide elements. Sci. Total Environ. $100,43-60$.

(62) Leggett, R. W. and Harrison, J. D. (1995) Fractional absorption of ingested uranium in humans. Health Phys. 68, (4) 484-498.

(63) Yuile, C. L. (1973) Animal Experiments. Published in Handbook of Experimental Pharmacology Uranium, plutonium, Transplutonic Elements, Ed, Eds (ed. Hodge, H. C., Stannard, J. N. and Hursh, J. B., Springer Verlag, N.Y.).

(64) International Commission on Radiological Protection (1975) Report of the task group on reference man. ICPR Publication 23 (Pergamon Press, Oxford).

(65) Kurttio, P., Auvinen, A., Salonen, L., Saha, H., Pekkanen, J., Makelainen, I., Vaisanen, S. B., Penttila, I. M. and Komulainen, H. (2002) Renal effects of uranium in drinking water. Environ. Health Pers. 110, 337-342.

(66) Byrne, A. R. and Benedik, L. (1991) Uranium content of blood, urine and hair of exposed and nonexposed persons determined by radiochemical neutron activation analysis with emphasis on quality control. Sci. Total Environ. 107, 143-157.

(67) Quastel, M. R., Taniguchi, H., Overton, T. R. and Abbatt, J. D. (1970) Excretion and retention by humans of chronically inhaled uranium dioxide. Health Phys. 18, 233-244.

(68) Shawky, S., Amer, H. A., Hussein, M. I., El-Mahdy, Z. and Mustafa, M. (2002) Uranium bioassay and radioactive dist measurement at some uranium processing sites in Egypt - health effects. J. Environ. Monit. $4,588-591$.

(69) McDiarmid, M. A., Squibb, K. and Engelhardt, S. M. (2004) Biological monitoring for urinary uranium in Gulf War I veterans. Health Phys. 87, (1) 51-56.

(70) Karpas Z. (2001) Uranium bioassay - beyond urinalysis. Health Phys. 81, (4) 460-463.

(71) Eisenbud, M. (1975) Early occupational exposure experience with uranium processing. In Conference on occupational health: Experience with uranium. Arlington, VA, 28-30 April, ERDA 93, 8-24.

(72) Cooke, N. and Holt, F. B. (1974) The solubility of some uranium compounds in simulated lung fluid. Health Phys. 27, 67-77.

(73) Gamble, G. L. (1967) Chemical Anatomy, Physiology and Pathology of Extracellular Fluid. A Lecture Syllabus. pp 4-11, 8th Ed (Harvard University Press, Harvard).

(74) Gazin, V., Kerdine, S., Grillon, G., Pallardy, M. and Raoul, H. (2004) Uranium induces TNFa secretion and MAPK activation in a rat alveolar macrophage cell line. Toxicol. App. Pharmacol. 194, 4959.

(75) Lizon, C. and Fritsch, P. (1999) Chemical toxicity of some actinides and lanthanides towards alveolar macrophages: an in vitro study. Int. J. Radiat. Biol. 75, (11) 1459-1471.

(76) Moss, O. R. (1979) Simulants of lung interstitial fluid. Health Phys. 36, 447-448.

(77) Thein, M., Maitz, A. H., Austin, M. A., Rao, G. R. and Gur, D. (1982) Dissolution rates of airborne uranium in simulated lung fluid. Health Phys. 43, 587-590.

(78) Kalkwalf, D. R. (1983) Dissolution rates of uranium compounds in simulated lung fluid, Sci. Total Environ. 28, 405-414.

(79) Taylor, D. M. (1989) The biodistribution and toxicity of plutonium, americium and neptunium. Sci. Total Environ. 83, 217-225.

(80) Aisen, P., Liebman, A. and Zweier, J. (1978) Complex formation of natural uranium in blood. J. Biol. Chem. 253, 1930-1937.

(81) Chasteen, N. D. and Williams, J. (1981) The influence of $\mathrm{pH}$ on the equilibrium distribution of iron between the metal-binding sites of human transferrin. Biochem. J. 193, 717-727. 
6

\section{Conference Presentations, Paper and Reports Generated}


- Sutton, M. "Beryllium Chemistry" National Beryllium Health and Safety Committee Meeting, LLNL, CA. October 2001.

- Sutton, M., Burastero, S. R., Mundy, C. and Quong, J. "Examining Beryllium Chemistry with Modern Analytical Techniques" National Beryllium Research Symposium, National Institutes of Health (NIH), Bethesda MA. June 2002.

- $\quad$ Sutton, M., Mundy, C., Perkins, J. and Burastero, S. R. "Modern Chemistry Techniques in the Medical Chelation of Beryllium" 14th World Congress on Pharmacology, San Francisco, CA. July 2002.

- Sutton, M., Mundy, C., Perkins, J. and Burastero, S. R. "Modern Chemistry Techniques in the Medical Chelation of Beryllium" American Public Health Association (APHA) 130th Annual Meeting, Philadelphia PA. November 2002.

- Sutton, M. \& Burastero, S. R. "Beryllium Chemical Speciation in Elemental Human Biological Fluids" Presented at the International Beryllium Research Symposium, Denver, CO. January 2004. UCRL-PRES-201993.

- Sutton, M., Chiarappa-Zucca, M. L., Szechenyi, S. C., Perkins, J., Burastero, S. R. "Pilot Study of Beryllium-Specific Chelators in Mice" Presented at the International Beryllium Research Symposium, Denver, CO. January 2004. UCRL-ABS-201493, UCRL-POST-201640 and UCRL-PRES-201995.

- Sutton, M., Coronado, P. R., Szechenyi, S. C. "Beryllium Interactions with AerogelGAC Composites" Presented at the Beryllium Health and Safety Committee Meeting, DOE-HQ, DC, June 2003. UCRL-PRES-153508.

- Szechenyi, S. C, Sutton, M., Bibby, R. K., Guthrie, E. B., Esser, B. K. "ICP-MS Determination of Environmental Beryllium Collected on Air Filters and Aerogels" ICP-MS Winter Conference, Florida, January 2004.

- Sutton, M., Burastero, S. R., Mundy, C. and Quong, J. "Modern Chemistry Techniques in the Medical Chelation of Beryllium”, The Pharmacologist 2002, 44, 2, S1, A174, 100.24

- Sutton, M. and Burastero, S. R. "Beryllium Chemical Speciation in Elemental Human Biological Fluids”, Chem. Res. Toxicol. 2003, 16, 1145-1154.

- Sutton, M. and Burastero, S. R., "Uranium(VI) Solubility and Speciation in Simulated Elemental Biological Fluids", Chem. Res. Toxicol. 2004, 17, 1468-1480.

- Sutton, M., Coronado, P. R., Szechenyi, S. C., Gash, A. E, "Beryllium Interactions with Hydrophobic Silica Functionalized Aerogel / Granular Activated Carbon Material" LLNL Report UCRL-JRNL-204474. 


\section{Acknowledgements:}

This work was funded by Laboratory Directed Research and Development - Exploratory Research (LDRD-ER) at LLNL, for which we are very grateful to the support of the LDRD Committee. I would like to thank all the people who over the course of this research project have provided their experience, guidance and support, especially Mark Hoover at NIOSH CDC. This work was completely funded by LLNL-LDRD. Thank you to Bob Maxwell for NMR support, David Zalk for supplying Site 300 CFF beryllium particles and Rohit Shah for providing a BeO work area. Mark Sutton and Stephen Burastero were the Principal Investigators of this research. Brian Andresen provided a concise review and estimation of LD-50 values for our potential chelators. Marina Chiarappa-Zucca performed mouse studies and prepared samples for analysis. Sarah Chinn and April Sawvel performed ${ }^{9}$ Be NMR analysis on both liquid and solid samples. Paul Coronado produced aerogel/GAC material for this study, which was subsequently characterized by Alex Gash. Julie Perkins synthesized gram quantities of our chosen chelator and provided numerous reviews of our manuscripts. Scott Szechenyi performed ICP-MS analysis of hundreds of beryllium samples, ranging from simple aqueous solutions to complex aerogel matrices with interferences. Thank you to all those who have helped us along the way, from pre-proposal to mouse trials. Teardrop cover artwork by Rachel Sadd, DynamicMuse. 